(2) norden

\title{
Peatlands and Climate in a Ramsar context
}

A Nordic-Baltic Perspective

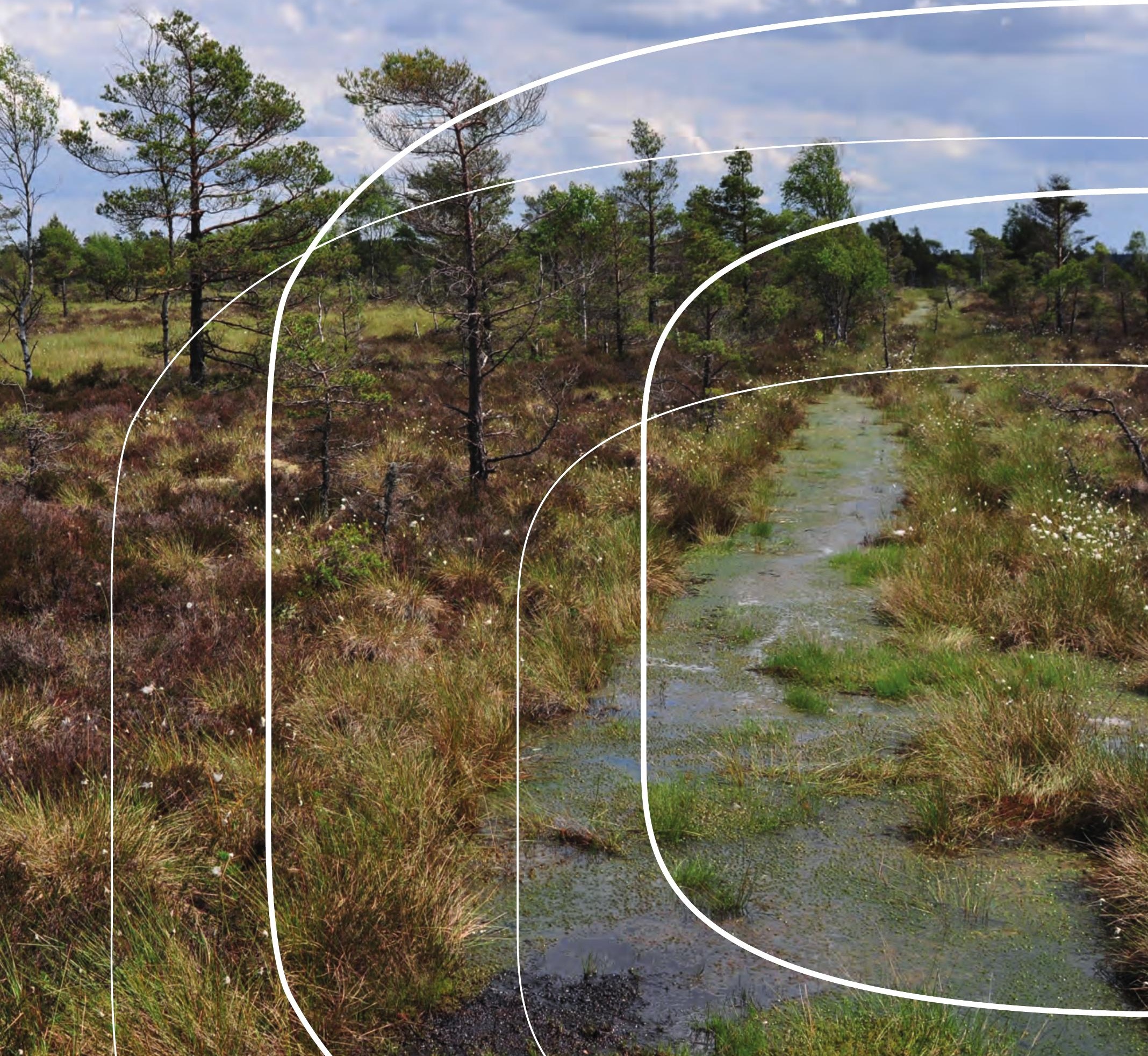



2 norden 



\section{Peatlands and Climate in a Ramsar context}

A Nordic-Baltic Perspective

Alexandra Barthelmes, John Couwenberg, Mette Risager,

Cosima Tegetmeyer and Hans Joosten

TemaNord 2015:544 
Peatlands and Climate in a Ramsar context

A Nordic-Baltic Perspective

Alexandra Barthelmes, John Couwenberg, Mette Risager, Cosima Tegetmeyer and Hans Joosten

ISBN 978-92-893-4195-0 (PRINT)

ISBN 978-92-893-4196-7 (PDF)

ISBN 978-92-893-4197-4 (EPUB)

http://dx.doi.org/10.6027/

TemaNord 2015:544

ISSN 0908-6692

(C) Nordic Council of Ministers 2015

Layout: Hanne Lebech

Cover photo: Hans Joosten

Print: Rosendahls-Schultz Grafisk

Copies: 30

Printed in Denmark
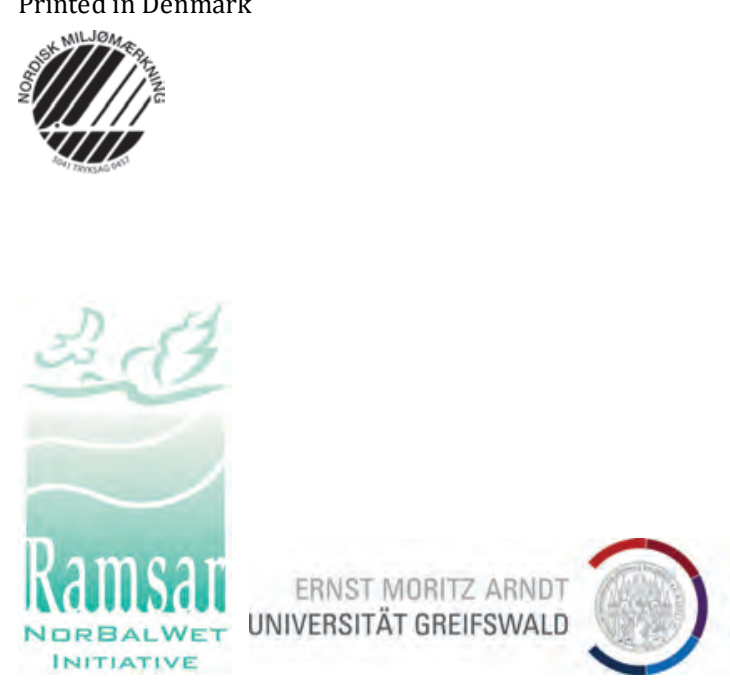

This publication has been published with financial support by the Nordic Council of Ministers. However, the contents of this publication do not necessarily reflect the views, policies or recommendations of the Nordic Council of Ministers.

\section{www.norden.org/nordpub}

\section{Nordic co-operation}

Nordic co-operation is one of the world's most extensive forms of regional collaboration, involving Denmark, Finland, Iceland, Norway, Sweden, and the Faroe Islands, Greenland, and Åland.

Nordic co-operation has firm traditions in politics, the economy, and culture. It plays an important role in European and international collaboration, and aims at creating a strong Nordic community in a strong Europe.

Nordic co-operation seeks to safeguard Nordic and regional interests and principles in the global community. Common Nordic values help the region solidify its position as one of the world's most innovative and competitive.

\section{Nordic Council of Ministers}

Ved Stranden 18

DK-1061 Copenhagen $\mathrm{K}$

Phone (+45) 33960200

www.norden.org 


\section{Contents}

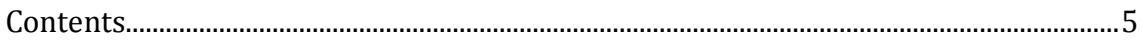

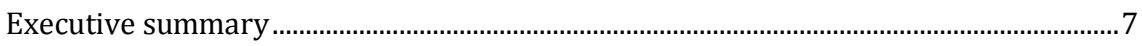

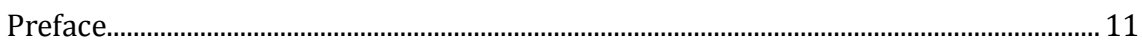

List of Acronyms ........................................................................................................ 13

1. Introduction: Ramsar, NorBalWet, peatlands and climate change ..........................15

2. Peatlands and climate in the Nordic-Baltic countries ............................................ 23

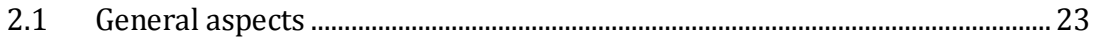

2.2 The role of peatlands in climate regulation and climate change

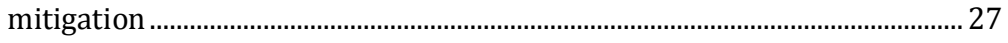

2.3 The climate effect of Nordic-Baltic peatlands ................................................... 39

3. Relation to other international conventions and policies............................................ 41

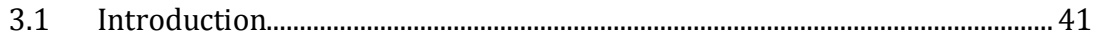

3.2 The UN Framework Convention on Climate Change (UNFCCC) ................... 41

3.3 The Convention on Biological Diversity (CBD) ................................................. 49

3.4 UNESCO World Heritage Convention ...................................................................51

3.5 Climate initiatives for peatlands from the UN Food and Agriculture

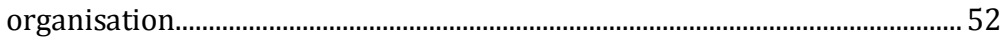

3.6 Climate initiatives for peatlands under the European Union ........................ 54

4. Climate change mitigation and adaptation as criteria for Ramsar site

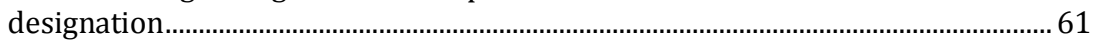

4.1 Introduction.................................................................................................... 61

4.2 The designation of Lille Vildmose................................................................. 61

4.3 Identifying Wetlands of International Importance for global

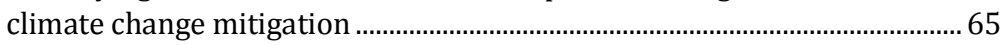

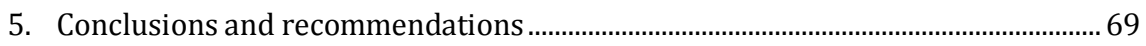

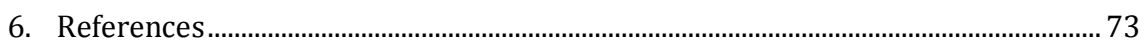

Resumé........................................................................................................................... 79

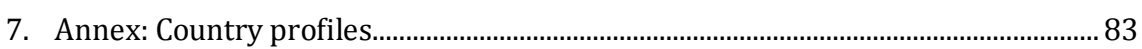

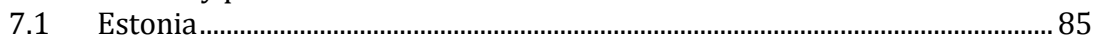

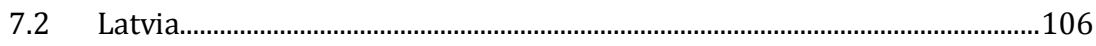

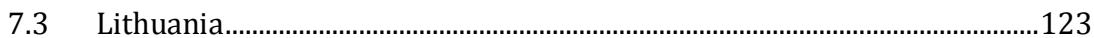

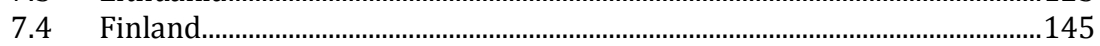

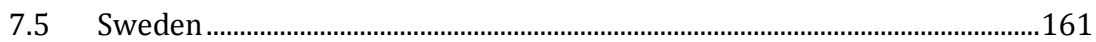

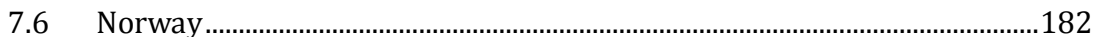

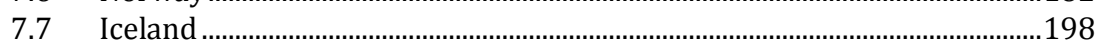

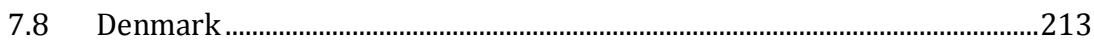

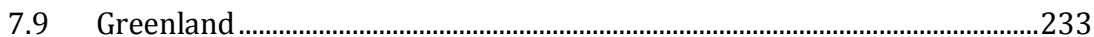





\section{Executive summary}

The Ramsar Convention on Wetlands provides a framework for national action and international cooperation for the conservation and wise use of wetlands and their resources. The Convention recognizes the importance of peatlands for climate change mitigation and has called upon countries "to minimize the degradation, as well as promote restoration, and improve management practices of those peatlands and other wetland types that are significant carbon stores, or have the ability to sequester carbon".

The Nordic Baltic Wetlands Initiative (NorBalWet) is a Ramsar regional initiative with as participants Denmark, Greenland, Faroe Islands, Estonia, Finland, Iceland, Latvia, Lithuania, Norway, Sweden and Oblasts from Northwestern Russia. In 2013 Denmark designated the raised bog of Lille Vildmose as a Ramsar site using a Ramsar criterion on climate regulation. Sweden submitted nine new Ramsar sites using that criterion in the same year. Subsequently the NorBalWet Initiative initiated a project to assess the importance of Nordic Baltic peatlands for climate regulation.

Next to a country by country assessment, this report discusses the challenges and opportunities to improve the management of peatlands in the NorBalWet countries for climate change mitigation. Peatlands are lands where high and stable water levels and consequent restricted decomposition of dead plant remains have led to the accumulation of carbon rich peat. Peatlands thus contain disproportionally more organic carbon than other terrestrial ecosystems, in the boreal zone, for example, 7 times more. When peatlands are drained, the peat is oxidized which results in the emission of substantial amounts of greenhouse gases.

The NorBalWet countries (excl. of Faroe Islands and Russia) hold with almost $250,000 \mathrm{~km}^{2}$ some $6 \%$ of the global extent of peatland. These peatlands play - certainly in their undrained state - an important role in the conservation of biodiversity and the provision of ecosystem services, including carbon storage.

Almost half (46\%) of the peatland area of the studied NorBalWet countries has been drained. These drained peatlands are responsible for over $75 \mathrm{Mt}$ of $\mathrm{CO}_{2}$-emissions annually, which constitutes a substantial part of the total $\mathrm{CO}_{2}$ budget. In the NorBalWet region peatland $\mathrm{CO}_{2}$-emissions are equal to $34 \%$ of the total $\mathrm{CO}_{2}$-emissions from all other sources combined 
(excl. land use). In Iceland and Latvia the peatland $\mathrm{CO}_{2}$-emissions are double as large as the total of other emissions, in Estonia, Lithuania and Finland 50\%, in Sweden and Norway 25 and 15\% respectively, whereas only in Denmark and Greenland they are less than $10 \%$ of the total of other $\mathrm{CO}_{2}$-emissions. These figures convincingly show that peatlands should play an important role in national climate policies.

Rewetting of drained peatlands leads to a substantial reduction of annual greenhouse gas emissions, as the new guidelines of the Intergovernmental Panel on Climate Change (IPCC) illustrate:

\begin{tabular}{|c|c|c|}
\hline \multirow[t]{2}{*}{ Initial drained land use } & \multicolumn{2}{|c|}{ Emission reduction after rewetting $\left(\left(\mathrm{t} \mathrm{CO}_{2}-\mathrm{e} \mathrm{ha}{ }^{-1} \mathrm{yr}^{-1}\right)\right)$} \\
\hline & Temperate zone & Boreal zone \\
\hline Forest Land & 6 & 2 \\
\hline Cropland: & 28 & 34 \\
\hline Grassland & 20 & 25 \\
\hline Peat extraction sites & 9 & 11 \\
\hline
\end{tabular}

Rewetting of peatland is consistent with a wide variety of policy initiatives and agreements of which the NorBalWet countries are part, including next to the Ramsar Convention - the UN Framework Convention on Climate Change (UNFCCC) and its Kyoto Protocol (KP), the Convention on Biological Diversity (CBD) and the Aichi Targets, the UNESCO World Heritage Convention and the Strategy for the Heritage Management of Wetlands of the European Archaeological Council, the climate initiatives of the UN Food and Agriculture organisation (FAO) and the European Union, the EU Habitats and Water Framework Directives, and the Convention on the Protection of the Marine Environment of the Baltic Sea Area (Helsinki Convention). Especially the "wise use" concept of the Ramsar Convention may provide an important bridge between these initiatives.

As a worldwide effective instrument for the conservation of wetlands, the Ramsar Convention should strengthen its efforts to conserve and restore the climate regulation function of the world's peatlands. As gases in the atmosphere are within a few days distributed across the globe, it is, however, for the climate inconsequential where on Earth emissions or emission reductions take place.

The global and comprehensive character of the peatland-climate relationship implies that the designation of peatlands as Wetlands of International Importance (Ramsar sites) will make a useful but limited contribution to this aim, as designation will only concern a selection of sites. Even the designation of the vast majority of the world's peatlands will not achieve a stabilization of the world's peat volume, as the peat losses from unprotected sites will - in case of maintenance and further expan- 
sion of drainage - completely overrule the carbon sequestration capacity of the protected sites. This is already the case in the current situation, where over $80 \%$ of the world's peatlands are still pristine.

The designation of peatlands as Wetlands of International Importance using the climate regulation function as an additional argument will contribute to the further recognition of the important role of peatlands for the world's climate. Using this argument as the exclusive criterion will, in contrast, give the wrong impression that individual peatlands, even the largest ones, contribute decisively to climate change mitigation, therewith hampering the necessary comprehensive conservation of all peatlands as carbon sinks and stores.

The safeguarding of the climate regulation function of peatlands will benefit more from an all-encompassing wise use approach for all peatlands worldwide. The Ramsar Convention should intensify its efforts in pursuing such comprehensive approach, especially in cooperation and in synergy with the many initiatives already being undertaken.

A crucial element of such strategy would be to use peatland Ramsar sites as centres for raising awareness, i.e. by illustrating the important role of peatlands for global climate regulation and for many other locally, nationally and internationally relevant ecosystem services and by providing on-the-ground examples of wise use and management. Such centres will be specifically effective for sites where natural, degraded and restored peatlands can be contrasted, where drivers and effects of non-wise use can be made easily apparent, where ample opportunity exists for communication, education and public awareness, and where a relevant audience is easily available. These attributes can support the arguments for designation of a peatland (complex) as a Wetland of International Importance on top of the use of biodiversity criteria. 



\section{Preface}

New knowledge reveals that one of the most efficient means to mitigate emissions of greenhouse gases to the atmosphere are the restoration of drained peatlands by reestablish former high water tables on organic soils. Examples of large scale peatland restoration for biodiversity are seen in the Nordic and Baltic region and it does make a very important contribution to mitigate greenhouse gases (GHG) as well.

This project on synergies between climate change mitigation and the restoration of peatlands has been conducted under the regional Ramsar initiative covering the Nordic and Baltic countries (NorBalWet). The report contains chapters on peatlands and their role in climate change mitigation and the role of the Ramsar Convention as well as individual country chapters.

The project was launched at a NorBalWet workshop on climate change mitigation and adaptation in Ilulissat, Greenland in September 2013 after receiving support from the Nordic Council of Ministers.

The first results were presented at a subsequent NorBalWet workshop on peatlands in Lille Vildmose, Denmark in September 2014 recognising peatlands" role in mitigating climate change and their restoration as a global opportunity. A resulting resolution was drafted on the importance of peatlands restoration and submitted by Denmark and supported by Finland to the Ramsar Conference of the Parties (COP12) in June 2015, as an output of the cooperation within this project.

Peatlands in the Nordic Baltic region and elsewhere in the world store large amounts of carbon and are at the same time important for conservation of biodiversity. Peatlands are space-effective carbon stocks but when drained carbon and nitrogen are released as greenhouse gases to the atmosphere and as nitrate to the surface water while methane especially may be released when rewetting.

Storage of carbondioxide in the sea contributes to ocean acidification while $\mathrm{CO}_{2}$ in the atmosphere contributes to global warming.However, land storage like in peatlands can be linked to positive effects in addition to carbon storage like biodiversity conservation, flood control and opportunities for recreation. 
This report has been authored by leading experts in the interface of peatlands and climate regulation Alexandra Barthelmes, John Couwenberg, Cosima Tegetmeyer and Hans Joosten from Griefswald Mire Centre at Greifswald University and Risager Consult and was made possible by financial support from the Climate and Air Pollution Group (KOL) and the Terrestrial Ecosystem Group (TEG) of the Nordic Council of Ministers. The NorBalWet Coordination Group and main country coordinators comprise the following:

- Estonia: Herdis Fridolin and Agu Leivits.

- Finland: Kristiina Niikkonen and Jari Ilmonen.

- Iceland: Gudridur Thorvardardottir.

- Latvia: Juris Jatnieks.

- Lithuania: Dalius Sungaila.

- Norway: Maja Stade Aarønæs.

- Sweden: Jenny Lonnstad.

- Denmark: Lars Dinesen, Mette Risager.

- Greenland: Andreas Lysholt Mathiesen and Inge Thaulow.

On behalf of the Regional Nordic Baltic Ramsar Initiative:

- Lars Dinesen.

- Danish Nature Agency.

- Chair NorBalWet / Project Leader. 


\section{List of Acronyms}

$\begin{array}{ll}\text { ANC } & \text { Areas of Natural Constraints } \\ \text { CAP } & \text { EU Common Agricultural Policy } \\ \text { CBD } & \text { Convention on Biological Diversity } \\ \text { CC-GAP } & \text { Coordinating Committee for Global Action on Peatlands } \\ \text { CM } & \text { Cropland Management } \\ \text { COP } & \text { Ramsar Conference of Parties } \\ \text { CRF } & \text { Common Reporting Format } \\ \text { DOC } & \text { Dissolved Organic Carbon } \\ \text { EEC } & \text { European Economic Community } \\ \text { ESD } & \text { Effort Sharing Decision } \\ \text { ETS } & \text { European Union Emission Trading Scheme } \\ \text { EU } & \text { European Union } \\ \text { FAO } & \text { UN's Food and Agriculture Organization } \\ \text { GAP } & \text { Global Action Plan for Peatland } \\ \text { GHG } & \text { Greenhouse gas } \\ \text { GM } & \text { Grazing land Management } \\ \text { GWP } & \text { Global Warming Potential } \\ \text { HELCOM } & \text { Baltic Marine Environment Protection Commission- } \\ & \text { Helsinki Commission } \\ \text { IMCG } & \text { International Mire Conservation Group } \\ \text { IUCN } & \text { International Union for Conservation of Nature } \\ \text { IPCC } & \text { Intergovernmental Panel on Climate Change } \\ \text { IPCC AR5 } & \text { IPCC fifth Assessment Report } \\ \text { IPS } & \text { International Peat Society } \\ \text { KP } & \text { Kyoto Protocol } \\ \text { LULUCF } & \text { Land Use, Land Use Change and Forestry } \\ \text { MICCA } & \text { Mitigation of Climate Change in Agriculture } \\ \text { MRV } & \text { Measuring, Reporting, Verification } \\ & \end{array}$




$\begin{array}{ll}\text { NAMA's } & \text { UNFCCC Nationally Appropriate Mitigation Actions } \\ \text { NFI } & \text { National Forest Inventory } \\ \text { NGO } & \text { Non Governmental Organization } \\ \text { NIR } & \text { National Inventory Report } \\ \text { NIS } & \text { National Inventory Submission } \\ \text { NorBalWet } & \text { Nordic Baltic Wetland Initiative } \\ \text { PRC } & \text { Peatland Rewetting and Conservation } \\ \text { REDD+ } & \text { UN Reducing Emissions from Deforestation and Forest } \\ & \text { Degradation } \\ \text { RIS } & \text { Ramsar Information Sheet } \\ \text { SBSTA } & \text { UNFCCC's Subsidiary Body for Scientific and Technological } \\ & \text { Advice } \\ \text { STRP } & \text { Ramsar Scientific and Technical Review Panel } \\ \text { UNFCCC } & \text { United Nations Framework Convention on ClimateChange } \\ \text { UNESCO } & \text { United Nations Educational, Scientific and Cultural } \\ \text { VCS } & \text { Organization } \\ \text { WDR } & \text { Verified Carbon Standard } \\ \text { WFD } & \text { Wetland, Drainage and Rewetting } \\ \text { WI } & \text { EU Water Frame Directive } \\ & \text { Wetlands International }\end{array}$




\section{Introduction: Ramsar, NorBalWet, peatlands and climate change}

The Convention on Wetlands, called the Ramsar Convention, is an intergovernmental treaty that provides a framework for national action and international cooperation for the conservation and wise use of wetlands and their resources. The treaty was signed in the Iranian city of Ramsar, which gave the Convention its popular name. Ramsar is situated in the midst of extensive peatlands with peat even occurring directly in front of the hotel where the founding meeting had taken place (fig. 1.1).

Fig.1.1: Dr. Elias Ramezani (University of Urmia, Iran) proudly presenting Ramsar peat in the park of the hotel in Ramsar (Iran) where in 1971 the Convention on Wetlands (Ramsar-Convention) was signed

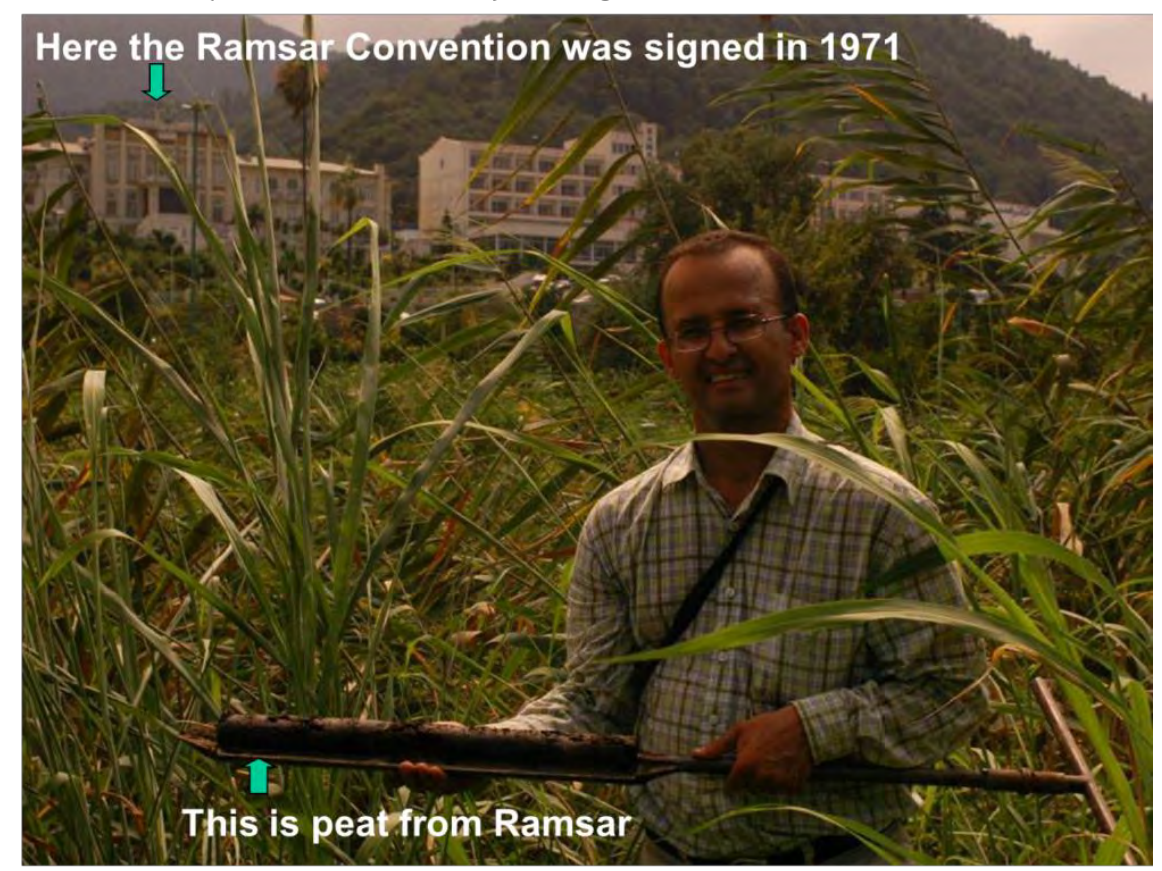

Photo: Hans Joosten 2008. 


\section{The Convention's work on peatlands}

In the beginning the Convention focused on waterbirds and other wetland types than mires, but has broadened its scope since then. At the $6^{\text {th }}$ Conference of the Parties (COP 6) in Brisbane, March 1996, a Special Intervention reported that whereas peatlands represent $50 \%$ of the world's terrestrial and freshwater wetlands, only 75 of the 778 Ramsar sites $(=9.6 \%)$ listed by December 1995 had peatland as their dominant habitat (Rubec 1996). In acreage (3 million out of 52 million ha $=6 \%$ ) the imbalance was even more obvious. Immediately the Convention took steps to correct the bias.

Brisbane Recommendation 6.1 "Conservation of peatlands" recognized peatlands as 'important wetland types hitherto under-represented in the work of the Convention'" with "peatland resources and associated peat products" being "of significant environmental and economic value to many nations in all regions of the world." The Recommendation pointed at the "ongoing degradation and destruction of peatland systems in many areas of the world due to ... agricultural and urban development, forestry, energy development, and horticultural harvesting of peat" and called on Contracting Parties "to maintain or give priority to the inventory and evaluation of peatlands ... and ... to nominate additional peatland ecosystems as Ramsar sites". The Recommendation further urged "the development, adoption and implementation of regionally based peatland management guidelines", recommended "the expansion of international mechanisms for coordination and cooperation for peatland conservation initiatives and programmes" and encouraged support by Contracting Parties "for research programmes in particular on peatland functioning and on restoration of degraded peatland ecosystems; for international networks for peatland training and education, and dissemination of the results of research on peatlands to Contracting Parties."

COP 7 in San José (Costa Rica, May 1999) subsequently adopted Recommendation VII.1 "A global action plan for the wise use and management of peatlands." The annexed Draft Global Action Plan was the first Ramsar decision to acknowledge the importance of peatlands for climate change mitigation and underlined "the need to include all wetland carbon sinks and sequestration initiatives as key issues in the global discussion concerning the Kyoto Protocol under the United Nations Framework Convention on Climate Change."

COP 8 in Valencia (Spain, November 2002) subsequently adopted several peatland and climate relevant resolutions. Resolution VIII.3 "Climate Change and Wetlands: Impacts, Adaptation and Mitigation" expressed concern about "the recent degradation of peatlands through 
drainage and fire in many parts of the world and the associated impacts on greenhouse gas emissions". Furthermore it noticed "key gaps in current knowledge and information on... the ways in which wetlands can mitigate climate change impacts, notably the role of peatlands in carbon sequestration", and called upon all relevant countries "to minimize the degradation, as well as promote restoration, and improve management practices of those peatlands and other wetland types that are significant carbon stores, or have the ability to sequester carbon". The resolution encouraged Contracting Parties to use the available information on climate change and wetlands for developing national policies for the conservation and wise use of their wetlands, and to undertake studies of the role of wetlands in carbon storage and sequestration. Finally it urged Parties "to make every effort, when implementing UNFCCC and ... its Kyoto Protocol, ..., that this implementation does not lead to serious damage to the ecological character of their wetlands". The latter provision specifically focused on forest management, afforestation and reforestation activities that in the framework of the Kyoto Protocol were widely undertaken as a mitigation activity but could be harmful for peatlands and other wetlands.

Resolution VIII.17 "Guidelines for global action on peatlands (GAP)" recognized the importance of peatlands "for the storage of water and carbon, which constitute a function vital to the world's climate system" and pled "for cooperative research to further elucidate the role of peatlands in mitigating the impacts of global climate change". The Resolution furthermore requested the Ramsar Bureau "to establish a Coordinating Committee for Global Action on Peatlands" (CC-GAP) and asked this Coordinating Committee "to prepare an implementation plan for global action on peatlands".

In Valencia the International Mire Conservation Group and the International Peat Society also presented the book "Wise Use of Mires and Peatlands" with a thorough analysis of the role of mires and peatlands in the global climate (Joosten \& Clarke 2002).

At COP 9 in Kampala (Uganda, November 2005) CC-GAP organized a side event to present the booklet "Peatlands - do you care?". This booklet stated: "Peatlands are the single largest terrestrial store of carbon (storing more carbon than the vegetation of the whole world and equivalent to $75 \%$ of all carbon in the atmosphere) and one of the best long-term stores. Therefore their continued degradation will accelerate global climate change. ... So far, the value of peatlands as carbon stores has received limited attention in decisions of the UNFCCC despite the significant emission of carbon in recent years as a result of peatland degradation and fires. 
However it is anticipated that this will start to change with the increasing recognition given to peatlands by other global environment conventions as well as the Intergovernmental Panel on Climate Change and a range of governments who are parties to the UNFCCC."

COP 10 in Changwon (Republic of Korea, November 2008) took place shortly after the publication of the "Global Assessment on Peatlands, Biodiversity and Climate Change" (Parish et al. 2008). This report reviewed the latest scientific information and had been endorsed by the Convention on Biological Diversity in May 2008. The Ramsar National Reports revealed a remarkable progress related to peatlands. Whereas in their reports for COP 9 still 32 countries had stated that peatlands were not applicable to them, in 2008 only 20 countries still made this assertion (Minaeva \& Joosten 2009). In a special CC-GAP peatland side event, the increased focus on peat for energy in e.g. Finland, Sweden and Russia was a central theme as well as the worldwide increasing use of peatlands for oil/gas infrastructure, wind energy, hydro-electricity, cultivation of "biofuels," and resources for an ever growing world population. The Supporting Event "Biofuels, Agriculture and Wetlands" concluded that biofuels cultivated on drained peatlands are generally much worse for the climate than burning coal (cf. Couwenberg 2007).

Three COP 10 resolutions explicitly addressed peatlands. Resolution X.24 "Climate change and wetlands" recognized that since Ramsar COP8 (2002) significant progress had been made "with respect to peatland inventory and awareness of the carbon storage function of ... peatlands". The Resolution noted "that the Global Assessment on Peatlands, Biodiversity and Climate Change ... analysed much information on the importance of peatlands for biodiversity and mitigation of, and adaptation to, climate change and confirmed that peatlands are the most important carbon store in the terrestrial biosphere, storing twice as much carbon as the forest biomass of the world, and that degradation of peatlands has been contributing annual emissions equivalent to $10 \%$ of global fossil fuel emissions". The Resolution urged relevant Contracting Parties "to take urgent action, ..., to reduce the degradation, promote restoration, improve management practices of peatlands and other wetland types that are significant GHG sinks, and to encourage expansion of demonstration sites on peatland restoration and wise use management in relation to climate change mitigation and adaptation activities" and called on Ramsar Administrative Authorities "to provide expert guidance and support ... to their respective UNFCCC focal point, within the context of UNFCC Decision 1/CP.13, on the joint policies and measures that are aimed to reduce anthropogenic greenhouse gas 
emissions from wetlands such as peatlands". Finally the Resolution encouraged Contracting Parties "to utilize peatlands to showcase the Communication, Education, Participation and Awareness activities for implementation of the Convention in the context of efforts to reduce greenhouse gas emissions and mitigate and adapt to the impacts of climate change" and to undertake "studies of the role of wetlands in carbon storage and sequestration, in adaptation to climate change, including for flood mitigation and water supply, and in mitigating the impacts of sea level rise, and to make their findings available to the Convention, the UNFCCC and other relevant processes".

Resolution X.25 "Wetlands and biofuels" was much less clear with respect to peatlands. Whereas peatlands are increasingly used for cultivating biofuels (with catastrophic results both for the peatlands and the global climate...) some Parties systematically kept all reference to peatlands out of the texts. A proposal of Costa Rica to avoid biofuels from drained peatlands was not supported. On request of Malaysia the reference to the conversion of peatswamp forests to palm oil production as a major cause of greenhouse gas emissions in Southeast Asia was skipped...

Resolution X.26 "Wetlands and Extractive Industries" urged Contracting Parties to "directing extractive activities to already drained peatlands, in order to reduce the environmental impacts of extractive activities on pristine peatlands, in recognition of the role of peatland conservation in reducing greenhouse gas emissions".

Finally COP 11 in Bucharest (Romania, July 2012) further strengthened the attention to peatlands. Resolution XI.8 "Streamlining procedures for describing Ramsar Sites ..." mentioned the "capacity to sequester carbon from the atmosphere and store it for long periods of time" as one of the significant features of peatlands. The Resolution expressed (in Annex 2) that "special attention should be given to the designation of peatlands which have at least some of the following attributes: ...

- the presence of a peat-forming vegetation ...

- the capacity to act as a carbon store

- the presence of a carbon sequestration function".

Resolution XI.14 was after 2002 (Resolution VIII.3) and 2008 (Resolution X.24) the third Ramsar resolution on the "Climate Change and Wetlands". The Resolution welcomed "the significant progress made since Ramsar COP10 (2008) with respect to knowledge and awareness of the importance of the carbon sequestration and storage function of wetlands (including inter alia inland peatlands and coastal wetlands), including in 
the scientific understanding of greenhouse gas fluxes from wetlands and the drivers of greenhouse gas fluxes from land use, land use change, and forestry sources" and recognized "that the continuing degradation and loss of these wetlands releases large amounts of stored carbon". For the first time in Ramsar history the Resolution also recognized the role of the greenhouse gases methane and nitrous oxide in wetlands.

The Resolution expressed "that ... the importance of wetlands in managing greenhouse gas emissions could be more widely recognized by international and national climate change response strategies and mechanisms, and could benefit from improved communication about the current and potential climate change mitigation provided by wetlands". The Resolution furthermore mentioned the new activity "Wetland Drainage and Rewetting" adopted by the UNFCCC in 2011, by which Annex I Parties can account for anthropogenic greenhouse gas fluxes from organic soils (peatlands) for the second commitment period of the Kyoto Protocol (UNFCCC Decision 2/CMP.7) and the Peatland Rewetting and Conservation (PRC) option of the Verified Carbon Standard (VCS) for generating and trading in peatland carbon credits on the voluntary market. The Resolution recognized "that the continuing degradation and loss of some types of wetlands cause the release of large amounts of stored carbon and thus exacerbates climate change", whereas "climate change is likely to exacerbate this trend which will further reduce the mitigation and adaptation capacity of wetlands". "[S]ince the conservation and wise use of wetlands have the potential to halt this degradation", the Resolution continued, "the designation of Ramsar Sites, together with their effective management, as well as that of other wetlands, can in some regions play a vital role in carbon sequestration and storage and therefore in the mitigation of climate change".

The Resolution urged "those Contracting Parties that are also Annex I Parties to the Kyoto Protocol to consider the wise use of wetlands" when choosing Wetland Drainage and Rewetting for accounting of greenhouse gas emissions under a second commitment period of the Kyoto Protocol, and encouraged Parties and their representatives "to reach out to their counterparts in the UNFCCC, and its relevant subsidiary bodies, in order to initiate and foster greater information exchange on the actual and potential roles of wetland conservation, management, and restoration activities in implementing relevant strategies, as appropriate, in mitigating greenhouse gas emissions through enhancing carbon sequestration and storage in wetlands". 
Last but not least, the Resolution encouraged Contracting Parties and relevant organizations "to undertake studies of the role of the conservation and/or restoration of both forested and non-forested wetlands in relation to: i) climate change mitigation, including the role of wetlands in carbon storage and sequestration, greenhouse gas emissions from degrading wetlands, avoidance of greenhouse gas emissions through removals of wetland carbon sinks, and ii) adaptation to climate change, including water regulation at local and regional scales, such as flood risk reduction, water supply and storage, and reducing the impacts of sea level rise and extreme weather events".

\section{The NorBalWet and its work on peatlands including the climate perspective}

The Nordic Baltic Wetlands Initiative (NorBalWet) was established in Trondheim, Norway, in 2005 based on Ramsar Resolution VIII.30 on "Regional initiatives for the further implementation of the Convention". NorBalWet was formally recognized as a Ramsar regional initiative at the 40th Meeting of the Standing Committee of the Convention in 2009.

Regional initiatives are important for implementation of the Ramsar Convention, as they can build upon bio-geographic commonalities, shared wetland systems and wetland-dependent species, and solidly established common social and cultural links. NorBalWet serves as a communication network to exchange information and experiences, thereby enhancing multilateral and transboundary cooperation by embracing a problem-oriented and practical approach to improve wise use and conservation of wetlands, including the network of Ramsar sites and other protected areas.

Participants in NorBalWet are Denmark, Greenland, Faroe Islands, Estonia, Finland, Iceland, Latvia, Lithuania, Norway, Sweden and Oblasts from Northwestern Russia.

In 2013 NorBalWet member Denmark submitted the raised bog of Lille Vildmose as the first wetland site ever in the history of the Convention to take into account a Ramsar criterion on climate regulation. Sweden submitted nine new Ramsar sites where the criterion was applied the same year. 
Subsequently the Nordic-Baltic Wetlands Initiative initiated a project to assess the importance of Nordic Baltic peatlands for climate regulation. Restoration of peatlands is an important tool to implement the Convention. What kind of peatlands can be most efficiently conserved and restored from a climate perspective and which sites may be of interest for Ramsar designation based on the criterion for climate regulation has to be investigated.

This report discusses the challenges and opportunities to use an additional criterion on climate regulation for designating Ramsar sites under more general criteria of designation of representative, rare or unique wetlands of international importance. 


\section{Peatlands and climate in the Nordic-Baltic countries}

\subsection{General aspects}

\section{Terms}

International peatland terminology is acknowledged to be in a state of confusion (Joosten \& Clarke 2002). In order to communicate, however, concepts are needed and terms are required to define these concepts. The terms used in this document are for the purposes of this document and their definitions are not intended to pre-empt further discussion.

A wetland is an area that is inundated or saturated by water at a frequency and for sufficient duration to support emergent plants adapted for life in saturated soil conditions. The Ramsar Convention also includes all open fresh permanent or temporary waters (of un limited depth) and marine waters ("up to a depth of six metres at low tide") in its "wetland" concept.

A peatland is an area with a naturally accumulated layer of dead organic material (peat) at the surface. In most natural ecosystems the production of plant material is counterbalanced by its decomposition by bacteria and fungi. In those wetlands where the water level is stable and near the surface, the dead plant remains do not fully decay but accumulate as peat.

A wetland in which peat is actively accumulating is called a mire (Figure 1, Joosten and Clarke 2002). Where peat accumulation has continued for thousands of years, the land may be covered with layers of peat that are meters thick. 
Fig. 2.1: The relation between "peatland", "wetland," and "mire"

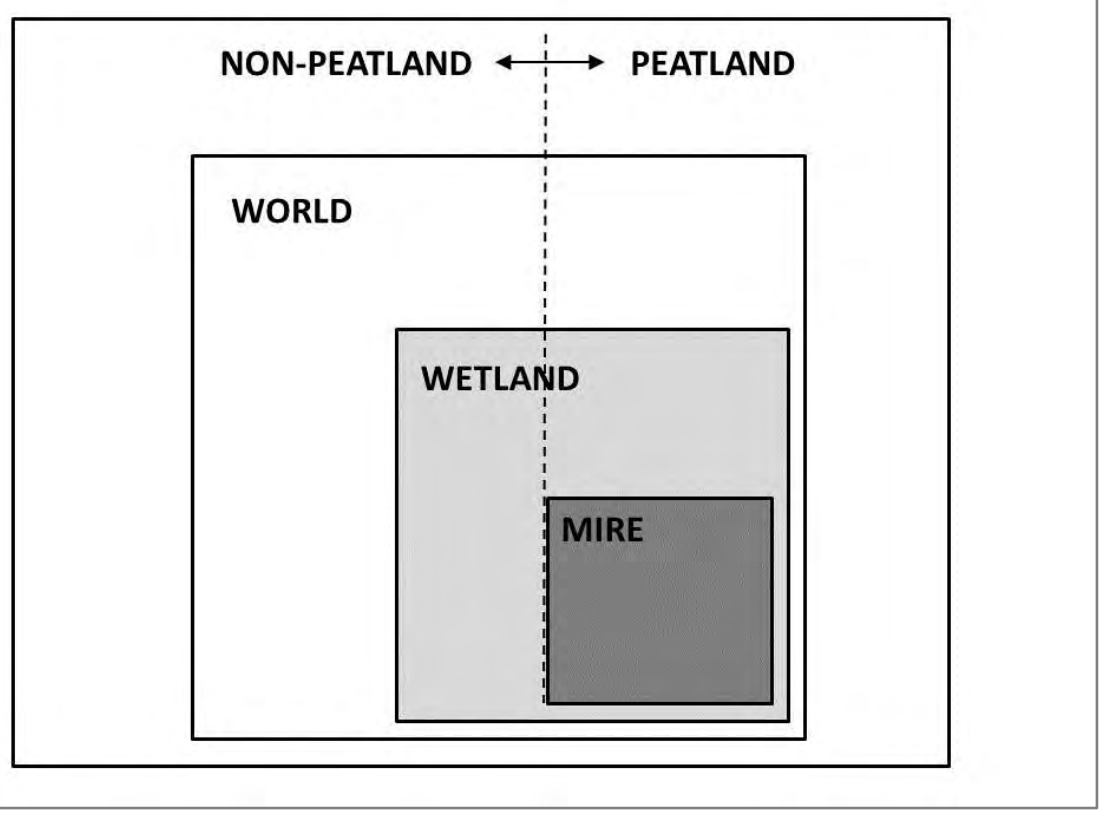

Joosten 2008.

Wetlands can occur both with and without peat and, therefore, may or may not be peatlands. In our concept, a mire is always a peatland and a wetland. Peatlands where peat accumulation has stopped, for example, as a result of drainage, are no longer mires. When drainage has been particularly severe, they are no longer wetlands (Joosten 2008).

\section{Distribution of peatlands and mire types}

Peat accumulates in areas of excess moisture where waterlogged conditions prevent the complete decomposition of dead plant material. The distribution and character of peatlands therefore strongly depend on climate. Peatlands cover large areas of the boreal zone where cool conditions limit evapotranspiration resulting in a positive water balance even in areas with relatively low precipitation. In the temperate zone, where evapotranspiration is higher, peatlands are found in oceanic regions with higher precipitation and cooler summers as well as in basins attracting groundwater from the surroundings. In the (sub-)arctic zone, peat accumulation is restricted by low temperatures and a short growing season, both limiting plant productivity. Here, permafrost results in fundamentally different types of peat formation. Climate thus governs where peatlands may occur, but rainfall and temperature and their seasonal variability also play an important role in determining the form and type of peatlands. The 
control of climate on peatland typology is expressed in peatland regions, each with their typical dominant type of peatland (e.g. Botch \& Masing 1983, Eurola et al. 1984, Jeschke et al. 2001, fig. 2.2).

Fig. 2.2: Mire regions (and subregions) in the NorBalWet area (excl. Greenland)

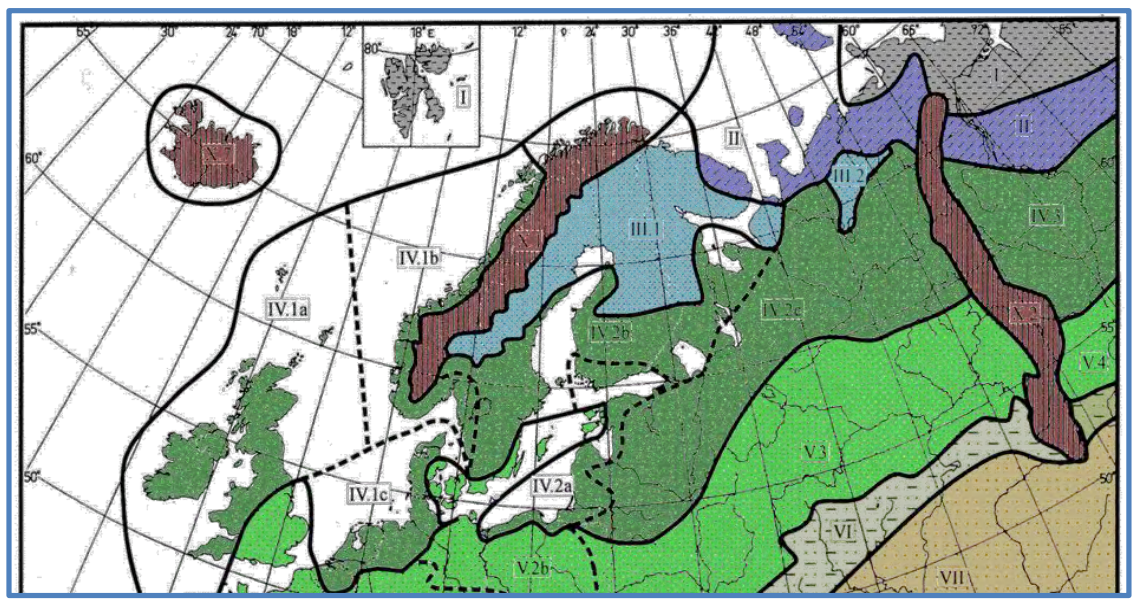

I. Region of arctic polygon mires.

II. Region of artic-subarctic palsa mires.

III. Region of boreal aapa mires.

IV. Region of raised bogs.

V. Region of fens of the zone of temperate deciduous forests.

VI. Region of fens of the submeridional forest steppe zone.

VII. Region of mires of the (sub-)meridional steppe and semi-desert zone.

$X$. Region of mountainous mires.

After Jeschke et al. 2001

The region of arctic polygon mires is restricted to areas of continuous permafrost with limited amounts of precipitation. Peat formation in these landscapes is typically linked to the development of ice wedges arranged in reticulate patterns and polygon mires consisting of elevated ridges enclosing wet depressions. Polygon peatlands cover large areas of the Siberian arctic lowlands, but in the NorBalWet area such mires are restricted to small occurrences on Svalbard, Novaya Zemlya and in the Russian Nenets Autonomous Okrug (fig. 2.2, I). Next to the typical polygon mires, also other mire types occur in the arctic region, including guano mires (incl. skua mounds), peat mounds ("arctic palsas"), basin fens, lake floodwater fens and snowpatch fens.

Whereas peatland development in the arctic region is driven by permafrost, the peatlands of the subarctic region rather induce permafrost themselves. Areas of discontinuous permafrost are largely confined to peatlands. The insulating properties of Sphagnum vegetation and peat 
delay thawing of ice during summer and lead to the development of peat plateaus (also known as "flat palsas" or "palsa plateaus", fig. 2.2, II). In sites with plentiful water, the formation of ice lenses in the Sphagnum peat results in large peat covered mounds of several metres height, so called "palsas". On high and steep palsa mounds the peat cover cracks allowing heat to penetrated the ice core, resulting in the collapse of the palsa and the formation of an open water (thermokarst) pond. Depending on depth and extent of the pond it may fill up with peat again or remain as an open water feature.

In more continental parts of the boreal region peatlands with distinct surface patterning of wet flarks and drier strings are found (fig. 2.2, III). In the north, so called aapa fens dominate, whereas concentric and excentric raised bogs are restricted to more southern regions. The maritime parts of the boreal region are characterised by relatively mild winters, cool summers and plentiful precipitation, resulting in the formation of blanket bogs as typical formation (fig. 2.2, IV 1b).

Further south the raised bogs of the temperate region are found (fig. 2.2, IV 2). With increased summer temperatures and evapotranspiration, the importance of groundwater to guarantee the necessary water surplus increases and fen peatlands become more dominant.

Of course, transitional zones between regions exist as well as variability due to local topographic and climatic conditions, but overall the distribution of peatland types is rather clear cut.

\section{Land use}

Climate not only controls peatland occurrence and type, but also the potential for different types of land use strongly depends on climate. The permafrost peatlands of the arctic and subarctic zone are hardly used. Human impact is restricted to hunting and gathering, reindeer grazing and infrastructure (roads, pipelines). Whereas historically many boreal mires were mown and grazed, the peatlands of the boreal zone are currently mainly used for forestry or for peat extraction. Many boreal peatlands are naturally forested. Tree growth is, however, limited by waterlogging. Drainage removes this barrier and stimulates tree growth to allow for economically viable forestry. Large peatland areas in the boreal zone, especially in the hemiboreal and more continental parts, have also been drained for agriculture. 


\subsection{The role of peatlands in climate regulation and climate change mitigation}

Peatlands play an important role in global climate regulation. They constitute the largest terrestrial store of carbon. Under natural conditions they act as a net carbon sink, removing carbon dioxide $\left(\mathrm{CO}_{2}\right)$ from the atmosphere while at the same time emitting methane $\left(\mathrm{CH}_{4}\right)$. When drained they release large amounts of $\mathrm{CO}_{2}$ and nitrous oxide $\left(\mathrm{N}_{2} \mathrm{O}\right)$.

\section{Peatlands are the largest terrestrial store of carbon}

Peatland ecosystems (including peat and vegetation) contain disproportionally more organic carbon than other terrestrial ecosystems. In the (sub)arctic zone, peatlands contain on average 3.5 times more carbon per ha than ecosystems on mineral soil; in the boreal zone 7 times more; and in the humid tropics as much as 10 times more (Joosten \& Couwenberg 2008). While covering only $3 \%$ of the world's land area, peatlands contain 550 Gigatons (Gt) of carbon in their peat. Peatlands are the largest long-term carbon store in the terrestrial biosphere (Joosten \& Couwenberg 2008, box 1).

\section{Box 1. The Earth's carbon pools}

The largest pool of carbon is the ocean with 38,000 Gt C. Nearly all ocean carbon exists as dissolved inorganic carbon (DIC), largely as bicarbonate and carbonate ions, whereas some $1000 \mathrm{Gt} C$ are organic (Houghton 2007). The geologic pool contains 5,000-10,000 Gt C of organic carbon (as coal, gas and oil) (Lal 2003, Houghton 2007). The bedrock carbonates may comprise a similar amount of carbon as the ocean, but are normally disregarded as being largely immobile. Bedrock carbonates are, however, mobilized through metamorphosis in subduction zones or orogenic belts, through weathering at the Earth's surface and anthropogenically through mining for lime and cement production.

The soil is the third largest pool of carbon with an estimated 1,550 Gt C of soil organic carbon (SOC, Eswaran et al. 1993; Batjes 1996) and $950 \mathrm{Gt}$ C of soil inorganic carbon (SIC, Batjes 1996; Lal 2004) in the top meter and $842 \mathrm{Ct} C$ of SOC in the next $2 \mathrm{~m}$ of depth (Jobbágy \& Jackson 2000). As data on deeper layers are sparse, these estimates are tentative (Lal 1999). Information is especially incomplete for peat soils, which contain a substantial part of their $\mathrm{C}$ pool deeper than 1 meter (Jungkunst et al. 2012). Tarnocai et al. (2009) report that soils of the northern permafrost region contain $496 \mathrm{Gt} \mathrm{C}$ in the top meter (i.e. double the amount hitherto reported) and 1024 Gt until $3 \mathrm{~m}$ depth. 
The atmosphere contained (in 1990) $750 \mathrm{Gt} \mathrm{C}$, mainly as $\mathrm{CO}_{2}$ and $\mathrm{CH}_{4}$. The global terrestrial plant biomass is estimated to contain $650 \mathrm{Gt} \mathrm{C}$, the tree biomass of the world's forests $300 \mathrm{Gt} \mathrm{C}$ and the total forest biomass of the world $350 \mathrm{Gt} \mathrm{C}$ (Joosten \& Couwenberg 2008).

The huge carbon stock of peatland ecosystems lies in their often thick layers of peat. Peat is a highly concentrated stockpile of carbon that by definition consists of more than $30 \%$ (dry mass) of dead organic material (Joosten \& Clarke 2002) which contains 48-63\% of carbon (Heathwaite \& Göttlich 1993). The peat of the world holds 1375 t C on an average hectare (550 Gt / $400 \times 10^{6}$ ha), making it the most carbon dense stock of any terrestrial ecosystem. The second densest stock is the Giant Conifer forest in the Pacific West of North America which, before human disturbance, reached only half the carbon density of the average peatland (Joosten \& Couwenberg 2008).

The carbon content of global peat is equivalent to almost $25 \%$ of all global soil carbon, $75 \%$ of all atmospheric carbon, almost equal to all terrestrial biomass and twice the carbon stock in the forest biomass of the world (Joosten \& Couwenberg 2008, Box 1).

Under natural conditions peatlands are a long-term net carbon sink The peatlands existing today largely originated since the onset of the Holocene and have continued to accumulate since then (MacDonald et al. 2006). These peatlands have, in the past 10,000 years, withdrawn enormous amounts of carbon dioxide from the atmosphere and stored it in their peat deposits. Some scientists consider carbon sequestration in peatlands during interglacials as a major cause of decreasing atmospheric $\mathrm{CO}_{2}$ concentrations and as an important trigger for the renewed onset of glaciations (Franzén et al. 1996, Yu et al. 2003).

In all terrestrial ecosystems plants convert atmospheric $\mathrm{CO}_{2}$ into plant biomass that after death rapidly decays. In peatlands the dead plant material is subject to aerobic decay only for a limited time, because it soon arrives in a permanently water-logged, oxygen-poor environment, where the rate of decay is orders of magnitude lower (Clymo 1984). Dead plant material is continuously added to the toplayer of the peat where decomposition is aerobic and fast. Soon this material is overgrown and added to the permanently waterlogged and anaerobic layer. This layer (called the catotelm) is where peat accumu- 
lation takes place. About $5-15 \%$ of the net biomass produced is sequestered in the catotelm (Francez \& Vasander 1995).

Peat accumulation rates are dependent on climatic, hydrologic and hydrochemical conditions and show strong local and regional variation. In general, peat accumulation rates increase from nutrient rich to nutrient poor, from polar to equatorial and from continental to oceanic conditions (Turunen et al. 2002, Prager et al. 2006). Peat accumulation depends on the delicate balance between production and decay and other losses of organic material and natural peatlands may shift from carbon sinks to sources on seasonal and inter-annual time scales.

The long-term carbon balance of peatlands is positive but many peatlands may be close to the tipping point between carbon source or sink (cf. Holden et al. 2006). Peatland carbon sequestration rates may be sensitive to climatic fluctuations (Yu et al. 2003) and may show considerable yearto-year variability (Roulet et al. 2007) including short-term negative rates (Alm et al. 1999). Worldwide, the remaining area of pristine peatland ( $>3$

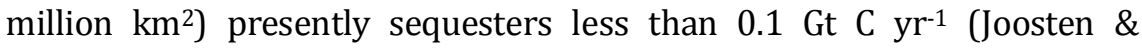
Couwenberg 2008).

\section{Fluxes of GHGs from peatlands are complex}

Natural peatlands play a complex role with respect to climate by affecting atmospheric burdens of $\mathrm{CO}_{2}$ and $\mathrm{CH}_{4}$. Under the wet conditions necessary for the formation of peat, part of the dead plant material is anaerobically decomposed, resulting in the emission of methane $\left(\mathrm{CH}_{4}\right)$ to the atmosphere. Natural peatlands are a major global source of $\mathrm{CH}_{4}$ (Kirschke et al. 2013). Although it only has a short atmospheric residence time (12 years), $\mathrm{CH}_{4}$ is a much stronger greenhouse gas than $\mathrm{CO}_{2}$. The Global warming potential (GWP) of $\mathrm{CH}_{4}$ over a 100 year time period is 23 times (or even 28 times, IPCC AR5) larger than that of $\mathrm{CO}_{2}$.

\section{Box 2: Global Warming Potential}

Global warming potential (GWP) is a relative measure of how much heat a greenhouse gas traps in the atmosphere. It compares the amount of heat trapped by a certain mass of the gas in question to the amount of heat trapped by a similar mass of carbon dioxide. GWP is calculated over a specific time interval, commonly 20, 100 or 500 years. GWP is expressed as a $\mathrm{CO}_{2}$-equivalent $\left(\mathrm{CO}_{2}\right.$-e), i.e. as a factor of carbon dioxide (whose GWP is standardized to 1). 
The combined climate effect of the $\mathrm{CO}_{2}$ and $\mathrm{CH}_{4}$ fluxes depends on the type and age of the peatland and is slightly positive or slightly negative on the 100 year timescale. On this time scale living peatlands thus have actually no effect on the climate because the sink effect of sequestered $\mathrm{CO}_{2}$ is annihilated by the source effect of emitted $\mathrm{CH}_{4}$. As, however, the $\mathrm{CH}_{4}$ concentration in the atmosphere from peatland emissions soon reaches a steady state as a consequence of rapid oxidation, whereas mires continue to absorb atmospheric $\mathrm{CO}_{2}$, the peatlands of the world cool the climate already since 11,000 years (Frolking et al. 2006, Frolking \& Roulet 2007).

Peatland related GHG fluxes are influenced by a wide range of interrelated biological, physical and chemical processes. Site-to-site variations in mean GHG fluxes are often closely related to the mean water table and soil temperature fluctuations (Sirin \& Laine 2008).

Water table is the single most important factor in peatland ecology and biochemistry and also determines GHG fluxes. The quantity and quality of water coming to the peatland via precipitation, groundwater discharge, upland inflow, flooding or other sources is the most important condition influencing peatland ecology and development. Water chemistry has a large influence on the plants that occur in a peatland and therefore on the character of peat that accumulates. Chemistry for a large part depends on the water table and its fluctuations. Furthermore, there is a strong link between temperature and water regime.

Water delivers various dissolved substances and suspended particles that may support GHG production and movement and water may remove these substances from the peatland leading to GHG emissions in adjacent systems like streams, ponds and drainage ditches (Sirin \& Laine 2008). Factors affecting peatland ecology and hydrology therefore greatly influence GHG fluxes from peatlands.

\section{Impacts of human intervention}

Conventional agriculture and forestry on peat soils involves drainage. Drainage leads to aeration which stops anaerobic decomposition and the associated emission of $\mathrm{CH}_{4}$. However, aeration also leads to aerobic decomposition of the peat, resulting in the emission of $\mathrm{CO}_{2}$ and $\mathrm{N}_{2} \mathrm{O}$ (GWP 265, IPCC 2013) to the atmosphere. These emissions continue as long as the peatland remains drained or all the peat is oxidized. In addition to the release of $\mathrm{CO}_{2}$ and $\mathrm{N}_{2} \mathrm{O}$, large amounts of $\mathrm{CH}_{4}$ are emitted from drainage ditches that also carry increased amounts of dissolved organic carbon (DOC) out of the peatland. This DOC is then largely decomposed off-site and emitted to the atmosphere as $\mathrm{CO}_{2}$. GHG emissions from 
drained peatlands generally increase with deeper drainage and warmer climates (IPCC 2014).

Currently 65 million ha of the global peatland area are degraded, largely as a result of drainage. Peat oxidation from this area (i.e. from $0.6 \%$ of the Earth's land surface) is responsible for $\mathrm{CO}_{2}$ emissions of $1,150 \mathrm{Gt} \mathrm{CO}_{2} \mathrm{yr}^{-1}$ (Joosten 2009, unpublished update 2014; excluding fires), which is equivalent to $3 \%$ of the total global anthropogenic $\mathrm{CO}_{2-}$ emissions ( $\sim 39 \mathrm{Gt} \mathrm{CO}_{2} \mathrm{e}$; Le Quéré et al. 2013). When peat fires (mainly in Southeast Asia) are included in the estimates, the global land use related emissions from peatlands are likely to be twice as high.

\section{Peatlands drained for agriculture}

Drained peatlands under agriculture are used as croplands and grasslands. In Europe, drained agriculturally used peat soils are responsible for a large part of the greenhouse gas emissions from agriculture. Carbon stocks and hence losses from mineral soils are small compared to those from peat soils and the vast majority of soil carbon loss is from peat soils. We calculated carbon loss from agricultural soils on the basis of the National Inventory Reports that countries submit each year to the UNFCCC (fig. 2.3). For countries using default 2006 IPCC emissions factors (Estonia, Iceland, Latvia, Lithuania, Poland, Russia) these emission factors were substituted with the updated factors provided in the IPCC 2013 Wetland Supplement (IPCC 2014; table 2.1). Emission percentages can be above $100 \%$ because some countries claim (large) sinks in mineral soil croplands and particularly grasslands (but see Smith 2014). Total net carbon emissions and removals from agricultural soils can thus be lower than the losses from organic soils alone. Also $\mathrm{N}_{2} \mathrm{O}$ emissions from agriculturally used peat soils are disproportionally large compared to the area they occupy (fig. 2.4). 


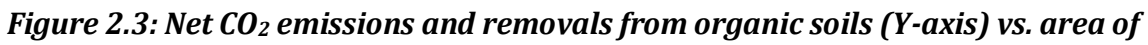
organic soils under agriculture (X-axis) in selected European countries

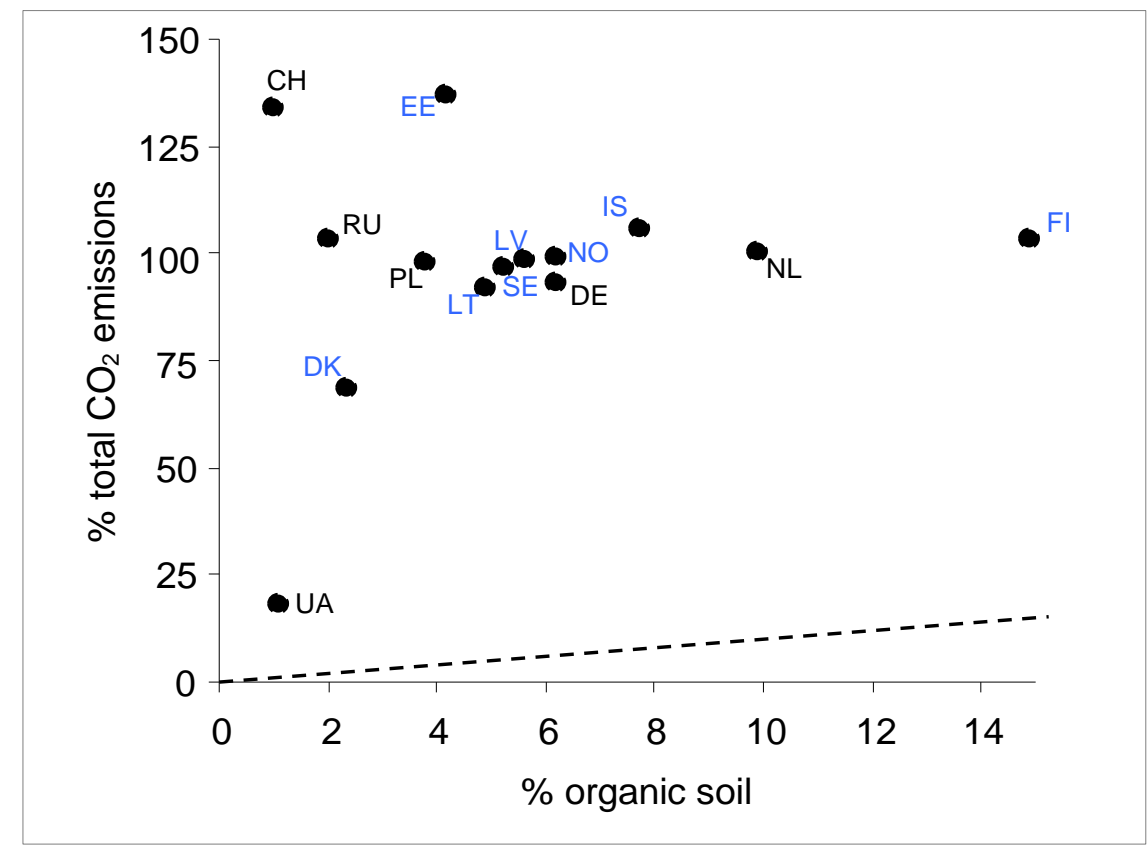

Emissions are expressed as percentage of total emissions from agricultural soils; the area of organic soils as percentage of total area under agriculture (cropland and grassland). The dashed line depicts the 1:1 ratio. Countries included in the project are marked blue. $\mathrm{CH}$ : Switzerland, DE: Germany, DK: Denmark, EE: Estonia, FI: Finland, IS: Iceland, LT: Lithuania, LV: Latvia, NL: Netherlands, NO: Norway, PL: Poland, RU: Russia, SE: Sweden, UA: Ukraine

Figure 2.4: $\mathrm{N}_{2} \mathrm{O}$ emissions from organic soils (Y-axis) vs. area of organic soils under agriculture (X-axis) in selected European countries

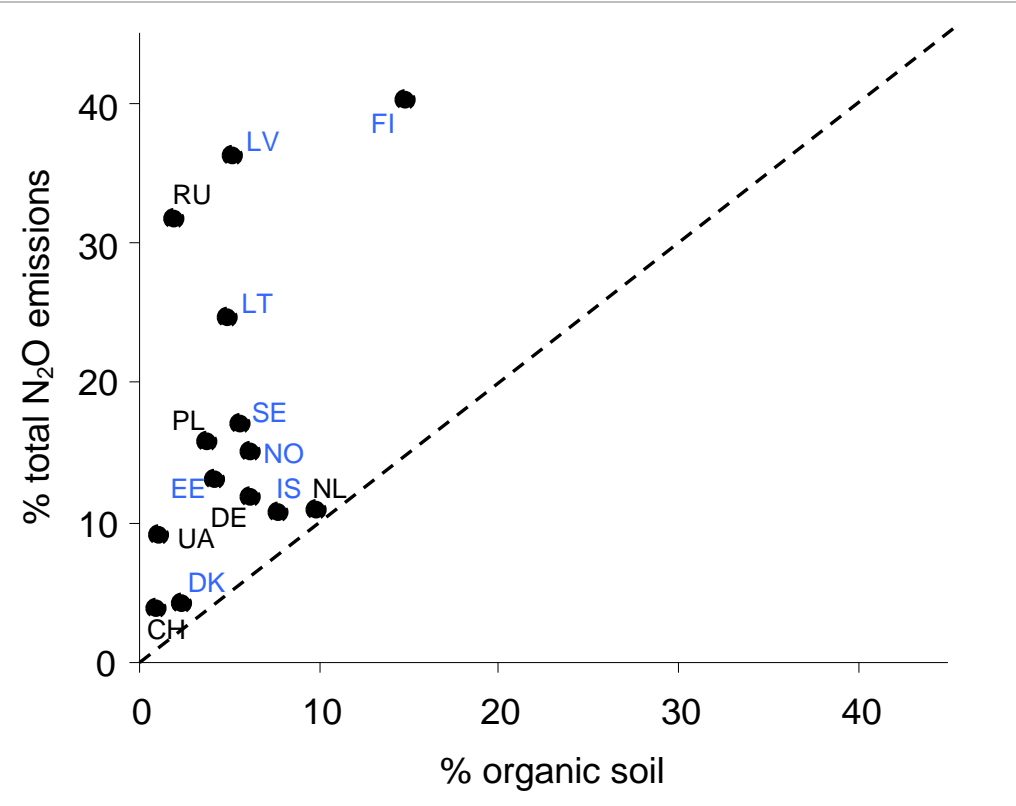


Expressing $\mathrm{N}_{2} \mathrm{O}$ emissions in terms of global warming potential allows calculation of total $\mathrm{CO}_{2}$ equivalent $\left(\mathrm{CO}_{2} \mathrm{e}\right)$ emissions from agriculturally used land. In all European countries in which peat soils constitute more than $3 \%$ of the agricultural land area, agriculturally drained peatlands are responsible for the majority ( $>50 \%$ ) of greenhouse gas emissions associated with agricultural land use (fig. 2.5 and 2.6).

Figure 2.5: Net greenhouse gas emissions from organic soils (Y-axis) vs. area of organic soils under agriculture (X-axis) in selected European countries. The dashed line depicts the 1:1 ratio, the dotted line a crude logarithmic fit. (GWP of $\mathrm{N}_{2} \mathrm{O}=298$ )

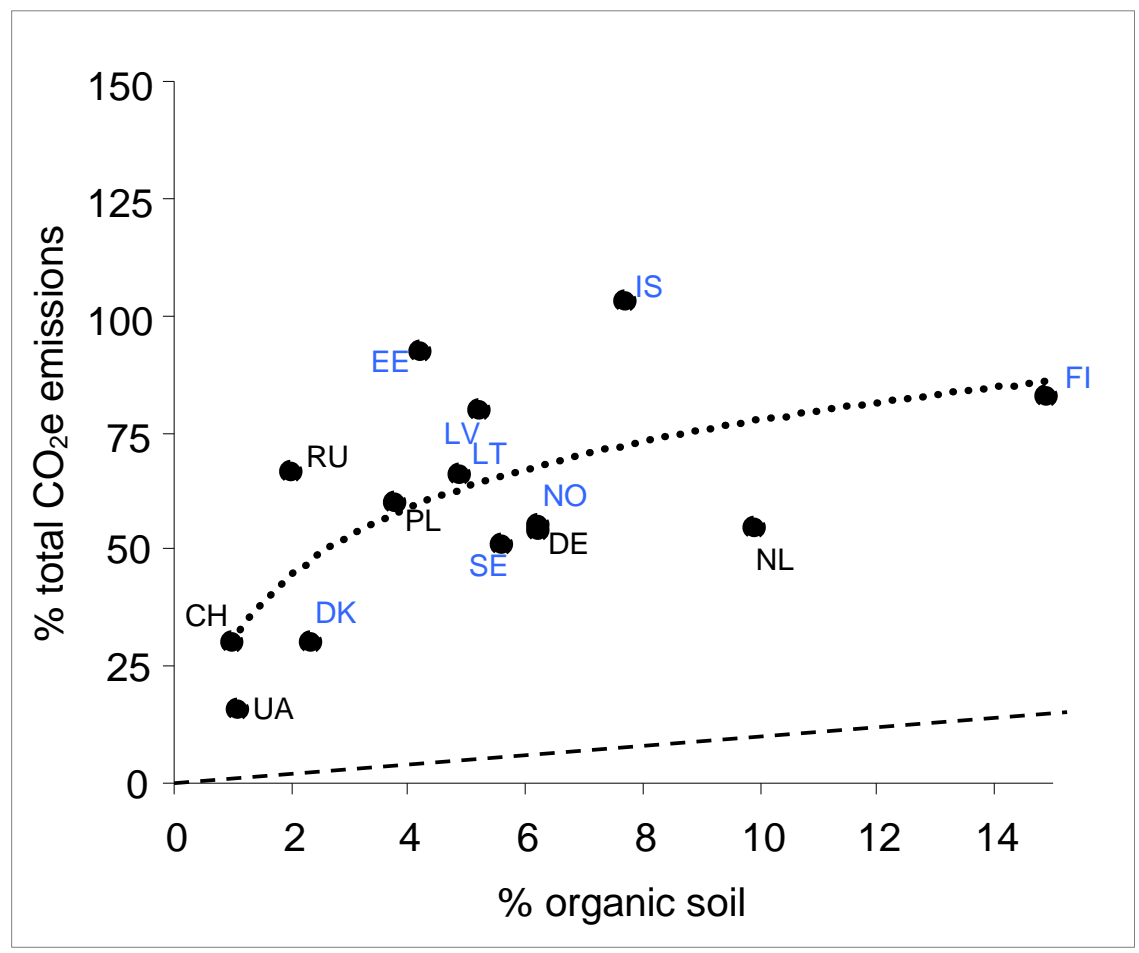


Fig. 2.6: $\mathrm{CO}_{2}$ emissions ( $\mathrm{Y}$-axis) vs. $\mathrm{N}_{2} \mathrm{O}$ emissions ( $\mathrm{X}$-axis) from organic soils in selected European countries. The dashed line depicts the 1:1 ratio. For data points above and to the right of the red line emissions from organic soils constitute the majority of emissions from agricultural soils

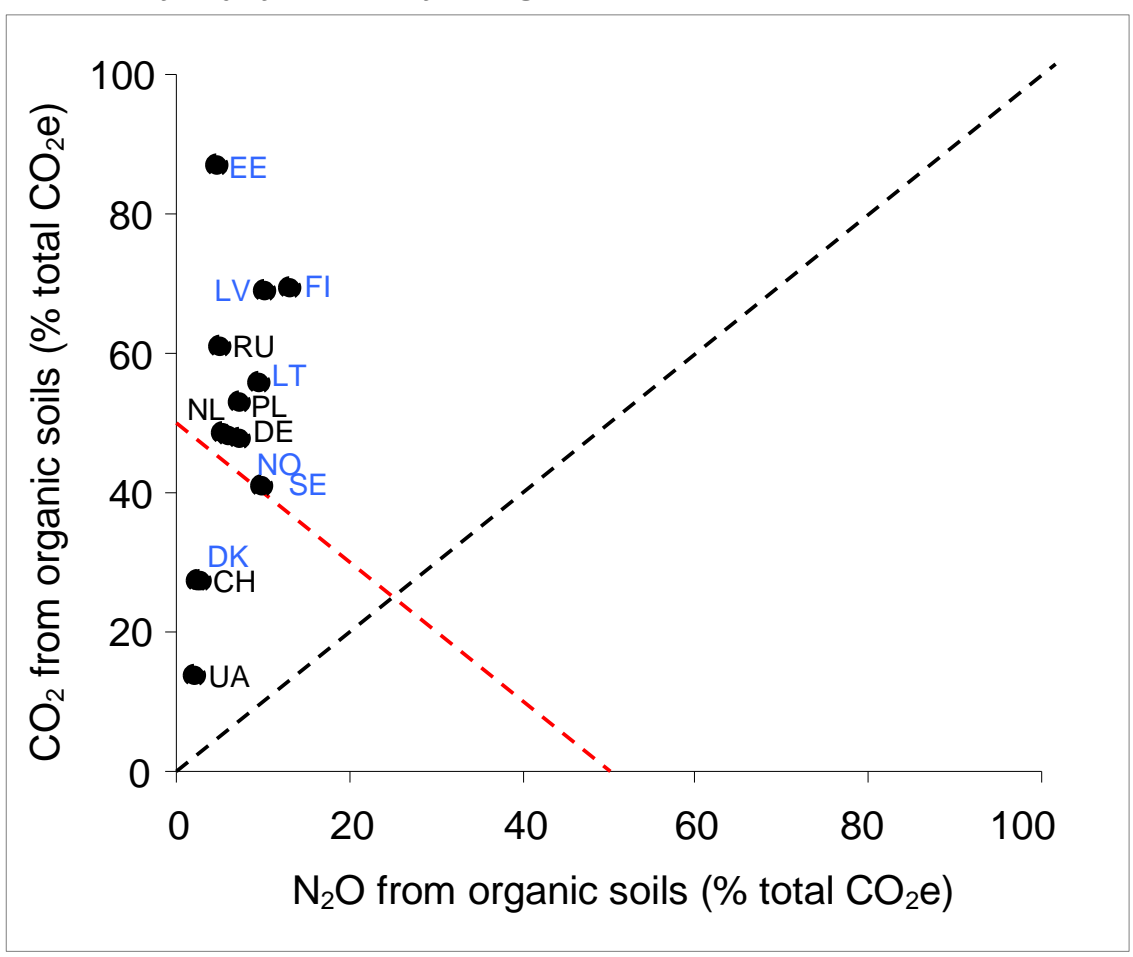

The IPCC 2013 Supplement: Wetlands (IPCC 2014) provides new emission factors for agriculturally drained peatlands (table 2.1). For drainage ditches in peatlands under agriculture, the default emission factor is $1.165 \mathrm{~kg} \mathrm{CH}_{4} \mathrm{ha}^{-1} \mathrm{yr}^{-1}$ for deeply and $527 \mathrm{~kg} \mathrm{CH}_{4} \mathrm{ha}^{-1} \mathrm{yr}^{-1}$ for shallowly drained areas; this value must be combined with ditch density, for which a default is given of $5 \%$ of the area. 
Table 2.1: Emission factors for agriculturally drained peat soils (after IPCC 2014). Values for $\mathrm{CH}_{4}$ include emission from drainage ditches. For calculation a Global Warming Potential (GWP) of 23 is used for $\mathrm{CH}_{4}$ and 298 for $\mathrm{N}_{2} \mathrm{O}$

\begin{tabular}{|c|c|c|c|c|c|}
\hline & $\begin{array}{r}\mathrm{t} \mathrm{CO}_{2} \\
\mathrm{ha}^{-1} \mathrm{yr}^{-1}\end{array}$ & $\begin{array}{l}\mathrm{DOC} \mathrm{tCO}_{2} \\
\mathrm{ha}^{-1} \mathrm{yr}^{-1}\end{array}$ & $\begin{array}{l}\mathrm{kg} \mathrm{CH}_{4} \\
\mathrm{ha}^{-1} \mathrm{yr}^{-1}\end{array}$ & $\begin{array}{l}\mathrm{kg} \mathrm{N}_{2} \mathrm{O} \\
\mathrm{ha}^{-1} \mathrm{yr}^{-1}\end{array}$ & $\begin{array}{r}\text { Total GWP } \\
\mathrm{t} \mathrm{CO}_{2} \mathrm{e} \mathrm{ha}^{-1} \mathrm{yr}^{-1}\end{array}$ \\
\hline Cropland, boreal & 29.0 & 0.44 & 58.3 & 20.4 & 36.8 \\
\hline Cropland, temperate & 29.0 & 1.14 & 58.3 & 20.4 & 37.5 \\
\hline Grassland, boreal & 20.9 & 0.44 & 59.6 & 14.9 & 27.2 \\
\hline Grassland, temperate, nutrient poor & 19.4 & 1.14 & 60.0 & 6.8 & 24.0 \\
\hline $\begin{array}{l}\text { Grassland, temperate, nutrient rich, } \\
\text { deep drained }\end{array}$ & 22.4 & 1.14 & 73.5 & 12.9 & 29.0 \\
\hline $\begin{array}{l}\text { Grassland, temperate, nutrient rich, } \\
\text { shallow drained }\end{array}$ & 13.2 & 1.14 & 63.5 & 2.5 & 16.5 \\
\hline
\end{tabular}

In undrained peatlands livestock production and overgrazing can lead to erosion and consequent carbon losses (Evans et al. 2005), especially in upland peat areas (Backshall et al. 2001). Overgrazing leaves bare organic surfaces that are susceptible to erosion by water and wind. Fertilisation with manure stimulates peat oxidation and erosion. In turn this increases the release of $\mathrm{CO}_{2}$ and on- and offsite $\mathrm{CH}_{4}$ and $\mathrm{N}_{2} \mathrm{O}$ emissions.

\section{Peatlands drained for forestry}

When peatland is drained for forestry, various processes occur simultaneously with contrasting effects. The integrated effects differ considerably in different areas and over different time-scales (Crill et al. 2000, Joosten 2000). After drainage increased aeration of the peat results in faster peat mineralization and a decrease in the peat carbon store. In the boreal zone this aeration may be accompanied by a lowering of the peat $\mathrm{pH}$ and temperature, which may again reduce the rate of peat mineralization. After drainage, forest vegetation (trees and shrubs etc.) takes the place of the original, lower and more open mire vegetation. The increased interception and transpiration add substantially to the lowering of the water table, often even more than drainage. The peatland biomass carbon store (both above and below ground) increases quickly and this store eventually reaches a new equilibrium that is much higher than that of the pristine peatland. Before this stage is reached, however, the wood is normally harvested and the biomass store is once again substantially reduced.

Peatland drainage for forestry also leads to changes in the litter carbon store. The "moist litter" in the upper layer of a pristine peatland is generally considered part of the peat, as it gradually passes into the catotelm. The quality of the litter in a drained forest (consisting of remains of leaves and needles, branches, rootlets, mosses, etc.) differs from the 
soil below. The accumulation of litter eventually reaches equilibrium, which, depending on the peatland type and the cutting regime of the forest may take centuries. Peatland drainage for forestry therefore leads to a steady decrease in the peat carbon store, a rapid initial increase in the biomass store, the harvesting of which leads to a typical "saw-tooth" curve of the carbon biomass store, and a slow increase in the peatland litter store, which eventually reaches an equilibrium. In boreal areas the growing tree stand leads to a reduced albedo, which affects the radiative balance significantly and constitutes an additional climate warming effect that balances out or even exceeds the cooling effect due to changing GHG fluxes (Lohila et al. 2010).

Also in forested peatlands $\mathrm{CH}_{4}$ emissions from drainage can have substantial impact on the overall GHG emissions from forestry drained peatlands (Minkkinen \& Laine 2006). On nutrient-rich sites drainage for forestry may result in considerable $\mathrm{N}_{2} \mathrm{O}$ release to the atmosphere (Martikainen et al. 1995, von Arnold et al. 2005, Ojanen et al. 2010). The IPCC 2013 Supplement: Wetlands (IPCC 2014) provides new emission factors for forestry drained peatlands (table 2.2). For drainage ditches in peatlands under forestry, the default emission factor is $217 \mathrm{~kg} \mathrm{CH}_{4} \mathrm{ha}^{-1} \mathrm{yr}^{-1}$; this value must be combined with ditch density, for which a default is given of $2.5 \%$ of the area.

\begin{tabular}{|c|c|c|c|c|c|}
\hline & $\begin{array}{r}\mathrm{tCO}_{2} \\
\mathrm{ha}^{-1} \mathrm{yr}^{-1}\end{array}$ & $\mathrm{t} \mathrm{CO}_{2} \begin{array}{r}\text { DOC } \\
\mathrm{ha}^{-1} \mathrm{yr}^{-1}\end{array}$ & $\begin{array}{l}\mathrm{kg} \mathrm{CH}_{4} \\
\mathrm{ha}^{-1} \mathrm{yr}^{-1}\end{array}$ & $\begin{array}{r}\mathrm{kg} \mathrm{N}_{2} \mathrm{O} \\
\mathrm{ha}^{-1} \mathrm{yr}^{-1}\end{array}$ & $\begin{array}{r}\text { Total GWP } \\
\text { (t } \mathrm{CO}_{2} \mathrm{e} \mathrm{ha}^{-1} \mathrm{yr}^{-1}\end{array}$ \\
\hline Boreal, nutrient poor & 0.92 & 0.44 & 7.0 & 0.35 & 1.7 \\
\hline Boreal, nutrient rich & 3.41 & 0.44 & 2.1 & 5.0 & 5.5 \\
\hline Temperate & 9.53 & 1.14 & 2.6 & 4.4 & 12.2 \\
\hline
\end{tabular}

Peat extraction.

Extraction of peat for fuel, horticulture, landscaping and other purposes rapidly removes carbon from the peatland, leading to a loss of 20-35 t C ha $^{-1} \mathrm{yr}^{-1}$ in modern peat fields (Cleary et al. 2005). Peat extraction also leads to substantial carbon losses through vegetation removal during site preparation, drainage of the extraction site and its surroundings, the peat collection process (e.g. milling which increases aeration and oxidation of the upper peat layer) and storage (in stockpiles) (Sundh et al. 2000, Crill et al. 2000, Waddington et al. 2002, Cleary et al. 2005). In addition, the bare dark and lightweight soils are easily warmed and susceptible to wind and water erosion (Holden et al. 2006). In case of fuel peat extraction, the peat is immediately oxidised; in case of horticultural 
peat within some years. A life-cycle analysis of nonfuel peat extraction in Canada showed that the decomposition of the extracted peat is responsible for $71 \%$ of the total atmospheric carbon release (Cleary et al. 2005). Land use change (removal of vegetation etc.), the transport of peat to the market, and extraction and processing activities comprise $15 \%, 10 \%$, and $4 \%$, respectively.

Abandoned peat extraction sites that are not rewetted remain important sources of carbon emissions (Mäkiranta et al. 2007). Often the peat surface remains without vegetation for many years after extraction has stopped. The dry conditions resulting from intensive drainage not only cause peat decomposition, but may lead to fires and large associated carbon emissions. The main greenhouse gas flux from (former) peat extraction fields is $\mathrm{CO}_{2}$, although high $\mathrm{CH}_{4}$ effluxes may occur from drainage ditches. Notable $\mathrm{CH}_{4}$ flux rates have furthermore been observed from milled peat surface after the snowmelt in spring, as well as from stockpiles (Chistotin et al. 2006).

The IPCC 2013 Supplement: Wetlands (IPCC 2014) provides new emission factors for peatlands drained for peat extraction (table 2.3). For drainage ditches, the default emission factor is $542 \mathrm{~kg} \mathrm{CH}_{4} \mathrm{ha}^{-1} \mathrm{yr}^{-1}$; this value must be combined with ditch density, for which a default is given of $5 \%$ of the area. Emissions from stockpiles are not assessed by IPCC (2014).

\begin{tabular}{|c|c|c|c|c|c|}
\hline & $\mathrm{tCO} \mathrm{Ca}^{-1} \mathrm{yr}^{-1}$ & $\begin{array}{r}\mathrm{DOC}+\mathrm{CO}_{2} \\
\mathrm{ha}^{-1} \mathrm{yr}^{-1}\end{array}$ & $\mathrm{~kg} \mathrm{CH}_{4} \mathrm{ha}^{-1} \mathrm{yr}^{-1}$ & $\mathrm{~kg} \mathrm{~N}_{2} \mathrm{O} \mathrm{ha}^{-1} \mathrm{yr}^{-1}$ & $\begin{array}{r}\text { Total GWP } \\
\mathrm{t} \mathrm{CO}_{2} \mathrm{e} \mathrm{ha}^{-1} \mathrm{yr}^{-1}\end{array}$ \\
\hline $\begin{array}{l}\text { Peat extraction, } \\
\text { boreal }\end{array}$ & 10.3 & 0.44 & 7.2 & 0.5 & 11.6 \\
\hline $\begin{array}{l}\text { Peat extraction, } \\
\text { temperate }\end{array}$ & 10.3 & 1.14 & 7.2 & 0.5 & 12.3 \\
\hline
\end{tabular}

\section{Rewetted peatlands}

Peatland drainage is not only associated with increased GHG emissions and fire risk, but also with soil subsidence and ultimately loss of productive land, with increased nutrient loads to surface waters as well as with the loss of biodiversity. To solve these problems restoration activities have increased in recent years. The major practice involved in peatland restoration is reversing drainage, or raising the water table (rewetting). A meta-analysis carried out in the framework of the 2013 IPCC Supplement: Wetlands (IPCC 2014) showed that if the water table is restored to 
pre-drainage levels, GHG fluxes are comparable to fluxes from undrained peatlands. In other words: $\mathrm{CO}_{2}$ emissions decrease or even become negative (peat accumulation), $\mathrm{N}_{2} \mathrm{O}$ emissions are $\sim 0$ and $\mathrm{CH}_{4}$ emissions increase compared to the drained state. It takes a while for the rewetted peatland to adapt to the new situation. During the first years after rewetting GHG fluxes tend to deviate from pristine sites. Rewetted nutrient poor sites usually show lower and rewetted nutrient rich sites higher $\mathrm{CH}_{4}$ emissions than pristine sites.

Methane emissions from pristine peatlands are by definition not part of anthropogenic climate change. Countries need not (and do not) account for natural GHG emissions and removals. When drained peatlands are rewetted, the arising $\mathrm{CH}_{4}$ emissions are anthropogenic, however, as they are caused by human intervention. Consequently, they must be accounted for. Under UNFCCC land cannot be "given back" to nature, but is considered managed land even if management is restricted to a onetime event of carrying out rewetting measures. Discussions on what constitutes managed land are ongoing and a consistent approach across different types of land use and ecosystems is hard to reach. Meanwhile, the $\mathrm{CH}_{4}$ emissions from rewetted peatlands should be accounted for even if they are now occurring in nature reserves.

Because $\mathrm{CH}_{4}$ has a 23 times stronger climate effect than $\mathrm{CO}_{2}$ (the new IPCC AR5 even assumes 28 times), rewetting does not necessarily result in climate gain. The IPCC 2013 Supplement: Wetlands (IPCC 2014) provides new emission factors for rewetted peatlands (table 2.4).

\begin{tabular}{|c|c|c|c|c|c|}
\hline & t $\mathrm{CO}_{2} \mathrm{ha}^{-1} \mathrm{yr}^{-1}$ & $\mathrm{t} \mathrm{CO}_{2} \mathrm{ha}^{\mathrm{DOC}} \mathrm{yr}^{-1}$ & $\begin{array}{l}\mathrm{kg} \mathrm{CH}_{4} \\
\mathrm{ha}^{-1} \mathrm{yr}^{-1}\end{array}$ & $\begin{array}{r}\mathrm{kg} \mathrm{N}_{2} \mathrm{O} \\
\mathrm{ha}^{-1} \mathrm{yr}^{-1}\end{array}$ & $\begin{array}{r}\text { Total GWP } \\
\text { t } \mathrm{CO}_{2} \mathrm{e} \mathrm{ha}^{-1} \mathrm{yr}^{-1}\end{array}$ \\
\hline $\begin{array}{l}\text { Rewetted, boreal, } \\
\text { nutrient poor }\end{array}$ & -1.3 & 0.3 & 54.7 & 0 & 0.3 \\
\hline $\begin{array}{l}\text { Rewetted, boreal, } \\
\text { nutrient rich }\end{array}$ & -2.0 & 0.3 & 182.7 & 0 & 2.5 \\
\hline $\begin{array}{l}\text { Rewetted, temperate, } \\
\text { nutrient poor }\end{array}$ & -0.8 & 0.9 & 122.7 & 0 & 2.9 \\
\hline $\begin{array}{l}\text { Rewetted, temperate, } \\
\text { nutrient rich }\end{array}$ & 1.8 & 0.9 & 288.0 & 0 & 9.3 \\
\hline
\end{tabular}




\section{Consequences for climate change mitigation by peatlands}

The major conclusions of the overview presented above can be summarized (and simplified) as follows:

- Natural peatlands do not have an effect on the climate on the time scale relevant for climate change policies, because $\mathrm{CH}_{4}$ emissions outbalance $\mathrm{CO}_{2}$ sequestration.

- Even if the climate effect of natural peatlands would be positive, this effect cannot be accounted for as climate change mitigation, as the effect does not result from human activities.

- Rewetted peatlands do not become "positive" for the climate in an absolute sense (and on the 100 year timescale). Because of the reintroduced $\mathrm{CH}_{4}$ emissions (that have to be accounted as anthropogenic emissions!), rewetted peatlands remain in an absolute sense largely negative for the climate. The benefit of peatland rewetting is in the fact that the net GHG emissions from rewetted peatlands are much lower compared to those from drained peatlands.

- A substantial and accountable reduction of GHG emissions can be achieved by rewetting of drained peatlands.

Further considerations and consequences for Ramsar policies and designation criteria are discussed in Chapter 3 (especially the relation to UNFCCC policies) and Chapter 4 (Ramsar site designation criteria).

\subsection{The climate effect of Nordic-Baltic peatlands}

In the NorBalWet countries large areas of peatland have been drained. For the total study area the percentage of drained peatlands amounts to $44.0 \%$ (table 2.5), which is a high value compared to the percentage of peatlands drained in the entire World (c. 12\%), but rather low compared to the total of Europe (almost 60\%, Joosten 2009). The rather positive picture compared to Europe is, however, attributable to only two countries, Norway and Sweden, in which less than $20 \%$ of the peatlands have been drained. All other countries (excl. Greenland where the total peatland area is too small to influence the NorBalWet statistics) have $2 / 3$ or more of their peatland area drained (table 2.5). 
With $78 \mathrm{Mt}$ annually (table 2.5) the studied NorBalWet countries contribute some $6 \%$ to the worldwide anthropogenic peatland $\mathrm{CO}_{2}$ emissions of $1150 \mathrm{Mt} \mathrm{yr}^{-1}$ (without fires) and some $0.2 \%$ to the total

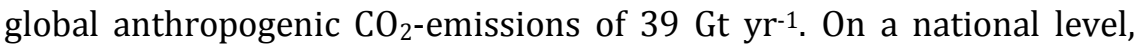
however, the importance of peatland emissions for the $\mathrm{CO}_{2}$ budget is considerably larger. In Iceland and Latvia the emissions from peatlands are double as large as the total $\mathrm{CO}_{2}$-emissions from all other sources (excl. LULUCF). In Estonia, Lithuania and Finland peatland $\mathrm{CO}_{2}$ emissions amount to (almost) half of the total other $\mathrm{CO}_{2}$-emissions (excl. LULUCF). Only in Denmark and Greenland peatland emissions are less than $10 \%$ of the total other $\mathrm{CO}_{2}$-emissions (excl. LULUCF). These figures show convincingly that peatlands could/should play an important role in national climate policies.

Further details on these figures and their bearing on national Ramsar strategies are discussed in chapter 3.

Table 2.5: Peatland areas, total country $\mathrm{CO}_{2}$ emissions in 2012 (without LULUCF), and $\mathrm{CO}_{2}$ emissions from peatlands in the NorBalWet countries. Peatland data derived from the country overviews (see Annex country profiles), total emissions derived from the 2014 National Inventory Reports of the respective countries

\begin{tabular}{|c|c|c|c|c|c|c|}
\hline & \multirow{2}{*}{$\begin{array}{l}\begin{array}{l}\text { a. Total } \\
\text { peatland area }\end{array} \\
\mathrm{km}^{2}\end{array}$} & \multicolumn{2}{|c|}{$\begin{array}{c}\text { b. Drained } \\
\text { peatland area }\end{array}$} & \multirow{2}{*}{$\begin{array}{r}\text { c. Total } \mathrm{CO}_{2} \text { emissions } \\
\text { without LULUCF } \\
\mathrm{Mt} \mathrm{CO}_{2} \mathrm{yr}^{-1}\end{array}$} & \multicolumn{2}{|c|}{$\begin{array}{l}\text { d. Total peatland } \\
\mathrm{CO}_{2} \text { emissions }\end{array}$} \\
\hline & & $\mathrm{km}^{2}$ & $\% b$ of $a$ & & $\mathrm{Mt} \mathrm{CO} \mathrm{yr}^{-1}$ & $\% d$ of $c$ \\
\hline Estonia & 9,150 & 6,619 & 72.3 & 17.08 & 8,04 & 47,1 \\
\hline Latvia & $11,143^{1)}$ & $7,978^{1)}$ & 71.6 & 7.43 & 13.53 & 182.0 \\
\hline Lithuania & 6,460 & 4,679 & 72.4 & 14.84 & 7.70 & 51.9 \\
\hline Finland & 83,198 & $64,931^{1)}$ & 78.0 & 50.70 & 20.68 & 40.8 \\
\hline Sweden & $85,023^{1)}$ & $15,458^{1)}$ & 18.2 & 45.71 & 10.58 & 23.1 \\
\hline Norway & $46,211^{1)}$ & $4,348^{1)}$ & 9.4 & 52.70 & 6.26 & 11.9 \\
\hline Iceland & $5,777^{1)}$ & $3,665^{1)}$ & 63.4 & 3.32 & 7.66 & 230.4 \\
\hline Denmark & $2,029^{1)}$ & $1,892^{1)}$ & 93.2 & 38.03 & 3.34 & 8.8 \\
\hline Greenland & $75^{1)}$ & $3^{1)}$ & 4.0 & 0.60 & 0.00 & 0.3 \\
\hline Total & 249,066 & 109,573 & 44.0 & 230.42 & 77.79 & 33.8 \\
\hline
\end{tabular}

1) Peatland data were not available or considered to be unreliable. Therefore organic soil data have been used. References are given in the respective country chapters. 


\section{Relation to other international conventions and policies}

\subsection{Introduction}

The benefits of coordination and collaboration amongst conventions and international organizations with related or overlapping missions are widely recognized. The Ramsar Secretariat has devoted much effort to developing synergies with other environment-related instruments and encourages Ramsar's Administrative Authorities to build close working relationships with their counterparts of other conventions at the national level. This chapter

- gives a short overview of the importance of other conventions and regulations for the peatland-climate issue

- describes the steps taken to stimulate synergies between the Ramsar Convention and other conventions, especially with respect to peatlands and climate change

- identifies topical developments and initiatives.

\subsection{The UN Framework Convention on Climate Change (UNFCCC)}

Peatland rewetting and conservation within the Climate Convention The United Nations Framework Convention on Climate Change (UNFCCC) has as its goal to achieve "stabilization of greenhouse gas concentrations in the atmosphere at a level that would prevent dangerous anthropogenic interference with the climate system" (UNFCCC art. 2). Progress with respect to this goal is monitored by means of greenhouse gas inventories that all countries regularly have to submit. 
The Kyoto Protocol (KP) is hitherto the only legally binding mechanism within the UNFCCC. Under the Protocol, industrialized countries and countries in transition to a market economy (together called the "annex I countries") have legally binding emission limitation and reduction commitments. For the first commitment period (2008-2012) these countries (incl. all NorBalWet countries) had obliged themselves to reduce their greenhouse gas (GHG) emissions collectively with $5.2 \%$ compared to 1990.

The Kyoto Protocol was developed to curb industrial GHG emissions (GHG sources). Simultaneously the possibility was opened for compensating these emissions by improved land management (GHG sinks) in the so-called LULUCF (Land Use, Land Use Change and Forestry) sector, where - especially in the forest sector - substantial sequestration of carbon was expected. The first land use activities that came in mind as carbon sinks were thus Afforestation and Reforestation and consequently accounting for these activities (and their reverse "Deforestation") was made mandatory under the Kyoto Protocol (KP art. 3.3). In contrast, accounting for all other types of land use (i.e. Forest Management, Cropland Management, Grazing land Management and Revegetation) was made voluntary (KP art. 3.4). This means that countries were allowed to choose whether to account for these activities or to neglect the associated GHG fluxes (which in case of peatlands implies the neglect of substantial emissions; cf. chapter 2).

If a country chooses to account a specific "activity", it has to account all net GHG fluxes on all lands subject to that activity. If Germany, for example, would want to claim emissions reductions from the $600 \mathrm{~km}^{2}$ of peat grasslands it has rewetted, it would also have to account for the emissions from the remaining $6,000 \mathrm{~km}^{2}$ of heavily emitting grassland on drained peatland and for the $60,000 \mathrm{~km}^{2}$ of grassland on mineral soil.

This requirement has had as a consequence that out of all 37 annex I countries worldwide only 4 countries (incl. Denmark) chose Cropland Management, only 2 countries (incl. again Denmark) chose Grazing land Management and only 3 countries (incl. Iceland) chose Revegetation for the first commitment period (table 3.1). Reasons for the reluctance to choose these activities were the assumed complexity in monitoring and the unclear or assumed negative consequences for the national GHG budget. In contrast, 23 countries (incl. most NorBalWet countries) chose Forest Management, because the monitoring of carbon stock changes in forests (as a proxy of GHG fluxes) was assumed to be better feasible (cf. the long forestry experience) and a positive outcome was expected from forest carbon sequestration for the national carbon budget. 


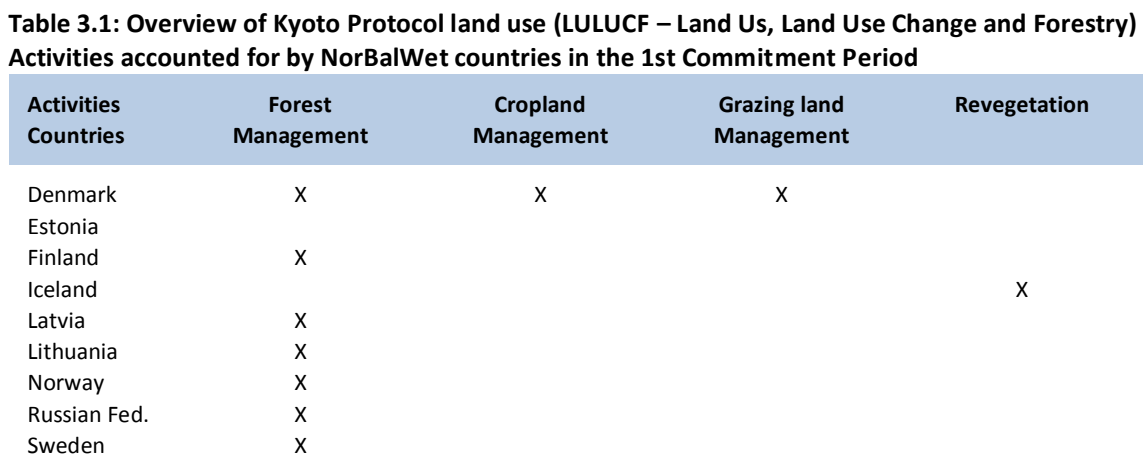

The Kyoto Protocol thus provided no incentives for peatland rewetting in the first commitment period. Rewetting of peatland used as cropland or grazing land, i.e. the hotspots of land bound emissions in most countries (figs. 2.3-2.6), could not be accounted for as long as the associated activities (Cropland Management and Grazing land Management) were not elected. Rewetting drained peatlands in conservation areas or former peat extraction sites was even completely discouraged as no activities (except "revegetation") were eligible for these types of lands, so emission reductions by rewetting these lands could not be accounted for.

It has specifically been NorBalWet country Iceland that since 2008 in cooperation with Belarus - has been striving to find a way out of this Kyoto Protocol impasse. Consequently, in Durban 2012 the UNFCCC adopted the new activity "Wetland drainage and rewetting" under the Kyoto Protocol with the specific aim to make the rewetting of peatlands more easily accountable.

For the second commitment period of the Kyoto Protocol (20132020), UNFCCC decided to expand the number of mandatory activities with Forest Management and all activities that countries had already chosen for the first commitment period. "Wetland drainage and rewetting" was added as a voluntary activity for which countries may choose to account or not. 


\section{Box 3: The Kyoto Protocol activity Wetland Drainage and Rewetting}

The official UNFCCC definition of this new Kyoto Protocol activity is:

"Wetland drainage and rewetting' is a system of practices for draining and rewetting on land with organic soil that covers a minimum area of 1 hectare. The activity applies to all lands that have been drained since 1990 and to all lands that have been rewetted since 1990 and that are not accounted for under any other activity as defined in this annex, where drainage is the direct humaninduced lowering of the soil water table and rewetting is the direct humaninduced partial or total reversal of drainage."

Some clarification of the phrasing:

- The combination "drainage and rewetting' establishes a balance: if climatically positive activities are accounted for, the same must apply to their negative counterparts. This to prevent that countries would rewet and account for areas they had just (unaccountedly) drained.

- The activity has explicitly been restricted to land with organic soil (peatlands). Other wetlands (cf. the Ramsar or IPCC definition of wetlands) are not covered. It is indeed confusing that the name "Wetland Drainage and Rewetting" inadequately reflects the content because the activity not applies to wetlands in general, but only to organic soils (peatlands). The name, however, was a political compromise to reach unanimity among countries without changing the content of the activity.

- The restriction "a minimum area of 1 ha' was made to prevent that every single ditch and every single ditch filling has to be monitored and reported.

- The date 1990 expresses that areas where the water level has been lowered (or raised) before 1990 and where this lower (higher) water level since has been maintained, are no subject of the activity. In the NorBalWet countries (and actually all other Annex 1 countries) hardly any new drainage of peatlands has taken place after 1990. The break-off date 1990 thus implies that the vast majority of drained peatlands has not to be accounted for, and that countries are not punished for what has happened long time ago. As the standard Kyoto Protocol reference year, in comparison to which emissions reductions have to be calculated, is also 1990, accounting for pre 1990 drained land that has been kept drained until present would anyhow be a zero sum game. Only lands rewetted since 1990 (with generally positive effects for the climate) and lands newly drained since 1990 (a marginal acreage) are entering the accounting.

- The epithet "direct human-induced" implies that emission reductions as a result of spontaneous rewetting (e.g. by beaver dams, subsidence or clogging ditches) cannot be accounted for. 
- The complex definition of "rewetting' was politically necessary because some countries wanted to prevent the inclusion of hydro-electricity and other reservoirs with their (sometimes huge) methane emissions. Various NorBalWet countries have large tracks of such inundated peatlands, e.g. Finland, Russia, and Iceland. The definition now excludes "flooded land', as rewetting is defined as the partial or total reversal of drainage, and drainage as the lowering of the soil water table. This phrasing implies that the activity concerns land that was 'wet', subsequently has been drained, and now is made wet again. Areas that are flooded but never have been drained thus do not fall under 'rewetting'. Also drained areas that have been flooded to the extent that the mean water level to the surface and the water level fluctuations by far exceed that of the area before drainage, do not comply with the activity.

The rules and regulations of the UNFCCC with respect to rewetting of drained and the protection of undrained peatlands are rather complex (table 3.1). The Intergovernmental Panel for Climate Change (IPCC) has meanwhile produced extensive guidance how to report and account for these peatland emissions (IPCC 2014a, 2014b). Table 3.1 also illustrates how climate change mitigation action in the context of the Ramsar Convention may interfere with the rules of the Kyoto Protocol.

"Wetland drainage and rewetting" allows accounting for rewetting of peatlands that currently fall outside other mandatory and voluntarily elected activities. The activity has deliberately been created to allow a "hotspot approach" for peatland rewetting, as long as no complete wallto-wall land-based accounting has been achieved or not all art. 3.4 activities have become mandatory. 
Table 3.2: Practices of peatland rewetting and drainage and the LULUCF Activities under which these practices have to be accounted in the second commitment period of the Kyoto Protocol (2013-2020)

\begin{tabular}{|c|c|c|}
\hline Land use practice & $\begin{array}{l}\text { To be accounted } \\
\text { under }\end{array}$ & $\begin{array}{l}\text { Type of } \\
\text { accounting }\end{array}$ \\
\hline $\begin{array}{l}\text { Felling and drainage of a forest on organic soil and conversion to } \\
\text { cropland or grassland. } \\
\text { Forest harvesting that by reduced evapotranspiration results in so } \\
\text { much higher water tables that re-establishment of forest is prevented. } \\
\text { Rewetting that raises the water table to such an extent, that forest } \\
\text { cannot persist or regenerate. } \\
\text { Rewetting and felling of forest, e.g. to restore a non-forested peat- } \\
\text { land. }\end{array}$ & Deforestation* & Gross-net \\
\hline $\begin{array}{l}\text { Drainage of a (non-forested) peatland for forestry, e.g. when a treeless } \\
\text { or sparsely treed peatland is drained to stimulate tree growth. } \\
\text { Rewetting of a (non-forested) peatland for forestry, e.g. when a } \\
\text { grassland on organic soil is rewetted and afforested with Alder trees. }\end{array}$ & $\begin{array}{l}\text { Afforestation / } \\
\text { Reforestation* }\end{array}$ & Gross-net \\
\hline $\begin{array}{l}\text { Drainage of forest on organic soil that remains a forest, e.g. when a } \\
\text { forested peatland is drained to stimulate tree growth. } \\
\text { Rewetting of forest on organic soil that remains a forest, e.g. when } \\
\text { an Ash forest on organic soil is rewetted and replaced by an Alder } \\
\text { forest. }\end{array}$ & $\begin{array}{l}\text { Forest } \\
\text { Management* }\end{array}$ & $\begin{array}{l}\text { (Forward } \\
\text { looking) } \\
\text { Reference } \\
\text { level }\end{array}$ \\
\hline $\begin{array}{l}\text { Drainage of a non-forested peatland and conversion to cropland. } \\
\text { Rewetting of a cropland on organic soil that remains a cropland, e.g. } \\
\text { when a potato field is rewetted for paludiculture. }\end{array}$ & $\begin{array}{l}\text { Cropland } \\
\text { Management } \\
\text { (if elected) }\end{array}$ & Net-net \\
\hline $\begin{array}{l}\text { Drainage of a non-forested peatland to improve grazing. } \\
\text { Rewetting of a grassland on organic soil that remains a grassland, e.g. } \\
\text { when a drained grassland used for dairy cow husbandry is rewetted to a } \\
\text { grassland for water buffalo husbandry. }\end{array}$ & $\begin{array}{l}\text { Grazing Land } \\
\text { Management } \\
\text { (if elected) }\end{array}$ & Net-net \\
\hline $\begin{array}{l}\text { Revegetation and rewetting of a (non-forested) peatland, e.g. when a } \\
\text { bare peat extraction site is converted to a vegetated wetland. }\end{array}$ & $\begin{array}{l}\text { Revegetation } \\
\text { (if elected) }^{\#}\end{array}$ & Net-net \\
\hline $\begin{array}{l}\text { Rewetting or drainage (after 1990) of a (non-forested) peatland that is } \\
\text { not yet accounted for under any other mandatory or elected activity. }\end{array}$ & $\begin{array}{l}\text { Wetland Drainage } \\
\text { and Rewetting } \\
\text { (if elected) }\end{array}$ & Net-net \\
\hline
\end{tabular}

* mandatory accounting; \# mandatory accounted if elected in the first commitment period. Mind that several land use associated GHG fluxes additionally have to be accounted under the sectors Agriculture, Energy, Industrial Processes, and Waste.

\section{Synergies and cooperation}

In preparation for UNFCCC COP5 (1999), the Ramsar Secretariat commissioned IUCN to prepare a technical document to explore collaboration between the Ramsar Convention and the UN Framework Convention on Climate Change. The paper was distributed to the UNFCCC's Subsidiary Body for Scientific and Technological Advice (SBSTA) and to delegates to its COP5.

As a result SBSTA "requested the secretariat [of UNFCCC] to liaise with the secretariat of the Convention on Wetlands ... in order to determine how cooperation between the conventions could be strengthened." 
In Resolution VIII.3 Climate change and wetland's (2002), the Ramsar COP requested the Ramsar STRP to work further with the UNFCCC and the Intergovernmental Panel on Climate Change (IPCC) on the relationships between wetlands and climate change. Except for the important resolutions mentioned in chapter 1 of this report, this has not resulted in active participation of the Ramsar Convention in the peatland and climate discussions in the UNFCCC, as is illustrated by the limited participation of the Ramsar Secretariat in the major UNFCCC meetings. Instead the Ramsar associated NGO Wetlands International has actively pushed the peatland issue in the UNFCCC (Joosten 2011).

\section{Topical developments and initiatives}

In 2012 the UNFCCC has decided to prolong the Kyoto Protocol, in spite of some important peatland countries stepping completely out (Canada) or taking no commitments for the second commitment period (New Zealand, Japan and Russia).

The other NorBalWet countries have to decide which voluntary activities they will choose to account for. For all countries Forest Management will be mandatory, including for Estonia and Iceland that until now had refrained from accounting this activity. Denmark has to continue accounting for Cropland Management and Grazing land Management, which opens good perspectives for rewetting of cropland and grassland on peat, i.e. the major peatland emitters in that country. Iceland has to continue its accounting for Revegetation.

As part of the agreement on LULUCF accounting in the second commitment period of the KP, Parties agreed to explore more comprehensive accounting of GHG fluxes from LULUCF. To date discussions have not produced any significant outcome on this issue. In recent discussions (SBSTA 39), it was agreed that any outcome will not be applicable in the second commitment period, but would only be valid after 2020 (see http://unfccc.int/resource/docs/2013/sbsta/eng/05.pdf).

From a peatland conservation and climate perspective, it would be best if countries that refrain from choosing the entire package of activities would choose Wetland Drainage and Rewetting. This would, without major risks for compliance and excessive monitoring allow to stimulate peatland rewetting. As most NorBalWet countries are members of the European Union, national policies may have to be coordinated with EU policies (see section 3.6).

For the longer term, the architecture of the post-2020 treaty will be decisive, as this will set the course for climate associated peatland conservation and restoration in the decades to come. 
Currently intensive discussions are taking place in and outside UNFCCC on the role of the land sector in this post 2020 scheme (e.g. La Vina et al. 2012, Canaveira 2013, Estrada et al. 2014, Iversen et al. 2014, Von Unger et al. 2014), a discussion in which the Nordic Council of Ministers is actively involved (Parker et al. 2014). Most contributions stress the importance of including peatland emissions and peatland rewetting/restoration. La Vina et al. (2012) see in a mandatory accounting system for the entire land-use sector, including peatland, a way to "ensure the highest level of environmental integrity" and to close perceived loopholes in LULUCF, including those of cultivating "biofuels" on drained peatland (cf. Couwenberg 2007).

The negotiation of the future climate treaty presents an opportunity to improve the current system of land sector accounting that indeed over the years has become increasingly complex and characterized by conflictive fragmentation (cf. table 3.1). Given the division of land use issues across dozens of separate negotiation streams, there is, however, a risk that the confusing situation will be carried forward to the new climate treaty.

The development of "a protocol, another legal instrument or an agreed outcome with legal force under the Convention applicable to all Parties" (UNFCCC decision 1/CP.17) is a major challenge. With respect to the land sector, the disproportionally large emissions from drained peatland offer an excellent opportunity to implement a hot spot approach for peatlands as a first step toward the full coverage of land. In contrast to carbon sequestration in forest management, the emission reduction associated with peatland rewetting can be considered "permanent" (Von Unger et al. 2014), which avoids the complex discussions about "nonpermanence", i.e. the risk of emission reductions are reversed, and the buffer-mechanisms necessary to cope with this risk. Furthermore peatland rewetting is, certainly when it is combined with paludiculture as a subsequent land use, a good example of the integration of climate change mitigation and adaptation.

An initial hot spot approach has the big advantage that the efforts of MRV (Measuring, Reporting, Verification) can be concentrated on areas, where a disproportional reduction of emissions reductions and a fair "return-on-investment" can be achieved. As countries with a large experience in the MRV of abundant domestic peatlands, the NorBalWet countries may play an important role in disseminating technology and building capacity in other parts of the world. 
Last but not least, a stronger involvement of Ramsar in the UNFCCC discussions on a national and international level would be instrumental in counterbalancing the very strong forest bias that prevails in UNFCCC land sector thinking. In this respect, UNFCCC will certainly benefit from stronger participation of peatland oriented persons and organisations including the Ramsar Convention.

\subsection{The Convention on Biological Diversity (CBD)}

\section{Peatlands, climate and the Biodiversity Convention}

Peatlands were firstly brought on the agenda at the Convention on Biological Diversity (CBD) in 2004 by adoption of CBD resolution VII/15, mentioning peatlands as valuable ecosystems as habitats and for carbon storage and sequestration. In the following years, a team of peatland experts coordinated by Wetlands International and the Global Environment Centre produced the global "Assessment on Peatlands Biodiversity and Climate Change" (Parish et al. 2007, 2008). This Assessment was endorsed by the CBD's Subsidiary Body on Scientific, Technical and Technological Advice (SBSTTA) in July 2007. In May 2008, CBD COP 9 in its decision on Biodiversity and Climate Change recognized "the importance of the conservation and sustainable use of the biodiversity of wetlands and, in particular, peatlands in addressing climate change". The decision noted "with appreciation the findings of the global Assessment on Peatlands, Biodiversity and Climate Change" and encouraged Parties and other Governments to strengthen collaboration with the Ramsar Convention and to implement the Ramsar Guidelines for Global Action on Peatlands and the actions listed in the global Assessment.

Whereas not specifically focusing on peatlands, the Strategic Goals and Aichi Targets adopted by CBD's COP10 (Nagoya, Japan, 2010, Decision $\mathrm{X} / 2$ ) are of special relevance for peatland conservation and restoration for climate change mitigation, specifically:

- Target 5: "By 2020, the rate of loss of all natural habitats, including forests, is at least halved and where feasible brought close to zero, and degradation and fragmentation is significantly reduced."

- Target 11: "By 2020, at least $17 \%$ of terrestrial and inland water, and $10 \%$ of coastal and marine areas, especially areas of particular importance for biodiversity and ecosystem services, are conserved through... protected areas and other effective area based conservation measures." 
- Target 14: "By 2020, ecosystems that provide essential services, including services related to water, and contributed to health, livelihoods and well-being, are restored and safeguarded."

- Target 15: "By 2020, ecosystem resilience and the contribution of biodiversity to carbon stocks have been enhanced, through conservation and restoration, including restoration of at least 15 per cent of degraded ecosystems, thereby contributing to climate change mitigation and adaptation and to combating desertification."

Especially Target 15 raises the question what "degradation" is: what degradation is from one perspective may be seen as progress from the other. A forester may have a different view from a conservationist looking at a forestry drained peatland. Clearly a forestry drained peatland is a degraded mire ecosystem and a lost natural habitat, but do the Aichi targets indeed imply that some $2,500,000$ ha $(=15 \%)$ of the peatlands drained for agriculture, forestry and peat extraction in the NorBalWet countries (incl. the European part of Russia) have to be restored by 2020 ?

Anyhow the Aichi targets provide ample opportunity to find synergies in the field of peatland rewetting and restoration for the benefit of climate change mitigation. In this respect it is advisable to strengthen synergies between the Ramsar and Biodiversity Conventions on a national scale.

\section{Synergies between the Ramsar and Biodiversity Conventions on peatlands}

In January 1996, the secretariats of the Ramsar Convention and the CBD signed a first Memorandum of Cooperation, and in November of the same year the CBD's COP3 invited Ramsar to cooperate as a lead partner in implementing CBD activities related to wetlands. Accordingly a Joint Work Plan 1998-1999 between the two conventions was developed and implemented, followed by further joint working plans. The Ramsar Convention is the CBD implementing body on the thematic area Inland Waters and does also cover coastal areas to a water depth of about $6 \mathrm{~m}$. The COPs of both conventions have also called for increased communication and cooperation between their subsidiary scientific bodies, the CBD's Subsidiary Body for Scientific, Technical, and Technological Advice (SBSTTA) and the Ramsar Scientific and Technical Review Panel (STRP), and members of both of these bodies regularly participate in the work and meetings of one another. 
Cooperation in the field of climate change mitigation was first phrased by the CBD in its COP7 (Kuala Lumpur 2004) that noted „that there are opportunities to implement climate change mitigation and adaptation activities in ways that are mutually beneficial and synergistic, and that contribute simultaneously to the United Nations Framework Convention on Climate Change, the Convention on Biological Diversity, the United Nations Convention to Combat Desertification, the Vienna Convention for the Protection of the Ozone Layer, the Ramsar Convention on Wetlands, and other international agreements, all within broader national development objectives."

\subsection{UNESCO World Heritage Convention}

\section{Peatlands and the World Heritage Convention}

The World Heritage Convention links together the concepts of nature conservation and the preservation of cultural properties. The Convention recognizes the way in which people interact with nature, and the fundamental need to preserve the balance between the two.

Pristine peatlands are ecosystems with an incomplete cycling of material and a consequent continuous accumulation of organic material. They record their own history and that of their wide surroundings in systematic layers, making them particularly suited to the reconstruction of long-term human and environmental history. The data stored in the peat archives include macro-remains of peat-accumulating plants, pollen and spores of plants, fungi and algae, including those from the wider surrounding areas and all sorts of materials and substances that one way or another got into the peat, including archaeological objects. These important archives are safe as long as the peats remain water saturated. This value has been recognized by Ramsar Resolution VIII.19: "Guiding principles for taking into account the cultural values of wetlands for the effective management of sites" (2002).

In its "Strategy for the Heritage Management of Wetlands" (2001) the European Archaeological Council has drawn attention to the importance of wetlands for the preservation of cultural features, and argued that there is much common ground in the wetland biodiversity and cultural heritage management of peatlands (http://ramsar.rgis.ch/cda/fr/ramsar-newsarchives-2001-wetlands-and-cultural-19140/main/ramsar/1-26-45-88\% 5E19140_4000_1_). 


\section{Synergies between the Ramsar and World Heritage Conventions with respect to peatlands}

A Memorandum of Understanding was signed between the Ramsar Secretariat and the World Heritage Centre in May 1999 in order to promote nominations of wetland sites under the two conventions, to coordinate reporting about shared sites, and to encourage the establishment of joint national committees (http://archive.ramsar.org/cda/ en/ramsar-documents-mous-ramsar-mou-with-the/main/ramsar/1-31115\%5E21517_4000_0_).

Examples of areas with peatland that are shared (sometimes partly) by the Ramsar and the World Heritage Conventions include in Europe, for example, the Madriu-Perafita-Claror Valley (Andorra), Srébarna (Bulgaria) and the Danube Delta (Romania), whereas globally Peace-Athabasca Delta/Whooping Crane Summer Range/Wood Buffalo National Park (Canada), Gough and Inaccessible Islands (British overseas territory) and the Everglades National Park (USA) can be mentioned as examples.

For the Nordic-Baltic countries, Sweden is the only country with overlapping peatland containing Ramsar and World Heritage sites: Sjaunja and Laidaure became Ramsar sites in 1974, whereas the area was designated a World Heritage Site in 1996 under the name Laponian Area.

\subsection{Climate initiatives for peatlands from the UN Food and Agriculture organisation}

Since 2011 the Food and Agricultural Organisation of the United Nations FAO has started to pay more attention to peatlands in the framework of its MICCA (Mitigation of Climate Change in Agriculture) programme (www.fao.org/climatechange/micca/peat/en/). The FAO recognizes that agriculture and forestry are the main drivers of peatland drainage worldwide, but that peatland drainage - through huge GHG emissions and subsidence associated land loss - is in turn frustrating the aims of a sustainable provision of food, fodder, fiber and fuel (fig. 3.3.). 
Fig. 3.3: The unworkable gears of drained peatland utilization

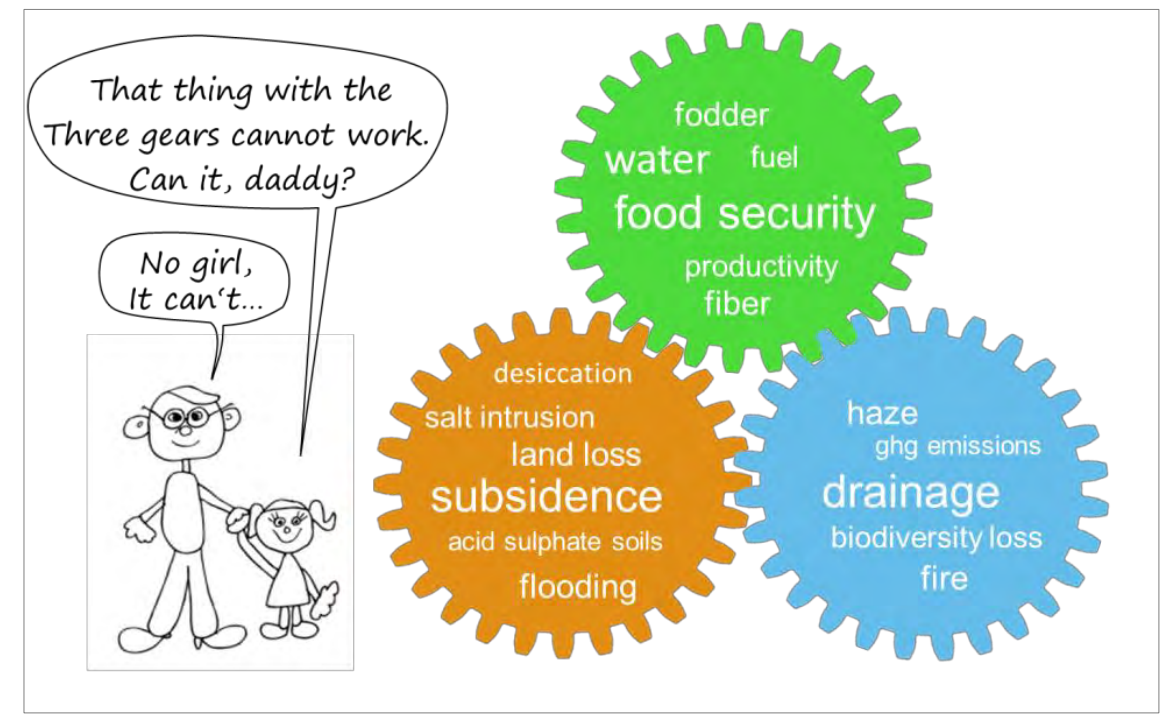

Joosten et al. 2012.

In 2012 FAO produced the report "Peatlands - guidance for climate change mitigation through conservation, rehabilitation and sustainable use" (Joosten et al. 2012), that identified 10 elements of strategic action:

1. Identify occurrence and status (pristine, drained, abandoned, under productive use) of all peatland worldwide.

2. Improve assessment of greenhouse gas emissions from peatlands. Improve methodologies for measuring, reporting and verifying (MRV).

3. Conserve all reasonably intact peat swamps.

4. Prevent further degradation of already degraded peatlands including:

- no further intensification of artificial drainage in already drained areas

- installation of hazard monitoring and mitigation schemes to avoid and restrain uncontrolled fires and soil erosion

- no further expansion of agricultural practices that require drainage (swap drained land use on peat, e.g. oil palm and pulpwood plantations, to mineral soils and apply paludiculture)

- no further uncontrolled selective nor illegal logging. 
5. Restore degraded peatlands by rewetting, reforestation (in the tropics) and subsequent conservation and/or paludiculture. Restoration of peatlands reduces emissions, improves water regulation, benefits biodiversity and opens other income options.

6. Target financial resources to peatland conservation, restoration and better management.

7. Stimulate and apply existing and developing climate financing mechanisms on the compliance market (Kyoto Protocol, REDD+, NAMA's), the voluntary market (private sector investment in peatland rehabilitation) and from other sources.

8. Support local communities at the earliest stage and stimulate community development to overcome their opportunity costs and dependence on unsustainable peatland use.

9. Ensure that GHG criteria are integrated in credible certification and subsidy schemes for products that are derived from drained peatlands, including biofuels, palm oil, pulp wood, and other products from agriculture, horticulture and forestry. Each country that imports such products should review domestic policies for this.

10.Share experiences and expertise on peatland conservation, restoration and better management among countries rich in peatlands and organic soils - especially with those in need of capacity building.

A new FAO report on the technical options for climate responsible peatland utilization has been published in August 2014 (Biancalani \& Avagyan 2014).

\subsection{Climate initiatives for peatlands under the European Union}

\section{Introduction}

The majority of the NorBalWet countries are member states of the European Union, so it is useful to acknowledge the various EU rules and directives of relevance to peatlands and climate and to explore the possible synergies with other policy fields, including the conservation of biodiversity, and nutrient and flood retention (cf. Joosten et al. 2013). 


\section{EU domestic climate policy with respect to LULUCF}

Following the embrace of the new Kyoto Protocol activity Wetland Drainage and Rewetting at UNFCCC COP 17 (Durban), the EU aligned its own LULUCF accounting rules with the new international standard and adopted Decision No. 529/2013/EU of 21 May 2013. Under the EU new rules, accounting for greenhouse gas fluxes from Cropland Management (CM) and Grazing land Management (GM) shall become mandatory from 2021 onwards. Accounting for GHG fluxes from Wetland Drainage and Rewetting (WDR) remain voluntary with Parties given the opportunity to prepare and maintain annual accounts to reflect GHG fluxes from this activity. In the decision's recitals, the EU calls the new accounting rules "a first step towards the inclusion of [CM and GM] activities in the Union's emission reduction commitment". With respect to peatlands, the recitals continue, "the Union should endeavour to advance the issue at the international level with a view to reaching an agreement within the bodies of the UNFCCC or of the Kyoto Protocol on the obligation to prepare and maintain annual accounts" for Wetland Drainage and Rewetting, "with a view to including this obligation in the global climate agreement to be concluded no later than 2015."

Despite the voluntary nature of Wetland Drainage and Rewetting accounting, this new decision effectively imposes mandatory accounting for most rewetting activities, as $90 \%$ of the drained peatlands are drained for agriculture (and thus fall under Cropland or Grazing land Management) or forestry (for which all activities since 2013 already have to be mandatorily accounted under the Kyoto Protocol). WDR accounting proper would virtually cover little more than rewetting of current and former peat extraction sites.

There is a notable absence of LULUCF in the European Union's emissions trading schemes, the EU Emissions Trading Scheme (EU ETS) and the trading scheme under the Effort Sharing Decision (ESD) and it is unclear whether this situation will change in the near future (for more detail, see Von Unger et al. 2014).

\section{EU Common Agricultural Policy (CAP)}

As shown in chapters 2 and 3, peatland agriculture is responsible for the vast majority of emissions from peatlands in the NorBalWet countries. The Common Agricultural Policy (CAP) is the cornerstone of EU policy making in agriculture. On 16 December 2013 the Council of EU Agriculture Ministers formally adopted the four Basic Regulations for the reformed CAP as well as the Transition Rules for 2014 (see summary under http://ec.europa.eu/ agriculture/policy-perspectives/policy-briefs/05_en.pdf). 
The CAP includes the EU's largest subsidy scheme, totalling over 400 billion euro for the period 2014-2020, of which over 75\% is directed towards direct payments under the so called First Pillar. The crosscompliance mechanism of Pillar I ties direct payment support for farmers to compliance with standards of environmental care. Farmers are, among others, required to avoid the deterioration of the habitat, maintain soil organic matter and protect and manage water. Non-compliance should lead to reductions in subsidy and development payments. However, the soil organic matter criterion of the cross-compliance regime only matches mineral soils, so that the climate hostile agriculture on deeply drained peat (see chapter 2) still receives unrestricted EU direct payments.

The focus of the Second Pillar on sustainability includes voluntary measures that are beneficial for the environment and the climate. At least 30\% of the budget of each Rural Development programme must be reserved for agri-environmental climate measures, organic farming, Areas of Natural Constraints (ANC), Natura 2000 areas, forestry measures and investments which are beneficial for the environment or the climate. In this way the Second Pillar may become a strong incentive for peatland conservation and restoration.

\section{EU Habitats Directive}

The Habitats Directive (together with the Birds Directive) forms the cornerstone of Europe's nature conservation policy. It is built around two pillars: the Natura 2000 network of protected sites and the strict system of species protection. The Habitats Directive protects over 1,000 animal and plant species and over 200 "habitat types" of European importance, under which a wide variety of mire and peatland types. The Habitats Directive has a target that natural habitats and species of European interest should be maintained or restored at favourable conservation status, but it does not give a timetable when this target should be reached. Moreover, several species covered by Annex 1 of the Birds Directive use peatlands as a primary habitat.

In the first EU wide assessment (2001-2006, ETC/BD 2008)75\% of the wetland habitat types and more than $60 \%$ of the wetland species targeted by the Habitats Directive were reported as of unfavourable conservation status. These results have been taken into account in the EU Biodiversity Strategy to 2020. This Strategy sets midterm goals in its Target 1: "To halt the deterioration in the status of all species and habitats covered by EU nature legislation and achieve a significant and measurable improvement in their status so that, by 2020 , compared to current assessments: (i) 100\% more habitat assessments and 50\% more species assessments under the Habitats Directive show an improved 
conservation status; and (ii) 50\% more species assessments under the Birds Directive show a secure or improved status." The Strategy also includes a "restoration subtarget" to restore at least 15\% of degraded ecosystems. A new EU wide assessment will be completed in 2015 based on the 2007-2012 reporting cyclus.

\section{EU Water Framework Directive}

The EU Water Framework Directive (WFD) has a clear link to "waterdependent Natura 2000 sites" requesting them to be part of a register of protected areas (WFD Art 6). However, the target to reach favourable conservation status under the Habitats Directive is not only limited to habitat types and species occurring in the Natura 2000 sites, but also in the wider countryside because it is assessed at national biogeographical level. This is why the WFD, which covers all surface waters and groundwater, can- if adequately implemented - significantly support reaching the target for wetland species and habitat types.

The purpose of the EU Water Framework Directive is to establish a framework for the protection of inland surface waters, transitional waters, coastal waters and groundwater which prevents further deterioration and protects and enhances the status of aquatic ecosystems and, with regard to their water needs, terrestrial ecosystems and wetlands directly depending on the aquatic ecosystems.

Mires and peatlands are (semi-)terrestrial ecosystems with distinct water needs which encompass (and often directly depend on) aquatic ecosystems. Through Article 1 mires and peatlands are protected by the Water Framework Directive against further deterioration.

Secondly, wetland restoration is explicitly suggested as a supplementary measure for the programme of measures.

In various regions of the EU, including in NorBalWet countries, there it is a general need to reduce the nitrogen and phosphorus pollution into water courses, lakes and coastal waters in order to reach the target of the Directive. The Directive explicitly refers to the restoration of wetlands, which includes rewetting of peatlands, as a possible means to reach the nutrient target values.

In contrast to anthropogenically modified and drained peat soils, near-natural mires mostly have a beneficial effect on the local nutrient and water balance. Natural mires act often as nutrient sinks. In contrast, drained peatlands have short flow paths and a decomposing peat body, which increases nutrient pollution of surface waters. The former function as a nutrient sink can be partially restored if the water table is raised. In this way rewetted mires contribute to the implementation of European targets in water pollution control. 


\section{HELCOM}

HELCOM (Baltic Marine Environment Protection Commission - Helsinki Commission) is the governing body of the Convention on the Protection of the Marine Environment of the Baltic Sea Area, known as the Helsinki Convention. HELCOM was established to protect - through intergovernmental cooperation - the marine environment of the Baltic Sea from all sources of pollution. The Contracting Parties (Denmark, Estonia, the European Union, Finland, Germany, Latvia, Lithuania, Poland, Russia and Sweden) cover the majority of the NorBalWet countries (fig. 3.4.).

The HELCOM Baltic Sea Action Plan is an ambitious programme to restore the good ecological status of the Baltic marine environment by 2021. Peatland rewetting is one of the options that have been adopted by various member states to reduce the emission of nitrogen and phosphorous to the Baltic Sea.

Fig. 3.4: Contracting parties of HELCOM and the catchment area of the Baltic Sea

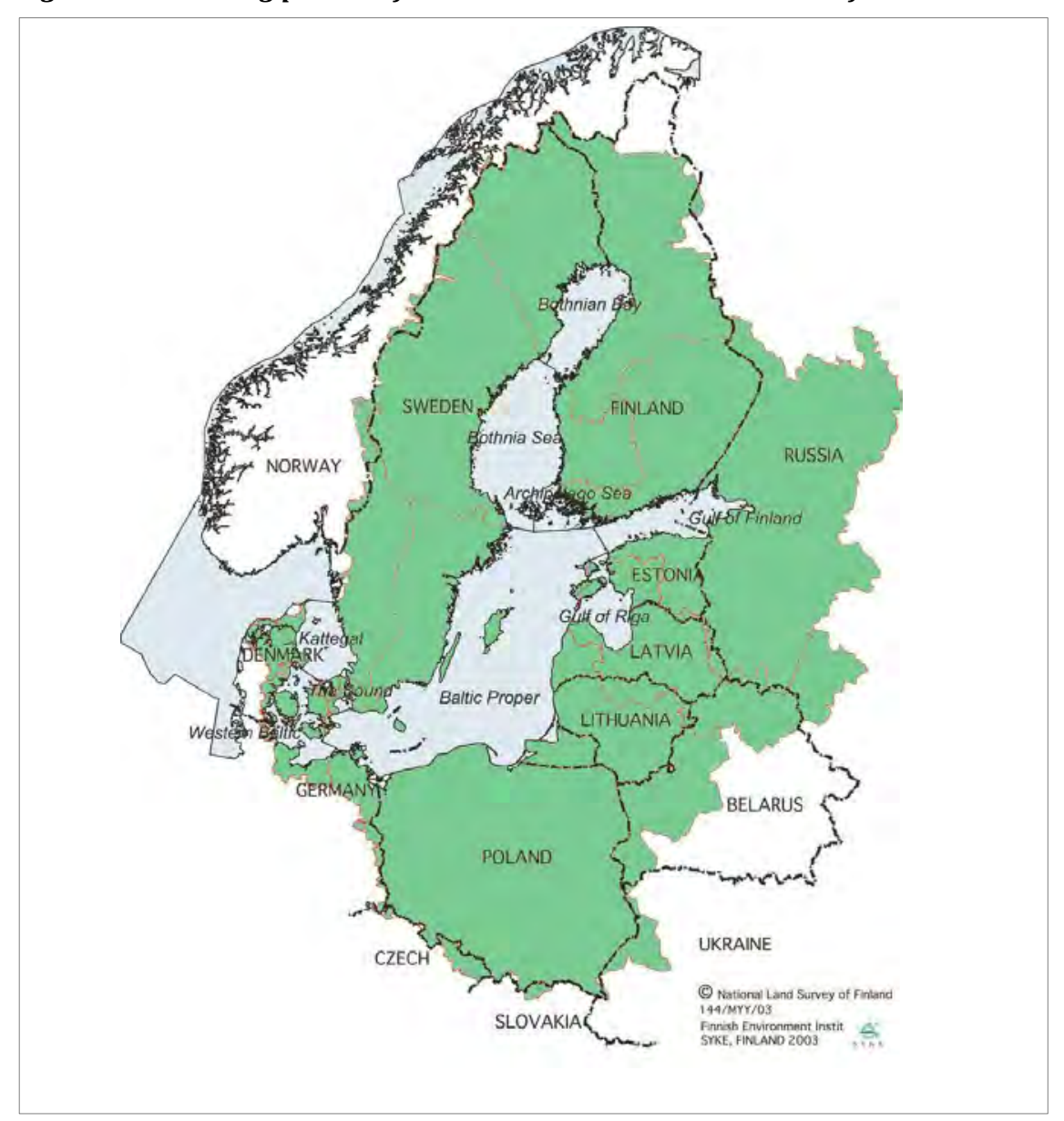




\section{Conclusions}

Many rules and regulations support the options of the Ramsar Convention to protect and restore peatlands for the benefit of climate change mitigation. Especially the "wise use" concept of the Ramsar Convention may provide an important bridge between these initiatives. Both on an international and a national level cooperation between these initiatives will provide synergies, that will benefit from the wetland and peatland expertise of the Ramsar Convention in general and the NorBalWet countries in particular. 



\section{Climate change mitigation and adaptation as criteria for Ramsar site designation}

\subsection{Introduction}

In 2013 Denmark designated the raised bog of Lille Vildmose as Wetland of International Importance while for the first time in the history of the Convention explicitly applying the Ramsar criterion on climate regulation.

This chapter analyses the arguments used for this designation and explores the options offered by Ramsar Handbook 17 (4th edition) and similar criteria to designate peatlands as Wetlands of International Importance on the basis of climate change mitigation.

\subsection{The designation of Lille Vildmose}

\section{Characterization of Lille Vildmose}

Lille Vildmose is a peatland complex with one of the largest areas of active raised bog in lowland Northwest Europe. Next to 2,022 ha of active raised bog, the area contains 252 ha of degraded raised bogs still capable of natural regeneration, 1,246 ha of degraded peatland under restoration, 400 ha of bog woodland, and 1,000 ha of old natural forest of high biodiversity on mineral soil. Peat extraction up to 2011 has reduced the area of active raised bog from originally 5,500 ha to currently 2,022 ha. In a few small areas peat extraction continues. At present a large central part of Lille Vildmose is drained and partly cultivated. Plans for restoring bog habitat in this area are now being implemented through support from EU LIFE+ (www.LIFELilleVildmose.dk).

The Ramsar site is part of a 7,513 ha large area protected under Danish nature conservation law and for a large part protected under article 3 of the Danish Nature Protection Act, which generally protects fens, bogs, meadows and heathland larger than $2,500 \mathrm{~m}^{2}$ and lakes larger than $100 \mathrm{~m}^{2}$. The delineation of the Lille Vildmose Ramsar site follows the boundary of the Special Protection Area for Birds (SPA) under the 
EEC Birds Directive in the Natura 2000 area no. 17 Lille Vildmose, Tofte Skov og Høstemark Skov. This area is also a Special Area of Conservation under the EEC Habitats Directive.

- (From the Information Sheet on Ramsar Wetlands Lille Vildmose, Denmark, completed 16 May 2013): https://rsis.ramsar.org/ RISapp/files/RISrep/DK2166RIS.pdf (but outside hyperlink).

\section{Justification of the designation}

The designation of Lille Vildmose as Wetland of International Importance is centred on two criteria that on the basis of the Information Sheet can be summarized as follows:

1. The peatland sequesters and stores carbon in amounts that are relevant for the regional climate. The peatland currently sequesters 6,780 (medium value) to $8,942 \mathrm{t} \mathrm{CO}_{2} \mathrm{yr}^{-1}$ (high value). These values are expected to increase to $11,983-14,055 \mathrm{t} \mathrm{CO}_{2} \mathrm{yr}^{-1}$, respectively, after restoration of the degraded areas. Furthermore the already existing peat body stores a substantial amount of carbon, e.g. solely in the southern and central parts of Tofte Mose already some 4.5 million ton of C ( $4.5 \mathrm{~m}$ thick $\mathrm{x} 2,000$ ha $\mathrm{x} 0.1$ dry peat weight $\mathrm{x} 0.5$ carbon content).

2. The bog comprises large areas of threatened plant communities that have severely declined in distribution and extent in the relevant biogeographic region as a result of large-scale peat extraction and agricultural reclamation. The site holds important flora and fauna characteristic of large bogs, including Sphagnum mosses (including Sphagnum magellanicum, S. papillosum, $S$. rubellum, $S$ tenellum, $S$. austinii and S. fuscum), Drosera intermedia, Rhynchospora alba, Rubus chamaemorus and Scheuchzeria palustris. Threatened breeding birds include Common Crane, Curlew, Golden Eagle, White-tailed Eagle, Eagle Owl, Avocet and most likely Wood Sandpiper.

\section{Analysis of the criteria used for designation}

Beyond any doubt Lille Vildmose deserves - as probably the largest area of active raised bog in lowland Northwest Europe - a designation as Wetland of International Importance under the Ramsar Convention. 
With respect to the climate regulation criterion, the following remarks can be made:

- The climate regulation function of peatlands has to take the full set of greenhouse gas fluxes into account. Whereas mires are generally net carbon sinks, their net effect on the climate also depends on their methane emission characteristics and the timeframe under consideration (see chapter 2). By limiting quantification to the $\mathrm{CO}_{2}$ sequestration capacity, the designation largely neglects the methane flux that is inherent to mires.

- An adequately protected pristine mire does not contribute to climate change mitigation:

- The $\mathrm{CO}_{2}$ sequestration of a living mire was already part of the world's greenhouse balance long before the anthropogenic rise of atmospheric $\mathrm{CO}_{2}$-levels. To compensate for additional emissions, like those from burning fossil fuels, additional sinks have to be created (while appreciating existing sinks).

- Mire protection only leads to climate change mitigation, if emissions are effectively avoided, i.e. if without protection the carbon from the mire would be mobilized by expanding drainage. In case of well-protected mires, this scenario is unrealistic.

- To contribute to climate change mitigation, drained peatlands have to be rewetted (as is indeed happening in Lille Vildmose).

- Greenhouse gas fluxes have no direct relevance for the regional climate. As gases in the atmosphere are within a few days distributed across the globe, it is inconsequential where on Earth emissions or emission reductions take place. The effect of greenhouse gas emissions on the regional climate is only determined by the way the global climate affects the regional climate. As such, the protection of an equivalent peatland area in Indonesia would have the same effect on the regional climate around Lille Vildmose as does the protection of Lille Vildmose itself.

- Indeed a regional climate effect of mires and peatlands does exist, but this depends on evapotranspiration, not on greenhouse gas fluxes. In a wet mire more solar radiation energy is used for evaporation and less for heating the atmosphere than in a drained peatland. The regional climate effect of a peatland is a function of water availability, the direct influence of vegetation on the radiation 
balance (e.g. via the albedo), and the heat conduction capacity of the peat soil (Joosten et al. 2013).

- The GHG fluxes for Lille Vildmose have to be updated as the data on the information sheet are nearly 10 years old. In the last decade a substantial body of new data on GHG fluxes from peatlands has been gathered. Calculation with the latest IPCC (2014) default values arrives at current and expected net emissions of 17,780 and 7,294 $\mathrm{CO}_{2}$-eq. $\mathrm{yr}^{-1}$, respectively (tables 5.1 and 5.2).

- According to these figures Lille Vildmose is and will remain (though with much smaller fluxes due to rewetting) a net greenhouse gas emitting ecosystem, in spite of the carbon sequestration taking place.

- The calculated fluxes from Lille Vildmose represent c. $1 \%$ of the total Danish peatland emissions and c. $0.02 \%$ of the total net anthropogenic emissions of Denmark in 2012 (latest NIR). The estimated carbon content in the total peat of Lille Vildmose is estimated to be approximately $10 \%$ of the total peat carbon volume of 73.6 Mton in Denmark (Joosten 2009).

Whereas an effect of greenhouse gas emissions and carbon storage on the regional climate cannot reasonably be defended, the question remains whether global climate change mitigation could constitute a sensible criterion for identifying Wetlands of International Importance. This question is explored in the following section.

\begin{tabular}{|c|c|c|c|}
\hline Land type & ha & $\begin{array}{r}\text { Emission Factor } \\
\text { (ton } \mathrm{CO}_{2}-\mathrm{e} \mathrm{ha-1} \mathrm{yr}^{-1} \text { ) }\end{array}$ & $\begin{array}{l}\text { Total emissions } \\
\left(\text { ton } \mathrm{CO}_{2} \text {-e } \mathrm{yr}^{-1} \text { ) }\right.\end{array}$ \\
\hline active raised bog & 2,022 & 0 & 0 \\
\hline degraded raised bog capable of regeneration & 252 & 10 & 2,520 \\
\hline degraded peatland under restoration & 1,246 & 10 & 12,460 \\
\hline bog woodland & 400 & 7 & 2,800 \\
\hline Total & & & 17,780 \\
\hline
\end{tabular}

Table 5.2: Indicative GHG emissions of Lille Vildmose after successful restoration (emission factors according to IPCC 2014a including the sum of $\mathrm{CO}_{2}, \mathrm{CH}_{4}$ and $\mathrm{N}_{2} \mathrm{O}$ )

\begin{tabular}{lrrr} 
Land type & ha & $\begin{array}{r}\text { Emission Factor } \\
\text { (ton } \mathrm{CO}_{2}-\mathbf{e ~ h a ~}^{-1} \mathbf{~ y r}^{-1} \text { ) }\end{array}$ & $\begin{array}{r}\text { Total emissions } \\
\text { (ton } \mathrm{CO}_{2}-\mathbf{e} \mathbf{~ y r}^{-1} \text { ) }\end{array}$ \\
active raised bog & 2,022 & 0 & 0 \\
regenerated degraded raised bogs & 252 & 3 & 756 \\
restored degraded peatland & 1,246 & 3 & 3,738 \\
bog woodland & 400 & 7 & 2,800 \\
Total & & & 7,294 \\
\hline
\end{tabular}




\subsection{Identifying Wetlands of International Importance for global climate change mitigation}

\section{Introduction}

One of the main instruments of the Ramsar Convention is the designation of Wetlands of International Importance (Ramsar Sites). Throughout its evolution, the Convention has developed extensive designation criteria. These criteria have been kept under constant review, which has culminated in the present Ramsar Handbook 17: "Designating Ramsar Sites" (Ramsar Handbooks $4^{\text {th }}$ edition 2010) that integrates the outcomes of relevant resolutions and experiences to date.

This paragraph explores to what extent the criteria of the Handbook, or criteria similar to these, can be used for formalizing a "global climate change mitigation criterion." It is well established that peatlands are the most space-effective carbon stores of the entire terrestrial biosphere and that peatland conservation (emission avoidance) and restoration (emission reduction) belong to the most cost-effective measures for long-term climate change mitigation (Parish et al. 2008, Joosten et al. 2012). The question, however, remains, how this is translated into onthe-ground criteria for identifying concrete peatlands that are of international (= global) relevance for climate regulation.

\section{The regulative framework}

Ramsar Resolution VII.11 "Strategic Framework and guidelines for the future development of the List of Wetlands of International Importance" states that the Ramsar Convention should achieve "a global network of sites.., which also contributes to ... maintaining the ecological and hydrological functions of wetlands that sustain human populations". Resolution IX.1 Annex B formulated the vision "To develop and maintain an international network of wetlands which are important ... for sustaining human life through the maintenance of their ecosystem components, processes and benefits/services" (where ecosystem services are "the benefits that people receive from ecosystems"). A global climate regulation (= climate change mitigation) criterion would clearly be in line with these decisions.

As examples of wetlands with "a major hydrological influence in the context of at least regional climate regulation or stability" are mentioned "certain areas of cloudforest or rainforest, wetlands or wetland complexes in semi-arid, arid or desert areas, tundra or peatland systems acting as sinks for carbon, etc." (art. 69 vi of the Handbook). 
The Ramsar "Guidance for identifying and designating peatlands ... as Wetlands of International Importance" (Resolution VIII.11) mentions among the significant features of peatlands (art. 139 of the Handbook):

- capacity to regulate local and regional climates,

- capacity to sequester carbon from the atmosphere and store it for long periods of time.

Furthermore, according to art. 144 in the Handbook, "special attention should be given to the designation of peatlands which have at least some of the following attributes:

- an intact hydrology,

- the presence of a peat-forming vegetation,

- the capacity to act as a carbon store,

- the presence of a carbon sequestration function".

Finally art. 146 in the Handbook states: "Large areas of peatland are normally of higher importance than small areas for their hydrological, carbon storage and palaeoarchive values and because they incorporate macro-landscapes: these should be afforded high priority for designation. Consideration should also be given to the capacity of the peatland system to influence regional climate."

\section{Climate parallels to existing criteria}

Whereas the presence of peat-forming vegetation, the capacity to act as a carbon store and the presence of carbon sequestration capacity are mentioned as important additional criteria for identifying Wetlands of International Importance, the question arises what the minimal requirements would be to designate a wetland with these criteria as the main argument. As all mires per definition sequester carbon and all peatlands per definition store carbon, such main argument should necessarily have minimal quantitative requirements: how much carbon should be sequestered or stored to call a peatland internationally important? 
With respect to conserving biological diversity the Ramsar Convention has formulated such quantitative minimum requirements and considers an area internationally important if it regularly supports (example on specific criteria 5 and 6 on waterbirds):

- 20,000 or more waterbirds

- $1 \%$ of the individuals in a population of one species or subspecies of waterbird

- $1 \%$ of the individuals in a population of one species or subspecies of wetland-dependent non-avian animal species. Recommended 1\% thresholds for the latter are provided under http://www.ramsar.org/ sites/default/files/documents/pdf/ris/key_ris_criterion9_2006.pdf

The 1\% criterion should guarantee that the most important areas are protected to let a population globally survive. The loss of areas with a smaller percentage of the population may lead to a loss of local values, but is not expected to jeopardize the population from an international and global perspective.

With respect to peat things are different. First, peat carbon is - from a climate perspective - not a localized, but a global asset: its value is independent of the location. For the climate is does not matter, where the peat is conserved or where the peat is growing.

Secondly, peatlands indeed grow and peat "reproduces" itself like species do, but the rate of peat accumulation in living mires is much slower than the rate of peat oxidation in degraded (drained) peatlands. The global peatlands are currently a net source of 5\% of all anthropogenic $\mathrm{CO}_{2}$ emissions to the atmosphere, in spite of more than $80 \%$ of the peatlands still being pristine (Joosten 2009). Worldwide peat disappears 10 times faster than it has been formed (Joosten \& Couwenberg 2008).

To maintain the global peatland carbon stock, some $90 \%$ (> 350 million ha, i.e. substantially more than the entire 2015 designation target of the Ramsar Convention of 250 million hectares) of the world's peatlands have to be conserved in a pristine state or be restored to peat accumulating conditions. To restore the global peatland climate cooling capacity, even $100 \%$ of the peatlands should be conserved or restored.

The effective conservation and restoration of Lille Vildmose would protect $0,001 \%$ of the global peatland carbon stock, the conservation of all 25,000,000 ha of Arctic polygon mires approximately 1\% (cf. Yang \& Couwenberg 2014), the conservation and restoration of all 13,150,000 ha of peatlands in Sumatra and Kalimantan 5\% (cf. Dommain et al. 2014) and the conservation of all 90,000,000 ha peatlands of the Western Sibe- 
rian lowlands (the largest concentration of peatlands in the World) approximately $10 \%$ (Kremenetsky et al. 2003).

Every designation of a peatland contributes to this global goal and obviously the larger the sequestration capacity and the larger the peatland carbon stock, the more the peatland contributes. A minimum threshold does not exist: the effective conservation of every peatland contributes to climate change mitigation, whereas the drainage of every additional peatland constitutes an additional burden for the climate.

The same accounts for emission reductions from peatland rewetting. The total greenhouse gas emissions from a concrete peatland are in essence a function of two variables: 1) the depth of drainage and 2) the area over which this drainage depth is maintained. Recent metaanalyses in the framework of IPCC indicate that the relation between total GHG emissions and mean annual water level is (apart from a small bump around- $50 \mathrm{~cm}$ that is attributable to $\mathrm{N}_{2} \mathrm{O}$ ) largely linear and continuous (fig. 4.1).

Fig. 4.1: GHG emissions and Global Warming Potentials from temperate peatlands as a function of mean annual water level. Left: data for individual gases, right: curves for all gases combined. Thin lines represent the $95 \%$ confidence intervals (Jurasinski et al. 2015)

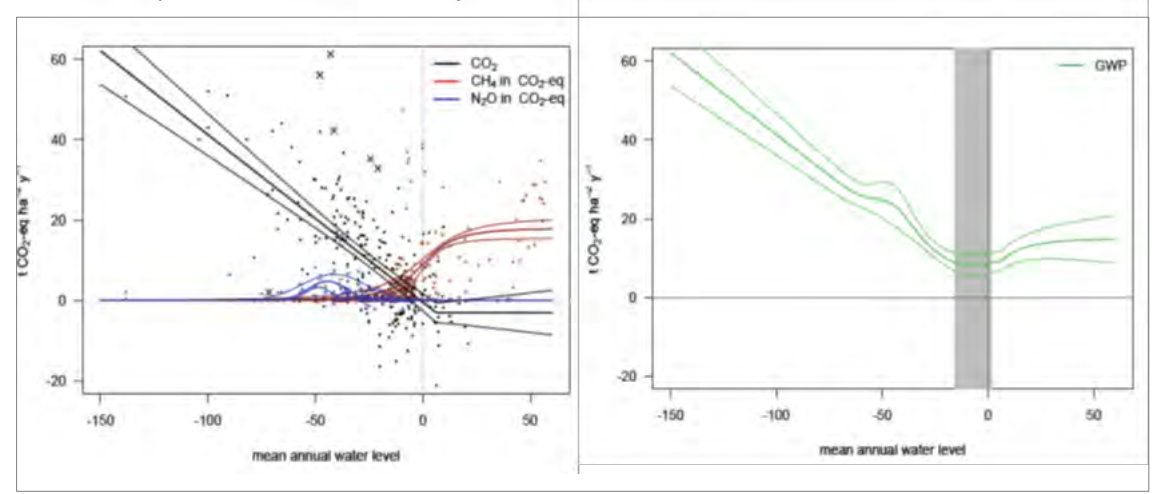

Jurasinski et al. 2015.

As also the relation between emissions and area is linear and continuous, a peatland rewetting strategy for climate regulation can be based on a simple and straightforward principle: the deeper the initial water levels and the larger the rewetted area, the better it is for the climate. 


\section{Conclusions and recommendations}

Drained peatlands constitute a disproportionally large climate burden. The $0.3 \%$ of the world's land area that consist of drained peatland is responsible for $5 \%$ of all anthropogenic $\mathrm{CO}_{2}$ emissions, tendency increasing.

There are many reasons for protecting mires and peatlands and for designating them as Ramsar Wetlands of International Importance. These reasons include the many ecosystem services that peatlands provide. Whereas most ecosystem services have a regional character, i.e. are mainly relevant for the communities in the surroundings of the peatland, the regulation of the climate by sequestering and storing carbon is a global asset, which is only relevant from a global perspective.

As gases in the atmosphere are within a few days distributed across the globe, greenhouse gas fluxes from peatlands have a direct effect on the global climate. They, however, do not specifically regulate the local or regional climate, except indirect via their influence on the global climate. It is both for the local and global climate inconsequential where on Earth emissions or emission reductions take place. A concrete peatland indeed contributes to global climate regulation, but the contribution of every individual peatland is only (very) small.

As a worldwide effective instrument for the conservation of wetlands, the Ramsar Convention could/should strengthen its efforts to conserve and restore the climate regulation function of the world's peatlands.

The global and comprehensive character of the peatland-climate relationship implies that the designation of peatlands as Wetlands of International Importance will make a useful but limited contribution to this aim, as designation will only concern a small selection of sites. Even the designation and effective conservation and restoration of the vast majority of the world's peatlands will not achieve a stabilization of the world's peat volume, as the peat losses from unprotected sites will - in case of maintenance and further expansion of drainage - completely overrule the carbon sequestration capacity of the protected sites. This is already the case in the current situation, where over $80 \%$ of the world's peatlands are still pristine. 
The designation of peatlands as Wetlands of International Importance using the climate regulation function as an additional argument will contribute to the further recognition of the important role of peatlands for the world's climate. Using this argument as the exclusive criterion will, in contrast, give the wrong impression that individual peatlands, even the largest ones, contribute decisively to climate change mitigation, therewith hampering the necessary comprehensive conservation of all peatlands as carbon sinks and stores.

The best climate change mitigation potential is in the most heavily degraded sites, especially deeply drained peatlands used as cropland, where rewetting can achieve the largest greenhouse gas emission reductions (tables 6.1 and 6.2). These areas are, however, often the least interesting from a biodiversity point of view, which will frustrate their designation as Wetland of International Importance. The best option for using an (additional) climate change mitigation argument (which also has been followed in case of Lille Vildmose) is to designate a complex with

- major parts that deserve designation on their own merit

- major degraded parts where restoration will

○ support and strengthen the conservation of adjacent good parts

- lead to a substantial emission reduction.

- nationally significant peat carbon stocks. 
Table 5.1: Emission reduction resulting from rewetting of peatlands in the boreal and temperate zone with various initial land use types as included in the 2013 IPCC Supplement: Wetlands (IPCC 2014). Emissions for drained and rewetted peatlands and emission reductions include $\mathrm{CO}_{2}, \mathrm{DOC}$, $\mathrm{CH}_{4}, \mathrm{CH}_{4}$ from ditches and $\mathrm{N}_{2} \mathrm{O}$ and are expressed in ${\mathrm{t} \mathrm{CO}_{2} \mathrm{e} \mathrm{ha}}^{-1} \mathrm{yr}^{-1}$. For calculation of the combined effect, a GWP of 23 is used for $\mathrm{CH}_{4}$ and 298 for $\mathrm{N}_{2} \mathrm{O}$

\begin{tabular}{|c|c|c|c|c|c|c|}
\hline \multirow[t]{2}{*}{ Initial land use } & \multicolumn{2}{|c|}{ Emissions drained } & \multicolumn{2}{|c|}{ Emissions rewetted } & \multicolumn{2}{|c|}{$\begin{array}{l}\text { Emissions reduction by } \\
\text { rewetting }\end{array}$} \\
\hline & boreal & temperate & boreal & temperate & Boreal & temperate \\
\hline $\begin{array}{l}\text { Forest Land, } \\
\text { nutrient poor }\end{array}$ & 1.7 & $12.2^{\mathrm{a}}$ & 0.3 & 2.9 & 1.4 & 9.3 \\
\hline $\begin{array}{l}\text { Forest Land, } \\
\text { nutrient rich }\end{array}$ & 5.5 & $12.2^{\mathrm{a}}$ & 2.5 & 9.3 & 3.0 & 2.8 \\
\hline Cropland & 36.8 & 37.5 & $2.5^{\mathrm{b}}$ & $9.3^{b}$ & 34.4 & 28.2 \\
\hline $\begin{array}{l}\text { Grassland, } \\
\text { nutrient poor }\end{array}$ & $27.2^{\mathrm{a}}$ & 24.0 & 0.3 & 2.9 & 26.9 & 21.1 \\
\hline $\begin{array}{l}\text { Grassland, } \\
\text { nutrient rich, } \\
\text { deep drained }\end{array}$ & $27.2^{\mathrm{a}}$ & 29.0 & 2.5 & 9.3 & 24.7 & 19.7 \\
\hline $\begin{array}{l}\text { Grassland, } \\
\text { nutrient rich, } \\
\text { shallow drained }\end{array}$ & $27.2^{\mathrm{a}}$ & 16.5 & 2.5 & 9.3 & 24.7 & 7.2 \\
\hline Peat extraction & 11.6 & 12.3 & $0.3^{c}$ & $2.9^{\mathrm{c}}$ & 11.3 & 9.4 \\
\hline
\end{tabular}

${ }^{a}$ note that no distinction is made between nutrient poor or rich and deep or shallow drainage.

${ }^{\mathrm{b}}$ rewetted croplands are assumed to be nutrient rich.

${ }^{c}$ rewetted peat extraction areas are assumed to be nutrient poor.

Table 5.2: Indicative total emission reduction resulting from rewetting peatlands with various initial land use (simplified version of table 6.1). Based on IPCC 2014 tier 1 default values for $\mathrm{CO}_{2}$ $\mathrm{CH}_{4}$, and $\mathrm{N}_{2} \mathrm{O}$ emissions, DOC export, and $\mathrm{CH}_{4}$ emissions from ditches, assuming for forest land an average nutrient level, for cropland and grassland a rich nutrient level, and for peat extraction sites a poor nutrient level. The higher values in the boreal zone are attributable to lower $\mathrm{CH}_{4}$ emissions after rewetting and to higher $\mathrm{N}_{2} \mathrm{O}$ emissions from drained grasslands

\begin{tabular}{|c|c|c|}
\hline \multirow[t]{2}{*}{ Initial drained land use } & \multicolumn{2}{|c|}{ Emission reduction after rewetting $\left(\left(\mathrm{t} \mathrm{CO}_{2}-\mathrm{e} \mathrm{ha}{ }^{-1} \mathrm{yr}^{-1}\right)\right)$} \\
\hline & Temperate zone & Boreal zone \\
\hline Forest Land & 6 & 2 \\
\hline Cropland: & 28 & 34 \\
\hline Grassland & 20 & 25 \\
\hline Peat extraction sites & 9 & 11 \\
\hline
\end{tabular}


The safeguarding of the climate regulation function of peatlands might benefit more from an all-encompassing wise use approach for all peatlands worldwide. The Ramsar Secretariat and the national Administrative Authorities should intensify its efforts in pursuing such comprehensive approach, which belongs to the foundations of the Ramsar Convention, especially in cooperation and in synergy with the many initiatives already being undertaken (see chapter 4 ).

Such wise use strategy could base on the following guidelines (Joosten et al. 2012):

- Secure undrained peatlands to prevent emissions.

- Rewet/restore drained/degraded peatlands to reduce emissions.

- If you need to use peatlands, use them wet (paludicultures).

- Adapt the management of peatlands that cannot be rewetted.

A crucial element of such strategy could be to use peatland Ramsar sites as centres for raising awareness on these issues, i.e. by illustrating the important role of peatlands for global climate regulation and for many other locally, nationally and internationally relevant ecosystem services and by providing on-the-ground examples of wise use and management. Such centres will be specifically effective for sites and in countries where natural, degraded and restored peatlands can be contrasted, where drivers and effects of non-wise use can be made easily apparent, where ample opportunity exists for communication, education and public awareness, and where a relevant audience is easily available (see also Ramsar Handbook 6, 4th edition: Wetland Communication Education Public Awareness). These attributes can support the arguments for designation of a peatland (complex) as a Wetland of International Importance. 


\section{References}

Alm, J., Schulman, L., Silvola, J., Walden, J., Nykänen, H. \& Martikainen, P.J. (1999). Carbon balance of a boreal bog during a year with an exceptionally dry summer. Ecology 80: 161-174. http://dx.doi.org/10.1890/0012-9658(1999)080 [0161:CBOABB]2.0.CO;2

Backshall, J., Manley, J. \& Rebane, M. (2001). Upland Management Handbook. English Nature, Peterborough.

Batjes, N.H. (1996). The total C and N in soils of the world. European Journal Soil Science 47: 151-163. http://dx.doi.org/10.1111/j.1365-2389.1996.tb01386.x

Biancalani, R. \& Avagyan, A. (eds.) (2014). Towards climate-responsible peatlands management. Mitigation of Climate Change in Agriculture Series 9, FAO, Rome, $100 \mathrm{p}$.

Botch, M. S. \& Masing, V. V. (1983). Mire Ecosystems in the U.S.S.R. In: Gore, A. J. P (ed.): Ecosystems of the world 4B. Mires: swamp, bog, fen and moor. Regional studies. Elsevier, Amsterdam, pp. 95-152.

Canaveira, P. (2013). Options and elements for an accounting framework for the land sector in the post-2020 climate regime. Terraprima Report to the Swiss Federal Office for the Environment, February 2014, 62 p.

Chistotin M. V., Sirin A. A. \& Dulov L. E. (2006). Seasonal dynamics of carbon dioxide and methane emission from peatland of Moscow Region drained for peat extraction and agricultural use. Agroshemistry N 6: 32-41. (in Russian).

Cleary, J., Roulet, N. T. \& Moore, T.R. (2005). Greenhouse gas emissions from Canadian peat extraction, 1990-2000: A Life-cycle Analysis. Ambio 34: 456-461.

Clymo, R.S. (1984). The limits to peat bog growth. Transactions of the Royal Society of London B, 303: 605-654. http://dx.doi.org/10.1098/rstb.1984.0002

Couwenberg, J. (2007). Biomass energy crops on peatlands: on emissions and perversions. IMCG Newsletter 2007/3: 12-14.

Crill, P., Hargreaves, K. \& Korhola, A. (2000). The Role of Peat in Finnish Greenhouse Gas Balances. Ministery of Trade and Industry Finland. Studies and Reports 10/2000, $71 \mathrm{p}$.

Dommain, R., Couwenberg, J. \& Joosten, H. (2011). Development and carbon sequestration of tropical peat domes in south-east Asia: links to postglacial sea-level changes and Holocene climate variability. Quaternary Science Reviews 30: 9991010. No reference. http://dx.doi.org/10.1016/j.quascirev.2011.01.018

Dommain, R., Couwenberg, J., Glaser, P.H., Joosten, H. \& Suryadiputra, I. N. N. (2014). Carbon storage and release in Indonesian peatlands since the last deglaciation. Quaternary Science Reviews 97: 1-32. http://dx.doi.org/10.1016/ j.quascirev.2014.05.002

Estrada, M., Lee, D., Murray, B., O’Sullivan, R., Penman, J. \& Streck, C. (2014). Land use in a future climate agreement. Prepared with support from cooperative agreement \# S-LMAQM-13-CA-1128 with U.S. Department of State. http://merid.org/land-usein-ADP /

Eswaran, H., van den Berg, E. \& Reich, P. (1993). Organic carbon in soils of the world. Soil Sci. Soc. Am. J. 57: 192-194. http://dx.doi.org/10.2136/ sssaj1993.03615995005700010034x 
Eurola, S., Hicks, S. \& Kaakinen, E. (1984). Key to Finnish mire types. In: Moore, P.D. (ed.): European miresby. Academic Press, London, pp. 11-117. http://dx.doi.org/10.1016/B978-0-12-505580-2.50006-4

ETC/BD (2008). Article 17 reporting selected highlights http://eea.eionet.europa.eu/Public/irc/eionet-circle/habitats-art17report/ library?l=/papers_technical/selected_highlightspdf/_EN_1.0_\&a=d

Evans, C., Norris, D. \& Rowe, E. (2005). A regional water and soil quality survey of the North York Moors. CEH Report C02661 for DEFRA.

Francez, A.-J. \& Vasander, H. (1995). Peat accumulation and peat decomposition after human disturbance in French and Finnish mires. Acta Oecologica 16: 599-608.

Franzén, L.G., Deliang, C.\& Klinger, L.F. (1996). Principles for a climate regulation mechanism during the Late Phanerozoic Era, based on carbon fixation in peatforming wetlands. Ambio 25: 435-442.

Frolking, S. \& Roulet, N.T. (2007). Holocene radiative forcing impact of northern peatland carbon accumulation and methane emissions. Global Change Biology 13: 1079-1088. http://dx.doi.org/10.1111/j.1365-2486.2007.01339.x

Frolking, S., Roulet, N. \& Fuglestvedt, J. (2006). How northern peatlands influence the Earth' s radiative budget: Sustained methane emission versus sustained carbon sequestration. J. Geophys. Res.111 G01008. http://dx.doi.org/10.1029/2005JG000091

Gao, Y. \& Couwenberg, J. (2014). Carbon accumulation in a permafrost polygon peatland: steady long term rates in spite of shifts between dry and wet conditions. Global Change Biology, submitted.

Heathwaite, A.L. \& Göttlich, K.-H. (eds.) (1993). Mires - Process, exploitation and conservation. Wiley, Chichester.

Holden, J., Chapman, P., Evans, M., Hubacek, K., Kay, P. \& Warburton, J. (2006). Vulnerability of organic soils in England and Wales. Final technical report to DEFRA, Project SP0532, $137 \mathrm{p}$.

Houghton, R.A. (2007). Balancing the global carbon budget. Annual Review of Earth and Planetary Sciences 35: 313-347. http://dx.doi.org/10.1146/ annurev.earth.35.031306.140057

IPCC (2013). Climate Change 2013: The Physical Science Basis. Contribution of Working Group I to the Fifth Assessment Report of the Intergovernmental Panel on Climate Change [Stocker, T.F., Qin, D., Plattner, G.-K., Tignor, M., Allen, S.K., Boschung, J., Nauels, A., Xia, Y., Bex, V. \& Midgley, P.M. (eds.)]. Cambridge University Press, Cambridge, $1535 \mathrm{pp}$.

IPCC (2014a). 2013 Supplement to the 2006 IPCC Guidelines for National Greenhouse Gas Inventories: Wetlands. Ed. by Hiraishi, T., Krug, T., Tanabe, K., Srivastava, N., Baasansuren, J., Fukuda, M. \& Troxler, T.G. (eds). IPCC, Switzerland, 354 p.

IPCC (2014b). 2013 Revised Supplementary Methods and Good Practice Guidance arising from the Kyoto Protocol. Ed. by Hiraishi, T., Krug, T., Tanabe, K., Srivastava, N., Baasansuren, J., Fukuda, M. \& Troxler, T.G. IPCC, Switzerland, 268 p.

Iversen, P., Lee, D. \& Rocha, M. (2014). Understanding Land Use in the UNFCCC. 66 p. Jeschke, L., Knapp, H. D. \& Succow, M. (2001). Moorregionen Europas. In: Succow, M. \& Joosten, H. (eds.): Landschaftsökologische Moorkunde. Schweitzerbart, Stuttgartpp. 256-264.

Jobbágy, E.G. \& Jackson, R.B. (2000). The vertical distribution of soil organic carbon and its relation to climate and vegetation. Ecological Applications 10: 423-436. http://dx.doi.org/10.1890/1051-0761(2000)010[0423:TVDOSO]2.0.CO;2 
Joosten, H. (2008). What are peatlands? In: Parish, F., Sirin, A., Charman, D., Joosten, H., Minaeva, T. \& Silvius, M. (eds) (2008). Assessment on peatlands, biodiversity and climate change. Global Environment Centre, Kuala Lumpur and Wetlands International Wageningen, pp. 8-19.

Joosten, H. (2009). The Global Peatland $\mathrm{CO}_{2}$ Picture. Peatland status and drainage associated emissions in all countries of the World. Wetlands International, Ede, 10 p. + tables.

Joosten, H. (2011). Sensitising global conventions for climate change mitigation by peatlands. In: Tanneberger, F. \& Wichtmann, W. (eds.) (2011). Carbon credits from peatland rewetting. Climate - biodiversity - land use. Science, policy, implementation and recommendations of a pilot project in Belarus. Schweizerbart, Stuttgart, p. 90-94.

Joosten, H. \& Clarke, D. (2002). Wise use of mires and peatlands - Background and principles including a framework for decision-making. International Mire Conservation Group / International Peat Society, Jyvaskyla, 304 p.

Joosten, H. \& Couwenberg, J. (2008). Peatlands and carbon. In: Parish, F., Sirin, A., Charman, D., Joosten, H., Minaeva, T. \& Silvius, M. (eds) (2008). Assessment on peat lands, biodiversity and climate change. Global Environment Centre, Kuala Lumpur and Wetlands International Wageningen, pp. 99-117.

Joosten, H. (2008). What are peatlands? In: Parish, F., Sirin, A., Charman, D., Joosten, H., Minaeva, T. \& Silvius, M. (eds) (2008). Assessment on peatlands, biodiversity and climate change. Global Environment Centre, Kuala Lumpur and Wetlands International Wageningen, pp. 8-19.

Joosten, H., Tapio-Biström, M.-L. \& Tol, S. (eds.) (2012). Peatlands - guidance for climate change mitigation by conservation, rehabilitation and sustainable use. Second edition. Mitigation of Climate Change in Agriculture Series 5. FAO, Rome, L + $100 \mathrm{p}$.

Joosten, H., Brust, K., Couwenberg, J., Gerner, A., Holsten, B., Permien, T., Schäfer, A.,Tanneberger, F., Trepel, M. \& Wahren, A. (2013). MoorFutures® Integration von weiteren Ökosystem-dienstleistungen einschließlich Biodiversität in Kohlenstoffzertifikate - Standard, Methodologie und Übertragbarkeit in andere Regionen. BfN Skripten 350, Bundesamt für Naturschutz, Bonn, 130 p.

Jungkunst, H.F., Krüger, J.-P., Heitkamp, F., Erasmi, F., Glatzel, S. \& Fiedler, S. 2015). Accounting more precisely for peat and other soil carbon resources. In: Lal, R., Lorenz, K., Hüttl, R.F., Schneider, B.U. \& von Braun, J. (eds.): Recarbonization of the biosphere. Springer, Amsterdam, pp. 127-157.

Jurasinski, G., Günther, A., Huth, V., Couwenberg, J. \& Glatzel, S. (2015). Greenhouse gas emissions. In: Wichtmann, W., Schröder, C. \& Joosten, H. (eds.): Paludiculture Productive use of wet peatlands. Schweizerbart, Stuttgart.

Kirschke, S., Bousquet, P., Ciais, P., Saunois, M., Canadell, J. G., Dlugokencky, E. J., Bergamaschi, P., Bergmann, D., Blake, D. R., Bruhwiler, L., Cameron-Smith, P., Castaldi, S., Chevallier, F., Feng, L., Fraser, A., Fraser, P. J., Heimann, M., Hodson, E. L., Houweling, S., Josse, B., Krummel, P. B., Lamarque, J. -F., Langenfelds, R. L., Le Quéré, C., Naik, V., O’Doherty, S., Palmer, P. I., Pison, I., Plummer, D., Poulter, B., Prinn, R. G., Rigby, M., Ringeval, B., Santini, M., Schmidt, M., Shindell, D. T., Simpson, I. J., Spahni, R., Steele, L. P., Strode, S. A., Sudo, K., Szopa, S., van der Werf, G. R., Voulgarakis, A., van Weele, M., Weiss, R. F., Williams, J. E. \& Zeng, G. (2013). Three decades of global methane sources and sinks. Nature Geoscience 6: 813-823.

http://dx.doi.org/10.1038/ngeo1955 
Kremenetski, K.V., Velichko, A.A., Borisova, O.K., MacDonald, G.M., Smith, L.C., Frey, K.E. \& Orlova, L.A. (2003). Peatlands of the Western Siberian lowlands: current knowledge on zonation, carbon content and Late Quaternary history. Quaternary Science Reviews 22: 703-723. http://dx.doi.org/10.1016/S0277-3791(02)00196-8

La Vina, A.G.M., Labre, L., Ang, L. \& de Leon, A. (2012). The Road to Doha: The future of REDD-Plus, agriculture, and land-use change in the UNFCCC. Working paper, Foundation for International Environmental Law and Development, $12 \mathrm{p}$.

Lal, R. (1999). Global carbon pools and fluxes and the impact of agricultural intensification and judicious land use. In: Prevention of land degradation, enhancement of $C$ sequestration and conservation of biodiversity though land use change and sustainable land management with a focus on Latin America and the Caribbean. FAO, Rome, pp. 45-52.

Lal, R. (2003). Soil erosion and the global carbon budget. Environment International 29: 437-450. http://dx.doi.org/10.1016/S0160-4120(02)00192-7

Lal, R. (2004). Soil carbon sequestration impacts on global climate change and food security. Science 304: 1623-1627. http://dx.doi.org/10.1126/science.1097396

Le Quéré, C., Andres, R. J., Boden, T., Conway, T., Houghton, R. A., House, J. I., Marland, G., Peters, G. P., van der Werf, G. R., Ahlström, A., Andrew, R. M., Bopp, L., Canadell, J. G., Ciais, P., Doney, S. C., Friedlingstein, P., Huntingford, C., Jain, A. K., Jourdain, C., Kato, E., Keeling, R., Klein Goldewijk, K., Levis, S., Levy, P., Lomas, M., Poulter, B., Raupach, M., Schwinger, J., Sitch, S., Stocker, B. D., Viovy, N., Zaehle S. \& Zeng, N. (2013). The Global Carbon Budget 1959-2011. Earth System Science Data, doi:10.5194/essdd-5-165-2013, http://www.earth-syst-sci-data-discuss.net/ 5/165/2013/

Lohila, A., Minkkinen, K., Laine, J., Savolainen, I., Tuovinen, J. P., Korhonen, L., Laurila, T., Tietavainen, H. \& Laaksonen, A. (2010). Forestation of boreal peatlands: Impacts of changing albedo and greenhouse gas fluxes on radiative forcing. Journal of Geophysical Research 115, G04011, http://dx.doi.org/10.1029/2010JG001327

MacDonald, G.M., Beilman, D. W., Kremenetski, K. V., Sheng, Y., Smith, L.C. \& Velichko, A. A. (2006). Rapid early development of circumarctic peatlands and atmospheric CH4 and $\mathrm{CO}_{2}$ variations. Science 314: 285-288. http://dx.doi.org/10.1126/ science. 1131722

Martikainen, P.J., Nykänen, H., Alm, J. \& Silvola, J. (1995). Change in fluxes of carbon dioxide, methane and nitrous oxide due to forest drainage of mire sites of different trophy. Plant and Soil 168-169: 571-577. http://dx.doi.org/10.1007/BF00029370

Mäkiranta, P., Hytönen, J., Aro, L., Maljanen, M., Pihlatie, M., Potila, H., Shurpali, N.J., Laine, J., Lohila, A., Martikainen, P.J. \& Minkkinen, K. (2007). Soil greenhouse gas emissions from afforested organic soil croplands and peat extraction peatlands. Boreal Environment Research 12: 159-175.

Minkkinen, K. \& Laine, J. (2006). Vegetation heterogeneity and ditches create spatial variability in methane fluxes from peatlands drained for forestry. Plant and Soil 285: 289-304. http://dx.doi.org/10.1007/s11104-006-9016-4

Minaeva, T. \& Joosten, H. (2009). Ramsar CoP 10 and peatlands. IMCG Newsletter 2009-1: 9-13.

Ojanen, P., Minkkinen, K., Alm, J. \& Penttilä, T. (2010). Soil-atmosphere $\mathrm{CO}_{2}, \mathrm{CH}_{4}$ and $\mathrm{N}_{2} \mathrm{O}$ fluxes in boreal forestry-drained peatlands. Forest Ecology and Management 260: 411-421. http://dx.doi.org/10.1016/j.foreco.2010.04.036

Prager, A., Barthelmes, A. \& Joosten, H. (2006). A touch of tropics in temperate mires: on Alder carrs and carbon cycles. Peatlands International 2006/2: 26-31. 
Parish, F. Sirin, A., Charman, D., Joosten, H., Minayeva, T. and Silvius, M. (eds.) (2007). Assessment on Peatlands, Biodiversity and Climate Change: Executive Summary. Global Environment Centre, Kuala Lumpur and Wetlands International, Wageningen, $18 \mathrm{p}$.

Parish, F., Sirin, A., Charman, D., Joosten, H., Minaeva, T. \& Silvius, M. (eds) (2008). Assessment on peatlands, biodiversity and climate change. Global Environment Centre, Kuala Lumpur and Wetlands International Wageningen, $179 \mathrm{p}$.

Parker, C., Merger, E., Streck, C., Conway, D., Tennigkeit, T. \& Wilkes, A. (2014). The land-use sector within the post-2020 climate regime. TemaNord 2014:520, Nordic Council of Ministers, 106 p. http://dx.doi.org/10.6027/TN2014-520

Roulet, N.T., LaFleur, P.M., Richards, P.J., Moore, T.R., Humphreys, E.R. \& Bubier, J. (2007). Contemporary carbon balance and late Holocene carbon accumulation in a northern peatland. Global Change Biology 13: 397-411. http://dx.doi.org/10.1111/ j.1365-2486.2006.01292.x

Sirin, A. \& Laine, J. (2008). Peatlands and greenhouse gases. In: Parish, F., Sirin, A., Charman, D., Joosten, H., Minaeva, T. \& Silvius, M. (eds) (2008). Assessment on peatlands, biodiversity and climate change. Global Environment Centre, Kuala Lumpur and Wetlands International Wageningen, pp. 118-138.

Smith, P. (2014). Do grasslands act as a perpetual sink for carbon? Global Change Biology 20: 2708-2711. http://dx.doi.org/10.1111/gcb.12561

Sundh, I., Nilsson, M., Mikela, C., Granberg, G. \& Svensson, B.H. (2000). Fluxes of methane and carbon dioxide on peat-mining areas in Sweden. Ambio 29: 499-503.

Tarnocai, C., Canadell, J.G., Schuur, E.A.G., Kuhry, P., Mazhitova, G. \& Zimov, S. (2009). Soil organic carbon pools in the northern circumpolar permafrost region. Global Biogeochem. Cycles 23, GB2023, http://dx.doi.org/10.1029/2008GB003327

Trepel, M. (2004). The European Water Framework Directive - A chance for mire conservation and peatland restoration? IMCG Newsletter 2004/5: 3-4. No references.

Turunen, J., Tomppo, E., Tolonen, K. \& Reinikainen, A. (2002). Estimating carbon accumulation rates of undrained mires in Finland - Application to boreal and subarctic regions. The Holocene 12: 69-80. http://dx.doi.org/10.1191/ 0959683602hl522rp

Von Arnold, K., Nilsson, M., Hånell, B., Weslien, P. \& Klemedtsson, L. (2005a). Fluxes of $\mathrm{CO}_{2}, \mathrm{CH}_{4}$ and $\mathrm{N}_{2} \mathrm{O}$ from drained organic soils in deciduous forests. Soil Biology and Biochemistry 37: 1059-1071. http://dx.doi.org/10.1016/j.soilbio.2004.11.004

Von Arnold, K., Weslien, P., Nilsson, M., Svensson, B.H. \& Klemedtsson, L. (2005). Fluxes of $\mathrm{CO}_{2}, \mathrm{CH}_{4}$ and $\mathrm{N}_{2} \mathrm{O}$ from drained coniferous forests on organic soils. Forest Ecology and Management 210: 239-254. http://dx.doi.org/10.1016/j.foreco.2005.02.031

Von Unger, M., Emmer, I., Couwenberg, J. \& Joosten, H. (2014). Carbon market approaches for peatlands and forests. Status Report I. German Emissions Trading Authority (DEHSt) at the Federal Environment Agency, Berlin, 36 p.

Waddington, J.M., Warner, K.D. \& Kennedy, G.W. (2002). Cutover peatlands: a persistent source of atmospheric $\mathrm{CO}_{2}$. Global Biogeochem. Cycles 16: 1-7. http://dx.doi.org/10.1029/2001GB001398

Yu, Z., Campbell, I.D., Campbell, C., Vitt, D. H., Bond, G. C. \& Apps, M. J. (2003). Carbon sequestration in western Canadian peat highly sensitive to Holocene wet-dry climate cycles at millennial timescales. The Holocene 13: 801-808. http://dx.doi.org/10.1191/0959683603hl667ft 



\section{Resumé}

Ramsarkonventionen er en global rammeaftale for national handling og internationalt samarbejde omkring beskyttelse og bæredygtig udnyttelse af vådområder og deres ressourcer. Anbefalinger besluttet til Ramsarkonventionens partskonferencer har igennem en årrække haft fokus på moser og tørveområders betydning med henblik på at afbøde klimaændringer. Anbefalingerne har bl.a. opfordret de 168 partnerlande til at fremme genopretning og forbedre forvaltningen af de moser og tørveområder, som udgør signifikante kulstoflagre og hotspots for biodiversitet, og hvor en høj vandstand vil kunne reducere udledningen af drivhusgasser.

Det nordisk-baltiske vådområde Initiativ er et regionalt Ramsar samarbejde med deltagelse fra Danmark, Grønland, Færøerne, Estland, Finland, Island, Letland, Litauen, Norge, Sverige og Oblasts fra Nordvest Rusland (NorBalWet). Et af samarbejdsområderne i NorBalWet er vidensudveksling om sikring og genopretning af moser.

I 2013 udpegede Danmark Lille Vildmose, den største tilbageværende højmose i Danmark, som det første Ramsar område af international betydning efter kriteriet omkring truede økologiske samfund og klimaregulering. Samme år anvendte Sverige samme kriterium for klimaregulering for otte nye svenske Ramsar-områder. Efterfølgende iværksatte NorBalWet nærværende projekt, der har til hensigt at vurdere de nordisk-baltiske mose- og tørveområders betydning som kulstoflagre og potentiale for klimaregulering.

Moser er defineret som områder hvor vandstanden er stabilt høj, og som følge heraf er nedbrydningen af døde plantedele nedsat og der akkumuleres kulstofrige tørvelag. Moser indeholder derfor mere kulstof end andre terrestriske økosystemer, f.eks. op til 7 gange mere i den boreale zone. Når moser drænes iltes tørven, hvilket resulterer i emission af betydelige mængder drivhusgasser.

NorBalWet landene rummer ifølge nærværende studie ca. 250,000 km² tørvearealer (Færøerne og Rusland undtaget) dvs. næsten $6 \%$ af de globale tørveområder. Disse tørveområder/moser er vigtige i forbindelse med bevarelse af biodiversitet og andre økosystemydelser herunder kulstof oplagring. 
Næsten halvdelen af moserne, i de Nordiske og Baltiske lande, er drænede. Drænede moser er ansvarlige for en emission på mere end $75 \mathrm{Mt}$ $\mathrm{CO}_{2}$ om året, hvilket er en betydelig del af landenes samlede $\mathrm{CO}_{2}$ budget. Emissionen af $\mathrm{CO}_{2}$ fra tørveområder udgør således $33 \%$ af den samlede $\mathrm{CO}_{2}$ emission fra alle andre kilder tilsammen (med undtagelse af arealanvendelse, ændring i arealanvendelse og skove forkortet LULUCF), hvilket illustrerer tørveområders betydning som nationale bidrag til regulering af drivhusgasser. Tallene dækker dog over store nationale forskelle.

For Island og Letland er emissionen fra tørveområder dobbelt så stor som totalen af andre emissioner dog er emissionen på Island muligvis overestimeret. For Estland, Litauen og Finland er emissionen fra tørveområder ca. 50 \% af totalen. En stor del af tørveområderne er stærkt påvirket af menneskelig aktivitet, især dræning, tilplantning og tørveindvinding. Kun Danmark og Grønland har emission fra tørveområder på under $10 \%$ af den samlede emission fra andre kilder. For Danmarks vedkommende fordi mange tørveområder er så nedbrudte, at der ikke længere er tørv tilstede, og emissionen er derfor lille. Grønland har aldrig været intensivt opdyrket, og der er ringe viden om udbredelsen af tørveområder. Til gengæld vil klimaændringer sandsynligvis medføre at flere tørveområder vil blive opdyrket eller anvendt til græsning. Arealet med fåregræsning er fordoblet siden 1990, og især tørvejorder kan være frugtbare.

Genopretning af områderne, så tørvelagene igen er vandmættede (genopretning af vandstanden), giver en betydelig reduktion i emission af drivhusgasser, illustreret herunder af de nye retningsliner fra klimapanelet under klimakonventioen (Intergovernmental Panel on Climate Change, IPCC):

$\begin{array}{lrr}\text { Drænet udgangspunkt } & \text { Nedbragt emission efter vådgøring }\left(\left(\mathrm{t} \mathrm{CO}_{2}-\mathrm{e} \mathrm{ha}{ }^{-1} \mathbf{~ v r}^{-1}\right)\right) \\ & \text { Tempererede zone } & \text { Boreale zone } \\ \text { Skov } & 6 & 2 \\ \text { Agerjord } & 28 & 34 \\ \text { Græs } & 20 & 25 \\ \text { Tørveindvinding } & 9 & 11\end{array}$

Tabellen viser potentialet for nedsættelse af emissionen ved hævning af vandstand for fire forskellige arealanvendelser af drænet $t \varnothing r v$. Der er forskel på den potentielle effekt for forskellige klimazoner her eksemplificeret ved den tempererede og boreale zone.

Genopretning af tørveområder (herunder genetablering af høj vandstand) følger en vifte af initiativer og aftaler som de Nordiske og Baltiske 
lande er involveret i. Udover Ramsarkonventionen, gælder det Klimakonvention (UNFCCC) herunder Kyotoprotokollen, Biodiversitetskonventionen (CBD) og Aichi målene, UNESCOs Verdensarv, strategien omkring Heritage Management af Vådområder under det Europæiske Agentur om Arkæologi, klimainitiativer under FN's Fødevarer og Landbrugsorganisation (FAO), EU's Habitatdirektiv og Vandrammedirektiv samt Helsinkikonventionen. Ramsarkonventionens bæredygtighedsprincip "wise use" udgør en bro mellem disse aftaler.

Som et globalt instrument for bevarelse af vådområder, kan Ramsarkonventionen skærpe indsatsen for at bevare og genoprette den klimaregulerende funktion for verdens moser og tørveområder. Da atmosfæriske gasser indenfor få dage fordeles rundt om jorden, er det for klimaet uden forskel, hvor på jorden emissioner eller reduktion i emissioner finder sted.

Udpegning af tørveområder som Ramsarområder giver i sig selv et begrænset bidrag til afbødning af klimaeffekten, da tabet af $\mathrm{CO}_{2}$ fra tørv fra drænede, udnyttede områder allerede i dag langt overgår den oplagring, der sker her og nu i intakte områder. Dette er tilfældet, selv om mere end $80 \%$ af verdens moser/tørveområder er uberørte og derfor ikke drænet.

Ramsar udpegning af moseområder med klimafunktionen som et tillægskriterium vil bidrage til vidensopbygning og information omkring den meget store betydning verdens moser/tørveområder har for det globale klima. Kriteriet kan ikke anvendes isoleret, fordi det kan give det indtryk, at enkeltområder (selv de største) bidrager afgørende til at afbøde klimaeffekten.

Beskyttelse af mosers klimafunktion vil have størst effekt, hvis det involverer alle verdens moser.

Opbygning af formidlingsfaciliteter i tilknytning til Ramsarområder med moser vil medvirke til at øge kendskabet til mosernes rolle ift. klimaregulering. Specielt områder, hvor kontrasten mellem naturlige, nedbrudte og genoprettede områder kan formidles, så besøgende kan se forskellene, og koble årsag og virkning, er værdifulde. 



\section{Annex: Country profiles}

The following country profiles give an overview of the extent, distribution and status of peatlands in the various NorBalWet countries. Our aim has been to give a spatial explicit overview, i.e. to indicate where how much peatlands in drained and undrained condition occur.

We used for our analysis a wide variety of data that have been made available by the respective countries and that are available on the internet and in our own databases.

The analysis shows that the availability and the quality of the data differ considerably among countries and that also within countries the data are not always fully consistent. This applies to the total area of peatlands, their condition and the anthropogenic greenhouse gas emissions reported from these peatlands.

Opportunities for improvement of the available data exist in

- A wall-to-wall inventory and reporting of peatlands/organic soils. The databases used sometimes exclude considerable areas of peatlands, as they have been conceived for other purposes. As a result sometimes peatlands seem to be neglected, e.g. those that have been abandoned after agriculture or peat extraction.

- A consistent use of terms and concepts. Currently datasets use a variety of concepts, including vegetation types, organic soils, peatlands or local terms, which are not fully compatible. Furthermore we noted in some cases inconsistent use of the same terms, e.g. different minimum depth of organic soil for different types of land use. Also concepts are used, that are incompatible with the definitions of organic soil of IPCC and UNFCCC.

- A recognition of the distant impact of drainage infrastructure. In fact peatlands not only have to be considered drained when drainage infrastructure (ditches, pipes, etc.) is present on the respective plots, but also the effect of adjacent drainage on "undrained" areas has to be taken into account. 
- The correct assignment to climate zones. With respect to emissions, we noted that some countries position themselves in their UNFCCC reporting in another climate/vegetation zone than they actually belong to and use as a result not the correct emission factors.

- The use of the most recent emission factors. Recently the IPCC emission factors for organic soils have been substantially updated. Although the new figures have been officially accepted by the NorBalWet countries as members of the IPCC in October 2013, the countries use for their April 2014 reporting still "outdated" emission factors, which generally lead to too low emissions.

In the following country profiles we discuss our findings for the NorNalWet countries and try to estimate the current $\mathrm{CO}_{2}$ emissions from drained peatland. Whereas we recognize that our analysis is incomplete, we hope that the presented considerations are taken as an invitation to improve the inventory and emission estimates of peatlands. 


\subsection{Estonia}

\subsubsection{Characterization of the country}

Figure 1: NorBalWet countries covered in this report (grey); Estonia (dark grey)

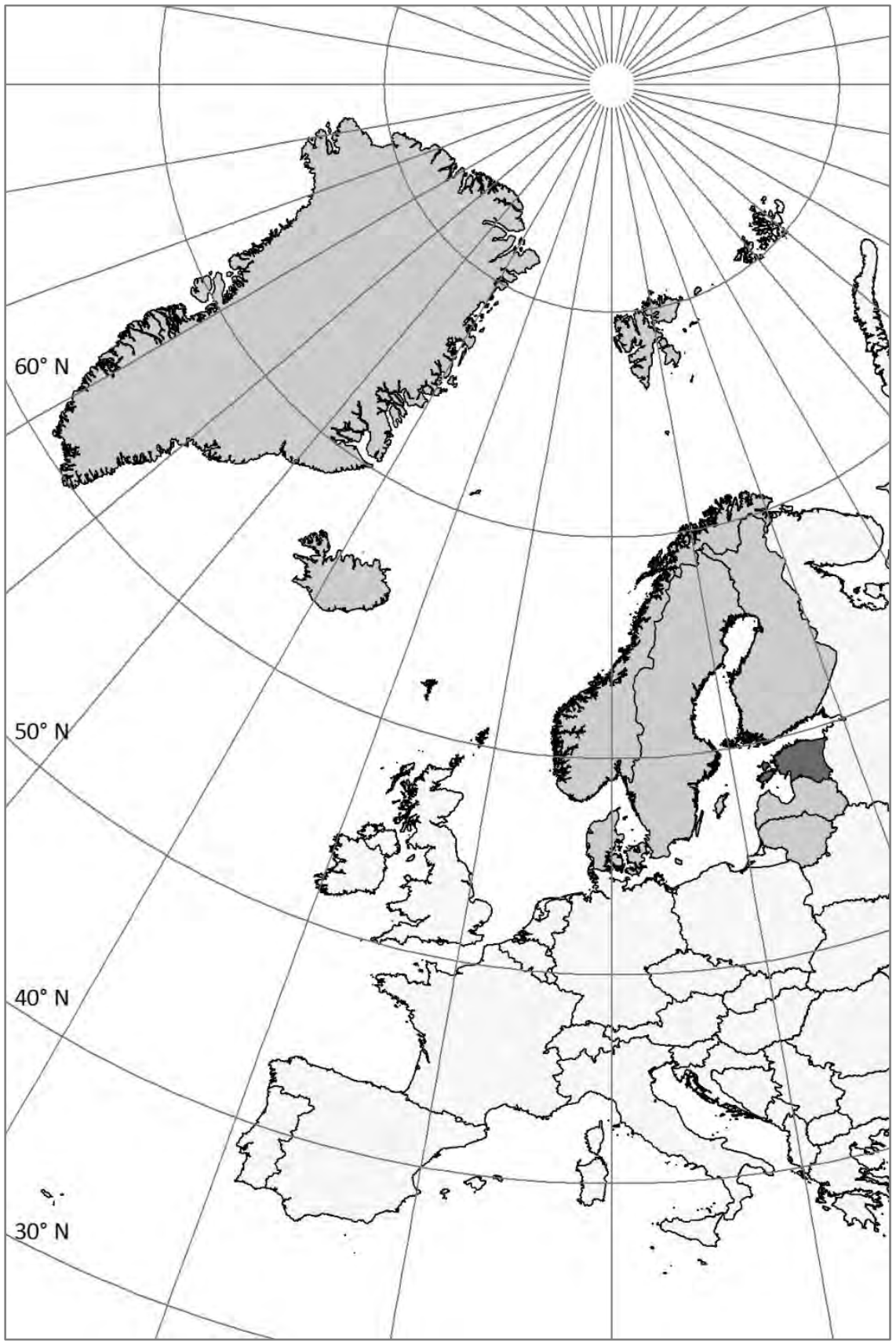


The Republic of Estonia is situated on the East coast of the Baltic Sea between $57^{\circ}$ and $59^{\circ} \mathrm{N}$ and $21^{\circ}$ and $28^{\circ} \mathrm{E}$ (Figure 1). Its territory covers about $45,227 \mathrm{~km}^{2}$. Geologically, Estonia is situated in the north-western part of the East-European platform and lies mainly within the boundaries of the southern slope of the Fennoscandian shield (Raukas 1997). Deglaciation processes and the development of the Baltic Sea are largely responsible for the current geomorphologic situation. The country is plain with only small differences in height. The Quaternary cover is rather thin and varies from approximately $5 \mathrm{~m}$ in northern Estonia to $207 \mathrm{~m}$ in southern Estonia (Raukas \& Kajak 1997). Mean annual precipitation varies from $509 \mathrm{~mm}$ on the western Islands to $746 \mathrm{~mm}$ in south-eastern Estonia. Mean February temperature varies from $-3.5^{\circ} \mathrm{C}$ to $-7.6^{\circ} \mathrm{C}$, mean July temperature from $16.3^{\circ} \mathrm{C}$ to $17.1^{\circ} \mathrm{C}$ on the western Islands and north-eastern Estonia, respectively (Ilomets 2015).

\subsubsection{Peatland diversity}

Paal \& Leibak (2011) distinguished seven main mire ${ }^{1}$ types: species-rich fens, spring fens, floodplain (limnogenous) fens, poor fens, transitional (mixotrophic) fens/bogs, heath moors and ombrotrophic bogs. Speciesrich fens are mainly found on calcareous bedrock on Saaremaa Island and in the western coastal part of the mainland. This mire type often forms shallow peat deposits (up to $1 \mathrm{~m}$ ) and the number of species may exceed 130 species. Spring fens are rather sparsely distributed over Estonia, mainly on the marginal slopes of Pandivere and Sakala Uplands and on Saaremaa Island. They are usually supplied by calcium-rich water. Floodplain fens are most widely represented in the lowermost part of the river valleys in western and south-western Estonia and in eastern and south-eastern Estonia. Poor fens are more common in eastern Estonia and dominated by sedges. Transitional fens/bogs occur in western, central and north-eastern Estonia, around lakes, and are forming belts around large ombrotrophic bogs. Heath moors lay in depressions between sandy dunes on the western coast and on Hiiumaa Island, and between old dunes far from the recent coastline. The larger ombrotrophic bogs are located in the western, central and north-eastern parts of the Estonian mainland.

\footnotetext{
${ }^{1}$ Mire is a peatland with a peat layer of at least $30 \mathrm{~cm}$ depth which is continuou sly forming and accumulating; in mire the average height of tree layers does not exceed $4 \mathrm{~m}$ and tree layer density is less than 0.3 (projective cover less than 30\%); (Paal \& Leibak 2011).
} 


\subsubsection{Peatland degradation}

Exploitation of mires for peat mining and agriculture started in the 17th century (Valk 1988). In the period 1918-1940, more than $350 \times 10^{3}$ ha of organic and wet mineral soils was drained, predominantly for agriculture. Since ditches were only $50 \mathrm{~cm}$ deep, the drainage impact was probably modest (Ilomets 2015). Until the end of the 1980s an estimated area of $250-300 \times 10^{3}$ ha of mires has been drained for agriculture (Ilomets 2015), including about $120 \times 10^{3}$ ha fens with a peat layer thicker than $40 \mathrm{~cm}$ (Valk 1988).

Drainage of mires for improved forest production and afforestation started in the beginning of the 19th century and continued more systematically after 1830/1840 on a rather small scale. Between 1918 and 1940 some $15 \times 10^{3}$ ha of mires were drained for forestry (Ilomets 2015). After 1950, when powerful machinery became available, the rate of mire drainage for forestry significantly increased. In total $460 \times 10^{3}$ ha of peatlands and other wetlands have been drained for forestry in Estonia (Paavilainen \& Päivänen 1995).

Peat extraction for fuel started in the 17th century and gradually increased, especially since the beginning of the 20th century (Ilomets et al. 1995). Peat extraction is still an important economic activity. Approximately $30 \times 10^{3}$ ha of mires have been destroyed directly by peat extraction, whereas another $30 \times 10^{3}$ ha have been affected indirectly by drainage. Some $5.0 \times 10^{3}$ ha of valuable mires have furthermore been destroyed and $1.5 \times 10^{3}$ ha indirectly affected by open-cast oil shale mining in north-eastern Estonia. The latter process still continues on a small scale (Ilomets 2015).

In total, some $3 \times 10^{3}$ ha of mires have been affected by urban development, e.g. for garbage dumping areas or holiday camps, predominantly near Tallinn, the capital of Estonia (Ilomets 2015).

All together $610-650 \times 10^{3}$ ha of Estonian mires ( $\sim 65 \%$ of the total area) have been strongly affected or destroyed by human activities (Ilomets 2015). 


\begin{tabular}{|c|c|c|c|}
\hline \multirow[t]{2}{*}{ Habitat site type } & \multicolumn{3}{|c|}{ Area $\left(10^{3} \mathrm{ha}\right)$} \\
\hline & Laasimer (1965) & llomets et al. (2010) & Paal \& Leibak (2011) \\
\hline Poor fens & 152.5 & 17.0 & 19.0 \\
\hline Rich fens & 74.9 & 5.0 & 20.0 \\
\hline Minerotrophic quagmires & 1.3 & 0.3 & 1.8 \\
\hline Floodplain fens & 83.0 & 1.0 & $>3.0$ \\
\hline Mixotrophic grass mires & \multirow{2}{*}{76.2} & 10.0 & 35.0 \\
\hline Mixotrophic quagmires & & 1.0 & $>3.5$ \\
\hline Spring fens & 1.5 & 0.4 & 0.9 \\
\hline Heath moors & 3.0 & 1.5 & 1.2 \\
\hline Bogs & 250.0 & 158.0 & $>152.0$ \\
\hline$\sum$ total & 642.2 & 193.9 & $>232.9$ \\
\hline
\end{tabular}

According to Ilomets (2010) and Ilomets et al. (2015; Table 1), almost all fen types are affected by drainage for agriculture. Many spring fens are influenced by decreased groundwater discharge due to drainage in the surrounding areas. Most transitional (mixotrophic) fens have been turned into pasture. The wooded transitional mires are seriously affected by drainage for forestry (Ilomets 2015). In the 1950s and 1960s, most Estonian bogs were affected by drainage at their margins. The drainage effect has decreased with time as the ditches filled up, but has turned many formerly open marginal bog slopes into bog forests (Ilomets 2015). Mainly because of nature conservation efforts in the 1970s, $60-65 \%$ of the bog sites still remain in an undrained state (Ilomets 2010 and Ilomets et al. 2015; Table 1, 6 and 7).

Paal \& Leibak (2011) regard the assessment of undrained peatlands (mires) from Ilomets et al. (2010) as too strict and pessimistic (Table 1), because they "have only considered mires in good natural state." Paal \& Leibak (2011) also included "destroyed but still surviving habitats" in their calculations of the total mire area and consequently arrived at higher area estimates for most mire habitat site types (Table 1). However, both studies arrive at a loss of two third of the mire area of Estonia between the 1950s and 2010/2011 (cf. Table 6). 
Table 2: Threatened communities of mires and rich paludifying grasslands (Paal \& Leibak 2011). Rarity: 0 =extinct or probably extinct; $1=$ =very rare; 2 =rare; 3=fairly rare; 4=approaching rare. Degree of threat: 1 =very threatened; $2=$ threatened; $3=$ fairly threatened

\begin{tabular}{|c|c|c|c|c|}
\hline Site type & Community type & Distribution & Rarity & $\begin{array}{r}\text { Degree of } \\
\text { threat }\end{array}$ \\
\hline Poor fens & Caricetum flavae & locally, mainly in E-Estonia & 4 & 3 \\
\hline \multirow[t]{7}{*}{ Rich fens } & Caricetum davallianae & $\begin{array}{l}\text { mainly on western Islands, in } \\
\text { mainland scarcely; on northern } \\
\text { distribution limit }\end{array}$ & 4 & 2 \\
\hline & Caricetum hostianae & $\begin{array}{l}\text { in W- and NW-Estonia, near } \\
\text { north-eastern distribution limit }\end{array}$ & 4 & 2 \\
\hline & Caricetum buxbaumii & in W-Estonia & 3 & 2 \\
\hline & Cladietum marisci & $\begin{array}{l}\text { mainly on western Islands, on } \\
\text { northern distribution limit }\end{array}$ & 3 & 2 \\
\hline & Schoenetum nigricantis & $\begin{array}{l}\text { on Islands Saaremaa and } \\
\text { Hiiumaa; on northern } \\
\text { distribution limit }\end{array}$ & 2 & 2 \\
\hline & Rhynchosporetum fuscae & in NW-Estonia & 1 & 1 \\
\hline & Primulo-Seslerietum & $\begin{array}{l}\text { mainly in } \mathrm{W}-, \mathrm{N} \text { - and } \mathrm{NE}- \\
\text { Estonia; on western Islands }\end{array}$ & 4 & 3 \\
\hline $\begin{array}{l}\text { Minerotrophic } \\
\text { quagmires }\end{array}$ & $\begin{array}{l}\text { Scorpidio-Schoenetum } \\
\text { ferruginei }\end{array}$ & $\begin{array}{l}\text { in W-Estonia and on western } \\
\text { Islands }\end{array}$ & 3 & 2 \\
\hline \multirow[t]{4}{*}{ Spring fens } & $\begin{array}{l}\text { Scorpidio-Schoenetum } \\
\text { ferruginei }\end{array}$ & $\begin{array}{l}\text { in W-Estonia and on western } \\
\text { Islands }\end{array}$ & 3 & 2 \\
\hline & Juncetum subnodulosae & $\begin{array}{l}\text { on Saaremaa Island; on north- } \\
\text { eastern distribution limit }\end{array}$ & 1 & 1 \\
\hline & Caricetum davallianae & $\begin{array}{l}\text { mainly on western Islands; on } \\
\text { northern distribution limit }\end{array}$ & 3 & 2 \\
\hline & Primulo seslerietum & $\begin{array}{l}\text { mainly on western Islands; } \\
\text { in W-, NW-, and N-Estonia }\end{array}$ & 4 & 3 \\
\hline \multirow[t]{3}{*}{$\begin{array}{l}\text { Rich Paludify- } \\
\text { ing Grasslands }\end{array}$} & Caricetum hostianae & $\begin{array}{l}\text { in W-and NW-Estonia, near } \\
\text { north-eastern distribution limit }\end{array}$ & 4 & 2 \\
\hline & Caricetum davallianae & $\begin{array}{l}\text { mainly on western Islands; on } \\
\text { northern distribution limit }\end{array}$ & 4 & 3 \\
\hline & Primulo seslerietum & $\begin{array}{l}\text { mainly on western Islands; } \\
\text { in } \mathrm{W}-, \mathrm{NW}-\text {, and } \mathrm{N}-\text {-Estonia }\end{array}$ & 4 & 3 \\
\hline
\end{tabular}

Table 2 gives the results of the assessment of rarity and degree of threat of Estonian mire types and paludifying grasslands (Paal \& Leibak 2011). The most rare and threatened community types are the Schoenetum nigricantis, the Rhynchosporetum fuscae (rich fens) and the Juncetum subnodulosae (spring fens), which partly also approach their northern or north-eastern area limits in Estonia. 


\subsubsection{Current peatland: location, extent, status, land use and greenhouse gas emissions}

\section{Material and Methods}

To assess the location and extent of "peatlands" 2 we combined two GIS datasets:

- The Estonian Soil Map (scale 1:10,000; Estonian Land Board 2001), from which we extracted the types: "M" - fen peat and "A" - alluvial fen peat, which we combined as fen peat, " $\mathrm{S}$ " transitional mire peat, and "R" - raised bog peat.

- The Land use dataset (Estonian Land Board 2011), to include the peat extraction areas, which were (with some exceptions) virtually missing in the Estonian soil map.

To assess land use, we extracted the following shapes from the Estonian base map (1:10,000; Estonian Land Board 2011):

- "Streamlines", with drainage systems, incl. rivers, brooks, ditches and channels of 1-8 m wide.

- "Forest distribution" to identify forested "peatlands".

The drainage impact on adjacent "peatlands" was assumed to extent to $200 \mathrm{~m}$ from each streamline (cf. Eggelsmann 1982; see also NIS Iceland 2014). Although most drainage systems are artificial, the inclusion of rivers and brooks may have led to some overestimation of the drained area.

By overlay analysis we thus distinguished the following land use types of "peatlands" (Table 3):

- undrained open

- drained agriculture

- undrained forested

${ }^{2}$ The included "alluvial fen peat" does not meet the definition of peatland as having $>30$ thickness of peat layer (§ 2.1.). 
- drained forested

- drained peat extraction (active)

- drained peat extraction (abandoned).

Table 3: Overlay analysis of the "peatland" data from the Estonian Soil Map with the Land use datasets (see above). Land use types do not correspond to UNFCCC/IPCC land use categories

\begin{tabular}{|c|c|c|c|c|c|c|c|}
\hline \multirow[b]{2}{*}{$\begin{array}{l}\text { Land use types in our GIS } \\
\text { study }\end{array}$} & \multicolumn{4}{|c|}{ "Peatland" data } & \multicolumn{3}{|c|}{ Land use data } \\
\hline & Bog & Transitional & Fen & $\begin{array}{l}\text { Unde- } \\
\text { fined }\end{array}$ & $\begin{array}{l}\text { For- } \\
\text { est }\end{array}$ & $\begin{array}{l}\text { Stream- } \\
\text { lines with } \\
\text { impact } \\
\text { zone }\end{array}$ & $\begin{array}{l}\text { Peat } \\
\text { extrac- } \\
\text { tion }\end{array}$ \\
\hline undrained open & $x$ & $x$ & $x$ & & & & \\
\hline undrained forested & $x$ & $x$ & $x$ & & $x$ & & \\
\hline drained forested & $x$ & $x$ & $x$ & & $x$ & $x$ & \\
\hline drained agriculture & $x$ & $x$ & $x$ & & & $x$ & \\
\hline peat extraction (active) & $x$ & $x$ & $x$ & $x$ & & $x$ & $x$ \\
\hline peat extraction (abandoned) & $x$ & $x$ & $x$ & $x$ & & $x$ & $x$ \\
\hline
\end{tabular}

For error analysis, we visually checked the accuracy of the GIS dataset from the Estonian Soil Map (see above) with regard to position of borders and accuracy of "peatland" areas against orthophotos of the Estonian Map service (Estonian Land Board 2013) for five randomly selected areas with a diameter of $10 \mathrm{~km}$. It appeared that, in general, the dataset represents the "peatlands" sufficiently, but peat extraction areas were barely covered and incompletely represented by the extracted "peatland" data from the Estonian Soil Map, implying that their real extent is larger than calculated in our GIS study (23.6 x $10^{3}$ ha; see Discussion below).

We additionally considered the land use area data on drained organic soils from:

- the recent National Inventory Submission of Estonia to the United Nations Framework Convention on Climate Change (UNFCCC; NIS 3 Estonia 2014). ${ }^{4}$

The NFI is a systematic collection of forest information based on randomly distributed permanent sample plots that cover the whole country and all

3 The National Inventory Submission ("NIS") consists of the National Inventory Report ("NIR") and the Common Reporting Format ("CRF"). Since the NIR and the CRF were used, it will be referred below to the complete National Inventory Submission of Denmark as NIS “Estonia” (2014).

${ }^{4}$ https://unfccc.int/national_reports/annex_i_ghg_inventories/national_inventories_submissions/items/ 8108.php 
land use classes. The NFI also provides information on soils: distribution of mineral and organic soils as well as their drainage status (drained, undrained). Methodologically, the NFI is designed as an annual research effort, which, using optimal methods must ensure the continuous updating of information and the forest database. $20 \%$ of the sample plots in the network (in totally approximately 275 clusters with ca. 4,300 sample plots) are assessed every year, so that all plots are re-visited every 5 years. The observations from the sample plots are extrapolated to the entire population (cf. Figure 7.5 of NIS Estonia 2014).

Emissions were calculated using the IPCC (2014) default emission factors for $\mathrm{CO}_{2}$ for the Temperate climate/vegetation zone for Estonia, which is in line with the IPCC climate classification. As the available land use data of our GIS overlay analysis (Table 3,7 ) and the land use area data on peatland from Paal \& Leibak (2011, Table 9) do not distinguish between cropland and grassland, we used for "drained agriculture" an average default value of all emission factors for Cropland and Grassland (except EF “Grassland, shallow drained, nutrient-rich," IPCC 2014; Table 4). To compensate for some overestimation of the drained area in our GIS study, we conservatively assumed shallow drainage for the agriculturally used fens (169.5 x $10^{3}$ ha; see Table 7). Thus, we applied the related IPCC (2014) emission factor for $\mathrm{CO}_{2}$ for shallow drainage $(13.2 \mathrm{t}$ $\mathrm{CO}_{2}$ ha), because the agricultural used area of our GIS overlay study also includes drainage affected "peatlands" due to the $200 \mathrm{~m}$ impact zone to the ditches (see above).

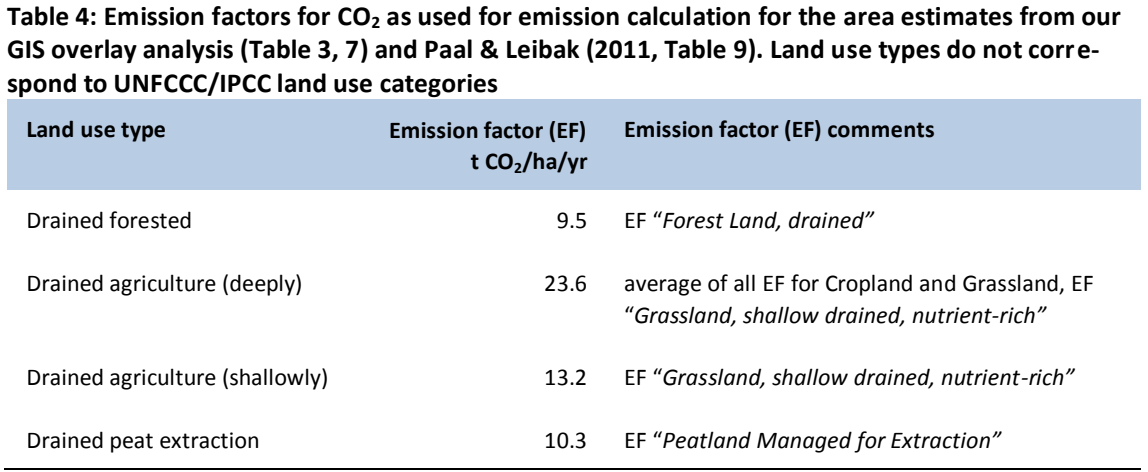

Table 5 shows the emission factors for $\mathrm{CO}_{2}$ for drained organic soils as applied in NIS Estonia (2014), and the Tier 1 emission factors from IPCC 
(2014) as applied for emission recalculation based on the area estimates on drained organic soils as given in NIS Estonia (2014, Table 8). Because Estonia belongs to the Temperate, Moist climate/vegetation zone $^{5}$ according to IPCC, we did not apply the Tier 2 emission factors from Sweden as done in NIS Estonia (2014). This emission recalculation resulted in approximately five times higher annual emissions (see Table 8).

\begin{tabular}{|c|c|c|}
\hline \multirow[t]{2}{*}{ IPCC category } & \multicolumn{2}{|c|}{ Emission factors for $\mathrm{CO}_{2}$ in $\mathrm{t} \mathrm{CO}_{2} / \mathrm{ha} / \mathrm{yr}$} \\
\hline & NIS Estonia (2014) & IPCC (2014) \\
\hline Forest Land remaining Forest Land & 1.0 & 9.5 \\
\hline Grassland converted to Forest Land & 2.1 & \\
\hline Cropland & 18.3 & 29.0 \\
\hline Grassland remaining Grassland & 3.3 & $20.9^{1)}$ \\
\hline Forest Land converted to Grassland & 5.9 & \\
\hline Peat extraction & 6.4 & 10.3 \\
\hline
\end{tabular}

${ }^{1)}$ Deeply drained: average of EF "Grassland, drained, nutrient-poor" and "Grassland, deep-drained, nutrient-rich" (excl. EF "Grassland, shallow drained, nutrient-rich" from IPCC 2014).

We did not include carbon loss from DOC (Dissolved Organic Carbon). Peat carbon stocks were derived from Paal \& Leibak (2011).

\section{Results}

The GIS overlay analysis (Table 3) shows that Estonian peatlands in total cover $915.0 \times 10^{3}$ ha, including $218.0 \times 10^{3}$ ha of bog, $531.2 \times 10^{3}$ ha of fen and $149.7 \times 10^{3}$ ha of transitional peatland (Table 6). The largest concentrations occur around Pärnu, North and South of Lake Peipsi, north of Lake Võrtsjärv, and North and West of the town of Paide in Central Estonia (Figure 2). 
Table 6: Area, drainage status and emissions of peatland ${ }^{6}$ types in Estonia (our GIS overlay analysis, Table 3). For details see Table 7 (below). Land use types do not correspond to UNFCCC/IPCC land use categories

\begin{tabular}{|c|c|c|c|c|c|c|}
\hline \multirow[b]{2}{*}{ Peatland and Land use type } & \multirow{2}{*}{$\begin{array}{l}\text { Total Area } \\
\qquad 10^{3} \text { ha }\end{array}$} & \multicolumn{2}{|c|}{ Undrained area } & \multicolumn{2}{|c|}{ Drained area } & \multirow{2}{*}{$\begin{array}{l}\text { Emissions } \\
\mathrm{Mt} \mathrm{CO}_{2} / \mathrm{yr}\end{array}$} \\
\hline & & $10^{3}$ ha & $\%$ & $10^{3}$ ha & $\%$ & \\
\hline Bog & 218.01 & 142.60 & 65.4 & 75.41 & 34.6 & 1.47 \\
\hline Transition & 149.70 & 53.82 & 36.0 & 95.88 & 64.0 & 1.24 \\
\hline Fen & 531.18 & 87.30 & 16.4 & 443.88 & 83.6 & 4.85 \\
\hline $\begin{array}{l}\text { "Undefined peatland" } \\
\text { active extraction }\end{array}$ & 11.20 & 0.0 & 0.0 & 11.20 & 10.0 & 0.12 \\
\hline Abandoned extraction & 4.90 & 0.0 & 0.0 & 4.90 & 100.0 & 0.05 \\
\hline Subtotals & & 283.72 & 31.0 & 631.28 & 69.0 & \\
\hline Total & & & & & 915.00 & 7.73 \\
\hline
\end{tabular}

According to our GIS overlay analysis (Table 3) 69\% of the Estonian peatlands are directly or indirectly impacted by drainage (Table 6). In total, $23.64 \times 10^{3}$ ha of peatland were identified as extraction areas, with $6.39 \times 10^{3}$ ha classified as bog, $0.41 \times 10^{3}$ ha as transition peatland and $0.73 \times 10^{3}$ ha as fen. The remaining $16.11 \times 10^{3}$ ha could not be attributed to these types ("undefined peatland"; see Table 6; Material and Methods above), but can be assumed to be largely bogs.

Of the $218.01 \times 10^{3}$ ha of Estonian bogs, $142.60 \times 10^{3}$ ha (65.4\%) still remain in an undrained state with open or woody vegetation (Figure 3 ), whereas $75.41 \times 10^{3}$ ha (34.6\%) is drained and used for forestry or agriculture (Table 7). Transitional peatlands cover $149.70 \times 10^{3}$ ha, of which $53.82 \times 10^{3}$ ha $(36.0 \%)$ remain in an undrained state with open or woody vegetation (Figure 4). $95.88 \times 10^{3}$ ha $(64 \%)$ is used for forestry or agriculture (Table 7). Fens cover in total $531.18 \times 10^{3}$ ha, of which $87.30 \times 10^{3}$ ha (16.4\%) still remains in an undrained state with open or woody vegetation (Figure 3). $443.88 \times 10^{3}$ ha (83.6\%) of the total fen area is used for forestry or agriculture (Table 7 ).

According to our analysis the total annual anthropogenic $\mathrm{CO}_{2}$ emissions from Estonian peatlands amount to $7.7 \mathrm{Mt} \mathrm{CO}_{2}$ of which $1.5 \mathrm{Mt}$ are attributable to bogs, $1.2 \mathrm{Mt}$ to transitional peatlands and 4.8 Mt to fens (Table 6, 7).

\footnotetext{
${ }^{6}$ Area data excluding "alluvial fen peats" with $<30 \mathrm{~cm}$ peat layer (see Material and Methods [above], and Discussion [below]).
} 
Figure 2: Location and extent of "peatlands" 7 in Estonia, specified for A) "peatland" type ("Undefined peatlands" are peat extraction sites) and B) land use type (our GIS overlay analysis, Table 3). Land use types do not correspond to UNFCCC/IPCC land use categories
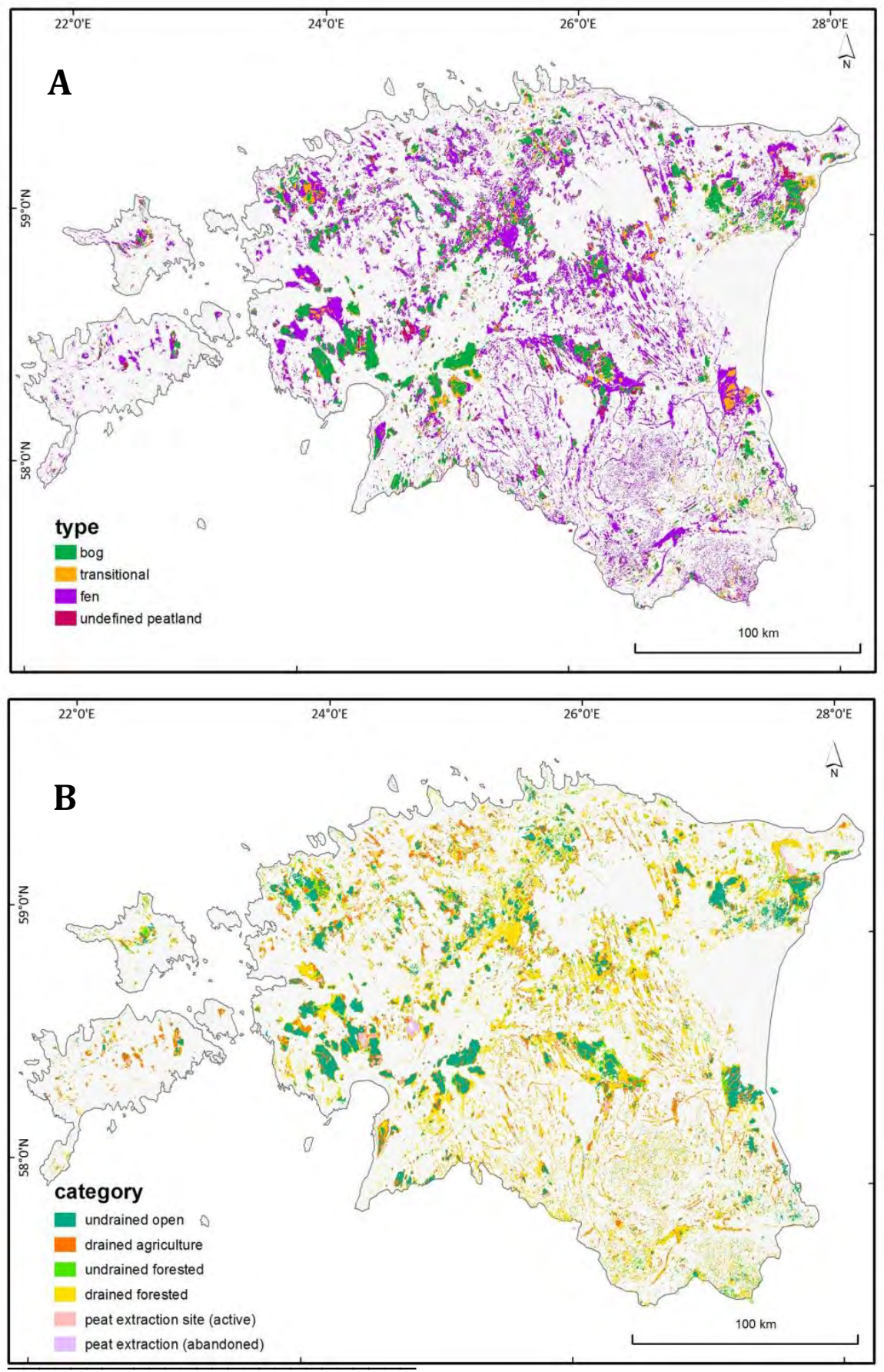

7 Maps including "alluvial fen peat" with $<30 \mathrm{~cm}$ peat thickness (see Material and Methods [above], and Discussion [below]). 
Figure 3: Location, extent and drainage status of Estonian bogs and fens ${ }^{8}$ (our GIS overlay analysis, Table 3)
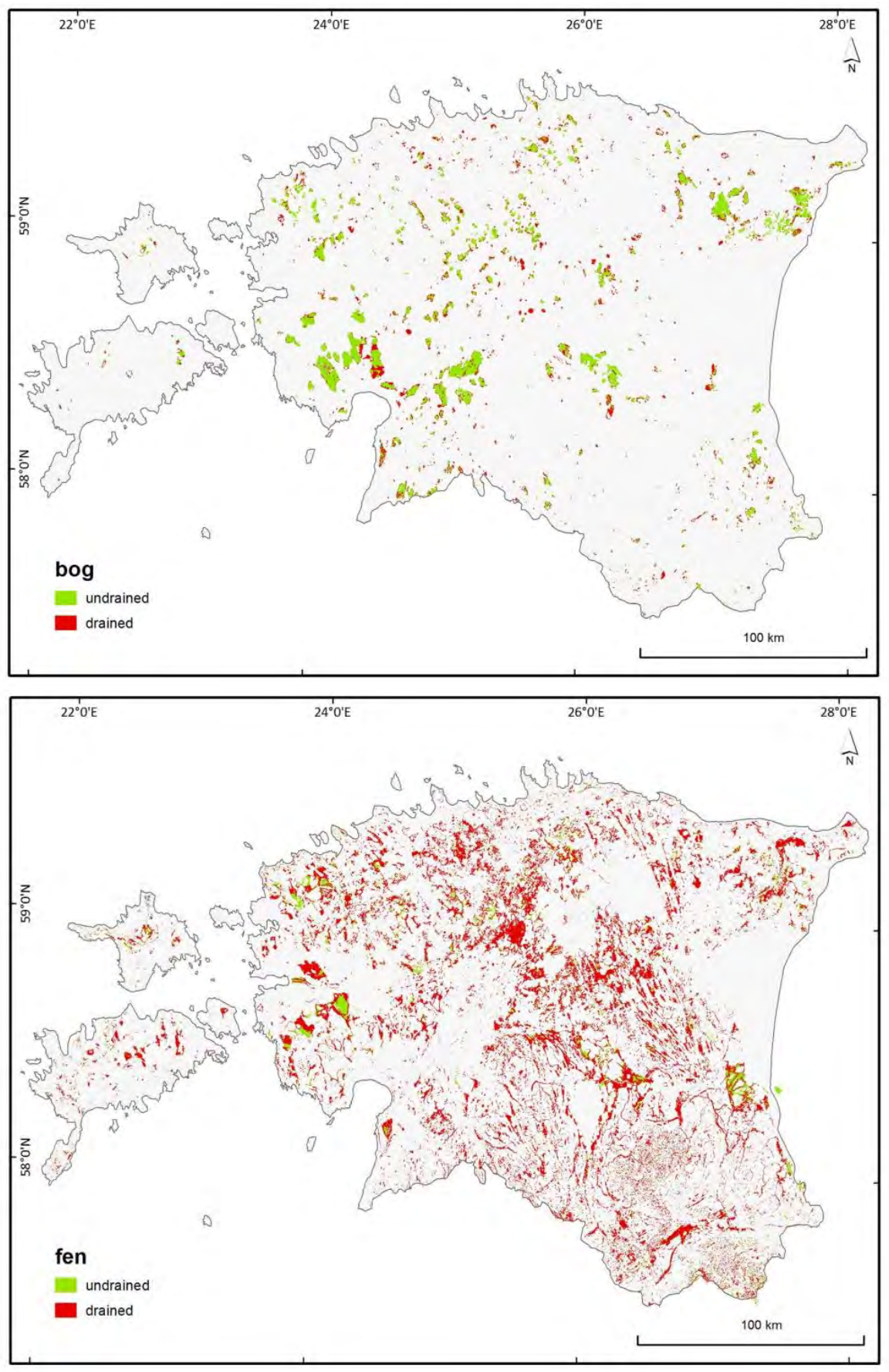

${ }^{8}$ Maps including "alluvial fen peat" with $<30 \mathrm{~cm}$ peat thickness (see Material and Methods [above], and Discussion [below]). 
Figure 4: Location, extent and drainage status of Estonian transition and "undefined peatlands" 9 (the latter are peat extraction sites; our GIS overlay analysis; Table 3)
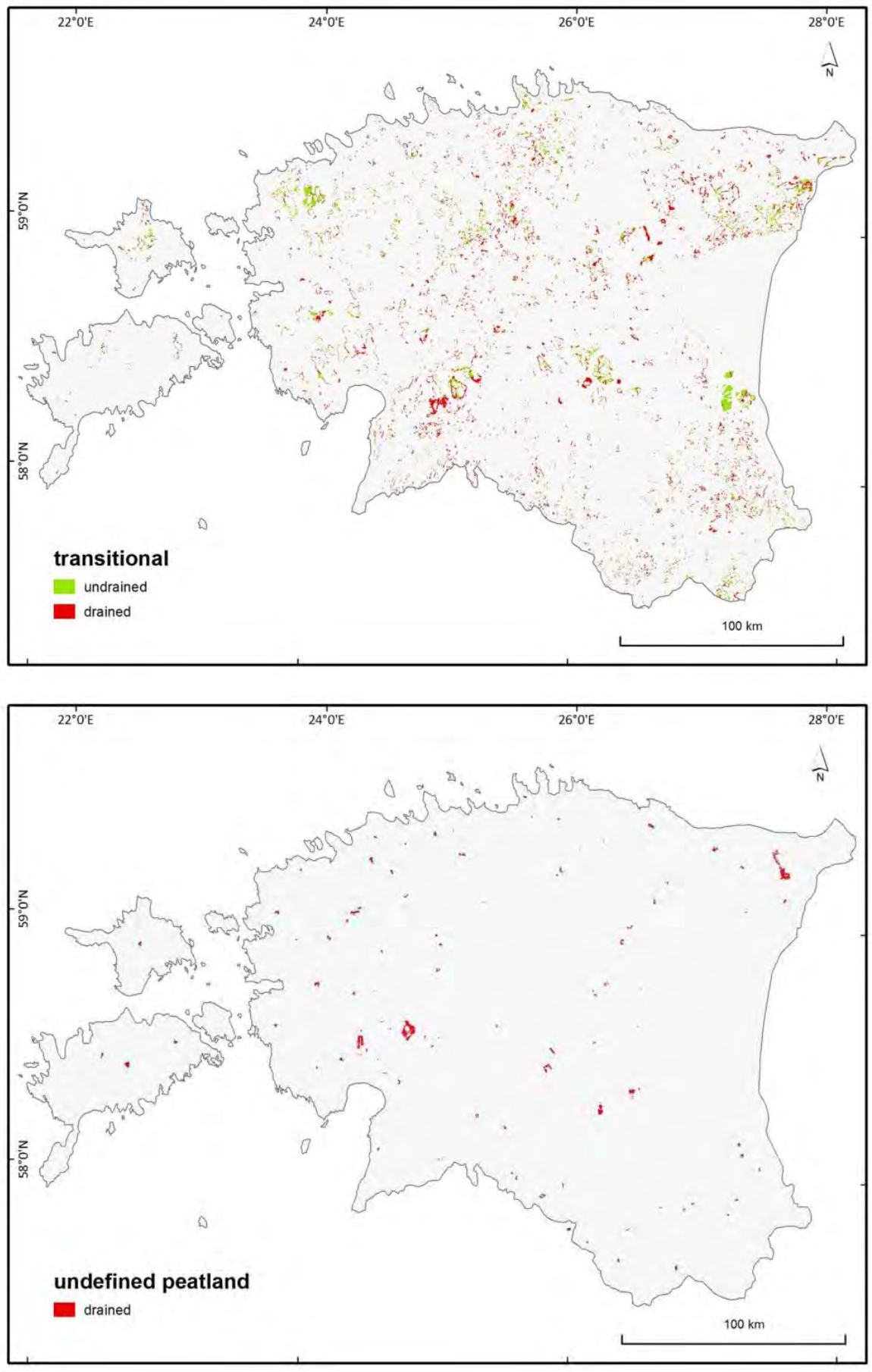

${ }^{9}$ Maps including "alluvial fen peat" with $<30 \mathrm{~cm}$ peat thickness (see Material and Methods [above], and Discussion [below]). 


\section{Discussion}

Our GIS overlay analysis (Table 3) resulted in a total peatland area of 991.0 $\mathrm{x} 10^{3}$ ha. Since the "peatland" data (from the Estonian Soil Map, see Material and Methods above) includes "alluvial fen peat" with a peat thickness of $<30 \mathrm{~cm}$, the value for proper peatland was recalculated to $915.0 \times 10^{3}$ ha following Paal \& Leibak (2011), who present this value for the current extent of peatlands with $>30 \mathrm{~cm}$ of peat (= peatlands according to $\S 2.1$.). The difference between the total "peatland" area from our GIS overlay analysis $\left(991.0 \times 10^{3} \mathrm{ha}\right)$ and the total peatland area given by Paal \& Leibak (2011; $915.0 \times 10^{3}$ ha) was $76.0 \times 10^{3}$ ha, which we subtracted from the "peatland" type fen ${ }^{10}$ in our GIS overlay analysis (Table 6, 7). Thus, the area of "fen" was reduced by the recalculation from 607.2 to $531.2 \times 10^{3}$ ha (Table 6, 7). According to Paal \& Leibak (2011) the area of undisturbed mires ${ }^{11}$ had in 2011 decreased to $233.0 \times 10^{3}$ ha. This implies that - in relation to the entire peatland area in Paal \& Leibak (2011) of $915.0 \times 10^{3}$ ha $-682.1 \times 10^{3}$ ha of peatlands are drained and affected by land use. This figure fits rather well with the (recalculated) $631.3 \times 10^{3}$ ha of peatlands from our GIS overlay analysis (Table 6, 9).

According to Paal \& Leibak (2011) peat extraction covers $54.30 \times 10^{3}$ ha ( $44.9 \times 10^{3}$ ha active, $9.4 \times 10^{3}$ ha abandoned sites (Table 9), with related annual emissions of $0.56 \mathrm{Mt} \mathrm{CO}_{2}$. In contrast, our GIS overlay analysis arrives at $23.6 \times 10^{3}$ ha and $0.24 \mathrm{Mt} \mathrm{CO}_{2} / \mathrm{yr}$, whereas the National Inventory Submission for Estonia (NIS Estonia 2014) to the Climate Convention UNFCCC reports $18.6 \times 10^{3}$ ha and $0.19 \mathrm{Mt} \mathrm{CO}_{2} / \mathrm{yr}$. The NIS bases its information on the statistical, i.e. not spatially explicit approach of the National Forest Inventory (NFI, see Material and Methods above).

The NIS Estonia (2014) reports $221.7 \times 10^{3}$ ha of Forest Land on drained organic soil, $22.6 \times 10^{3}$ ha of Cropland on drained organic soil, $21.5 \times 10^{3}$ ha of Grassland on drained organic soil and $18.6 \times 10^{3}$ ha of organic soil drained for Peat extraction. The total $284.5 \times 10^{3}$ ha of drained organic soil in the NIS Estonia (2014) is by far lower than the $631.3 \times 10^{3}$ ha of drained peatland we have elaborated in our GIS overlay analysis $($ Table 3,6$)$. This difference cannot completely be be explained by the fact that our analysis includes peatland fallows and unused areas affected by drainage of adjacent peatlands (see Material and Methods above). Also, the peatland datasets we have used seem to be

\footnotetext{
10 In land use type "drained forested".

11 Mind that mires are defined as having a peat thickness of $>30 \mathrm{~cm}$ (Paal \& Laibak 2011).
} 
accurate regarding the polygon borders (see Material and Methods above). Furthermore, the resulting $631.3 \times 10^{3}$ ha of drained peatland from our GIS analysis are in line with the total drained peatland area as reported by Paal \& Leibak (2011) and Vasander et al. (2003; Table 9).

This would finally mean that the NIS Estonia (2014) underestimates the area of drained organic soil by more than $50 \%$. The largest difference in area data was found for agriculture, for which NIS Estonia (2014) reports only $44.2 \times 10^{3}$ ha (Cropland + Grassland), whereas our GIS analysis suggests $240.0 \times 10^{3}$ ha, Vasander et al. (2003) about 269.0 $\times 10^{3}$ ha, and the official FAO statistics $384.0 \times 10^{3}$ ha (Cropland + Grassland), ${ }^{12}$ respectively (Table 9). Also Ilomets (2015) estimates the area of peatlands that have been drained and brought into agricultural production as cultivated grassland, pasture and arable land to $250.0-300.0 \mathrm{x}$ $10^{3}$ ha.Drainage and land use of organic soils lead according to the NIS Estonia (2014) to an annual $\mathrm{CO}_{2}$ emission of $0.8 \mathrm{Mt}$ (Table 8), whereas we would arrive at a total of 3.4 Mt (Table 6, 7), while using the area data as given in NIS Estonia (2014). This is caused by the fact that the NIS Estonia (2014) uses the IPCC default values and Swedish national values from the Boreal climate/vegetation zone, whereas we applied the latest IPCC (2014) emission factors for $\mathrm{CO}_{2}$ for the Temperate climate/vegetation zone. According to IPCC, 13 Estonia belongs to the $\mathrm{Cool}$ Temperate, Moist Climate. Major increases occurred in the categories Forest Land remaining Forest Land and Grassland remaining Grassland.

${ }^{12}$ See http://faostat.fao.org/site/739/DesktopDefault.aspx?PageID=739\#ancor

${ }^{13}$ See http://eusoils.jrc.ec.europa.eu/projects/RenewableEnergy/ 
Table 7: Extent of Estonian bogs, fens and transitional peatlands and associated $\mathrm{CO}_{2}$ emissions for various types of land use (our GIS overlay analysis, see Table 3; emission factors based on IPCC 2014 for the Temperate climate/vegetation zone, see Material and Methods above)

\begin{tabular}{|c|c|c|c|}
\hline Peatland type & $\begin{array}{r}\text { Area } \\
\left(10^{3} \text { ha }\right)\end{array}$ & $\begin{array}{l}\text { Emission factor } \\
\left(\mathrm{t} \mathrm{CO}_{2} / \mathrm{ha} / \mathrm{yr}\right)\end{array}$ & $\begin{array}{r}\text { Emissions } \\
(\mathrm{Mt} \mathrm{CO} / \mathrm{yr})\end{array}$ \\
\hline \multicolumn{4}{|l|}{ Bog } \\
\hline undrained open & 137.35 & \pm 0 & \pm 0 \\
\hline drained agriculture (deeply drained) & 53.33 & 23.6 & 1.25 \\
\hline undrained forested & 5.25 & \pm 0 & \pm 0 \\
\hline drained forested & 15.70 & 9.5 & 0.15 \\
\hline peat extraction (active) & 5.45 & 10.3 & 0.06 \\
\hline peat extraction (abandoned) & 0.94 & 10.3 & 0.01 \\
\hline ¿subtotal & 218.01 & & 1.47 \\
\hline \multicolumn{4}{|l|}{ Transitional } \\
\hline undrained open & 32.26 & \pm 0 & \pm 0 \\
\hline drained agriculture (deeply drained) & 23.20 & 23.6 & 0.54 \\
\hline undrained forested & 21.56 & \pm 0 & \pm 0 \\
\hline drained forested & 72.26 & 9.5 & 0.69 \\
\hline peat extraction (active) & 0.25 & 10.3 & 0.00 \\
\hline peat extraction (abandoned) & 0.16 & 10.3 & 0.00 \\
\hline$\sum$ subtotal & 149.70 & & 1.24 \\
\hline \multicolumn{4}{|l|}{ Fen } \\
\hline undrained open & 36.85 & \pm 0 & \pm 0 \\
\hline drained agriculture (shallowly drained) & 169.48 & 13.2 & 2.24 \\
\hline undrained forested & 50.45 & \pm 0 & \pm 0 \\
\hline drained forested & 349.66 & 9.5 & 3.33 \\
\hline drained peat extraction (active) & 0.34 & 10.3 & 0.00 \\
\hline drained peat extraction (abandoned) & 0.39 & 10.3 & 0.00 \\
\hline$\sum$ subtotal & 531.18 & & 4.85 \\
\hline \multicolumn{4}{|l|}{ Undefined peatland } \\
\hline peat extraction (active) & 11.20 & 10.3 & 0.12 \\
\hline peat extraction (abandoned) & 4.90 & 10.3 & 0.05 \\
\hline$\sum$ subtotals & 16.11 & & 0.17 \\
\hline$\Sigma$ total & 915.00 & & 7.73 \\
\hline
\end{tabular}


Table 8: Drained organic soil areas, land use types and associated $\mathrm{CO}_{2}$ emissions. Left part of the table: as reported in the NIS Estonia (2014), right part: recalculation of emi ssions with the new IPCC (2014) default values for $\mathrm{CO}_{2}$

\begin{tabular}{|c|c|c|c|c|c|c|c|c|}
\hline \multirow[t]{2}{*}{ Estonia } & \multicolumn{6}{|c|}{ National Inventory Submission (NIS Estonia 2014) } & \multicolumn{2}{|c|}{$\begin{array}{l}\text { Recalculated according to } \\
\text { IPCC } 2014\end{array}$} \\
\hline & $\begin{array}{r}\text { Area of organic } \\
\text { soil }\left(10^{3} \mathrm{ha}\right)\end{array}$ & $\begin{array}{l}\text { Net carbon stock change } \\
\text { per area }\left(\mathrm{t} \mathrm{CO}_{2} / \mathrm{ha} / \mathrm{yr}\right)\end{array}$ & $\begin{array}{r}\text { Emissions } \\
(\mathrm{Mt} \mathrm{CO} / \mathrm{yr})\end{array}$ & $\begin{array}{r}\text { EF } \\
\text { TIER }\end{array}$ & $\begin{array}{l}\text { Uncertainty } \\
\text { area data \% }\end{array}$ & $\begin{array}{r}\text { Uncertainty } \\
\text { EF \% }\end{array}$ & $\begin{array}{l}\text { Net carbon stock change } \\
\text { per area }\left(\mathrm{t} \mathrm{CO}_{2} / \mathrm{ha} / \mathrm{yr}\right)\end{array}$ & $\begin{array}{r}\text { Emissions } \\
(\mathrm{Mt} \mathrm{CO} / \mathrm{yr})\end{array}$ \\
\hline \multicolumn{9}{|l|}{ Land use category } \\
\hline Forest Land remaining Forest Land & 218.23 & 1.0 & 0.22 & 2 & 4.3 & 35 & 9.5 & 2.08 \\
\hline Grassland converted to Forest Land & 0.66 & 2.1 & 0.00 & & 73.8 & 35 & 9.5 & 0.01 \\
\hline Wetlands converted to Forest Land & 2.65 & 2.1 & 0.01 & & 39.5 & 35 & 9.5 & 0.03 \\
\hline Settlement converted to Forest Land & 0.23 & 2.1 & 0.00 & & 138.6 & 35 & 9.5 & 0.00 \\
\hline$\sum$ Forest Land & 221.76 & & 0.22 & & & & & 2.11 \\
\hline Cropland remaining Cropland & 21.93 & 18.3 & 0.40 & & 24.4 & 90 & 29.0 & 0.64 \\
\hline Grassland converted to Cropland & 0.70 & 18.3 & 0.01 & & 138.6 & & 29.0 & 0.02 \\
\hline$\sum$ Cropland & 22.63 & & 0.41 & & & & & 0.66 \\
\hline Grassland remaining Grassland & 19.18 & 3.3 & 0.06 & 2 & 16.8 & 35 & 20.9 & 0.40 \\
\hline Forest Land converted to Grassland & 0.14 & 5.9 & 0.00 & & 45.7 & 35 & 20.9 & 0.00 \\
\hline Cropland converted to Grassland & 1.74 & 5.9 & 0.01 & 1 & & & 20.9 & 0.04 \\
\hline Wetlands converted to Grassland & 0.42 & 5.9 & 0.00 & 2 & & & 20.9 & 0.01 \\
\hline Settlement converted to Grassland & 0.04 & 5.9 & 0.00 & & & & 20.9 & 0.00 \\
\hline$\sum$ Grassland & 21.53 & & 0.08 & & & & & 0.45 \\
\hline \multicolumn{9}{|l|}{ Wetlands remaining Wetlands } \\
\hline Peatland = peat extraction sites & 15.59 & 6.4 & 0.10 & 2 & 22.8 & 50 & 10.3 & 0.16 \\
\hline Forest Land converted to Peatland & 2.57 & 6.4 & 0.02 & & 102.8 & 47 & 10.3 & 0.03 \\
\hline Wetlands converted to Peatland & 0.43 & 6.4 & 0.00 & & 74.1 & 50 & 10.3 & 0.00 \\
\hline$\sum$ Peat Extraction & 18.59 & & 0.12 & & & & & 0.19 \\
\hline$\sum$ Total & 284.51 & & 0.83 & & & & & 3.41 \\
\hline
\end{tabular}


Table 9: Areas of drained peatlands (our GIS overlay analysis; Paal \& Leibak 2011), and organic soils (NIS Estonia 2014) in Estonia. Land use types only corresponding to UNFCCC/IPCC land use categories for the data from NIS Estonia (2014)

\begin{tabular}{|c|c|c|c|c|c|c|}
\hline \multirow[b]{2}{*}{ Land use type } & \multicolumn{4}{|c|}{ Area per land use type $\left(10^{3} \mathrm{ha}\right)^{7)}$} & \multicolumn{2}{|c|}{$\begin{array}{l}\text { Total drained peatland (left; our analysis + Paal \& Leibak } \\
\text { 2011) and related emissions (right) }\end{array}$} \\
\hline & $\begin{array}{l}\text { NIS Estonia } \\
(2014)^{1)}\end{array}$ & $\begin{array}{r}\text { Our GIS overlay analysis } \\
\text { (Table 3) }\end{array}$ & $\begin{array}{r}\text { Paal \& Leibak } \\
\text { (2011) }\end{array}$ & $\begin{array}{r}\text { Vasander et al. } \\
\text { (2003) }\end{array}$ & $10^{3}$ ha & (Mt $\mathrm{CO}_{2} / \mathrm{yr}$ ) \\
\hline undrained peatland, open & & 206.46 & & & & \\
\hline undrained peatland, forestry & & 77.26 & & & & \\
\hline$\sum$ subtotal undrained peatland & & 283.72 & 233.00 & & & \\
\hline drained peatland, agriculture & & $240.01^{2)}$ & & 269.01 & 240.01 & $3.45^{51}$ \\
\hline drained peatland, forestry & & $361.64^{8)}$ & & 313.85 & 361.64 & $4,03^{6)}$ \\
\hline drained peatland, peat extraction & & $23.64^{4)}$ & 54.30 & 60.85 & 54.30 & 0.56 \\
\hline$\sum$ subtotal drained peatland & & 631.28 & 682.00 & 640.5 & 661.94 & 8.04 \\
\hline$\Sigma$ total peatland & & 915.00 & 915.00 & & & \\
\hline drained organic soil, Forest Land & 221.76 & & & & & \\
\hline drained organic soil, Cropland & 22.63 & & & & & \\
\hline drained organic soil, Grassland & 21.53 & & & & & \\
\hline drained organic soil, Peat extraction ${ }^{3)}$ & $18.59^{4)}$ & & & & & \\
\hline$\sum$ subtotal drained organic soil & 284.51 & & & & & \\
\hline
\end{tabular}

${ }^{1)}$ All data (except for Forest Land) is taken from the "Common Reporting Format" (CRF file) in NIS Estonia (2014), and is explicitly given for organic soils (CRF; Table 5.B-5.D; available at: http://unfccc.int/national_reports/annex_i_ghg_inventories/national_inventories_submissions/items/8108.php)

${ }^{2)}$ Include agriculturally used peatlands, fallows and peatlands affected by adjacent drainage (see also Material and Methods above).

${ }^{3)}$ Both active and abandoned extraction areas.

${ }^{4)}$ Considerably underestimated.

${ }^{5)}$ Sum of emissions from "drained agriculture" (see Table 7).

${ }^{6)}$ Sum of emissions from "drained forested" (see Table 7).

7) Vasander et al. (2003) stated that 70\% of the peatlands of Estonia are drained, with $49 \%$ for forestry, $42 \%$ for agriculture and $9.5 \%$ for Peat extraction.

8)While quoting llomets (2005), Remm (2015) estimated "that $82 \%$ of existing peatland forests have been historically drained a nd as result over $300 \times 10^{3}$ ha of drained forest has been transformed to the decayed peat type." 
Table 9 shows the compiled area data for peatlands and organic soils of Estonia. While integrating the area data for forestry and agriculture from our GIS analysis and the area given for peat extraction by Paal \& Leibak (2011), we arrive at a total of $661.9 \times 10^{3}$ ha of drained peatland in Estonia. Related emissions amount to annually $8.0 \mathrm{Mt} \mathrm{CO}_{2}$ (Table 9). These figures have been chosen as the most realistic ones.

According to Paal \& Leibak (2011) the total peat resources amount to $1.64 \times 10^{9}$ tons (which with an assumed carbon content of 55\% would amount to 902 Mt of Carbon). The Global Peatland Database (Joosten 2009) assumes a peat carbon stock of 919 Mt Carbon for Estonia in 2008. Due to drainage, degradation and peat extraction the peat carbon stock is continuously decreasing.

\subsubsection{Current state of peatland conservation and prospects for peatland restoration}

Although a large proportion of mires have been drained for agriculture and forestry, and some areas are destroyed for peat and oil shale mining, Estonia is still rich in mires, both in terms of their total area and their variety of habitats and structures. During the project Estonian Mires Inventory Completion for Maintaining Biodiversity (2008-2011) the peatland inventory was completed. As a result of this huge effort, a complete overview on all areas covered by mire vegetation in Estonia is available. Furthermore, there is a legislative and administrative framework in place, which supports the sustainable use and conservation of peatlands. The main threats affecting peatlands are addressed in several strategies. The compensation network, where legally protected areas (most of them designated also as Natura 2000 sites) are supplemented by areas included in the green network, ensures the maintenance of the provision of the main peatland ecosystem services.

In 2012, the Government adopted the Nature Conservation Development Plan until 2020, which is the most relevant document on mire conservation and restoration. This document incorporates broader perspectives of mire habitat restoration in protected areas (including Ramsar sites) as well as rehabilitation of abandoned peat extraction sites. According to this Development Plan, $10 \times 10^{3}$ ha peatland habitats in protected areas will be restored by 2020 (especially rich fens and marginal, drained areas surrounding large mire complexes). Furthermore, targets were set to rehabilitate approximately $2.0 \times 10^{3}$ ha of abandoned peat extraction areas as wetlands. Several rehabilitation and restoration projects have started and were to be implemented in drained peatlands 
during 2011-2014, which are also suitable as demonstration sites (for example Soomaa National Park). In the existing peatland Ramsar sites, maintenance and restoration activities are ongoing according to their management plans. An action plan for mires (including restoration, management actions and budgets) will be elaborated in the Ministry of the Environment. There are potentials to update the Ramsar Information Sheets (RIS ${ }^{14}$ ) while using the climate criteria for at least 10 existing peatland Ramsar sites. Additionally, several large peatland areas from a national "shadow list" could be reasonably designated as new Ramsar sites under use of the climate criteria.

\subsubsection{Acknowledgements}

We thank Agu Leivits (Environmental Board Estonia) for the GIS data preparation, their very fast delivery and collaboration during the preparation of this country chapter.

\subsubsection{References}

Eggelsmann R. (1982). Anmerkungen zur Berechnungsmethode der Breite hydrologischer Schutzzonen im Moor. Telma 12: 183-187.

Estonian Land Board (2001). Estonian Soil Map. 1:10,000.

http://geoportaal.maaamet.ee/eng/Maps-and-Data/Estonian-Soil-Map-p316.html.

Estonian Land Board (2011). Estonian Basic map. 1:10,000.

http://geoportaal.maaamet.ee/eng/Maps-and-Data/Topographic-Data/Estonian-

Basic-Map-p306.html

Estonian Land Board (2013). Estonian Orthophotos. 1:5,000-1: 10,000.

http://geoportaal.maaamet.ee/eng/Maps-and-Data/Orthophotos-p309.html.

Hupel A.W. (1777). Topographische Nachrichten von Lief- und Ehstland. Hartknoch, Riga, 628 p.

Ilomets M. (2005). Restoration of Estonian mires - needs, principles and present state. Yearbook of the Estonian Naturalists" Society 83: 72-95.

Ilomets M. (2015). Estonia. In: Joosten H., Tanneberger F. and Moen A. (eds.), Mires and peatlands of Europe: Status, distribution, and nature conservation.

Schweizerbart Science Publishers. Stuttgart.

Ilomets M., Animägi J. \& Kallas R. (1995). Estonian Peatlands. A brief review of their development, state, conservation, peat resources and management. Tallinn, $48 \mathrm{p}$.

Ilomets M., Pajula R., Sepp K. \& Truus L. (2010). Soometsade inventuur (soometsad väljaspool kaitsealasid). Tallinn (manuscript).

${ }^{14}$ http://www.ramsar.org/sites/default/files/documents/pdf/cop11/res/cop11-res08-e-anx1.pdf; https://rsis.ramsar.org/about 
Ingerpuu N., Kalda A., Kannukene L., Krall H., Leis M. \& Vellak K. (1994). List of Estonian Bryophytes. Abiks Loodusevaatlejale 94: 1-176.

Joosten H. (2009). The Global Peatland $\mathrm{CO}_{2}$ Picture. Peatland status and drainage associated emissions in all countries of the World. Wetlands International, Ede, 10 p. + tables.

Joosten H. \& Clarke D. (2002). Wise use of mires and peatlands - Background and principles including a framework for decision-maker. Saarijärven Offset Oy, Saarijärvi, Finland, $304 \mathrm{p}$.

Kannuke L. \& Kask M. (1982). A preliminary list of Bryophytes of Estonian peatlands. In: Masing V. (ed.), Peatland Ecosystems. Valgus, Tallinn, pp. 34-38.

Kask M. (1982). A list of vascular plants of Estonian peatlands. In: Masing V. (ed.), Peatland Ecosystems. Valgus, Tallinn, pp. 39-49.

Laasimer L. (1965). Eesti NSV taimkate. Valgus, Tallinn.

Masing V. (1975). Mire typology of the Estonian S.S.R. In: Laasimer L. (ed.), Some aspects of botanical research in the Estonian S.S.R. Valgus, Tartu, pp. 123-138 (in Estonian).

Masing V. (1988). Soode maastikuline liigitus. In: Valk U., Eesti sood. Valgus, Tallinn, pp. 69-76 (in Estonian).

Minayeva T., Sirin A. \& Bragg O. (eds.) (2009). A Quick Scan of peatlands in Central and Eastern Europe. Wetlands International, Wageningen, The Netherlands, 132 p., 6 Tables, 17 Figures.

NIS Estonia (2014). National Inventory Submission of Estonia. GHG Emissions in Estonia 1990-2012, Submission to the UNFCCC secretariat, Tallin, 443 p. + Annexes.

NIS Iceland (2014). National Inventory Submission of Iceland. Emissions of greenhouse gases in Iceland from 1990 to 2012. Submitted under the United Nations Framework Convention on Climate Change and the Kyoto Protokoll, Environment Agency of Iceland, 270 p. + Annexes.

Paal J. \& Leibak E. (2011). Estonian Mires: Inventory of Habitats. Eestimaa Looduse Fond, Tartu, 174 p.+ XXXV plates +11 p of photos.

Raukas A. \& Kajak K. (1997). Quaternary cover. In: Raukas A. \& Teedumäe A. (eds.), Geology and mineral resources of Estonia. Estonian Academic Publishers, Tallinn, pp. 125-136.

Remm L. (2015). Impacts of forest drainage on biodiversity and habitat quality: implications for sustainable management and conservation. Dissertationes Biologicae Universitates Tartuensis 269, University of Tartu Press, Tartu, Estonia, 126 p.

Valk U. (1988). Utilization of peatlands in Estonia: a historical review. Proc. 8th Int. Peat Congress, Sect. 1, Leningrad, pp. 78-82.

Vasander H., Tuittila E.-S., Lode E.,Ludin L., Ilomets M., Sallantaus T., Heikkilä R., Pitkänen M.-L. \& Laine J. (2003). Status and restoration of peatlands in northern Europe. Wetlands Ecology and Management 11: 51-63. http://dx.doi.org/10.1023/ A:1022061622602 


\subsection{Latvia}

\subsubsection{Characterization of the country}

Figure 1: NorBalWet countries covered in this report (grey); Latvia (dark grey)

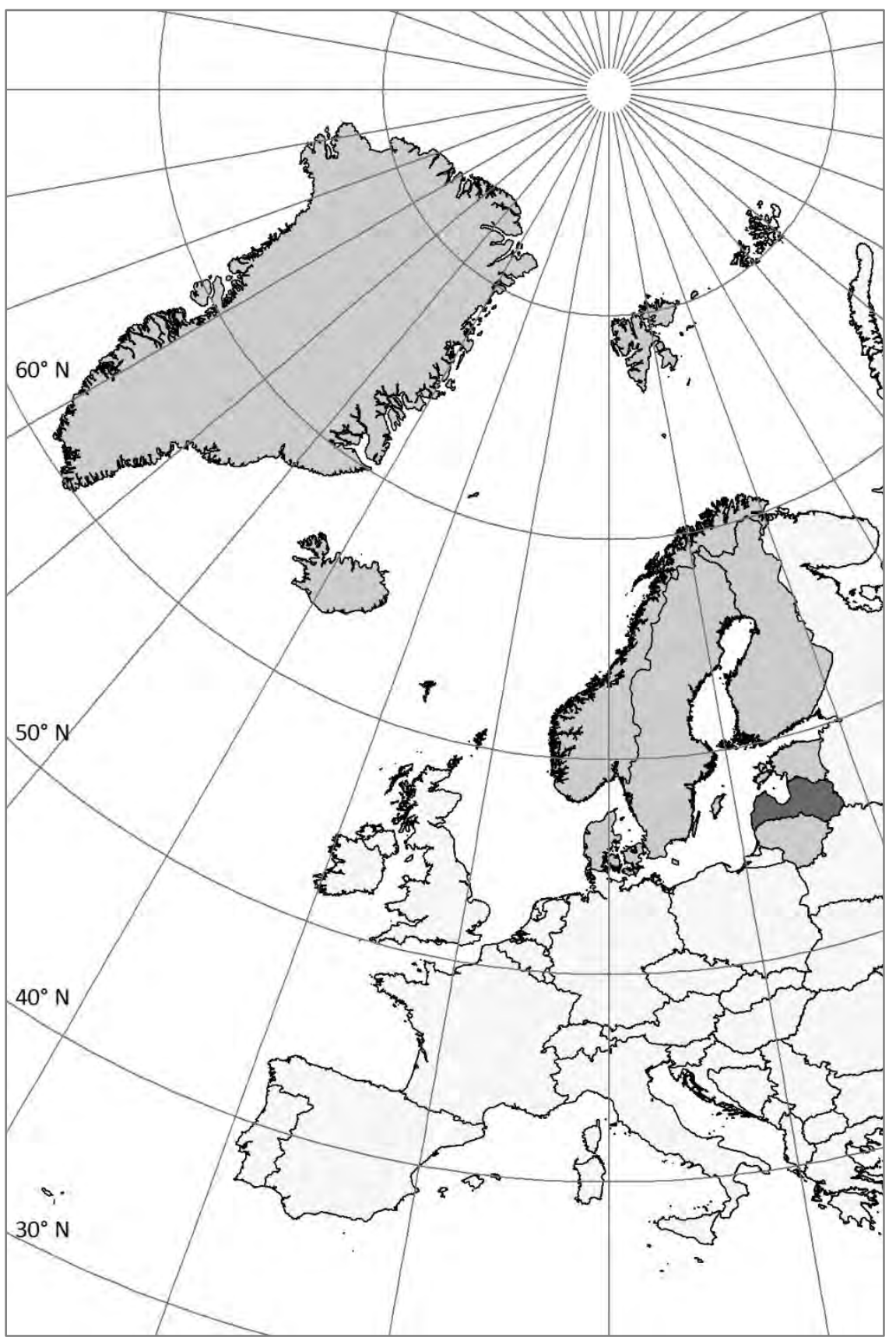


The Republic of Latvia is located at the East coast of the Baltic Sea, between $55^{\circ} 40^{\prime}$ and $58^{\circ} 05^{\prime} \mathrm{N}$ and $20^{\circ} 58^{\prime}$ and $28^{\circ} 14^{\prime} \mathrm{E}$ (Figure 1). Geologically, Latvia lies in the western part of the East-European plain. Sandstone, dolomite, limestone, and gypsum form the upper layer of sedimentary rocks. The influence of these rocks regarding natural habitats depends on the thickness of Quaternary deposits, which varies from 310 m to only $1 \mathrm{~m}$ (Pakalne \& Aleksāns 2015). Major changes in the surface geomorphology took place during the last glacial period. The character of the coastal areas was, more recently, shaped by transgression and regression of the Baltic Sea. The climate is mild and dominated by marine air masses in the West; towards the East it becomes more continental. The mean annual precipitation is $500-800 \mathrm{~mm}$. The mean January temperature varies from $-2.6{ }^{\circ} \mathrm{C}$ to $-6.6{ }^{\circ} \mathrm{C}$; the mean July temperature from $+16.8^{\circ} \mathrm{C}$ to $+17.6{ }^{\circ} \mathrm{C}$ (Pakalne \& Aleksāns 2015).

\subsubsection{Peatland diversity}

The classification of undisturbed peatlands (mires) in Latvia follows the widely used division into three main categories: fens, transition mires, and raised bogs (Pakalne \& Aleksāns 2015). Fens occur widely in Latvia wherever groundwater logged conditions prevail. They range from extensive complexes to small sites of a few square metres in association with springs (Pakalne \& Aleksāns 2015). Calcareous fens occur near coastal lagoon lakes over limestone substrate and are, as spring fens, extremely rich in species. Poor fens prevail in areas with non-calcareous ground water (Pakalne \& Aleksāns 2015). Raised bogs are located throughout Latvia. They are dome-shaped or plateau-like, concentric or eccentric (Pakalne \& Aleksāns 2015). The central part of the bogs is often open and the margins are wooded. The most common micro-relief feature of raised bogs is the alternation of drier hummocks and ridges with wetter hollows and open-water pools. The vegetation of ombrotrophic bogs has a significant cover of dwarf ericoid shrubs and a dominance of Sphagnum species in the moss layer that distinguish them from other mire types (Pakalne \& Aleksāns 2015). Two regional raised bog types can be distinguished according to their dominant plant species: the western type with Trichophorum cespitosum and the eastern type with Chamaedaphne calyculata (Pakalne \& Aleksāns 2015). 


\subsubsection{Peatland degradation}

Drainage of peatlands started in Latvia in the 17th century; in the 18th century peat was widely used as fuel and in agriculture. Today, Latvian peatlands are used for agriculture, forestry, and peat extraction. The most intensive drainage projects were conducted between 1960 and 1980; today new drainage of bogs and fens has almost ceased. About $1,600 \times 10^{3}$ ha land was drained for agriculture and $500 \times 10^{3}$ ha for forestry (mineral and organic soil). Currently, a huge effort is undertaken to maintain the drainage system, which includes $120,000 \mathrm{~km}$ of ditches and channels, 950,000 km of drainpipes, and 50 polder pump stations. ${ }^{15}$ Peat extraction dates back to the end of the 18th century and was intensified after establishment of the state of Latvia in 1918 (Kirstuka 2004). 290,000 tons peat were extracted in 1940; during the years of the Soviet rule peat extraction reached its maximum with 7.3 million tons in 1965. Peat was extracted for energy and agricultural purposes from more than 100 fields. At the end of the 1980s the annual extracted peat volume exceeded 2.5 million tons (Kirstuka 2004). After 1991, when Latvia obtained independence, peat extraction diminished to 0.5 million tons in 1993. During the last 15 years total peat extraction often exceeds 0.7 million tons per year; in 2013 it reached approximately 1.0 million tons. ${ }^{16}$

The "5th National report to the Convention on Biological Diversity of Latvia" (2014) ${ }^{17}$ "reveals that 50 protected plant species occur in Latvian peatlands (43 in fens, 15 in raised bogs and 27 in transitional mires). This mainly includes orchids (15 species) and sedges (10 species).In terms of biodiversity, fens are the most threatened of all peatland types due to their extensive and persisting drainage and continuous use for forestry and agriculture, especially those located in the large floodplains (Pakalne \& Aleksāns 2015). Furthermore, over the last decades the bird species related to mires have the largest decline in terms of biodiversity. Threats to biodiversity include peat extraction, overgrowing of peatlands due to melioration, and more in general the low environmental awareness of the public and politicians (Pakalne \& Aleksāns 2015).

\footnotetext{
${ }^{15} \mathrm{http}: / /$ www.emps.ee/uus/sites/default/files/Latvian\%20drainage\%20plans\%20for\%202020E.Grikitis_0.pdf

16 http://www.asocdurpes.lt/forum2013/downloads/I.\%200ZOLA_Peat\%20production\%20in\%202013 Latvia_05\%2009\%202013-EN.pdf

${ }^{17}$ Available at: http://www.cbd.int/doc/world/lv/lv-nr-05-en.pdf
} 


\subsubsection{Current peatland: location, extent, status, land use and greenhouse gas emissions}

\section{Material and Methods}

To assess the location and extent of peatlands we used

- the GIS polygon vector data of Latvian "purvi" ("swamps" - covering peat deposits; scale 1:500,000) provided by SIA ENVIROTECH within the GISLatvia- geodatabase, available at: http://gis.sub.lv/lv/gispakalpojumi/. These data were already classified into the peatland types: raised bogs (augstais), transition mires (pārejas) and fens (zemais). We adopted this classification unchanged. This dataset does not contain information on the drainage status of the peatlands.

To estimate the extent of peatlands drained for forestry, agriculture and peat extraction geospatially explicit, GIS data on drainage system and land use are needed. These data might be available at the Latvian Geospatial Information Agency, ${ }^{18}$ but not freely available. Therefore we used the freely available land use layer of:

- the Polygon vector data of Latvian "mezi" (covering forested areas; scale 1:500,000) provided by SIA ENVIROTECH within the GISLatviageodatabase (http://gis.sub.lv/lv/aktualitates/gis-latvija-10-2/). This dataset does not contain information on the drainage status of forested sites. We assumed all forested peatlands to be drained.

- the Polygon vector data of peat extraction sites digitized and provided by Agnese Priede from the Laboratory of Geobotany at the Institute of Biology (University of Latvia), which is based on aerial photos of 2007 (Norakti_purvi_LV_2007.shp).

18 http://www.lgia.gov.lv/en/Par\%20mums.aspx 
Table 1: GIS overlay analysis of the peatland dataset of Latvian "purvi" with the land use datasets on forest (mezi) and peat extraction (Norakti_purvi_LV_2007.shp), and resulting land use types. Land use types do not correspond to UNFCCC/IPCC land use categories

\begin{tabular}{|c|c|c|c|c|c|c|}
\hline \multirow[t]{2}{*}{ Land use types } & \multicolumn{4}{|c|}{ Peatland dataset $^{19}$} & \multicolumn{2}{|c|}{ Land use datasets } \\
\hline & Bog & $\begin{array}{l}\text { Transition } \\
\text { mire }\end{array}$ & Fen & $\begin{array}{c}\text { Other } \\
\text { peatland }\end{array}$ & Forest $^{20}$ & $\begin{array}{c}\text { Peat } \\
\text { extraction }^{21}\end{array}$ \\
\hline Unclear drainage, open ${ }^{11}$ & $\mathrm{x}$ & $\mathrm{x}$ & $\mathrm{x}$ & & & \\
\hline Drained forested ${ }^{2)}$ & $x$ & $x$ & $x$ & & $x$ & \\
\hline Drained peat extraction A & $\mathrm{x}$ & $\mathrm{x}$ & $\mathrm{x}$ & & & $\mathrm{x}$ \\
\hline Drained peat extraction $\mathrm{B}^{3)}$ & & & & $x$ & & $x$ \\
\hline
\end{tabular}

${ }^{1)}$ All peatland areas that are not covered by land use dataset , forest", or "peat extraction".

${ }^{2)}$ All peatland areas that are covered by the land use unit "forest" are considered to be drained.

${ }^{3)}$ These are parts of peat extraction sites that lay outside of the area covered by peatland dataset Latvian "purvi". Subsequently, all peat extraction areas are summed up in one land use type (see Table 4).

For error analysis of the GIS dataset Latvian "purvi", we visually checked the accuracy of the borders against open layer satellite images of Google Earth, Bing Aerial and OpenCycleMap - OCM (http://www.opencyclemap.org), and a digital elevation model (Jarvis et al. 2008) for five randomly selected areas with a diameter of $10 \mathrm{~km}$. This analysis showed that the peatland polygons in the GIS dataset of Latvian "purvi" seem to be regularly incorrect and the total coverage incomplete. Based on this, we assume that the results of our GIS overlay study considerably underestimate the extent of bogs, fens and transitional peatlands.

To bypass these, we additionally considered the land use area data on drained organic soils from

- the recent National Inventory Submission of Latvia to the United Nations Framework Convention on Climate Change (UNFCCC; NIS ${ }^{22}$ Latvia 2014). ${ }^{23}$

\footnotetext{
19 Original dataset name: "purvi_poly"

20 Original dataset name: mezi_poly'

21 Original dataset name: "Norakti_purvi_LV_2007.shp"

22 The National Inventory Submission ("NIS") consists of the National Inventory Report ("NIR") and the Common Reporting Format ("CRF"). Since both the NIR and the CRF were used, we further refer to the complete National Inventory Submission of Latvia (NIS Latvia 2014).

$23 \mathrm{https}$ //unfccc.int/national_reports/annex_i_ghg_inventories/national_inventories_submissions/items/ 8108.php
} 
The National Inventory Submission for Latvia (NIS Latvia 2014) reports land use on drained organic soil based to the National Forest Inventory (NFI). The NFI uses a permanent $4 \times 4 \mathrm{~km}$ grid across Latvia with four permanent sample plots of $500 \mathrm{~m}^{2}$ at each grid point (in total 16,383 sample plots).The NFI considers soils to be organic if the organic layer is at least $30 \mathrm{~cm}$ deep (NIS Latvia 2014).

Since the area estimates for Cropland and Grassland in NIS Latvia (2014) derive from extrapolation of historical maps and the real extent is "unknown" (NIS Latvia 2014), we additionally considered:

- area data on drained organic soils for Cropland and Grassland from the Statistics Division of the Food and Agriculture Organization of the United Nations (FAOStat). ${ }^{24}$

According to FAOStat the area of drained organic soils under Cropland is with $282.7 \times 10^{3}$ ha considerably larger than the $89.7 \times 10^{3}$ ha in NIS Latvia (2014).The estimate for drained organic soil under Grassland is nearly the same in FAOStat and NIS Latvia (2014; Table 5).

For addressing the area of undrained peatlands we additionally considered:

- Aunina (2013), which states that "mires" currently cover $4.9 \%$ of the area of Latvia. This would correspond to $316.7 \times 10^{3}$ ha (taking a total area of Latvia of $\left.6,458.9 \times 10^{3} \mathrm{ha}\right) .{ }^{25}$

For calculating the emissions from land use on drained peatlands for areas resulting from our GIS overlay analysis (Table 1, 3 and 4), we applied an emission factor of $9.5 \mathrm{t} \mathrm{CO}_{2} / \mathrm{ha} / \mathrm{yr}$ for drained, forested peatlands and of $10.3 \mathrm{t} \mathrm{CO}_{2} / \mathrm{ha} / \mathrm{yr}$ for drained peat extraction, respectively (Table 4). Other land use types could not be differentiated due to insufficient land use data (see above).

For emission calculation the NIS Latvia (2014) uses default emission factors for $\mathrm{CO}_{2}$ for drained organic soils from IPCC (2003; Tier 1) for Forest Land and Peat extraction. Since these emission factors are out-

\footnotetext{
${ }^{24}$ http://faostat3.fao.org/faostat-gateway/go/to/download/G1/GV/Methodology at: http://faostat3.fao.org/ faostat-download-js/PDF/EN/GV.pdf

25 http://en.wikipedia.org/wiki/Latvia
} 
dated, we recalculated the emissions using the new Tier 1 emission factors of IPCC (2014) (Table 2, 5). Because Latvia belongs to the Temperate climate/vegetation zone according to IPCC, ${ }^{26}$ we did not apply the Tier 2 emission factors from Sweden for Cropland and Grassland as done in NIS Latvia (2014; cf. Table 2).

Table 2 shows the emission factors for $\mathrm{CO}_{2}$ for drained organic soils as applied in NIS Latvia (2014) and the Tier 1 emission factors from IPCC (2014), respectively, which are applied on the area estimates of NIS Latvia (2014, Table 5) and FAOStat (Table 6).

\begin{tabular}{|c|c|c|}
\hline \multirow[t]{2}{*}{ IPCC category } & \multicolumn{2}{|c|}{ Emission factors for $\mathrm{CO}_{2}$ in $\mathrm{t} \mathrm{CO}_{2} / \mathrm{ha} / \mathrm{yr}$} \\
\hline & NIS Latvia (2014) & IPCC (2014) \\
\hline Forest Land remaining Forest Land & 2.5 & 9.5 \\
\hline Cropland & & 29.0 \\
\hline Cropland remaining Cropland & 13.6 & \\
\hline Forest Land converted to Cropland & 30.1 & \\
\hline Grassland & & 20.9 \\
\hline Grassland remaining Grassland & 5.9 & \\
\hline Cropland converted to Grassland & 8.4 & \\
\hline Peat extraction & 0.7 & 10.3 \\
\hline
\end{tabular}

The emission factors used in NIS Latvia (2014) are considerable lower than the IPCC (2014) default emission factor for $\mathrm{CO}_{2}$ for the Temperate climate/vegetation zone (except for Forest Land converted to Cropland, Table 2). This emission recalculation resulted in approximately three times higher annual emissions (see Table 5).

To address utilization pressure and threat of peatland types and mire habitats in Lithuania, we used:

- the "5th National report to the Convention on Biological Diversity (CBD ${ }^{27}$ ) of Latvia" (2014).28

Carbon loss from DOC (Dissolved Organic Carbon) is not included in this study.

Peat carbon stocks were derived from the Ministry of Environment of the Republic of Latvia (2004).

\footnotetext{
${ }^{26}$ See http://eusoils.jrc.ec.europa.eu/projects/RenewableEnergy/

${ }^{27}$ http://www.cbd.int/

${ }^{28}$ Available at: http://www.cbd.int/doc/world/lv/lv-nr-05-en.pdf
} 


\section{Results}

Our GIS analysis shows that Latvian peatlands cover in total $599.1 \times 10^{3}$ ha, including $253.1 \times 10^{3}$ ha of bog, $57.5 \times 10^{3}$ ha of transition mires, $283.3 \times 10^{3}$ ha of fen, and $5.2 \times 10^{3}$ ha of other peatland (Table 3). The largest concentrations occur in southeast and northeast Latvia (around Valmiera). Some large areas also are situated south and west of Riga (Figure 2).

\begin{tabular}{|c|c|c|c|c|c|c|}
\hline \multirow[t]{2}{*}{ Peatland type } & \multirow{2}{*}{$\begin{array}{l}\text { Area } \\
10^{3} \text { ha }\end{array}$} & \multicolumn{2}{|c|}{ Drained area } & \multicolumn{2}{|c|}{ Unknown drainage } & \multirow{2}{*}{$\begin{array}{l}\text { Emissions } \\
\mathrm{Mt} \mathrm{CO} / \mathrm{yr}\end{array}$} \\
\hline & & $10^{3}$ ha & $\%$ & $10^{3}$ ha & $\%$ & \\
\hline Bog & 253.1 & 161.3 & 63.7 & 91.9 & 36.3 & 1.55 \\
\hline Transition mire & 57.5 & 45.6 & 79.2 & 11.9 & 20.8 & 0.43 \\
\hline Fen & 283.3 & 165.4 & 58.4 & 117.8 & 41.6 & 1.58 \\
\hline Other peatland ${ }^{1)}$ & 5.2 & 5.2 & 100.0 & 0.0 & 0.0 & 0.05 \\
\hline$\sum$ total & 599.1 & 377.5 & 63.0 & 221.6 & 37.0 & $3.61^{29}$ \\
\hline
\end{tabular}

1) These are parts of peat extraction sites, which are not covered by the peatland GIS data of Latvian "purvi".

${ }^{29}$ Considerably underestimated, since emissions from agriculture could not be assessed (GIS data were not available). More reliable data: from NIS Latvia and other available sources (Table 5). 
Table 4: Extent of drained Bog, Transition Mire, Fen and Other Peatland in Latvia and associated soil $\mathrm{CO}_{2}$ emissions (based on the dataset of Latvian "purvi"). Emission factors for $\mathrm{CO}_{2}$ are the IPCC (2014) default values for the Temperate climate/vegetation zone

\begin{tabular}{|c|c|c|c|}
\hline Peatland and land use type & $\begin{array}{r}\text { Area } \\
\left(10^{3} \mathrm{ha}\right)\end{array}$ & $\begin{array}{l}\text { Emission factor } \\
\text { (t CO } / \mathrm{ha} / \mathrm{yr} \text { ) }\end{array}$ & $\begin{array}{r}\text { Emissions } \\
(\mathrm{Mt} \mathrm{CO} / \mathrm{yr})\end{array}$ \\
\hline \multicolumn{4}{|l|}{ Bog } \\
\hline drainage unknown, open & 91.9 & ? & ? \\
\hline drained forested & 140.8 & 9.5 & 1.34 \\
\hline drained peat extraction & 20.4 & 10.3 & 0.21 \\
\hline$\sum$ subtotal & 253.1 & & 1.55 \\
\hline \multicolumn{4}{|l|}{ Transition mire } \\
\hline drainage unknown, open & 11.9 & ? & ? \\
\hline drained forested & 43.4 & 9.5 & 0.41 \\
\hline drained peat extraction & 2.2 & 10.3 & 0.02 \\
\hline$\sum$ subtotal & 57.5 & & 0.43 \\
\hline \multicolumn{4}{|l|}{ Fen } \\
\hline drainage unknown, open & 117.8 & ? & ? \\
\hline drained forested & 155.9 & 9.5 & 1.48 \\
\hline drained peat extraction & 9.6 & 10.3 & 0.10 \\
\hline \multirow[t]{2}{*}{$\sum$ subtotal } & 283.3 & & 1.58 \\
\hline & & & 1,58 \\
\hline \multicolumn{4}{|l|}{ Other peatland ${ }^{30}$} \\
\hline drained peat extraction & 5.2 & 10.3 & 0.05 \\
\hline ¿subtotal & 5.2 & & 0.05 \\
\hline \multirow[t]{2}{*}{$\Sigma$ total } & $599.1^{31}$ & & $3.61^{32}$ \\
\hline & & & 3.61 \\
\hline
\end{tabular}

30 These are parts of peat extraction sites that are not covered by the peatland dataset of Latvian "purvi".

31 This figure considerably underestimates the extent of drained peatlands. Incomplete land use data hampered the assessment of areas drained for agriculture. Other data are presented in Table 5, 6 .

32 This figure considerably underestimates the emissions from drained peatlands in Latvia, due to insufficient GIS data on extent and land use. 
Figure 2: Location and extent of peatland types in Latvia (based on the peatland dataset Latvian "purvi"). "Other peatland" covers peat extraction sites that lay outside of the peatland dataset (see Table 1)

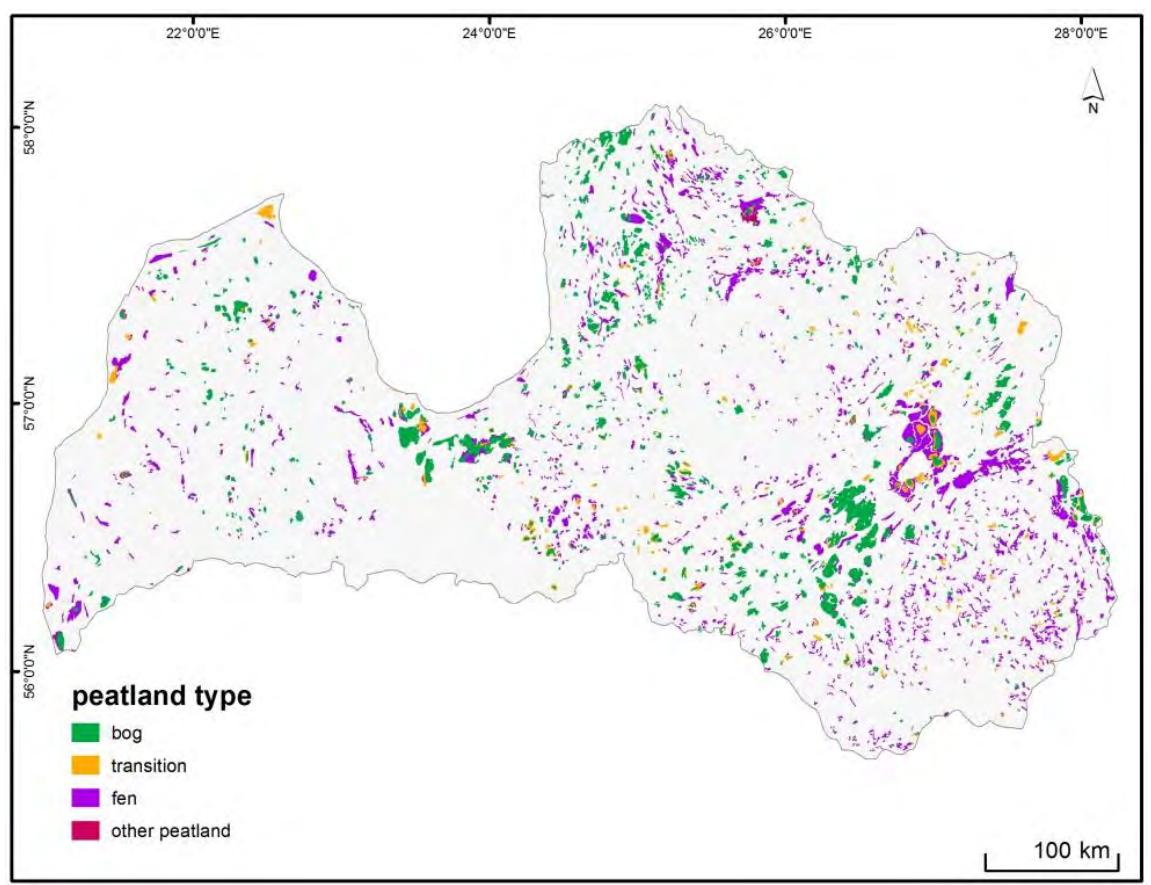

Figure 3: Land use types and drainage status of peatlands in Latvia (GIS overlay analysis; see Table 1). Land use types do not correspond to the UNFCCC/IPCC land use categories

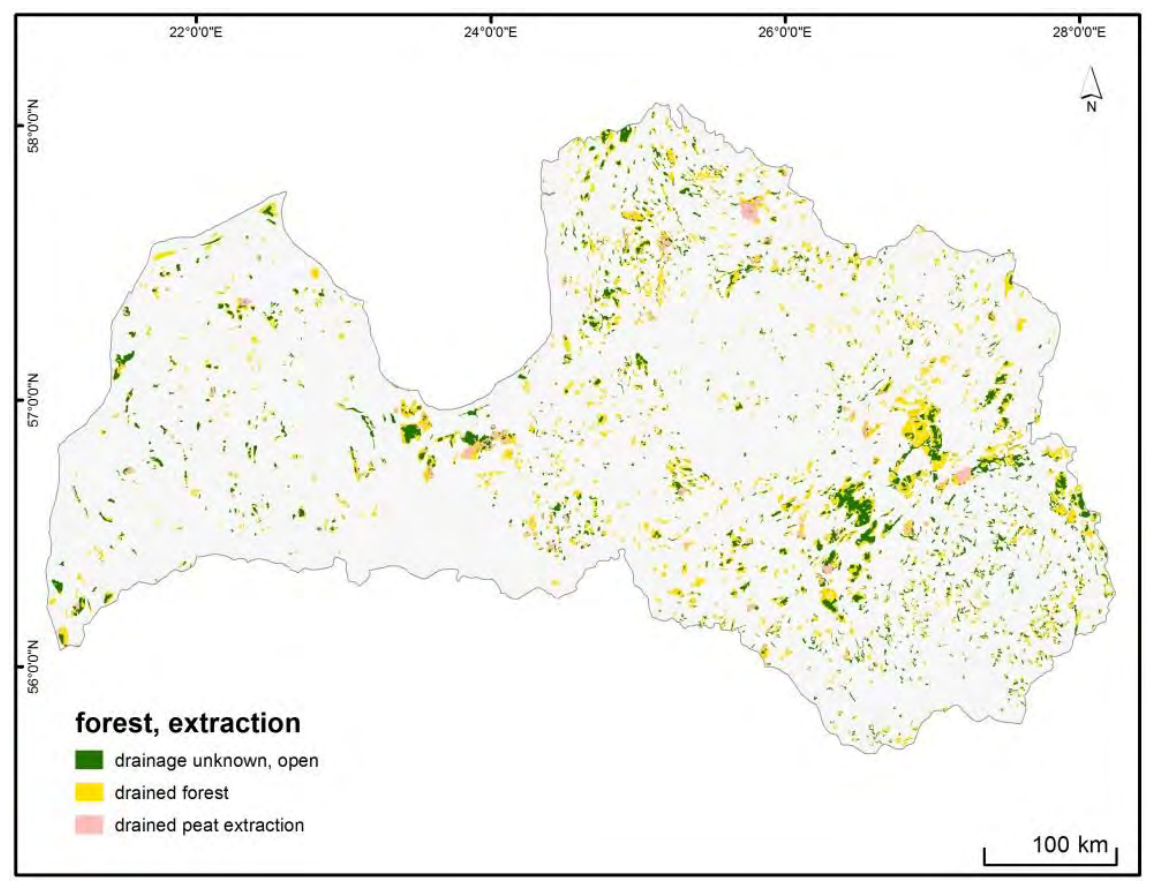


In its NIS (2014) Latvia reported $433.7 \times 10^{3}$ ha of Forest Land on drained organic soil, $89.7 \times 10^{3}$ ha Cropland on drained organic soil, 36.7 $\times 10^{3}$ ha of Grassland on drained organic soil, and $27 \times 10^{3}$ ha of organic soil drained for Peat extraction (Table 5). Drainage and use of these areas lead, according to the NIS Latvia (2014), to an annual $\mathrm{CO}_{2}$ emission of $2.6 \mathrm{Mt}$. Using the latest IPCC (2014) default emission factors for $\mathrm{CO}_{2}$ and for the Temperate climate/vegetation zone, these emissions increase to annually $7.8 \mathrm{Mt} \mathrm{CO}_{2}$ (Table 5). Moreover, the State Company "Agriculture Ministry Real Estate" estimates the total extent of land drained for agriculture at $1,600 \times 10^{3}$ ha (but this also includes mineral soils). ${ }^{33}$

The GIS dataset of peat extraction sites ("Norakti_purvi_LV_2007.shp", see Material and Methods above), which is based on aerial photos from 2007 , lead to an area of $37.4 \times 10^{3}$ ha, which is more than reported in NIS Latvia (2014; Table 5). However, based on aerial photos we estimate that approximately $25 \%$ of the current peat extraction areas are still not covered in this GIS dataset. Thus, we recalculated the extent of peat extraction sites to $46.6 \times 10^{3}$ ha (Table 6). If we consider the latter figure and the FAOstat data for Cropland and Grassland on drained organic soils to be realistic, the total area of drained organic soils would be $797.8 \times 10^{3}$ ha with annual $\mathrm{CO}_{2}$ emissions of $13.5 \mathrm{Mt}$ (Table 6).

33 http://www.emps.ee/uus/sites/default/files/Latvian\%20drainage $\% 20$ plans $\% 20$ for $\% 202020$ - 
Table 5: Drained organic soil areas, land use types and associated $\mathrm{CO}_{2}$ emissions. Left part of the table: as reported in the National Inventory Submission of Latvia (2014) to the UNFCCC. Right part: recalculation of emissions with the new IPCC (2014) default emission factors for $\mathrm{CO}_{2}$ for the Temperate climate/vegetation zone

\begin{tabular}{|c|c|c|c|c|c|c|}
\hline \multirow[t]{2}{*}{ Latvi } & \multicolumn{4}{|c|}{$\begin{array}{l}\text { National Inventory } \\
\text { Submission } 2014\end{array}$} & \multicolumn{2}{|c|}{$\begin{array}{l}\text { Recalculated according to IPCC } \\
2014\end{array}$} \\
\hline & $\begin{array}{r}\text { Area of } \\
\text { organic } \\
\text { soil } \\
\left(10^{3} \mathrm{ha}\right)\end{array}$ & $\begin{array}{r}\text { Net carbon } \\
\text { stock change } \\
\text { per area } \\
\left(\mathrm{t} \mathrm{CO}_{2} / \mathrm{ha} / \mathrm{yr}\right)\end{array}$ & $\begin{array}{r}\text { Emissions } \\
(\mathrm{Mt} \mathrm{CO} / \mathrm{yr})\end{array}$ & $\begin{array}{r}\text { EF } \\
\text { TIER }\end{array}$ & $\begin{array}{r}\text { Net carbon } \\
\text { stock change } \\
\text { per area } \\
(\mathrm{t} \mathrm{CO} / \mathrm{ha} / \mathrm{yr})\end{array}$ & $\begin{array}{r}\text { Emissions } \\
(\mathrm{Mt} \mathrm{CO} / \mathrm{yr})\end{array}$ \\
\hline Land Use Category & & & & & & \\
\hline $\begin{array}{l}\text { Forest Land remaining } \\
\text { Forest Land }\end{array}$ & 428.9 & 2.5 & 1.07 & 1 & 9.5 & 4.07 \\
\hline $\begin{array}{l}\text { Grassland converted } \\
\text { to Forest Land }\end{array}$ & 4.8 & 2.5 & 0.01 & & 9.5 & 0.05 \\
\hline$\sum$ Forest Land & 433.7 & & 1.08 & & & 4.13 \\
\hline $\begin{array}{l}\text { Cropland remaining } \\
\text { Cropland }\end{array}$ & 87.5 & 13.6 & 1.19 & 2 & 29.0 & 2.54 \\
\hline $\begin{array}{l}\text { Forest Land converted } \\
\text { to Cropland }\end{array}$ & 2.2 & 30.1 & 0.07 & & 29.0 & 0.06 \\
\hline$\sum$ Cropland $^{1)}$ & 89.7 & & 1.26 & & & 2.60 \\
\hline $\begin{array}{l}\text { Grassland remaining } \\
\text { Grassland }\end{array}$ & 28.7 & 5.9 & 0.17 & 2 & 20.9 & 0.60 \\
\hline $\begin{array}{l}\text { Cropland converted } \\
\text { to Grassland }\end{array}$ & 8.0 & 8.4 & 0.07 & & 20.9 & 0.17 \\
\hline$\sum$ Grassland $^{1)}$ & 36.7 & & 0.24 & & & 0.77 \\
\hline $\begin{array}{l}\text { Wetlands remaining } \\
\text { Wetlands }\end{array}$ & & & 0.00 & & & 0.00 \\
\hline Peat extraction & 27.0 & 0.7 & 0.02 & 1 & 10.3 & 0.28 \\
\hline$\Sigma$ Wetlands & 27.0 & & 0.02 & & & 0.28 \\
\hline$\sum$ Totall & 587.0 & & 2.59 & & & 7.78 \\
\hline
\end{tabular}

1). The area estimates for Cropland and Grassland derive from extrapolation of historical maps and the real current extent of both is "unknown" (NIS Latvia 2014). 
Table 6: Area of peatlands and organic soils in Latvia: (A) according to different sources, (B) estimated total peatland area and related $\mathrm{CO}_{2}$ emissions (left columns), which derive from combinations of area data from (A) and the application of the IPCC (2014) emission factors for $\mathrm{CO}_{2}$ for the Temperate climate/vegetation zone. Land use types only fully correspond to the UNFCCC/IPCC land use categories with respect to data from NIS Latvia (2014)

\begin{tabular}{|c|c|c|c|c|c|c|c|}
\hline \multirow[t]{3}{*}{$\begin{array}{l}\text { Drainage status and land use } \\
\text { types }\end{array}$} & \multicolumn{3}{|c|}{ A) Available area and land use data } & \multicolumn{4}{|c|}{$\begin{array}{l}\text { B) Total organic soil area (combinations of available data in } \\
\text { left part of the table) and related emissions }\end{array}$} \\
\hline & \multirow{2}{*}{$\begin{array}{l}\text { NIS Latvia } \\
(2014)^{1)} \\
\left(10^{3} \text { ha }\right)\end{array}$} & \multirow{2}{*}{$\begin{array}{r}\text { FAO- } \\
\text { STAT }^{2)} \\
\left(10^{3} \mathrm{ha}\right)\end{array}$} & \multirow{2}{*}{$\begin{array}{l}\text { Other } \\
\left(10^{3} \mathrm{ha}\right)\end{array}$} & \multicolumn{2}{|c|}{$\begin{array}{l}\text { NIS Latvia (2014) + } \\
\text { undrained peatland }\end{array}$} & \multicolumn{2}{|c|}{$\begin{array}{l}\text { NIS Latvia (2014) + undrained } \\
\text { peatland + FAOSTAT }\end{array}$} \\
\hline & & & & (10 ha) & $(\mathrm{Mt} \mathrm{CO} / \mathrm{yr})$ & (10 ha) & $(\mathrm{Mt} \mathrm{CO} / \mathrm{yr})$ \\
\hline Total peatland & & & $\begin{array}{l}599.1^{3)} \\
645.9^{4)}\end{array}$ & & & & \\
\hline Undrained peatland & & & $316.5^{5)}$ & 316.5 & \pm 0 & 316.5 & \pm 0 \\
\hline Total organic soil, forest land & 703.9 & & & & & & \\
\hline "Wet" organic soil, forest land & $270.2^{6)}$ & & & & & & \\
\hline $\begin{array}{l}\text { Drained organic soil, forest } \\
\text { land }\end{array}$ & 433.7 & & & 433.7 & 4.13 & 433.7 & 4.13 \\
\hline Drained organic soil, cropland & 89.7 & 282.7 & & 89.7 & 2.60 & 282.7 & 8.19 \\
\hline Drained organic soil, grassland & 36.7 & 34.8 & & 36.7 & 0.77 & 34.8 & 0.73 \\
\hline Drained peat extraction & 27.0 & & $46.6^{7,8)}$ & 27.0 & 0.28 & 46.6 & 0.48 \\
\hline $\begin{array}{l}\sum \text { Subtotal drained organic soil } \\
\text { area and related emissions }\end{array}$ & & & & & & 797.8 & 13.53 \\
\hline$\sum$ Total organic soil area & & & & 903.6 & 7.78 & $1,114.3$ & \\
\hline
\end{tabular}

1) National Inventory Submission on GHG emissions to the UNFCCC 2014 (NIS Latvia 2014).

${ }^{2)}$ http://faostat.fao.org/site/739/DesktopDefault.aspx?PagelD=739\#ancor.

3) Our GIS overlay analysis, considerably underestimated (see Material and Methods above

4) " $10.4 \%$ of the area of Latvias is covered by peat deposits with a peat layer of $>30 \mathrm{~cm}$ and a size of

$>1$ ha (cf. http://www.cbd.int/doc/world/lv/lv-nr-05-en.pdf).

5) After Aunina (2013) the current "mire" area covers $4.9 \%$ of Latvia. With a total area of Latvia of $6,458.9 \times 10^{3} \mathrm{ha}^{34}$ this results in a mire (=undrained peatland) area of $316.5 \times 10^{3}$ ha.

${ }^{6)}$ It is is unclear whether these "wet" organic soils are included in the "mire" area of Anunina (2013).

7) Estimate derived from this study, using the dataset on peat extraction sites digitized and provided by Agnese Priede (University of Latvia; “Norakti_purvi_LV_2007.shp”; see Material and Methods above).

${ }^{8)}$ The area of peatland influenced by peat extraction might also be $70.0 \times 10^{3}$ ha (Pakalne \& Aleksāns 2015).

${ }^{34}$ http://en.wikipedia.org/wiki/Latvia 


\section{Discussion}

Our literature and GIS study resulted in various figures on the extent of peatlands and organic soils in Latvia and their land use and drainage status. Unfortunately the figures are often conflicting. This may result from the use of different definitions and methods in various studies and from incomplete GIS datasets. The "5th National report to the Convention on Biological Diversity of Latvia" (2014), for example, mentions that peatlands (with $>30 \mathrm{~cm}$ of peat layer and $>1 \mathrm{ha}$ ) cover $10.4 \%$ of the territory of Latvia, which would correspond to $645.9 \times 10^{3}$ ha. The National Inventory Submission for Latvia to the UNFCCC (NIS Latvia 2014), in contrast, reports the Forest Land on organic soils ${ }^{35}$ to cover $703.9 \mathrm{x}$ $10^{3}$ ha, 36 i.e. an area larger than the total peatland area reported in the former report.

The "5th National report to the Convention on Biological Diversity of Latvia" (2014) furthermore claims $70 \%$ of the bogs $^{37}$ of Latvia "to be relatively unaffected" and only 30\% drained. Similarly, the Investment and Development Agency of Latvia ${ }^{38}$ states that only $27.3 \%$ of the peatlands of Latvia are drained for agriculture, forestry and peat extraction, unfortunately both without mentioning the total peatland area. These figures do not match with the huge area of drained organic soils reported to the UNFCCC (NIS Latvia 2014, Table 5). However, satellite and aerial images still reveal a considerable area of undrained bogs in Latvia. After Aunina (2013), the extent of "mires" (=undrained peatlands) of Latvia is $316.5 \times 10^{3}$ ha ( $4.9 \%$ of the country area). Totalizing this area estimate and available figures for drained organic soils, the overall area of peatlands and organic soils in Latvia might be 1,114.3 x $10^{3}$ (Table 6). To harmonise the existing area data, the knowledge and data from peatland inventories could be combined with the outcomes of the National Forest Inventory, which compiles the area estimates of drained organic soils for the national reporting of Latvia to the UNFCCC. Additionally, the current mapping of the drainage system throughout Latvia opens perspectives for an accurate assessment of drainage in organic soils. ${ }^{39}$

It is obvious that peat extraction is a major and important industrial sector, which will keep a high utilization pressure on the bogs of Latvia.

\footnotetext{
35 In the NFI soils are considered organic if the organic layer is at least $30 \mathrm{~cm}$ deep (NIS Latvia 2014).

36 Organic soil has an organic layer $>30 \mathrm{~cm}$ (NIS Latvia 2014).

37 The term "bog" is sometimes used for "peatland", which creates confusion.

${ }^{38}$ Available at: http://www.liaa.gov.lv/files/liaa/attachments/k_2013_environment_and_renewable_energy_

industry_in_latvia.pdf

${ }^{39}$ Melioration cadastre; available at: http://www.melioracija.lv/
} 
The amount of extracted peat increased from 399,000 $t$ in the year 2000 to $1,100,000 \mathrm{t}$ in 2013 (on average 800,000 $\mathrm{t}$ annually). ${ }^{40}$ The "Latvian Peat Producers Association" aims to integrate peat in the National Energy Guidelines and targets to cover 5\% of the energy supply for Latvia with peat fuel in 2020 in order to implement "the transition of the economy, which creates low-carbon missions in all sectors." 41 It should be emphasised that peat combustion does not achieve low-carbon goals, since peat is a fossil fuel with a higher emission factor per unit of energy produced than other fossil fuels (IPCC 2006).

Currently and ongoing until 2020, the drainage infrastructure in Latvia will be modernized, ${ }^{42}$ to some extent motivated by annual rainfall abnormalities. This huge effort may, by chance, also restore drainage schemes in protected peatlands as is happening in some Natura 2000 sites (pers. comm. Agnese Priede 2014).

In conclusion, there seems to be an urgent need for a comprehensive assessment of Latvian peatlands, their extent, drainage status, biodiversity and general level of threat, ${ }^{43}$ as a valuable basis for preserving the diversity of the peatlands of Latvia, while developing a wise use strategy for them.

\subsubsection{Inventory, conservation and restoration of peatlands}

Restoration efforts for peatlands in Latvia are mainly targeted to Natura 2000 sites. Since all Ramsar sites of Latvia overlap with Natura 2000 sites, conservation and restoration for Natura 2000 sites can be also implemented under the framework of the Ramsar Convention. The future plans for restoring peatlands are defined in the "Priority Action Framework for Natura 2000" (2014-2020; PAF). PAF defines the problems involved with peatland utilization and conservation in a rather general way without identifying concrete sites or the overall extent of areas to be restored. The priorities defined in PAF include a country wide inventory of habitats and species, the restoration of bog, fen and

\footnotetext{
40 http://www.asocdurpes.lt/forum2013/downloads/I.\%200ZOLA_Peat\%20production\%20in\%202013_ Latvia_05\%2009\%202013-EN.pdf

41 http://www.asocdurpes.lt/forum2013/downloads/I.\%200ZOLA_Peat\%20production\%20in\%202013_ Latvia_05\%2009\%202013-EN.pdf

42 Conducted by the State company "Agriculture Ministry Real Estate", Drainage Department; see: http://www.emps.ee/uus/sites/default/files/Latvian\%20drainage\%20plans\%20for\%202020-E.Grikitis_0.pdf ${ }^{43}$ As recently made for Estonia (Paal \& Leibak 2011).
} 
forest habitats and related species, and the restoration of hydrological regimes in forests.

A country wide inventory of habitats (including peatlands) will improve the knowledge on their actual distribution, conservation status and impacts and provide the necessary data to define restoration priorities for the coming years. This inventory is supposed to begin in 2016 and is scheduled to run over three years.

Furthermore, the National Nature Conservation Agency, ${ }^{44}$ responsible for nature conservation in Latvia, elaborates a "National Conservation and Management Programme for Natura 2000 Sites in Latvia." 45 The programme will be based on a comprehensive analysis of all available data and aims to define challenges for appropriate restoration and protection of Natura 2000 sites, prioritize restoration actions and provide restoration guidelines for each habitat type of EU-wide importance of Latvia (incl. protected peatland habitats). The programme will include the restoration of wetland habitats and the protection of related species of EU-wide importance. The Programme will be published in 2015, whereas in 2016 the publication of the restoration guidelines will follow. Although prepared for Natura 2000 sites, the programme and guidelines will also be applicable to Ramsar sites, since both frameworks are targeted to preserve and enhance biodiversity. The implementation of the priority action plan will lead to additional benefits, e.g. climate change mitigation by decreasing greenhouse gas emissions from drained peatlands. Currently, some restoration actions for peatlands are carried out in Latvia, or are proposed for the nearest future, e.g. the rewetting of the Ramsar site "Northern Bogs" to diminish the drainage impact. ${ }^{46}$ In the nearest future, two wetland areas will be restored in other Ramsar sites: "Lake Engure", that includes fens and the "Pape wetland complex", that hosts raised bogs and fens. This aims is to improve the habitat quality for numerous bird species. The priority sites defined within the national Natura 2000 Programme will serve as priority list for funding restoration by 2020.

\footnotetext{
${ }^{44}$ http://www.daba.gov.lv/public/eng/

45 http://ec.europa.eu/environment/life/project/Projects/index.cfm?fuseaction=search.dspPage\&n_proj_ id $=4283$

46 Project: LIFE13 NAT/LV/000578 LIFE_WETLANDS
} 


\subsubsection{Acknowledgements}

We thank Agnese Priede of the Laboratory of Geobotany at the Institute of Biology (University of Latvia) for her valuable comments on the draft version of this country chapter. Furthermore, we thank Juris Jatnieks (Nature Conservation Agency of Latvia) for collaboration within the "NorBalWet" project and GIS data delivery.

\subsubsection{References}

Aunina L. (2013). Impact of groundwater level tise on vegetation in Melnais Lake Mire Nature Reserve - first results. In: Pakalne M. \& Strazdina L. (eds.), Raised bog management for biological diversity conservation in Latvia. Hansa Print Riga, Rīga, pp. 197-203. Available at: http://www.purvi.lv/files/2014/4/1/augsto_purvu_ apsaimniekosana.pdf

IPCC (2003). Good Practice Guidance for Land Use, and-Use Change and Forestry, Penman J., Gytarsky M., Hiraishi T., Krug T., KrugerD., Pipatti R., Buendia L., Miwa K., Ngara T., Tanabe K. \& Wagner F. (eds.), published by the Institute for Global Environmental Strategies (IGES) for the IPCC, Japan.

IPCC (2006). 2006 IPCC Guidelines for National Greenhouse Gas Inventories, prepared by the National Greenhouse Gas Inventories Programme, Eggleston H.S., Buendia L., Miwa K., Ngara T. \& Tanabe K. (eds). IGES, Japan.

IPCC (2014). 2013 Supplement to the 2006 IPCC Guidelines for National Greenhouse Gas Inventories: Wetlands. Hiraishi T., Krug T., Tanabe K., Srivastava N., Baasansuren J., Fukuda M. \& Troxler T.G. (eds), Published by IPCC, Switzerland.

Jarvis A., Reuter H.I., Nelson A., \& Guevara E. (2008). Hole-filled SRTM for the globe Version 4, available from the CGIAR-CSI SRTM 90m Database. Available at: http://srtm.csi.cgiar.org

Kirstuka I. (ed.) (2004). Economy-wide natural resources flow assessment. The Ministry of Environment of the Republic of Latvia, Latvian Environment Agency, Riga, 87 p.

Latvian Soil Map. Available at: http://eusoils.jrc.ec.europa.eu/library/maps/ country_maps/metadata.cfm?mycountry=LV

Ministry of Environment of the Republic of Latvia, (2004). Economy-wide natural resources flow assessment. Latvian Environment Agency, Riga, Latvia. Available at: http://www.meteo.lv/fs/CKFinderJava/userfiles/files/Vide/Stavokla_parskati/20 04/MFA.pdf

NIS Latvia (2014). Latvia's National Inventory Report. Submission under UNFCCC and the Kyoto Protocol, Riga, Latvia, 439 p. + Annexes. Available at:

http://unfccc.int/national_reports/annex_i_ghg_inventories/national_inventories_s ubmissions/items/8108.php

Pakalne M. \& Aleksāns O. (2015). Latvia. In: Joosten, H., Tanneberger, F. \& Moen, A. (eds.), Mires and peatlands of Europe: Status, distribution, and nature conservation Schweizerbart Science Publishers, Stuttgart.

Paal J. \& Leibak E. (2011). Estonian mires: Inventory of habitats. Eestimaa Looduse Fond, Tartu, Estonia, 174 p. XXXV plates +11 p of photos. 


\subsection{Lithuania}

\subsubsection{Characterization of the country}

Figure 1: NorBalWet countries covered in this report (grey); Lithuania (dark grey)

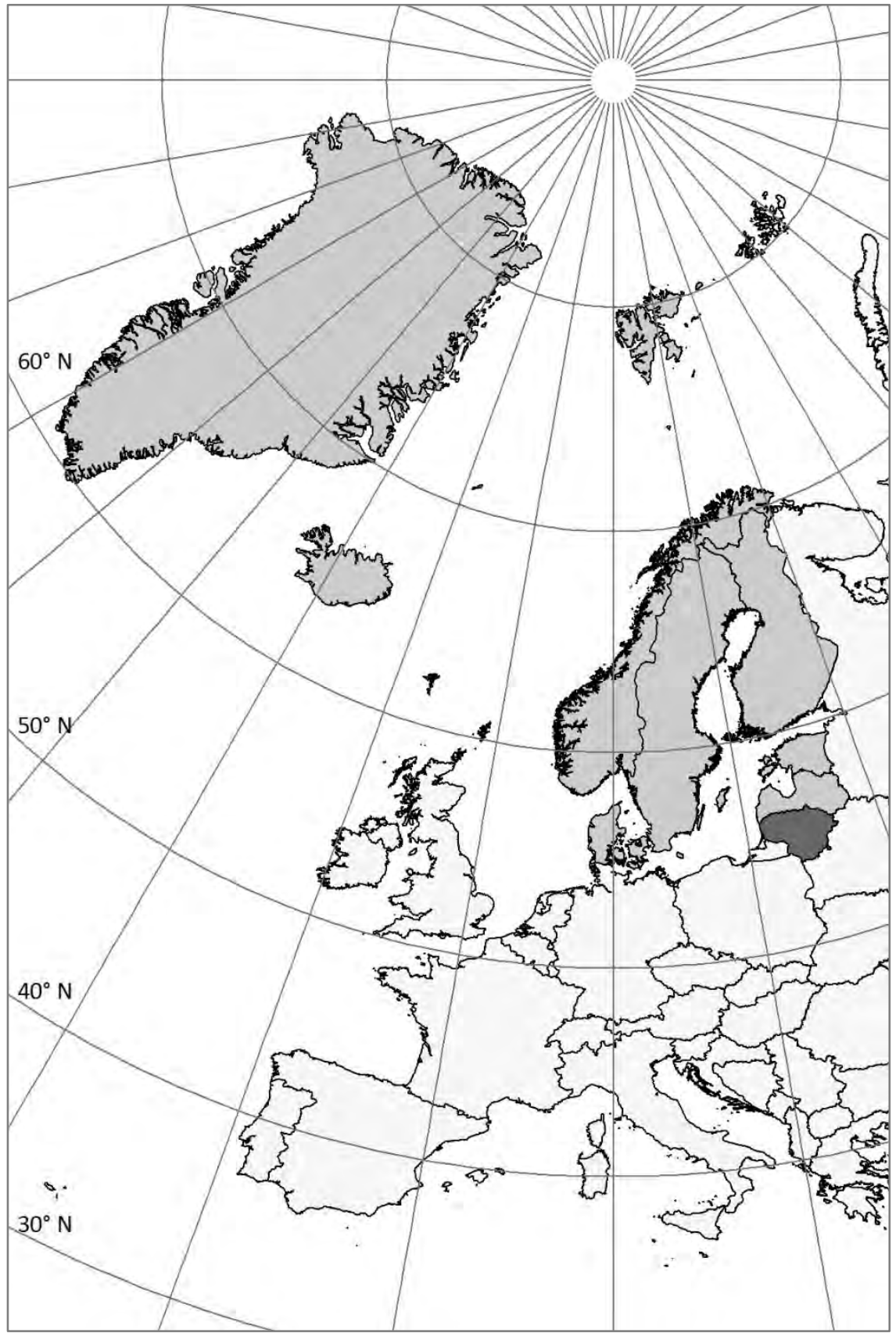


Lithuania (Figure 1) lies between $53^{\circ}$ and $57^{\circ} \mathrm{N}$, and between $21^{\circ}$ and $27^{\circ}$ E, 47 and covers an area of $65,300 \mathrm{~km}^{2}$. The country is situated on the western part of the eastern European Precambrian platform. The relief is mainly determined by the last two glacial periods. Quaternary deposits of varying thickness (40-314 m) cover Pre-Quaternary rocks. The land is fairly even and slightly undulating (Mierauskas \& Taminskas 2015).

In western Lithuania the climate is determined by marine weather masses; in the eastern part it is more continental. The average annual precipitation varies from $520 \mathrm{~mm}$ (in Mūša-Nemunèlis plain) up to 901 $\mathrm{mm}$ in the Baltic Sea coastal area. Most precipitation falls during the vegetation period. The average air temperature in January varies from $0.5^{\circ} \mathrm{C}$ in the West to $-2.5^{\circ} \mathrm{C}$ in the East, in July from $16.5^{\circ} \mathrm{C}$ in the West to $18.5^{\circ} \mathrm{C}$ in the East (Mierauskas \& Taminskas 2015).

\subsubsection{Peatland diversity}

Peatlands are one of the most characteristic elements of the landscape of Lithuania. Considering the peatland distribution, Purvinas \& Seibutis (1957) distinguished three provinces: the western province where peatlands cover $29 \%$ of area, the central province with $27 \%$, and the southeastern province with $44 \%$ of peatlands, respectively (Mierauskas \& Taminskas 2015). Until the beginning of the 20th century, the various ethnic regions of Lithuania had their own terms for permanent wetlands. Since the end of the 19th century the term "pelkè" was the most common term for "mires" (Mierauskas \& Taminskas 2015). The term "durpynai" means "peatlands" - an area with a peat layer of at least 30 cm depth. Natural peatlands (mires) are divided into three types according to their hydrological conditions and vegetation. Fens (žemapelkès) are fed by mineral rich ground and surface water. They develop in low lying areas as river valleys and deltas, but also in shallow lakes (Mierauskas \& Taminskas 2015). Typical plants include Alnus glutinosa, Betula, Salix, Carex and Juncus species as well as Equisetum fluviatile and brown mosses. Raised bogs (aukštapelkès) are predominantly fed by precipitation water. These peatlands develop mainly on watersheds in fens and have often a convex surface. The vegetation indicates nutrient poor and acid conditions and typical plants are Pinus sylvestris, Ledum palustre, Calluna vulgaris, as well as Vaccinium, Eriophorum, and Sphag-

${ }^{47}$ http://en.wikipedia.org/wiki/Lithuania 
num species (Mierauskas \& Taminskas 2015). Transitional mires (tarpinès pelkès) are a transitional stage between the typical fens and typical raised bogs (as described above) and characterised by species typical both for fens and raised bog (Mierauskas \& Taminskas 2015).

\subsubsection{Peatland degradation}

Traditionally, peat and peatland plants were used for construction, medicine, food, as insulation material in houses (dried Sphagnum), and peatlands itself as shelter for the people during wars. More intensive exploitation started with the mining of fuel peat and peat litter at the beginning of the 19th century. Peat mining particularly intensified in the period 1919-1940 (Lithuanian independency), when peatlands were additionally used for cattle grazing and harvesting of hay (Mierauskas \& Taminskas 2015). The entire peat industry was nationalised in 1940 and many new peat companies were established. After the re-established independency of Lithuania in 1990 peat extraction decreased alongside with the decline of the entire economy. From 2000 to 2008 peat extraction reached again 3.16 million $\mathrm{m}^{3}$ per year. Nowadays, about $80 \%$ of the extracted peat of Lithuania is exported to EU countries (Morkunaite \& Veitas 2011). In spite of the recent recession in economy, plans exist to increase peat extraction.

Intensive land amelioration and the use of peat as a fertilizer started when the agricultural area was enlarged in the Soviet period. At present, undisturbed peatlands have become one of the most threatened habitats in Lithuania. Decades of intensive land reclamation especially for agriculture and peat extraction led to the disappearance of $70-80 \%$ of the mires. Actually, even most peatlands in the strict nature reserves are affected by drainage.

According to the "Fourth National Report of the Republic of Lithuania to the Convention on Biological Diversity" (2009),48 during the last decades of the 20th century, $70 \%$ of the wetlands have been lost. The main reasons are water pollution, drop of groundwater level, eutrophication, overgrowing with shrubs and trees, invasion of new species, direct human activities (e.g. tourism) and use of non-timber resources. Even fens that were not directly affected by land reclamation, became noticeably drier due to the general drop of groundwater table. Communities of moss and graminoid species are being replaced by trees and shrubs. The most valu-

${ }^{48}$ available at: http://www.cbd.int/doc/world/lt/lt-nr-04-en.pdf 
able bog and wetland habitats are included in the wetland complexes of the Nemunas River delta: reeds, flooded meadows and forests, large bogs (e.g. "Čepkeliai" bog: 5,858 ha, "Kamanos" bog: 2,434 ha, "Artoji" bog: 5,693 ha), shallow eutrophic lakes (e.g. "Žuvintas": 6,847 ha), fishery ponds, and wet and swampy forests (e.g. "Rūdninkai" and "Žalioji" woods). All wetlands, and especially the alkaline fens, host a high number of rare and endangered plant communities and protected plant species. Most plant communities of Lithuania that need protection grow in water bodies, meadows and wetlands.

Of the 54 communities that are listed in "The Lithuanian Red Data Book of Plant Communities" 30 communities occur in wetlands and water bodies. 19 of them were grouped in categories 1 (rare communities throughout their distribution area in Lithuania) and 2 (rare communities with their distribution limit across Lithuania). ${ }^{49}$ Additionally, the status of wetlands in Lithuania is highly depending on size: Small wetlands have been destroyed by land reclamation for agriculture and drainage for forest improvement. Since these small wetlands enhance the mosaic character of a landscape and render ecotonal effects, they belong to the most valuable sites for preserving biodiversity..$^{50}$ The main cause of the decline of bird population in Lithuania is destruction of their habitats. Waterfowl populations are the most threatened ones due to draining of small bogs and wetlands, hunting during migration period, etc. Especially fens with small sedge vegetation (class: ScheuchzerioCaricetea) are rare because only few unchanged habitats of this type remain and the number is continuously decreasing.

49 Biodiversity "Conservation Strategy and Action Plan of Lithuania" (1996); available at: https://www.cbd.int/doc/world/lt/lt-nbsap-01-en.pdf

50 http://www.cbd.int/doc/world/lt/lt-nr-04-en.pdf 


\subsubsection{Current peatland: location, extent, status, land use and greenhouse gas emissions}

\section{Material and Methods}

To assess the location and extent of peatlands and the land use applied, we used:

- the vector dataset "Map of Peatlands and Mires in Lithuania" (2005; scale 1:200,000) from the Lithuanian Geological Survey. ${ }^{51}$ This dataset differentiates between "raised bogs", "transition bogs", "fens", "peat covered depressions and hollows" and "undetermined type of wetland". We adopted this classification unchanged, but renamed "transition bogs" to "transition peatlands".

The "Map of Peatlands and Mires in Lithuania" already classified the different peatland types according to drainage status and land use: drained (MELIORUOTO), forest (MIŠKAS) and peat extraction (DURPYNAS). We used these data unchanged, but renamed the land use types to: "undrained open", "undrained forested", "drained forested", "drained agriculture" and "drained peat extraction" as shown in Table 1.

Table 1: Peatland types and land use as stratified in the GIS data set "Map of Peatlands and Mires in Lithuania" (Lithuanian Geological Survey). Land use types do not correspond to UNFCCC/IPCC land use categories

\begin{tabular}{|c|c|c|c|c|c|c|c|c|}
\hline \multirow[t]{2}{*}{ Land use types } & \multicolumn{5}{|c|}{ Peatland/wetland types } & \multicolumn{3}{|c|}{ Land use } \\
\hline & $\begin{array}{l}\text { Raised } \\
\text { bog }\end{array}$ & $\begin{array}{l}\text { Transition } \\
\text { peatlands }\end{array}$ & Fen & $\begin{array}{l}\text { Peat covered } \\
\text { depressions } \\
\text { and hollows }\end{array}$ & $\begin{array}{l}\text { Undetermined } \\
\text { type of wetland }\end{array}$ & $\begin{array}{l}\text { Peat } \\
\text { extraction }\end{array}$ & Drained & Forested \\
\hline Undrained open & $x$ & $x$ & $x$ & $x$ & $x$ & & & \\
\hline Undrained forested & $x$ & $x$ & $x$ & $x$ & $x$ & & & $x$ \\
\hline Drained forested & $x$ & $x$ & $x$ & $x$ & $x$ & & $x$ & $x$ \\
\hline Drained agriculture & $x$ & $x$ & $x$ & $x$ & $x$ & & $x$ & \\
\hline Drained peat extraction & $x$ & $x$ & $x$ & $x$ & $x$ & $x$ & $x$ & \\
\hline
\end{tabular}

51 https://www.lgt.lt/index.php?lang=en 
According to satellite images from Esri Basemaps (Esri ArcGIS), the category "undetermined type of wetland" predominantly includes forested areas next to raised bogs, transition peatlands and fens, and additionally some depressions and hollows. We assume that a considerable part is forested peatland, but we did not include this category in the peatland area used for emission calculation (see Table 5). The category "peat covered depressions and hollows" includes many small and often forested peatlands.

For error analysis of the GIS dataset we visually checked the data of the "Map of Peatlands and Mires in Lithuania" with satellite images of Google Earth, OpenCycleMap OCM (http://www.opencyclemap.org/) and the World Imagery layer (Esri ArcGIS). It appeared that, in general, the dataset represents the peatlands sufficiently, but inaccuracies with respect to peatland borders exist, and small and forested peatlands are probably somewhat underrepresented.

To assess the extent of peatlands and the land use applied, we consulted furthermore:

- the most recent assessment of the peatlands of Lithuania from Taminskas et al. (2012).

This compilation used GIS databases and data sets to delineate wetlands and assess their status across Lithuania. Additional information was found in various cadastre, topographic, and orthophotographic maps. Peatlands (all areas with peat layer $>30 \mathrm{~cm}$ deep) were calculated according the "Soil Database of Lithuania" (scale 1:10,000), the "State Forest Cadastre of Lithuania", and the "Map of Peatlands and Mires in Lithuania" (see above).

To estimate the area and emissions from drained and used organic soils, we used:

- the most recent National Inventory Submission of Lithuania to the United Nations Framework Convention on Climate Change (NIS ${ }^{52}$ Lithuania 2014).

52 The National Inventory Submission ("NIS") consists of the National Inventory Report ("NIR") and the Common Reporting Format ("CRF"). Since both the NIR and the CRF were used, we will refer further to the complete National Inventory Submission of Lithuania (NIS Lithuania 2014). 
The National Inventory Submission for Lithuania (NIS Lithuania 2014) to the Climate Convention UNFCCC provides information on the distribution and use of drained organic soils derived from the National Forest Inventory (NFI). The NFI is based on continuous sampling and GIS integration. The systematic grid (16,325 permanent sample plots) covers all land categories. Sampling is conducted using a $4 \times 4 \mathrm{~km}$ systematic grid. The total number of plots measured over the 5 -year inventory cycle reaches a sampling intensity of one sample plot per 400 ha. Peat extraction areas are monitored by the Lithuanian Geological Service (NIS Lithuania 2014). Definition of organic soils is in line with the definition and requirements of IPCC 2003, hence organic soils are identified with peat and peaty soil layer equal to or being more than $30 \mathrm{~cm}$ of the total thickness. (NIS Lithuania 2014).

We calculated the $\mathrm{CO}_{2}$ emissions of the land use types of the GIS data set "Map of Peatlands and Mires in Lithuania" (Table 1) and the land use types of Taminskas et al. (2012, Table 7) using the IPCC (2014) default emission factors for $\mathrm{CO}_{2}$ for the Temperate climate/vegetation zone. For "drained agriculture" an average default value of all emission factors for "Cropland" and "Grassland" was used (20.90 t CO $2 /$ ha/yr).

Table 2: Emission factors for $\mathrm{CO}_{2}$ used for calculating the emissions of areas in the GIS data set "Map of Peatlands and Mires in Lithuania" and Taminskas et al. (2012). Land use types do not correspond to UNFCCC/IPCC land use categories

\begin{tabular}{|c|c|c|}
\hline Land use type & $\begin{array}{r}\text { Emission factor (EF) } \\
t \mathrm{CO}_{2} / \mathrm{ha} / \mathrm{yr}\end{array}$ & Emission factor (EF) comments \\
\hline Drained forested & 9.5 & EF "Forest Land, drained" \\
\hline Drained agriculture & 20.9 & average of all EFs for Cropland and Grassland \\
\hline Drained peat extraction & 10.3 & EF "Peatland Managed for Extraction" \\
\hline
\end{tabular}

For emission calculation the NIS Lithuania (2014) used default emission factors for $\mathrm{CO}_{2}$ for drained organic soils from IPCC (2003; Tier 1); (cf. Table 3). Since these emission factors are outdated, we recalculated the emissions using the new Tier 1 emission factors from IPCC (2014) (Table 3,6$)$. This emission recalculation resulted in approximately eight times higher annual emissions (see Table 6). 
Table 3: Emission factors for $\mathrm{CO}_{2}$ as used in NIS Lithuania (2014) and the IPCC (2014) Tier 1 emission factors used for emission recalculation. Land use categories according to UNFCCC/IPCC

\begin{tabular}{lcr} 
IPCC category & Emission factors for $\mathrm{CO}_{2}$ in $\mathbf{~} \mathrm{CO}_{2} / \mathbf{h a} / \mathbf{y r}$ & \\
& NIS Lithuania (2014) & IPCC (2014) \\
Forest Land & 2.5 & 9.5 \\
Cropland & 3.7 & 29.0 \\
Grassland & 0.9 & $20.9^{1)}$ \\
Peat extraction & 4.0 & 10.3 \\
\hline
\end{tabular}

1) Deeply drained: average of EF “Grassland, drained, nutrient-poor" and "Grassland, deep-drained, nutrient-rich" (excl. EF "Grassland, shallow drained, nutrient-rich" from IPCC 2014).

To address utilization pressure and threat of peatland types and mire habitats in Lithuania, we used:

- the "Fourth National Report of the Republic of Lithuania to the Convention on Biological Diversity" (2009) 53

- the "Biodiversity Conservation Strategy and Action Plan of Lithuania" (1996)..$^{54}$

Carbon loss from DOC (Dissolved Organic Carbon) is not included in this study.

Peat carbon stock data were derived from Gasiūnienè and Lesiukova (2007).

\section{Results}

The dataset "Map of Peatlands and Mires in Lithuania" (see Material and Methods above) shows that peatlands cover in total $474.6 \times 10^{3}$ ha of Lithuania, including $67.0 \times 10^{3}$ ha of Raised bog, $226.6 \times 10^{3}$ of Fen, $8.8 \times$ $10^{3}$ ha of Transition peatland, and $172.3 \times 10^{3}$ of Peat covered depressions and hollows (Table 4). The western and south-eastern provinces of Lithuania host much more peatland than the central provinces. The largest areas of peatland occur in the Daugava basin and the Žeimena subbasin (Taminskas 2012). Extensive peatlands are situated in the South of Šiauliai, Kaunas, Vilnius and Varèna; most of the small peatlands are concentrated in eastern Lithuania (Figure 2).

\footnotetext{
53 available at: http://www.cbd.int/doc/world/lt/lt-nr-04-en.pdf

${ }_{54}$ available at: https://www.cbd.int/doc/world/lt/lt-nbsap-01-en.pdf
} 
Table 4: Area, drainage status and emissions of peatland types in Lithuania (based on the "Map of Peatlands and Mires in Lithuania"). For details see Table 5 (below)

\begin{tabular}{|c|c|c|c|c|c|c|}
\hline \multirow[b]{2}{*}{ Peatland type } & \multirow[b]{2}{*}{$\begin{array}{r}\text { Total Area } \\
\left(10^{3} \mathrm{ha}\right)\end{array}$} & \multicolumn{2}{|c|}{ Undrained } & \multicolumn{2}{|c|}{ Drained } & \multirow{2}{*}{$\begin{array}{l}\text { Emissions } \\
\qquad \mathrm{Mt} \mathrm{CO} / \mathrm{yr}\end{array}$} \\
\hline & & (10 ha) & $\%$ & (10 ha) & $\%$ & \\
\hline Raised Bog & 67.0 & 12.0 & 17.9 & 55.0 & 82.1 & 0.68 \\
\hline Transition peatland & 8.8 & 0.9 & 10.3 & 7.9 & 89.7 & 0.10 \\
\hline Fen & 226.6 & 13.9 & 6.1 & 212.7 & 93.9 & 3.57 \\
\hline Peat covered depressions and hollows & 172.3 & 13.6 & 7.9 & 158.6 & 92.1 & 2.89 \\
\hline$\sum$ subtotals & & 40.4 & 8.5 & 434.2 & 91.5 & \\
\hline$\sum$ total & & & & & $474.6^{11}$ & 7.24 \\
\hline
\end{tabular}

${ }^{1)}$ Excluded are $37.4 \times 10^{3}$ ha of "Undetermined type of wetland", which may be predominantly peatland.

According to the GIS data set "Map of Peatlands and Mires in Lithuania" (see Material and Methods above) $91 \%$ of the peatlands of Lithuania are impacted by drainage. Their emission amounts to $7.2 \mathrm{Mt} \mathrm{CO}_{2}$ per year (Table 4).

Of the $67.0 \times 10^{3}$ ha of Raised bogs in Lithuania, $12.0 \times 10^{3}$ ha $(17.9 \%)$ still remain in a natural state with open or woody vegetation (Figure 3), whereas $55.0 \times 10^{3}$ ha $(82.1 \%)$ is drained and used for forestry, agriculture or peat extraction, with associated emissions of $0.68 \mathrm{Mt}$ $\mathrm{CO}_{2}$ per year (Table 5 ).

Transition peatlands cover $8.8 \times 10^{3}$ ha, of which $0.9 \times 10^{3}$ ha $(10.3 \%)$ remain in a natural state with open or woody vegetation (Figure 4). $7.9 \times 10^{3}$ ha (89.7\%) is used for forestry or agriculture, with associated emissions of $0.1 \mathrm{Mt} \mathrm{CO}_{2}$ per year (Table 5).

Fens cover in total $226.6 \times 10^{3}$ ha, of which $13.9 \times 10^{3}$ ha (6.1\%) still remain in a natural state with open or woody vegetation (Figure 3). $212.7 \mathrm{x}$ $10^{3}$ ha $(93.9 \%)$ of the total fen area is used for forestry, agriculture or peat extraction, with associated emissions of $3.5 \mathrm{Mt} \mathrm{CO}_{2}$ per year (Table 5).

"Peat covered depressions and hollows" cover in total $172.3 \times 10^{3}$ ha, of which $13.6 \times 10^{3}$ ha (7.9\%) still remain in a natural state with open or woody vegetation (Figure 4). $158.6 \times 10^{3}$ ha $(92.1 \%)$ of this land category is used for forestry, agriculture or peat extraction, with associated emissions of $2.8 \mathrm{Mt} \mathrm{CO}_{2}$ per year (Table 5).

The already mentioned $37.4 \times 10^{3}$ ha of "Undetermined type of wetlands" also probably include some peatlands, because $1.7 \times 10^{3}$ ha was classified as "peat extraction area" (Table 5). $29.2 \times 10^{3}$ ha of this area $(78 \%)$ is used for forestry, agriculture or peat extraction. 
Table 5: Extent of Raised bog, Fen, Transition peatland and Peat covered depressions and hollows in Lithuania (based on the "Map of Peatlands and Mires in Lithuania"), and associated $\mathrm{CO}_{2}$ emissions for various land use types. Carbon loss without DOC. Land use types do not correspond to UNFCCC/IPCC land use categories

\begin{tabular}{|c|c|c|c|c|}
\hline Peatland / land use type & $\begin{array}{r}\text { Area } \\
\left(10^{3} \text { ha }\right)\end{array}$ & $\begin{array}{r}\text { Emission factor } \\
\text { (t C/ha/yr) }\end{array}$ & & $\begin{array}{r}\text { Emissions } \\
(\mathrm{Mt} \mathrm{CO} / \mathrm{yr})\end{array}$ \\
\hline \multicolumn{5}{|l|}{ Raised bog } \\
\hline undrained open & 1.7 & \pm 0 & & \pm 0 \\
\hline drained agriculture & 11.7 & 20.90 & & 0.25 \\
\hline undrained forested & 10.3 & \pm 0 & & \pm 0 \\
\hline drained forested & 17.9 & 9.5 & & 0.17 \\
\hline drained peat extraction & 25.4 & 10.3 & & 0.26 \\
\hline$\sum$ Subtotal & 67.0 & & 0.68 & \\
\hline \multicolumn{5}{|l|}{ Transition peatland } \\
\hline undrained open & 1 & \pm 0 & & \pm 0 \\
\hline drained agriculture & 2.4 & 20.90 & & 0.05 \\
\hline undrained forested & 0.8 & \pm 0 & & \pm 0 \\
\hline drained forested & 3.6 & 9.5 & & 0.03 \\
\hline drained peat extraction & 1.9 & 10.3 & & 0.02 \\
\hline$\sum$ Subtotal & 8.8 & & 0.10 & \\
\hline \multicolumn{5}{|l|}{ Fen } \\
\hline undrained open & 4.2 & \pm 0 & & \pm 0 \\
\hline drained agriculture & 134.0 & 20.9 & & 2.80 \\
\hline undrained forested & 9.7 & \pm 0 & & \pm 0 \\
\hline drained forested & 56.4 & 9.5 & & 0.54 \\
\hline drained peat extraction & 22.3 & 10.3 & & 0.23 \\
\hline$\sum$ Subtotal & 226.6 & & 3.57 & \\
\hline \multicolumn{5}{|l|}{ Peat covered depressions and hollows } \\
\hline undrained open & 13.6 & \pm 0 & & \pm 0 \\
\hline drained agriculture & 121.1 & 20.9 & & 2.53 \\
\hline drained forested & 37.4 & 9.5 & & 0.36 \\
\hline drained peat extraction & 0.1 & 10.3 & & \pm 0 \\
\hline$\sum$ Subtotal & 172.3 & & & 2.89 \\
\hline $\begin{array}{l}\sum \text { Total (excl. "Undetermined type of } \\
\text { wetland") }\end{array}$ & 474.6 & & 7.24 & \\
\hline \multicolumn{5}{|l|}{ Undetermined type of wetland } \\
\hline undrained open & 0.7 & \pm 0 & & \pm 0 \\
\hline drained agriculture & 13.6 & 20.9 & & 0.28 \\
\hline undrained forested & 7.5 & \pm 0 & & \pm 0 \\
\hline drained forested & 13.8 & 9.5 & & 0.13 \\
\hline drained peat extraction & 1.7 & 10. & & 0.02 \\
\hline$\sum$ Subtotal & 37.4 & & & 0.43 \\
\hline
\end{tabular}

According to Gasiūnienė \& Lesiukova (2007) the in detail explored peat resources of Lithuania amount to $2.9 \times 10^{9} \mathrm{~m}^{3}$ data from the State Geological Information System). This is approximately one third of the total peat resources. Due to drainage, degradation and peat extraction the peat carbon stock is continuously decreasing. 
Figure 2: Location and extent of peat covered areas in Lithuania, specified for A) peatland type (category "undetermined type of wetland" included), and B) land use type. Based on the GIS dataset "Map of Peatlands and Mires in Lithuania" (see Material and Methods above). Land use types do not correspond to UNFCCC/IPCC land use categories
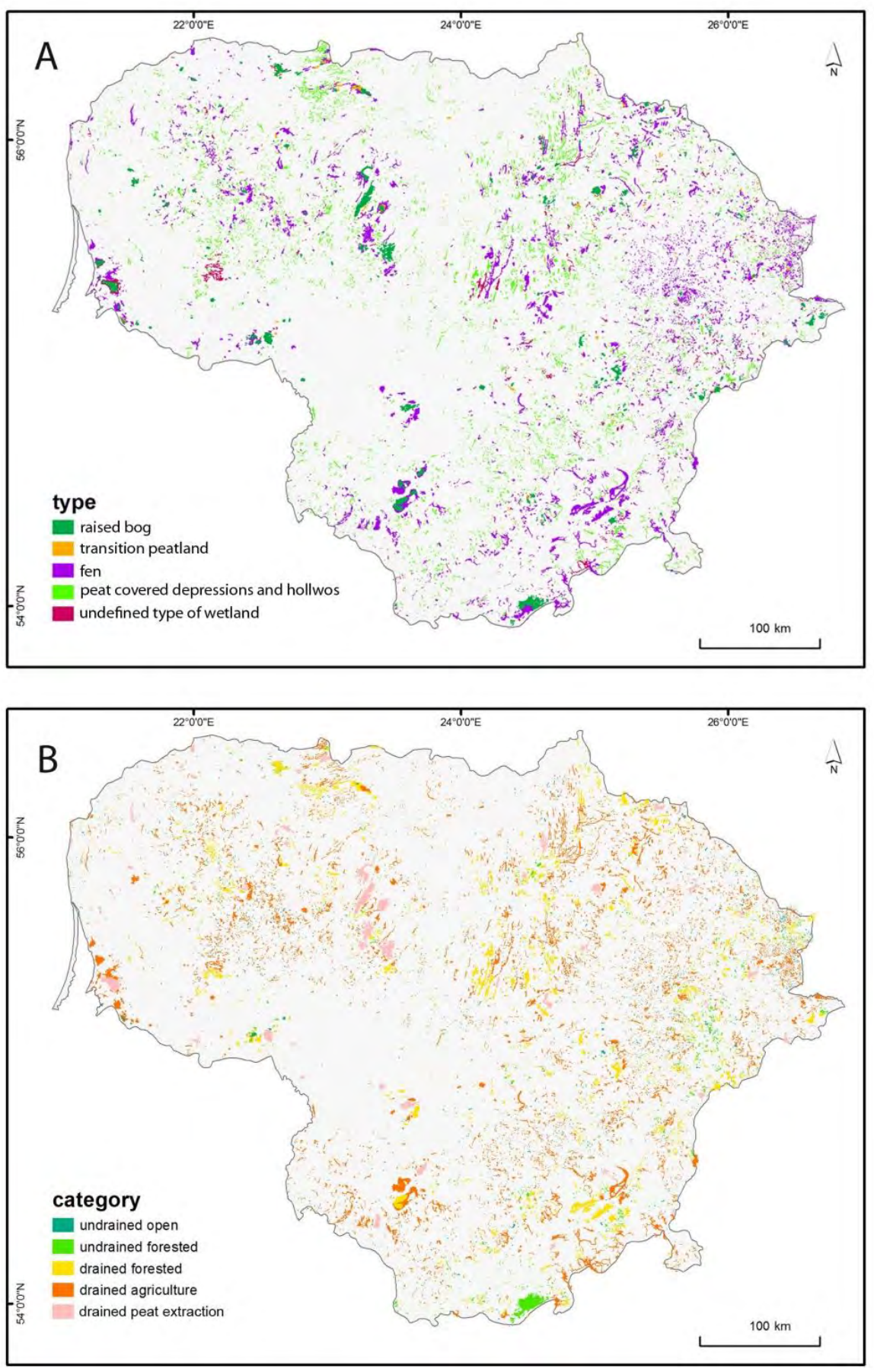
Figure 3: Location, extent and drainage status specified for A) raised bogs and B) fens in Lithuania. Based on the GIS dataset "Map of Peatlands and Mires in Lithuania" (see Material and Methods above)
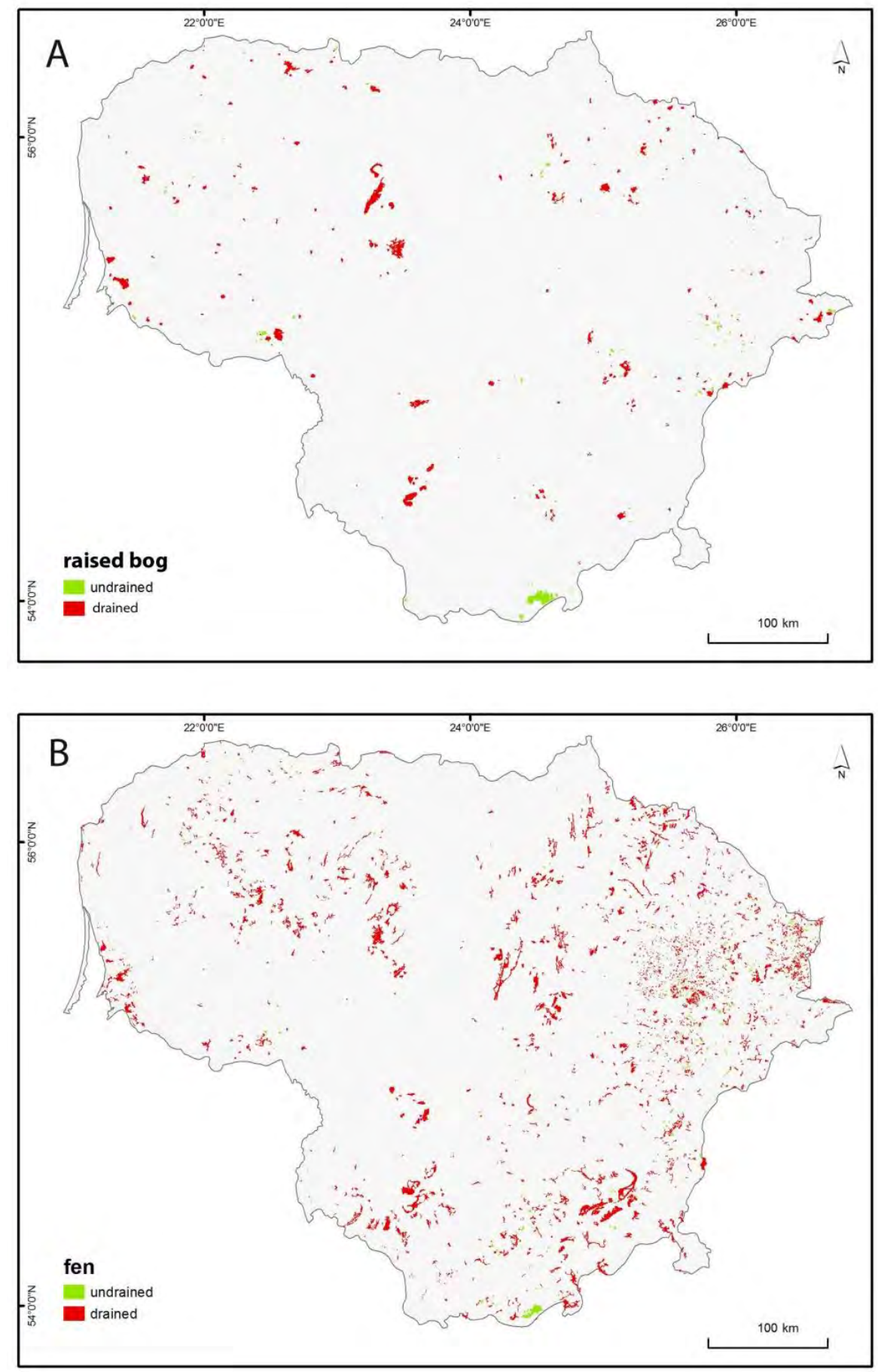
Figure 4: Location, extent and drainage status specified for A) transition peatland and B) "peat covered depressions and hollows" in Lithuania. Based on the GIS dataset "Map of Peatlands and Mires in Lithuania" (see Material and Methods above)
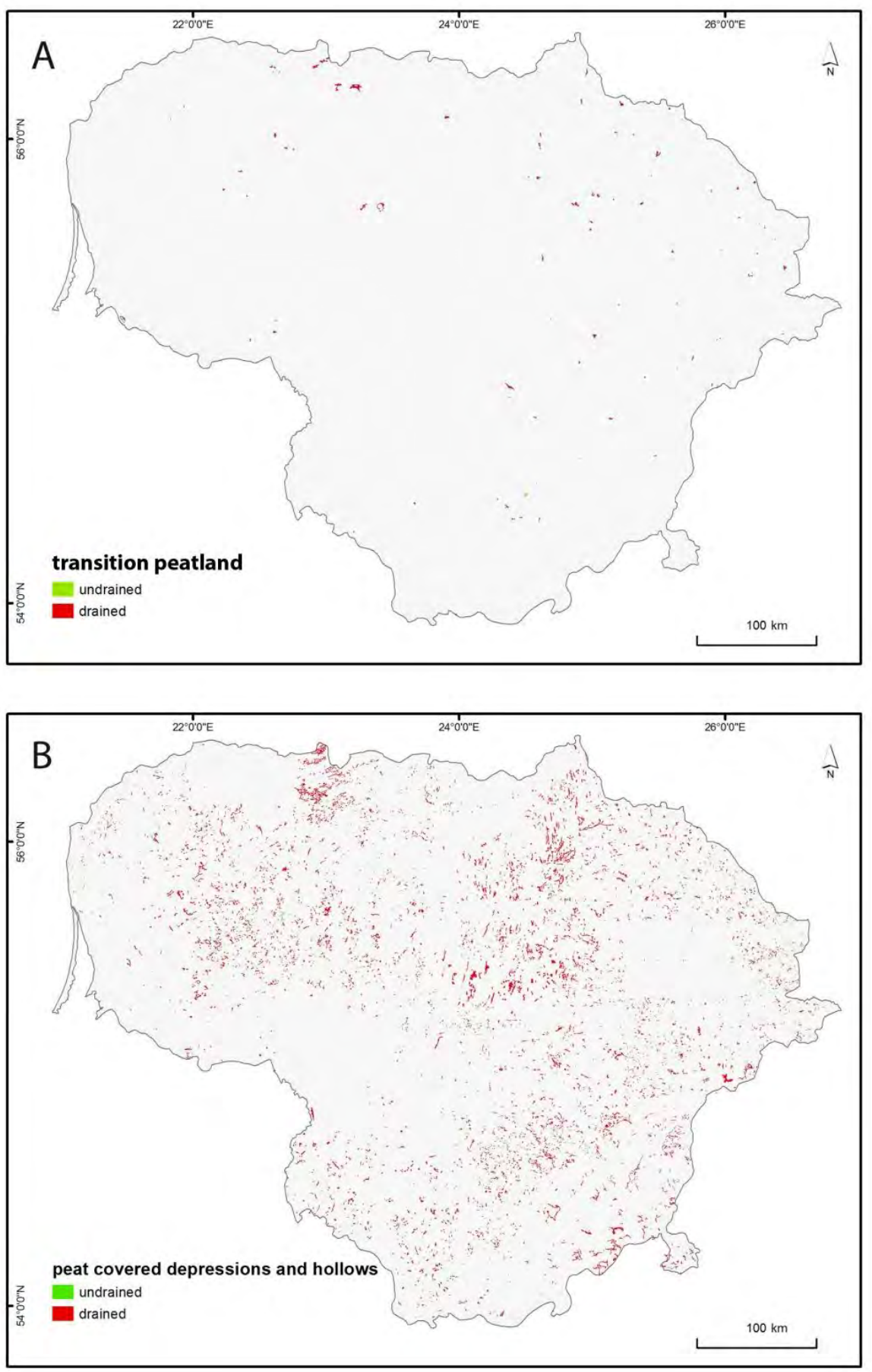
The National Inventory Submission 2014 (NIS Lithuania 2014) reported $172.6 \times 10^{3}$ ha of Forest Land on drained organic soil, $14.8 \times 10^{3}$ ha of Cropland on drained organic soil, $160.9 \times 10^{3}$ ha of Grassland on drained organic soil, and $13.8 \times 10^{3}$ ha of organic soil drained for Peat extraction (Table 6). Drainage and use of these areas lead, according to the NIS Lithuania (2014), to an annual $\mathrm{CO}_{2}$ emission of $0.7 \mathrm{Mt}$. Using the latest IPCC (2014) default values for $\mathrm{CO}_{2}$ for the Temperate climate/vegetation zone, these emissions increase to annually $5.6 \mathrm{Mt} \mathrm{CO}_{2}$ (Table 6). The NIS Lithuania (2014) additionally reported an area of $170.4 \times 10^{3}$ ha of undrained Forest Land on organic soil, which would lead to a total area of Forest Land on organic soil of $343.0 \times 10^{3}$ ha. The total area of organic soil reported in NIS Lithuania (2014) would be thus $532.5 \times 10^{3}$ ha (Table 7). Not reported and therefore not included are undrained and open areas on organic soil (cf. "undrained peatland, 55 open" as reported by Tamiskas et al. (2012).

According to Taminskas et al. (2012) the total peatland area of Lithuania is $646.0 \times 10^{3}$ ha, with $467.9 \times 10^{3}$ ha of drained and $178.1 \times 10^{3}$ ha of undrained peatlands (Table 7). The area of drained peatlands fits well with the drained peatland area we have elaborated based on the "Map of Peatlands and Mires in Lithuania" (434.2 x $10^{3}$ ha, excluded are $37.4 \mathrm{x}$ $10^{3}$ ha of "undetermined type of wetland"; cf. Table 4, 5).

\section{Discussion}

In order to review the importance of peatlands in Lithuania for climate change mitigation and restoration potential, we analysed and integrated geospatial and other data.

Since the geospatial explicit dataset "Map of Peatlands and Mires in Lithuania" probably does not cover all small and forested areas, we regard the data of Taminskas et al. (2012) as most comprehensive and reliable. They integrate several datasets including the "Map of Peatlands and Mires in Lithuania" we have used (see Material and Methods above). According to Taminskas et al. (2012) probably more undrained peatlands still exist (mainly forested, Table 7) than we have elaborated solely based on the "Map of Peatlands and Mires in Lithuania": rather 28\% of the total peatland area (instead of 8.5\%; cf. Table 4). According to Taminskas et al. (2012), drained peatlands amount to $72 \%$ of the total peatland area. Table 7 gives the area estimates elaborated for land use

55 Mind that this is peatland and not organic soil. 
types on drained peatlands from Taminskas et al. (2012) and the associated $\mathrm{CO}_{2}$ emissions (left columns). The resulting area of drained peatlands (467.9 × $\left.10^{3} \mathrm{ha}\right)$ and the related annual emissions (7.7 $\left.\mathrm{Mt} \mathrm{CO}_{2}\right)$ fit well with the area of drained peatlands according to the "Map of Peatlands and Mires in Lithuania" (474.6 x $10^{3} \mathrm{ha}$ ) and the respective annual emissions (7.2 $\mathrm{Mt} \mathrm{CO}_{2}$; Table 4, 5 and 7). 
Table 6: Drained organic soil areas, land use types and associated $\mathrm{CO}_{2}$ emissions. Left part of the table: as reported in the NIS Lithuania (2014) to the UNFCCC. Right part: recalculation of emissions with the new IPCC (2014) default values for $\mathrm{CO}_{2}$ for Temperate Climates

\begin{tabular}{|c|c|c|c|c|c|c|c|}
\hline \multirow[t]{2}{*}{ Lithuania } & \multicolumn{5}{|c|}{ National Inventory Submission 2014} & \multicolumn{2}{|c|}{$\begin{array}{l}\text { Recalculated according to } \\
\text { IPCC } 2014\end{array}$} \\
\hline & $\begin{array}{r}\text { Area of organic soil } \\
\left(10^{3} \mathrm{ha}\right)\end{array}$ & $\begin{array}{r}\text { Net carbon stock change } \\
\text { per area } \\
\left(\mathrm{t} \mathrm{CO}_{2} / \mathrm{ha} / \mathrm{yr}\right)\end{array}$ & $\begin{array}{r}\text { Emissions } \\
\left(\mathrm{Mt} \mathrm{CO}_{2} / \mathrm{yr}\right)\end{array}$ & $\begin{array}{r}\text { EF } \\
\text { TIER }\end{array}$ & Uncertainty EF \% & $\begin{array}{r}\text { Net carbon stock } \\
\text { change per area } \\
\left(\mathrm{t} \mathrm{CO}_{2} / \mathrm{ha} / \mathrm{yr}\right)\end{array}$ & $\begin{array}{r}\text { Emissions } \\
\left(\mathrm{Mt} \mathrm{CO}_{2} / \mathrm{yr}\right)\end{array}$ \\
\hline $\begin{array}{l}\text { Land Use Category } \\
\text { Forest Land remaining } \\
\text { Forest Land }\end{array}$ & 163.6 & 2.5 & 0.41 & 1 & 1) & 9.5 & 1.56 \\
\hline $\begin{array}{l}\text { Cropland converted to } \\
\text { Forest Land }\end{array}$ & 1.2 & 2.5 & 0.00 & & & 9.5 & 0.01 \\
\hline $\begin{array}{l}\text { Grassland converted to } \\
\text { Forest Land }\end{array}$ & 6.2 & 2.5 & 0.02 & & & 9.5 & 0.06 \\
\hline $\begin{array}{l}\text { Wetlands converted to } \\
\text { Forest Land }\end{array}$ & 1.3 & 2.5 & 0.00 & & & 9.5 & 0.01 \\
\hline $\begin{array}{l}\text { Settlement converted } \\
\text { to Forest Land }\end{array}$ & 0.1 & 2.5 & 0.00 & & & 9.5 & 0.00 \\
\hline $\begin{array}{l}\text { Other Land converted } \\
\text { to Forest Land }\end{array}$ & $0: 1$ & 2.5 & 0.00 & & & 9.5 & 0.00 \\
\hline$\sum$ Forest Land & 172.6 & & 0.43 & & & & 1.64 \\
\hline $\begin{array}{l}\text { Cropland remaining } \\
\text { Cropland }\end{array}$ & 9,6 & 3.7 & 0.04 & 1 & 90 & 29.0 & 0.28 \\
\hline $\begin{array}{l}\text { Grassland converted to } \\
\text { Cropland }\end{array}$ & 5.2 & 3.7 & 0.02 & & & 29.0 & 0.15 \\
\hline $\begin{array}{l}\text { Wetlands converted to } \\
\text { Cropland }\end{array}$ & 0.02 & 3.7 & 0.00 & & & 29.0 & 0.00 \\
\hline $\begin{array}{l}\text { Settlement converted } \\
\text { to Cropland }\end{array}$ & 0.01 & 3.7 & 0.00 & & & 29.0 & 0.00 \\
\hline$\sum$ Cropland & 14.8 & & 0.05 & & & & 0.43 \\
\hline Grassland remaining & 87.9 & 0.9 & 0.08 & 1 & 90 & 20.9 & 1.84 \\
\hline
\end{tabular}




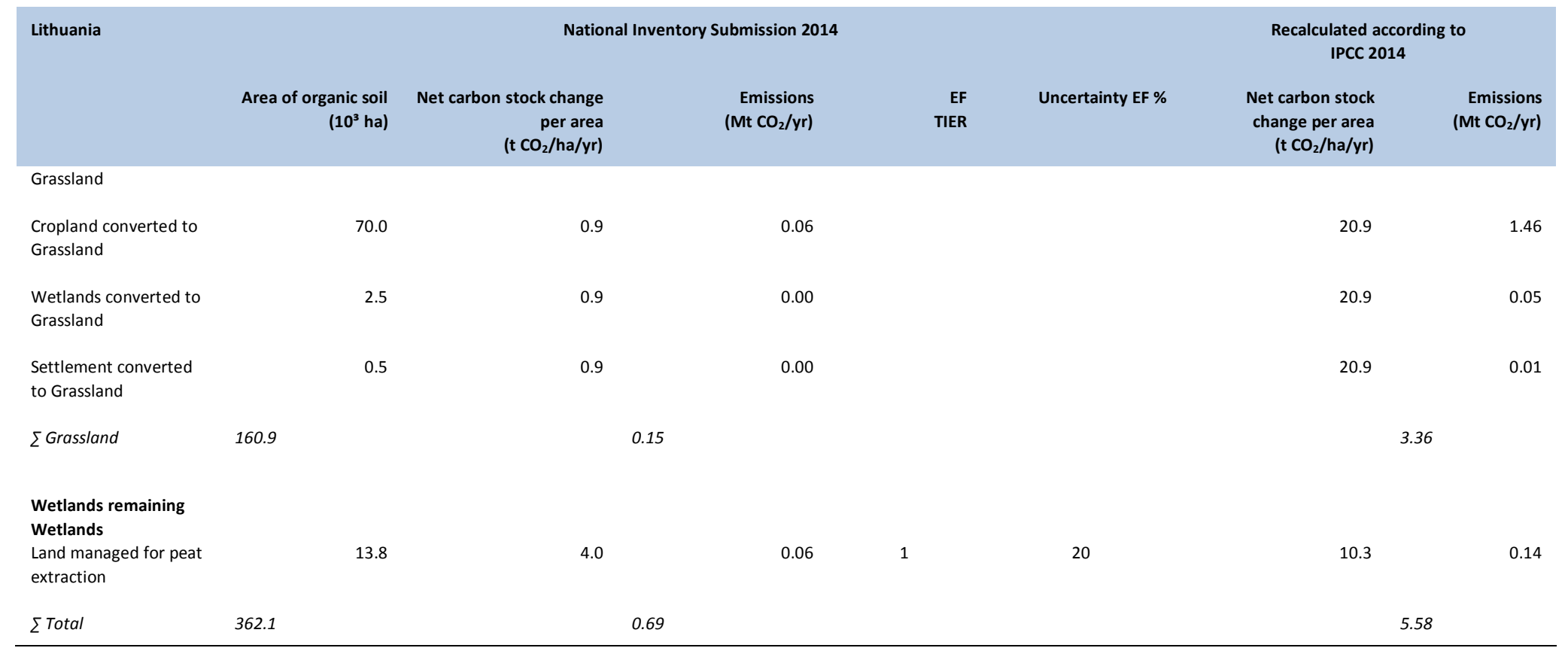

${ }^{1)}$ According to IPCC (2003) Uncertainty Assessment for emission factors. 
Table 7: Area of drained peatlands/organic soils in Lithuania and related emissions (the latter only shown for the Taminskas et al. 2012 data; right column). For emissions of other area estimates (left columns) see Tables 5 and 6. Land use types only correspond to UNFCCC/IPCC land use categories for the data from NIS Lithuania (2014)

\begin{tabular}{|c|c|c|c|c|}
\hline \multirow[t]{2}{*}{ Drainage status and land use type } & \multicolumn{3}{|c|}{ Area per land use type $\left(10^{3} \mathrm{ha}\right)$} & \multirow{2}{*}{$\begin{array}{l}\text { Emissions } \\
\left(\mathrm{Mt} \mathrm{CO}_{2} / \mathrm{yr}\right) \\
\\
\text { tal. }(2012)^{3)}\end{array}$} \\
\hline & NIS Lithuania & Peatland & Taminskas & \\
\hline Undrained peatland, open & & 33.7 & 54.9 & \pm 0 \\
\hline Undrained peatland, forestry & & 28.4 & 123.2 & \pm 0 \\
\hline$\sum$ Subtotal peatland undrained & & 61.5 & 178.1 & \pm 0 \\
\hline Drained peatland, forested & & 115.3 & 162.2 & 1.55 \\
\hline Drained peatland, agriculture & & 269.2 & 283.4 & 5.92 \\
\hline Drained peatland, peat extraction & & 49.7 & 22.3 & 0.23 \\
\hline$\sum$ Subtotal drained peatland & & 434.2 & 467.9 & 7.70 \\
\hline$\sum$ Total peatland & & 495.8 & 646.0 & \\
\hline $\begin{array}{l}\text { Undrained organic soil, Forest } \\
\text { landland }\end{array}$ & 170.4 & & & \\
\hline Drained organic soil, Forest Land & 172.6 & & & \\
\hline Drained organic soil, Cropland & 14.8 & & & \\
\hline Drained organic soil, Grassland & 160.9 & & & \\
\hline $\begin{array}{l}\text { Drained organic soil, } \\
\text { Peat extraction }\end{array}$ & 13.8 & & & \\
\hline$\sum$ Subtotal drained & 362.1 & & & \\
\hline$\sum$ Total organic soil & 532.5 & & & \\
\hline
\end{tabular}

${ }^{1)}$ Applying the Latvian definition: A peatland has $\geq 30 \mathrm{~cm}$ peat if it is undrained and $\geq 20 \mathrm{~cm}$ peat if it is drained (durpynas).

${ }^{2)}$ Dataset "Map of Peatlands and Mires in Lithuania". Not included are $8.2 \times 10^{3}$ ha of undrained and $29.2 \times 10^{3}$ ha of drained areas classified as "Undetermined type of wetland".

${ }^{3)}$ Peatlands are defined as having $\geq 30 \mathrm{~cm}$ peat. Data sources: Soil Database of Lithuania, State Forest Cadastre of Lithuania, Map of Peatlands and Mires in Lithuania (the latter is the basis of our GIS study). 


\subsubsection{Current state of peatland conservation and prospects for peatland restoration}

The research related to peatlands started in Lithuania with the publication of the first list of the "bog flora" from the vicinity of Vilnius (cf. Letukaite et al. 2007). In 1902 Carl Albert Weber published a monograph about "Aukštumala" peatland, which was thus the first scientifically explored European peatland (Weber 1902). This study gives detailed information on the "Aukštumala" area, e.g. on the plant communities and the stratigraphy of the peat layer. Since then, several inventories and scientific studies were carried out by various state institutions and scientific bodies.

All the largest peatlands in Lithuania are protected and included in the Natura 2000 network as an integral part of nature. Lithuania has so far nominated seven sites as Ramsar sites. The peatlands of Lithuania are largely affected by drainage. Large scale restoration projects have been carried out mainly by Lithuanian nature protection NGOs. Generally, it is intended to elaborate management plans for restoration of the protected peatlands. The main restoration goal is to restore or at least improve the hydrological regime. Additional management activities are e.g. shrub removal and regular mowing.

Ecosystematic level goals (E) related to wetlands were fixed in the "Fourth National Report of the Republic of Lithuania to the Convention on Biological Diversity" (200956) as follows:

- conserve wetland ecosystems by prohibiting exploitation of new wetlands, by restoring peatlands, and by delineating measures for the conservation of valuable habitats (E5)

- Conserve natural meadow ecosystems by prohibiting their nontraditional use, by defining

- possibilities for restoring meadows (E6).

Currently, discussion is ongoing about the selection of a drained and degraded peatland area for the development of a demonstration site. At this potential site the relation between peat formation and carbon sequestration could be explained, along with the importance of peatlands as carbon stores. Some regions of Lithuania comprise vast areas of

${ }^{56}$ http://www.cbd.int/d oc/world/lt/lt-nr-04-en.pdf 
abandoned land, including peatlands. The choice of a demonstration site should focus on these regions. Potential sites could be selected on the basis of the existing peatland inventory and the abandoned land inventory of Lithuania (http://www.geoportal.lt/az/). An example from the abandoned land inventory is shown in Figure 5.

Figure 5: Fragment of the abandoned land from the abandoned land inventory. The light red colour indicates abandoned land

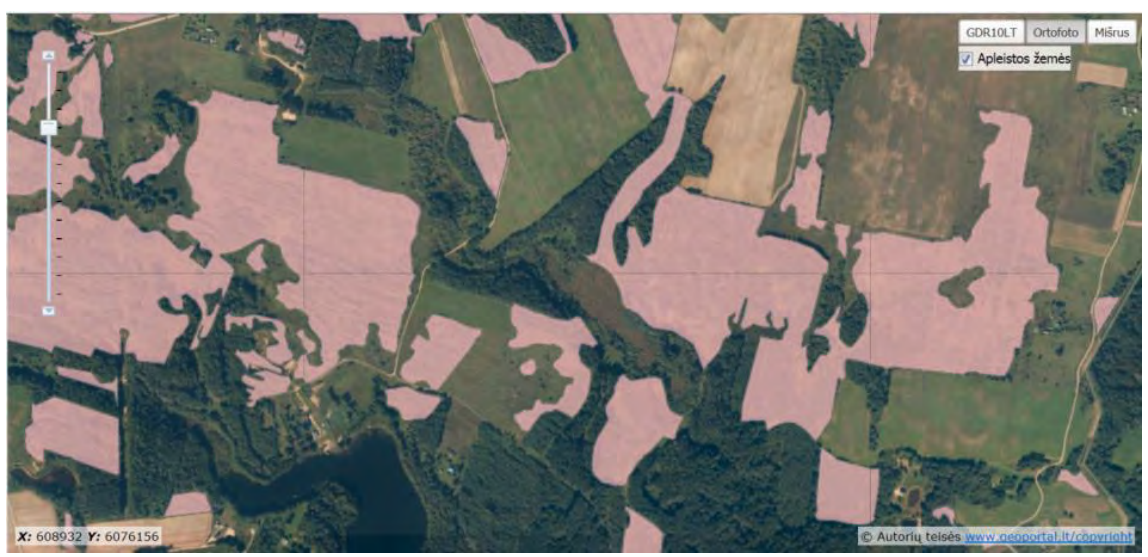

\subsubsection{Acknowledgements}

We thank Dalius Sungaila from the Protected Areas and Landscape Department at the Ministry of Environment of Lithuania for the GIS data preparation and its fast delivery, for the input to Chapter 7.3.5 of this country chapter and more generally for the collaboration to finalize this country assessment.

\subsubsection{References}

Esri ArcGIS World Imagery. Source: Esri, DigitalGlobe, GeoEye, i-cubed, USDA, USGS, AEX, Getmapping, Aerogrid, IGN, IGP, swisstopo, and the GIS User Community. IPCC (2003). Good Practice Guidance for Land Use, and-Use Change and Forestry, Penman J., Gytarsky M., Hiraishi T., Krug T., KrugerD., Pipatti R., Buendia L., Miwa K., Ngara T., Tanabe K. \& Wagner F. (eds.), published by the Institute for Global Environmental Strategies (IGES) for the IPCC, Japan.

IPCC 2014. (2013). Supplement to the 2006 IPCC Guidelines for National Greenhouse Gas Inventories: Wetlands, Hiraishi T., Krug T., Tanabe K., Srivastava N., Baasansuren J., Fukuda M. \& Troxler T.G. (eds), published by IPCC, Switzerland.

Gasiūnienè V. \& Lesiukova N. (2007). Geological and mineral data collection and dissemination in Lithuania. 10-11 December 2007, Ljubljana. Available at: http://www.geozs.si/UserFiles/677/File/TAIEX/20_Vyda\%20Elena\%20Gesiuniene.pdf 
Letukaitė D., Daukantas J. \& Šerstniovaitė I. (2007). Durpiu įmonių asociacija „Lietuviškos durpés" [Annual Report of the Lithuanian Geological Survey].Vilnius, 89 p. (In Lithuanian and English).

Mierauskas P. \& Taminskas J. (2014). Lithuania. In: Joosten H., Tanneberger F. and Moen A. (eds), Mires and peatlands of Europe: Status, distribution, and nature conservation. Schweizerbart Science Publishers, Stuttgart.

Minayeva T., Sirin A., \& Bragg 0. (2009). A quick scan of peatlands in Central and Eastern Europe. Wetlands International, Wetlands International, Wageningen, The Netherlands, $131 \mathrm{p}$.

Morkunaitė R. \& Veitas V. (2011). Cost-benefit analysis effected of the increase of state tax on natural resources for the Lithuanian peat industry and state tax collection. Vilnius: Public Institution Economic Research Center, 15 p. http://www.asocdurpes.lt/ uploads/PDFFiles/20110328_COST\%20BENEFIT\%20ANALYSIS.pdf

Purvinas E. \& Seibutis A. (1957). Pagrindiniai pelkiu rajonai Lietuvos TSR teritorijoje [Main peatland districts in the territory of the Lithuanian SSR]. Academy of Sciences, Series B, LTSR Geologijos ir geografijos institutas, Serija B, 2: 127-140 (In Lithuanian).

Taminskas J., Pileckas M., Šimanauskienė R. \& Linkevičienė R. (2012). Wetland classification and inventory in Lithuania. Baltica 25: 33-44. http://dx.doi.org/10.5200/ baltica.2012.25.03

Weber, C.A. (1902). Über die Vegetation und Entstehung des Hochmoors von Augstumal im Memeldelta, mit vergleichenden Ausblicken auf andere Hochmoore der Erde. P. Parey, Berlin.

Wetlands and peatlands map of Lithuania (2005). Scale 1:200 000. (C) Lithuanian Geological Survey under the Ministry of Environment, 2005 (In Lithuanian). 


\subsection{Finland}

\subsubsection{Characterization of the country}

Figure 1: NorBalWet countries covered in this report (grey); Finland (dark grey)

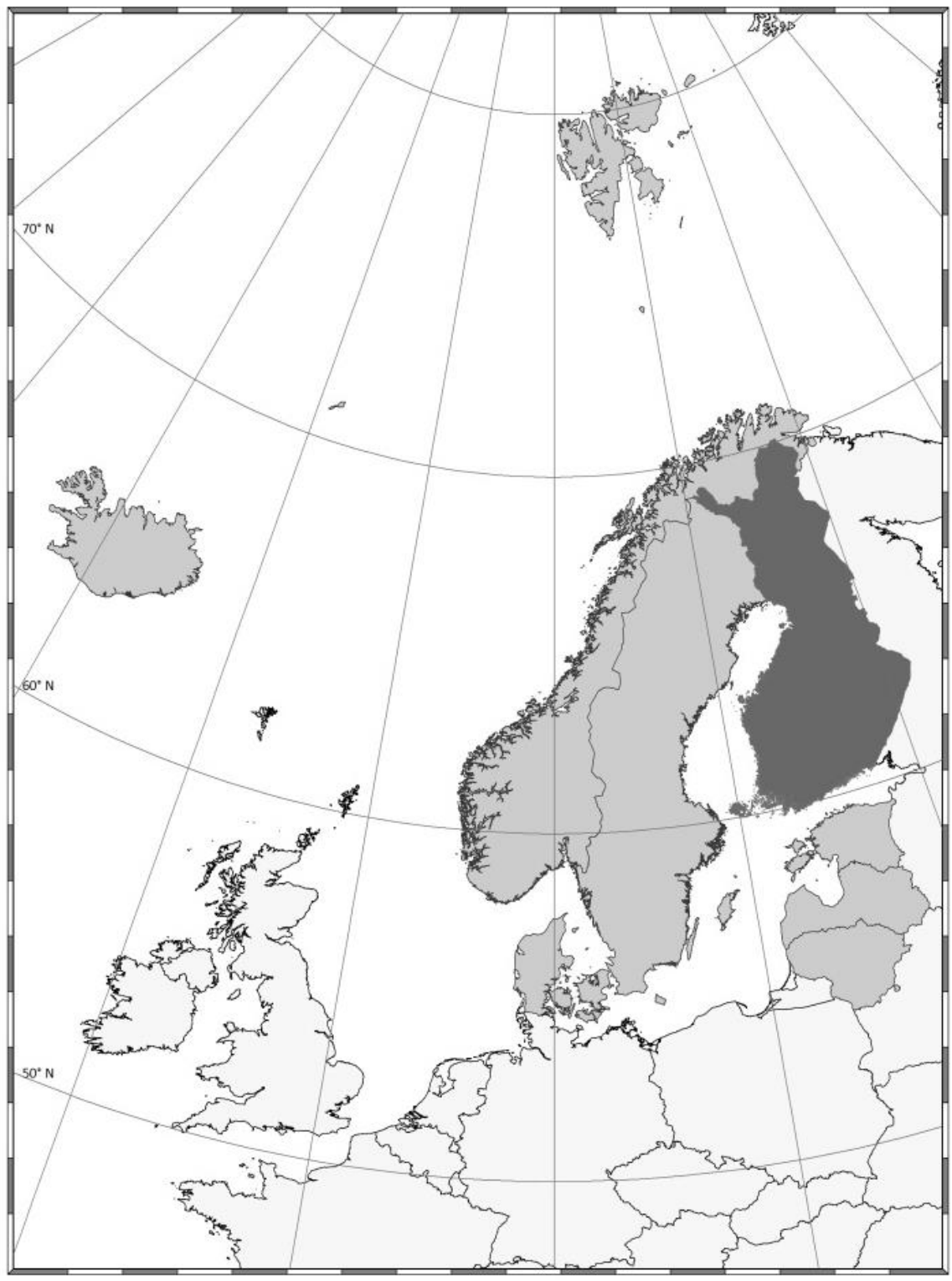


Finland is located in northern Europe between $60^{\circ}$ and $70^{\circ} \mathrm{N}$ and $20^{\circ}$ and $31^{\circ} \mathrm{E}$ (Figure 1). The total area of Finland is $338,000 \mathrm{~km}^{2}$. About 188,000 lakes cover $10 \%$ of the country; forests cover $60 \%$, mires $30 \%$, and cultivated areas and settlements 10\% (Lindholm \& Heikkilä 2015).

The climate in Finland is oceanic-continental, clearly influenced by the Gulfstream. The mean annual temperature varies between $+5.5^{\circ} \mathrm{C}$ in the Southwest and $-2^{\circ} \mathrm{C}$ in the northwest of the country. The warmest month is July (mean temperature 14 to $18^{\circ} \mathrm{C}$ ) and the coldest months are January and February $\left(-4^{\circ} \mathrm{C}\right.$ to $-15^{\circ} \mathrm{C}$; Lindholm \& Heikkilä 2015). The mean annual precipitation varies between $450-500 \mathrm{~mm}$ in the western coast and northern Lapland, and $750 \mathrm{~mm}$ at the southern coast and in the hilly eastern and middle Finland. The mean duration of snow cover on open ground is 110 days in south-western Finland and 220 days in northern Lapland. There is only sporadic permafrost in palsa mires and at the highest treeless fell tops in northern Lapland (Lindholm \& Heikkilä 2015).

\subsubsection{Peatland diversity}

Finland is one of the most peatland rich countries of the world. The general term used for peatlands is "suo". "Suo" includes all places that have peat-forming vegetation, independent of the thickness of the peat layer. In Finland there are seven zones of mire complex types from the South to the North (Lindholm \& Heikkilä 2010). More generally, in the southern part raised bogs are typical, whereas in the North geotrophic aapamires thrive (e.g. Lindholm \& Heikkilä 2006a, Lindholm \& Heikkilä 2010). Due to the large number of mires and mire types in Finland, a variety of descriptors is used (cf. Lindholm \& Heikkilä 2015). Laitinen et al. $(2005,2007)$ developed an eco-hydrological classification system of mires, whereas Lindholm (2013a) recently opened the discussion on the concepts of Finnish mire classification and their use. Major peatland types are concentric bogs, eccentric bogs, aapa mires, palsa mires and orohemiarctic mires (Lindholm \& Heikkilä 2015). Concentric bogs (kilpikeidassuot) can be subdivided into plateau bogs and domed bogs. Plateau bogs (laakiokeidassuot) are typical raised bogs with an elevated centre, which forms an even plateau with an irregular network of hummocks and hollows. Domed bogs (varsinaiset kilpikeidassuot) are domed in shape, with consequently elongated hummocks and hollows surrounding the highest point of the bog in concentric circles (Lindholm \& Heikkilä 2015). In eccentric bogs (viettokeidassuot), hummocks and hollows are arranged in rows perpendicular to the slope. They occur on flat terrain and where rivers and lakes effectively gather the 
spring flood waters (Lindholm \& Heikkilä 2015). Aapa mire (aapasuot) complexes are minerotrophic and have developed under conditions of short summers and long winters with abundant snow, causing high and rather long-lasting spring time floods from the catchment area of the mire (Lindholm \& Heikkilä 2015). Palsa mires (palsasuot) are large peat mounds, up to 7 metres high, containing permafrost. Orohemiarctic mires (tunturi) have developed outside the arctic zone because of the high elevation of northern Fennoscandia fells (Lindholm \& Heikkilä 2015).

\subsubsection{Peatland degradation}

The original maximum extent of all land with peat-forming vegetation (suo) in Finland's was $10,400 \times 10^{3}$ ha, including about 5,000 x $10^{3}$ ha ${ }^{57}$ with a peat layer $>30 \mathrm{~cm}$ in depth (=peatland according to $\S 2.1$; Lindholm \& Heikkilä 2015). Only 3,500 x $10^{3}$ ha of pristine "suo" habitats (mostly in northern Finland) have been left untouched by forestry, agriculture, peat extraction, construction and water engineering. Finland has carried out the world's most extensive programme of draining, mostly for forestry. During the wildest years in the 1970s approximately $300 \times 10^{3}$ ha of peatland was drained annually (Lindholm \& Heikkilä 2015). This has caused a dramatic loss of mire biodiversity (Lindholm \& Heikkilä 2006b). In addition to biodiversity loss, massive drainage of peatlands has also caused remarkable loss of carbon. At the current time, draining of pristine mires has almost ceased and most activities are concentrated on the maintaining of ditches in peatland forests (Lindholm \& Heikkilä 2015).

Most peatland drainage for agriculture took place in the 1950s/1960s. Nowadays, approximately $85 \%$ of the agricultural fields on peatland have been abandoned and some have been converted to forests. $6.5 \times 10^{3}$ ha of mire areas have been flooded, mainly for water reservoirs (NIS Finland 2014).

57 Only includes sites larger than 20 ha. 


\subsubsection{Current peatland: location, extent, status, land use and greenhouse gas emissions}

\section{Material and Methods}

To assess the location and extent of peatlands we used

- the raster GIS dataset "peatlands of Finland", which separates drained and undrained peatlands in a grid of $25 \mathrm{~m}$ x $25 \mathrm{~m}$. Peatlands are classified as "drained", if they are less than $50 \mathrm{~m}$ away from a maximally $5 \mathrm{~m}$ wide, flowing water body. Furthermore, peat extraction sites are indicated.

To estimate the area and emissions from drained and used peatlands, we used

- the recent National Inventory Submission of Finland to the United Nations Framework Convention on Climate Change (NIS ${ }^{58}$ Finland 2014).

In the National Inventory Submission for Finland (NIS Finland 2014), reported areas of drained organic soil are derived from the National Forest Inventory (NFI) and the geo-referenced Finnish soil database. The NFI is a sampling-based forest inventory system, which is adapted to the spatial variation of the forests and the density of the road network across Finland. The 11th inventory was launched in 2009 and the field measurements were completed in 2013. The Finnish soil database includes a soil map and properties of the soil (scale 1:250,000) elaborated by Agrifood Research Finland, the Finnish Forest Research Institute and the Geological Survey of Finland. In the database polygons $<6.25$ ha are merged with adjacent larger polygons. The soil database was used for reporting area of organic soil on Cropland and partly Grassland (NIS Finland 2014).

\footnotetext{
58 The National Inventory Submission ("NIS") consists of the National Inventory Report ("NIR") and the Common Reporting Format ("CRF"). Since both the NIR and the CRF were used, we will further refer to the complete National Inventory Submission of Finland (NIS Finland 2014).
} 
To address utilization pressure and threat of peatland types and mire habitats across Finland, we used

- the "Assessment of threatened mire habitats in Finland" (Kaakinen et al. 2012). ${ }^{9}$

For error analysis of the dataset "peatlands of Finland" (see above), we visually checked the accuracy of the peatland borders against open layer satellite images of Google Earth, Bing and OpenCycleMap OCM (http://www.opencyclemap.org/) for 5 randomly selected areas with a diameter of $10 \mathrm{~km}$. This analysis showed that extensive open peatlands are mostly correctly indicated, but that borders and location of smaller and forested peatlands are often incorrect. The dataset classifies peatlands as "drained" if they are less than $50 \mathrm{~m}$ away from ditches. Since often a distance of $200 \mathrm{~m}$ is used to define the impact zone of peatland drainage (e.g. NIS Iceland 2014), the area of drained peatlands in Finland might be larger than the dataset "peatlands of Finland" indicates.

A detailed inventory of peatland types and drainage status is needed to identify threatened peatland types and emission hotspots spatially explicitly and to plan and implement protection and restoration activities. Some detailed surveys have been done e.g. by the Geological Survey of Finland, but none of them covers Finland totally or for a major part.

We used the IPCC (2014) Tier 1 default emission factors for $\mathrm{CO}_{2}$ for the Boreal climate/vegetation zone to recalculate the emissions reported in the NIS Finland (2014) for Cropland and Grassland. (Table 1, 3).

\begin{tabular}{|c|c|c|}
\hline IPCC category & NIS Finland (2014) & IPCC (2014) \\
\hline Cropland remaining Cropland & 18.4 & 29.0 \\
\hline Forest Land converted to Cropland & 18.9 & 29.0 \\
\hline Grassland & 11.7 & $20.9^{1)}$ \\
\hline
\end{tabular}

\footnotetext{
${ }^{1)}$ Deeply drained: average of EF “Grassland, drained, nutrient-poor" and "Grassland, deep-drained,
} nutrient-rich" (excl. EF "Grassland, shallow drained, nutrient-rich" from IPCC 2014).

The Tier 1 default emission factors from IPCC (2014) are based on a meta-analysis of available data (including the sources cited in the NIS

59 http://www.environment.fi/treatenedhabitattypes 
Finland 2014) and did not find a significant difference between boreal and temperate Cropland and Grassland on organic soil. For this metaanalysis several Finnish data were corrected for biomass removal. The values given by Maljanen et al. (2007) and used in the NIS Finland (2014) erroneously did not do so.

We did not include Carbon loss by DOC (Dissolved Organic Carbon.

Peat carbon stock values were derived from Virtanen \& Valpola (2011).

\section{Results}

The GIS dataset "peatlands of Finland" shows that peatlands in Finland cover in total 8,319.8 $\times 10^{3}$ ha, including $4,799.8 \times 10^{3}$ ha of drained peatlands (Table 2). Although the data have some limitations and areas are probably not exactly correct (see the results of NIS Finland 2014; Table 3), the data give a very good picture of the state of mires in Finland. The majority of peatlands is located in central and northern Finland, where larger areas are still undrained. Peatlands of southern Finland are almost all drained and intensively used (Figure 2).

\begin{tabular}{|c|c|c|c|c|c|}
\hline & Total & & ained & & Drained \\
\hline & (10 $\left.0^{3} \mathrm{ha}\right)$ & (10 $10^{3}$ a) & $\%$ & (10 $\left.10^{3} \mathrm{ha}\right)$ & $\%$ \\
\hline Peatland area & $8,319.8$ & $3,519.9$ & 42.3 & $4,799.8$ & 57.7 \\
\hline
\end{tabular}

In the National Inventory Report (2014) Finland reported 5,969.1 x $10^{3}$ ha of Forest Land on drained organic soil, $338.5 \times 10^{3}$ ha of Cropland on drained organic soil, $73.1 \times 10^{3}$ ha of Grassland on drained organic soil, $112.3 \times 10^{3}$ ha of organic soil drained for Peat extraction and $6.5 \times 10^{3}$ ha flooded organic soils (Table 3). Drainage and land use lead, according to the NIS Finland (2014), to an annual peatland $\mathrm{CO}_{2}$ emission of 16.4 Mt. These emissions recalculated on the basis of the latest Tier 1 default emission factors (IPCC 2014) for Cropland and Grassland arrive at an annual emission of $9.81 \mathrm{Mt} \mathrm{CO}_{2}$ for Cropland and of $1.53 \mathrm{Mt} \mathrm{CO}_{2}$ for Grassland, which leads to total emissions from drained organic soils of $20.7 \mathrm{Mt} \mathrm{CO}_{2}$ annually (Table 3 ). 
Figure 2: Undrained peatlands, drained peatlands and peat extraction areas of Finland (unchanged GIS dataset "peatlands of Finland", see Material and Methods above)

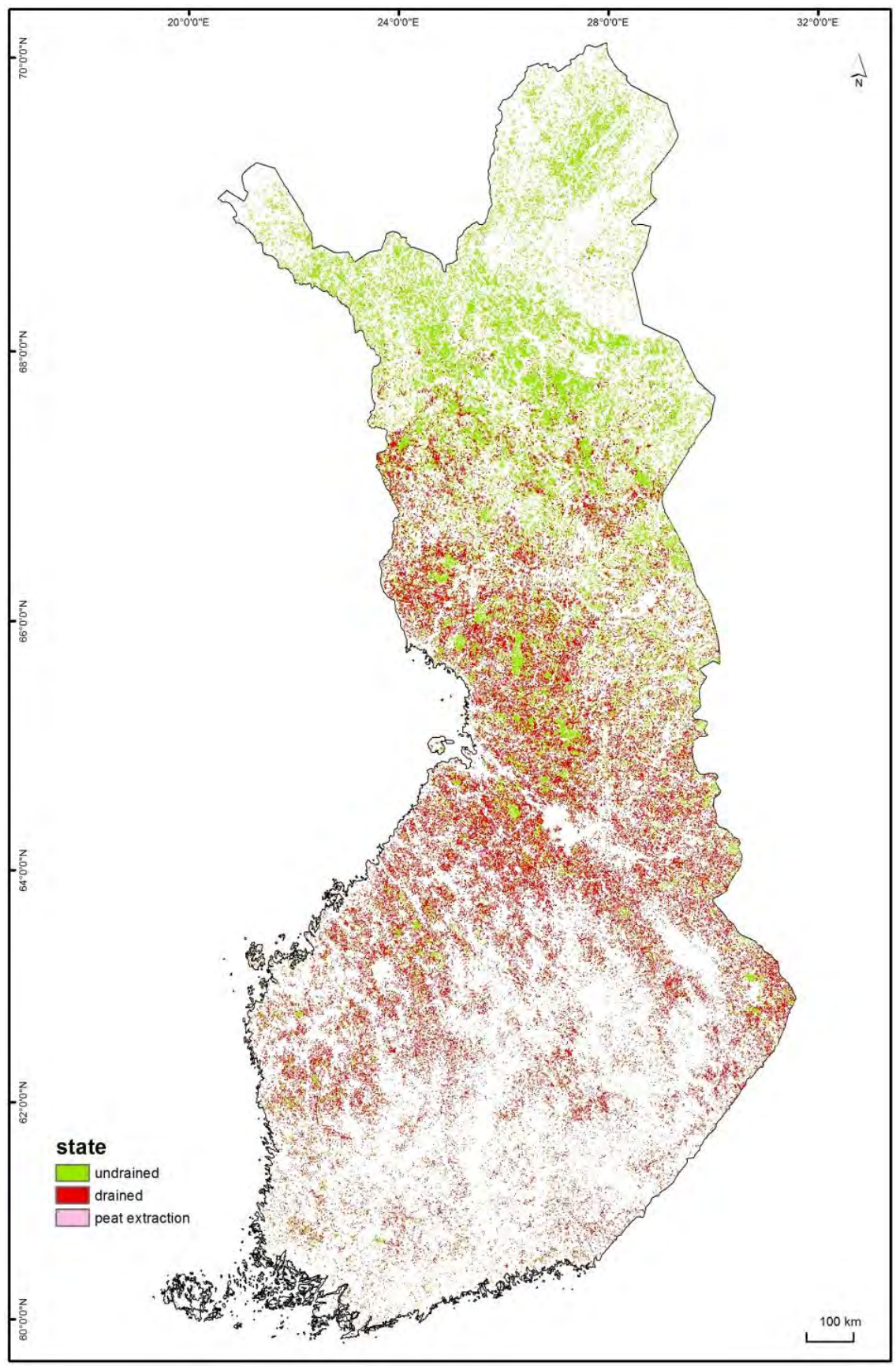


Table 3: Drained organic soil areas, land use types and associated $\mathrm{CO}_{2}$ emissions. Left part of the table: as reported in the National Inventory Report of Finland (2014) to the UNFCCC. Right part: recalculation of emissions with the new IPCC (2014) default emission factors for $\mathrm{CO}_{2}$

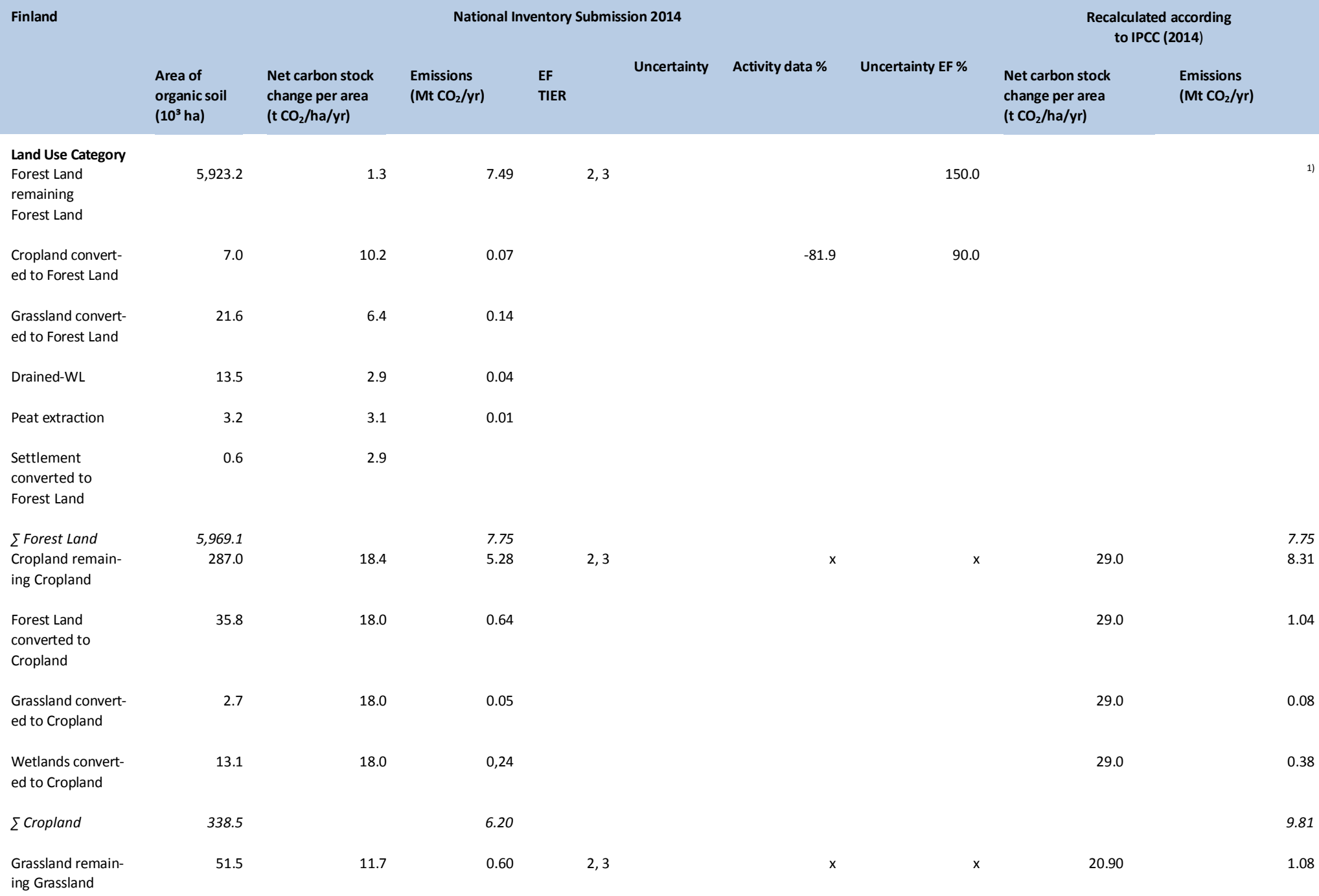




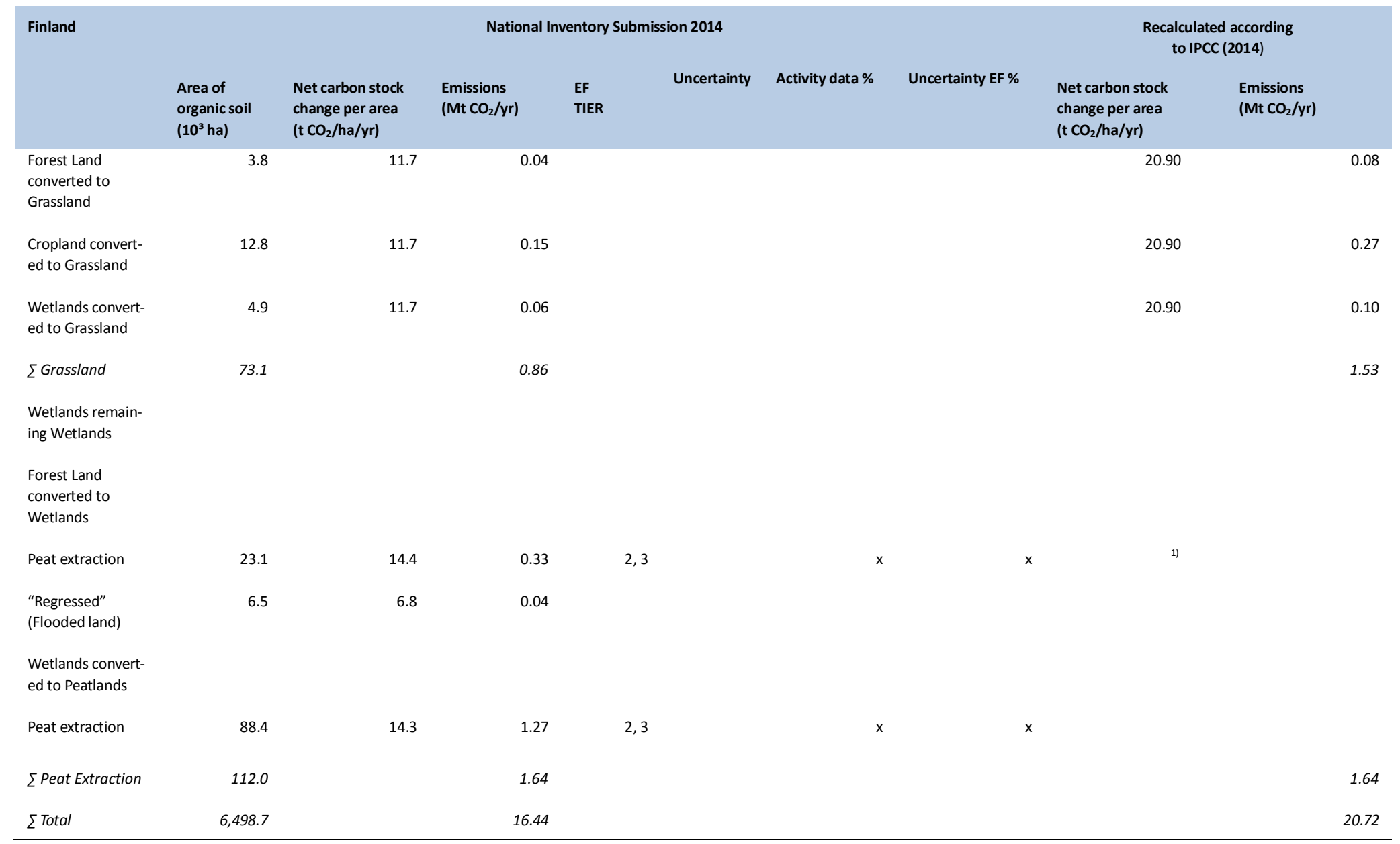

1) National emission factors are more differentiated than and/or close to the Tier 1 IPCC (2014) emission factors. Thus, emissions for Forest Land and Peat extraction were not recalculated. 
Kaakinen et al. (2012) found, by using a combination of "different kind of GIS data" (see also: http://www.environment.fi/treatenedhabitattypes), that mire loss and peatland degradation is caused by drainage for forestry, agriculture, construction (e.g. towns, rural areas, and roads), water engineering (e.g. hydropower stations, mill dams, harbours, waterways) and peat extraction. Drainage has been most intensive in southern Finland, but also quite intensive in the southern parts of the northern Boreal vegetation zone. Thus, the proportion of the Red List Categories in the main mire site type groups is considerably larger in southern Finland (Figure 3 a) than in northern Finland (Figure 3b).

Figure 3: The proportion of the Red List Categories in the main mire site type groups in (a) southern and (b) northern Finland. Mire site type groups: $S=$ spruce mires, $S F=$ spruce-birch fens and rich spruce-birch fens, $P=$ pine mires and bogs, $P F=$ pine fens and rich pine fens, $F=f e n s, R F=$ rich fens, $S W=$ swamps, $n=$ the number of site types assessed (from Kaakinen et al. 2012)
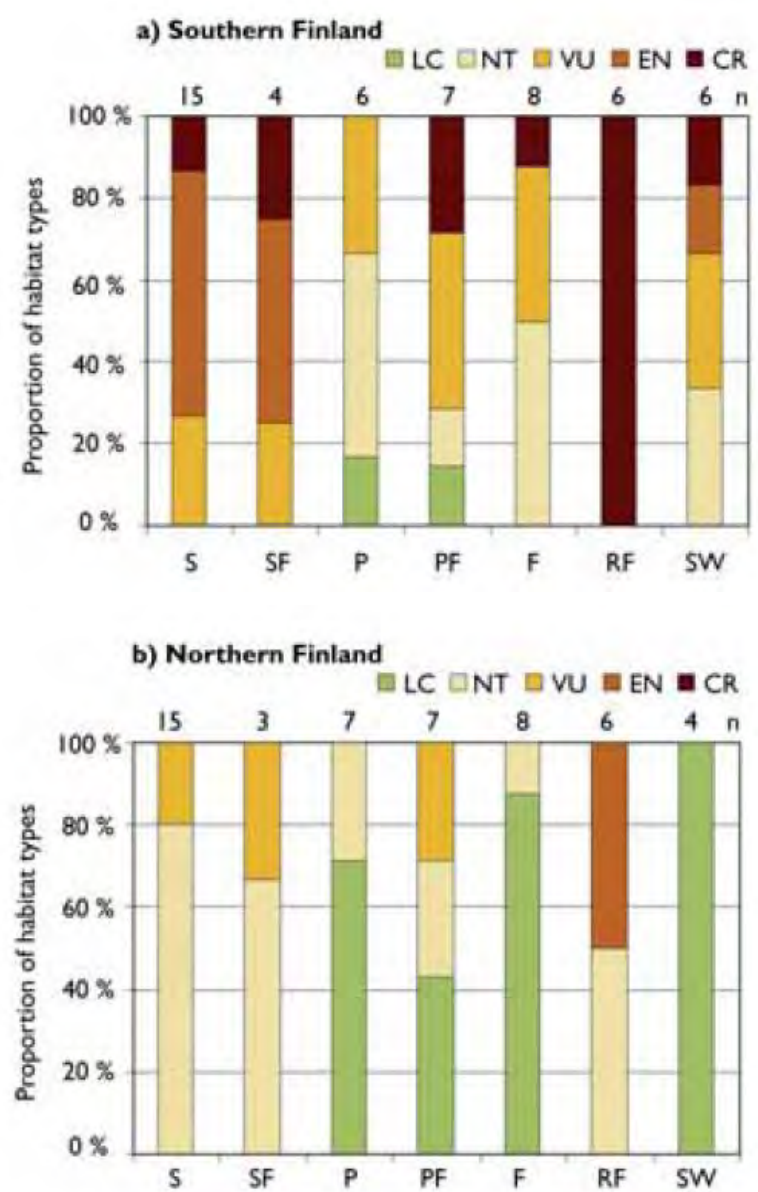
The proportion of threatened mire site types is highest among rich fens, spruce mires, spruce-birch fens and rich spruce-birch fens (Table 4). Also some of the swamp site types on the land uplift coast around the Gulf of Bothnia ${ }^{60}$ belong to the most threatened mire site types. In the whole country, the category LC (least concern) typically applies to the still quite common, poorest and wettest mire site types, which occur throughout the country or are concentrated in northern Finland.

According to Virtanen and Valpola (2011), the mean depth of peatlands is $1.41 \mathrm{~m}$ and the thickest peat layer found is $12.3 \mathrm{~m}$. The national peat reserve (i.e. in peatlands larger than 20 hectares) totals $69.3 \times 10^{9}$ $\mathrm{m}^{3}$ in situ of which the largest amount occurs in northern Finland. The dry solids of peat are estimated at 6.300 Mt tons. Sphagnum peat accounts for $54 \%$ and Carex peat for $45 \%$ to these peat reserves.

Peatlands that are technically suitable for peat extraction cover an area of $1,200 \times 10^{3}$ ha and contain $29.6 \times 10^{9} \mathrm{~m}^{3}$ of peat in situ. Slightly humified peat suitable for horticultural and environmental use totals 5.9 $\mathrm{x} 10^{9} \mathrm{~m}^{3}$ in situ. The energy peat reserve is $23.7 \times 10^{9} \mathrm{~m}^{3}$ in situ and its energy content amounts to 12,800 TWh (Virtanen \& Valpola 2011).

\begin{tabular}{|c|c|c|c|}
\hline \multirow[t]{2}{*}{ Habitat Type } & \multicolumn{3}{|c|}{ Red List Category } \\
\hline & South Finland & North Finland & Total Finland \\
\hline \multicolumn{4}{|l|}{ Herb-rich spruce mires } \\
\hline Fern spruce mires & EN & NT & VU \\
\hline Herb and grass spruce mires & EN & NT & VU \\
\hline Spring spruce mires & EN & NT & VU \\
\hline $\begin{array}{l}\text { Herb-rich Vaccinium myrtillus spruce } \\
\text { mires }\end{array}$ & NT & EN & VU \\
\hline \multicolumn{4}{|l|}{ Dwarf shrub spruce mires } \\
\hline $\begin{array}{l}\text { Vaccinium myrtillus } \\
\text { spruce mires }\end{array}$ & VU & NT & VU \\
\hline Equisetum sylvaticum spruce mires & EN & VU & EN \\
\hline Vaccinium vitis-idaea spruce mires & VU & NT & VU \\
\hline Rubus chamaemorus spruce mires & VU & NT & VU \\
\hline
\end{tabular}

${ }^{60}$ For more information see: http://www.fgi.fi/fgi/themes/land-uplift 


\begin{tabular}{|c|c|c|c|}
\hline \multirow[t]{2}{*}{ Habitat Type } & \multicolumn{3}{|c|}{ Red List Category } \\
\hline & South Finland & North Finland & Total Finland \\
\hline \multicolumn{4}{|c|}{ Spruce-Birch fens and rich Spruce-Birch fens } \\
\hline Rich spruce-birch fens & & VU & VU \\
\hline Tall-sedge spruce-birch fens & VU & NT & NT \\
\hline Carex nigra birch fens & EN & / & EN \\
\hline Eriophorum vaginatum birch fens & EN & NT & EN \\
\hline \multicolumn{4}{|l|}{ Pine mires and bogs } \\
\hline Spruce-pine mires & VU & NT & VU \\
\hline Carex globularis pine mires & Vu & LC & NT \\
\hline \multicolumn{4}{|l|}{ Pine fens and rich Pine fens } \\
\hline Rich pine fens & & VU & VU \\
\hline Herb rich pine fens & & VU & VU \\
\hline Tall-sedge pine fens & VU & LC & LC \\
\hline Sphagnum papillosum pine fens & VU & NT & VU \\
\hline Low-sedge pine fens & VU & NT & NT \\
\hline \multicolumn{4}{|l|}{ Fens } \\
\hline Herb rich sedge fens & & NT & VU \\
\hline Tall-sedge fens & Vu & LC & LC \\
\hline Sphagnum papillosum fens & VU & LC & NT \\
\hline Minerotrophic low-sedge fens & VU & LC & $\mathrm{LC}$ \\
\hline \multicolumn{4}{|l|}{ Rich fens } \\
\hline Rich swamp fens & & EN & EN \\
\hline Rich spring fens & & NT & VU \\
\hline Rich birch flark fens & & NT & VU \\
\hline Rich birch lawn fens & & EN & \\
\hline Rich lawn fens & & EN & EN \\
\hline Rich flark fens & & NT & NT \\
\hline \multicolumn{4}{|l|}{ Swamps } \\
\hline Birch swamps & VU & $\mathrm{LC}$ & NT \\
\hline Alnus incana swamps & & / & \\
\hline Myrica gale swamps & EN & / & EN \\
\hline
\end{tabular}




\begin{tabular}{|c|c|c|c|}
\hline \multirow[t]{2}{*}{ Habitat Type } & \multicolumn{3}{|c|}{ Red List Category } \\
\hline & South Finland & North Finland & Total Finland \\
\hline \multicolumn{4}{|l|}{ Spruce mires $^{1)}$} \\
\hline Thin-peated herb spruce mires ${ }^{1)}$ & EN & NT & EN \\
\hline $\begin{array}{l}\text { Thin-peated Vaccinium myrtillus } \\
\text { spruce mires }{ }^{1)}\end{array}$ & VU & NT & VU \\
\hline $\begin{array}{l}\text { Thin-peated Vaccinium vitis-idaea } \\
\text { spruce mires }{ }^{1)}\end{array}$ & EN & NT & VU \\
\hline Thin-peated rich fern spruce mires ${ }^{1)}$ & EN & NT & VU \\
\hline $\begin{array}{l}\text { Thin-peated rich herb-grass spruce } \\
\text { mires }{ }^{1)}\end{array}$ & EN & NT & VU \\
\hline Thin-peated rich fen spruce mires ${ }^{1)}$ & & vu & EN \\
\hline Thin-peated rich spring spruce mires ${ }^{1)}$ & & Vu & EN \\
\hline \multicolumn{4}{|l|}{ Mire Habitat Complexes } \\
\hline \multicolumn{4}{|l|}{ Raised Bogs } \\
\hline Wooded raised bogs & EN & / & EN \\
\hline Southern eccentric raised bogs & VU & / & VU \\
\hline Sphagnum fuscum raised bogs & Vu & LC & VU \\
\hline \multicolumn{4}{|l|}{ Aapa mires } \\
\hline $\begin{array}{l}\text { Middle boreal lawn-surfaced aapa } \\
\text { mires }\end{array}$ & EN & / & EN \\
\hline $\begin{array}{l}\text { Middle boreal flark-surfaced aapa } \\
\text { mires }\end{array}$ & Vu & NT & VU \\
\hline Middle boreal sloping fens & VU & LC & NT \\
\hline \multicolumn{4}{|l|}{ Mire sucession series on the uplift coast } \\
\hline $\begin{array}{l}\text { Raised bog succession series of the } \\
\text { land uplift coast }\end{array}$ & & / & \\
\hline $\begin{array}{l}\text { Aapa mire succession series of the } \\
\text { land uplift coast }\end{array}$ & & / & \\
\hline
\end{tabular}

${ }^{1)}$ This group may not meet peatland criterion: peat layer $>30 \mathrm{~cm}$ thick.

\section{Discussion and Outlook}

In order to review the importance of peatlands in Finland for climate change mitigation and the potentials for restoration, we used and integrated a variety of geospatial and other data.

The geospatially explicit dataset "peatlands of Finland" does not differentiate between ecological or hydrogenetic peatland types - their extent could not be assessed. Furthermore, appropriate GIS land use data were missing, since the available Corine land use data are of very low resolution and do not include data on areas drained for forestry and agriculture. Thus, with the "peatlands of Finland" GIS data the land use 
types could not be assessed, which would be necessary for calculate the emissions from peatlands. Other, better geospatial peatland data that cover the entire country do not yet exist, but data being collected by e.g. the Finnish Geological Survey will in future provide a better basis for emission assessment.61

To estimate the importance of peatlands regarding the mitigation of climate change, we used the area and emission data of drained organic soils as reported in the National Inventory Report of Finland to the UNFCCC (NIS Finland 2014). The area data for drained and used organic soils of NIS Finland (2014) were adopted unchanged, but the application of the IPCC (2014) Tier 1 default emission factors for Cropland and Grassland (instead of the national emission factors from Finland (Table 1 in Material and Methods above resulted in an increase in $\mathrm{CO}_{2}$ (Table 3).

To identify promising peatlands for emission reduction, restoration or as new Ramsar sites, it might be beneficial to analyse the GIS dataset and data background of Kaakinen et al. (2012).

\subsubsection{Potential for conservation, restoration and establishing demonstrations sites}

In Finland, there is a high potential for designating Ramsar sites that contribute to reduction of $\mathrm{CO}_{2}$ emission globally and can be used as educative examples of the underlying processes. There are many peatlands to choose from, both hydrologically intact and protected peatlands that serve as carbon storage, and those that have been drained and emit greenhouse gases. Even within the conservation area network there are peatlands that need partial restoration for improving their hydrological status, and at the same time turning the carbon flux from emitting to neutral or positive.

Also among the existing Finnish peatland Ramsar sites there are a number of potential sites to demonstrate carbon fluxes from pristine vs. drained peatlands, and how these fluxes can be influenced by rewetting for restoration. All these sites have visitor centres or field information sheets, where information about the carbon fluxes and other ecosystem services can easily be disseminated. Further, 11 new Ramsar sites are in process to be designated in 2015, including a number of potential

\footnotetext{
61 http://www.gtk.fi/index.html; http://gtkdata.gtk.fi/Turvevarojen_tilinpito/index.html; http://www.geofoorumi.fi/20101/sivu7.html
} 
demonstration sites. Finland will fully explore the possibilities of designating demonstrating sites for the carbon storage and flux of peatlands, either by updating the Ramsar site Information Sheets (RIS62) of the existing sites or during the designation process of the new sites.

There are current and planned projects that aim for finding costefficient and ecologically beneficial restoration methods at the catchment level scale. For example, a national strategy for the prioritization for restoration of Finnish ecosystems towards reaching the Convention of Biological Diversity (CBD63) and EU 15\% target for restoration of degraded ecosystems is in process (Target 2 of the EU 2020 EU Biodiversity Targets ${ }^{64}$ ). This strategy aims at a national prioritization model between and within ecosystem types (e.g. forests vs. mires, and between mire types). Meanwhile, targets for peatland restoration in conservation areas are set annually. Currently, the focus is shifting towards improving the hydrological coherence of mire entities within the conservation areas by restoring the drained edges of valuable mires, and by protecting the most valuable edges that are still outside the conservation area network. A complementary mire conservation programme is under preparation.

\subsubsection{Acknowledgements}

We thank Jari Ilmonen for the review of this Finish country chapter, the input for Chapter 7.4.5 of this country chapter and the prompt GIS data delivery.

\subsubsection{References}

IPCC 2014. (2013) Supplement to the 2006 IPCC Guidelines for National Greenhouse Gas Inventories: Wetlands, Hiraishi T., Krug T., Tanabe K., Srivastava N., Baasansuren J., Fukuda M. \& Troxler, T.G. (eds), Published by IPCC, Switzerland.

Kaakinen E., Kokko A. \& Aapala, K. (2012). Assessment of threatened mire habitats in Finland. In: Lindholm, T. \& Heikkilä, R. (eds.), Mires from pole to pole. The Finnish Environment 38: 181-195, Edita Prima Oy, Helsinki, Finland.

Heikkilä R. \& Lindholm T. (2008). Soidensuojelun vaikeat vuosikymmenet [The difficult decades of mire protection in Finland]. Terra 120: 95-106 (In Finnish).

\footnotetext{
${ }^{62}$ http://www.ramsar.org/sites/default/files/documents/pdf/cop11/res/cop11-res08-e-anx1.pdf https://rsis.ramsar.org/about

$63 \mathrm{http}: / /$ www.cbd.int/

${ }^{64} \mathrm{http}: / /$ www.cbd.int/nbsap/about/targets/eu/
} 
Laitinen J., Rehell S. \& Huttunen A. (2005). Vegetation-related hydrotopographic and hydrologic classification for aapa mires (Hirvisuo, Finland). Annales Botanici Fennici 42: 107-121.

Laitinen J., Rehell S., Huttunen A, Tahvanainen T., Heikkilä R. \& Lindholm, T. (2007). Mire systems in Finland - special view to aapa mires and their water-flow pattern. Suo 57: 1-26.

Lappalainen E. \& Hänninen, P. (1993). Suomen turvevarat. [The peat reserves of Finland]. GeologicaLSurvey of Finland. Report of Investigation 117: 1-118 (In Finnish)

Lindholm T. \& Heikkilä R. (2005). Mires in Finland, their Utilization and Conservation. Stapfia 85, (Kataloge der Ober-Österreichischen Landesmuseen), Neue Serie 35: 233-246 (available at: www.biologiezentrum.at).

Lindholm T. \& Heikkilä R. (2006a). Geobotany of Finnish forests and mires: the Finnish approach. In: Lindholm T. \& Heikkilä R. (eds.), Finland - land of mires. The Finnish Environment 23: 95-103.

Lindholm T. \& Heikkilä R. (2006b). Destruction of mires in Finland. In: Lindholm T. \& Heikkilä R. (eds.), Finland - land of mires. Helsinki, Finnish Environment Institute. The Finnish Environment 23: 179-192.

Lindholm T. \& Heikkilä R. 2010. The Finnish concept of vegetation and zones of natural forests and mires. In: Talbot S., Charron T. \& Barry, T. (eds.), Proceedings of the Fifth International Workshop on Conservation of Arctic Flora and Fauna (CAFF) Flora Group. Circumboreal Vegetation Mapping (CBVM) Workshop, Helsinki, Finland, November 36th, 2008. CAFF. International Secretariat, CAFF Flora Expert Group (CFG), CAFF Technical Report No. 21: 106-111.

Lindholm T. (2013a). Onko suomalainen suoluokittelu oppinsa vanki? [Does the Finnish mire classification system restrict oneself within its doctrine?]. Suo 64: 2942 (In Finnish).

Lindholm T. (2013b). Miten käsityksemme suoyhdistymistä syntyi, kehittyi ja muovasi näkemyksmme Suomen soista - Sata vuotta A. K. Cajanderin suoklassikosta: Studien über die Moore Finnlands. Suo 64: 119-134 (In Finnish).

Lindholm T. \& Heikkilä R. (2015). Finland. In: Joosten H., Tanneberger F. and Moen A. (eds.), Mires and peatlands of Europe: Status, distribution, and nature conservation. Schweizerbart Science Publishers, Stuttgart.

Maljanen M., Hytönen J., Mäkiranta P., Alm J., Minkkinen K., Laine J. \& Martikainen P.J. (2007). Greenhouse gas emissions from cultivated and abandoned organic croplands in Finland. Boreal Environment Research 12: 133-140.

NIS Finland (2014). Greenhouse gas emissions in Finland 1990-2012. National Inventory Report under the UNFCCC and the Kyoto Protocol, 471 p. + Annexes. Available at: https://unfccc.int/national_reports/annex_i_ghg_inventories/national_inventories_su bmissions/items/8108.php.

Virtanen K. \& Valpola S. (2011). Energy potential of Finnish peatlands. Geological Survey of Finland, Special Paper 49: 153-161. 


\subsection{Sweden}

\subsubsection{Characterization of the country}

Figure 1: NorBalWet countries covered in this report (grey); Sweden (dark grey)

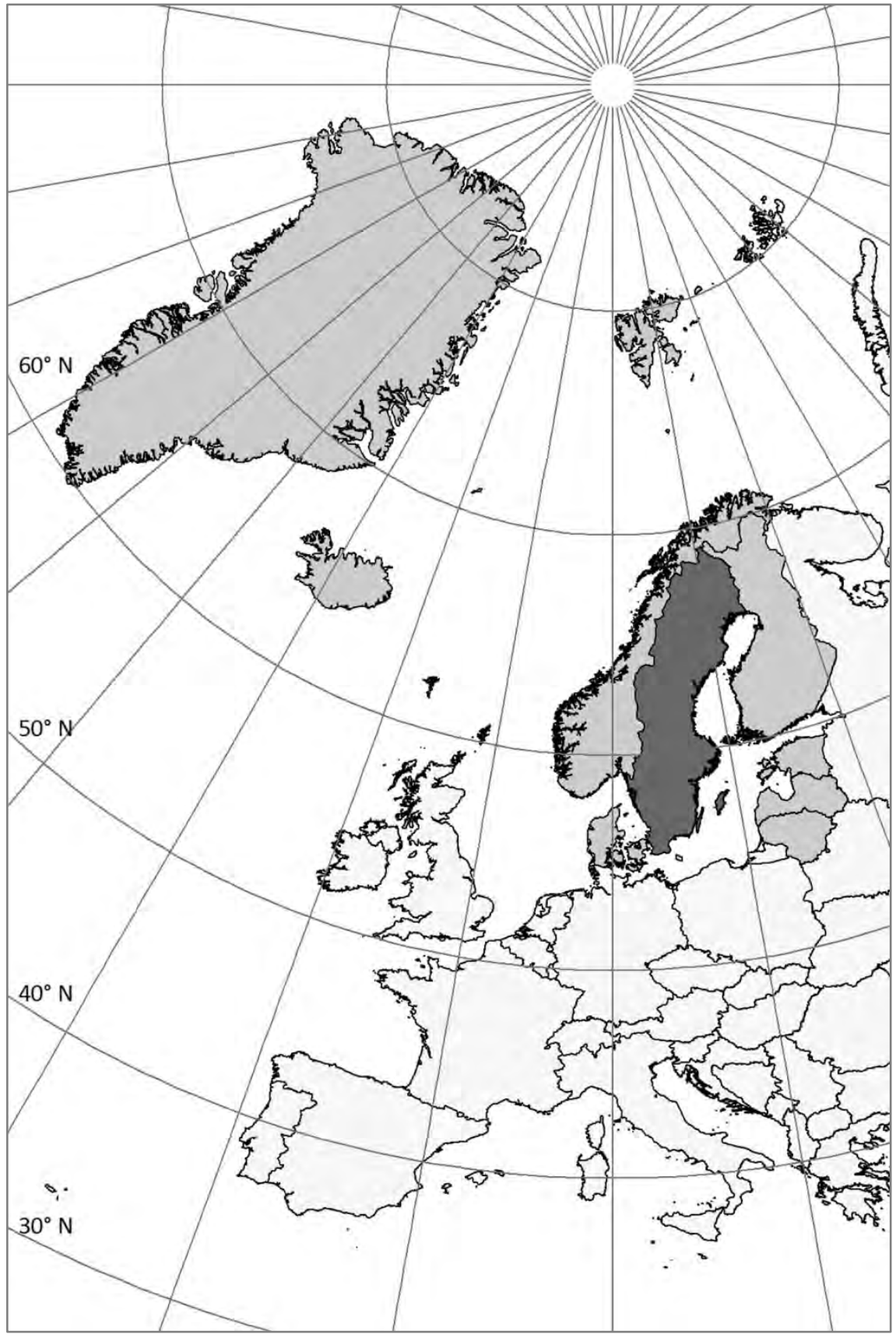


Sweden is situated in northern Europe, West of the Baltic Sea. The land area covers about $40,730 \times 10^{3}$ ha (SCB 2013a; Figure 1). The country stretches 1,572 km from North to South (Lantmäteriet et al. 2013) and the landscape changes considerably with latitude and altitude. Geologically, Sweden predominantly belongs to the Fennoscandian shield. The old preCambrian bedrock is exposed in many places. Younger bedrock (mostly Cambro-Silurian) exists in some regions, e.g. in parts of Jämtland and on the Islands Öland and Gotland.65 The thickness of the soil layers varies over the country, from non-existent or thin to several metres deep (Fredén 1998). Sweden has favourable natural conditions for wetland development (e.g. innumerable depressions), and wetlands cover about $23 \%$ of the land area. Especially the North of Sweden hosts large areas of mires.

A large part of the country is situated in the Boreal and Boreonemoral climate/vegetation zone. The Alpine climate/vegetation zone of the northwest runs along the Norwegian border to Sweden. The South of the country belongs, according to the Nordiska ministerrådet (1977), to the Nemoral climate/vegetation zone. In the climate classification of the Intergovernmental Panel on Climate Change (IPCC), 66 a large part of Sweden belongs to the "Cool Temperate, Moist" climate zone.67 The mean annual precipitation is $700 \mathrm{~mm}$, with most rain in the southwest and in exposed parts of the alpine zone. The driest areas of Sweden are in the lowlands of the very North, and in the East. 68 The mean January temperature is about $0 \mathrm{C}$ in the South and $-15 \mathrm{C}$ in the North; the mean July temperature is about $17^{\circ} \mathrm{C}$ and $13^{\circ} \mathrm{C}$, respectively. ${ }^{69}$

\footnotetext{
65 http://www.sgu.se/en/geology-of-sweden/the-bedrock-of-sweden/

66 http://www.ipcc.ch/

67 http://eusoils.jrc.ec.europa.eu/projects/RenewableEnergy/

$68 \mathrm{http}: / /$ www.smhi.se/kunskapsbanken/meteorologi/nederbord-1.361

${ }^{69}$ http://www.smhi.se/kunskapsbanken/meteorologi/temperatur-1.3843
} 


\subsubsection{Wetland and peatland diversity}

\begin{tabular}{|c|c|c|}
\hline \multirow[b]{2}{*}{ Aggregated myr types } & \multicolumn{2}{|c|}{ Area } \\
\hline & $10^{3}$ ha & $\%$ \\
\hline Raised bogs & 172.2 & 3.3 \\
\hline Plane - slightly raised bogs & 225.9 & 4.4 \\
\hline Northern bog & 153.6 & 3.0 \\
\hline Topogenous fens & $1,131.1$ & 21.9 \\
\hline Soligenous fens & 566.7 & 11.0 \\
\hline Mixed myr & 489.6 & 9.5 \\
\hline Indeterminable peatlands & 50.5 & 1.0 \\
\hline$\Sigma M y r$ area covered by VMI & $2,739.5$ & 54.0 \\
\hline
\end{tabular}

Wetland science in Sweden started early and a wealth of scientific information is available on mire classification, mire vegetation, and on peat quality and quantity. Unfortunately, most of these data are hardly accessible, barely digitized and several datasets are quite old. Nevertheless, they can be used, if their limitations are considered.

Wetlands cover about 9,300 x $10^{3}$ ha of Sweden (Lonnstad \& Löfroth 1994). Of these wetlands $3,400 \times 10^{3}$ ha has been surveyed by the Swedish Wetland Survey70 ("VMI"; 1981-2005). This survey covered areas of "myr" ${ }^{71}$ Disturbed areas, which do not meet the concept of myr, were only included if they were located within larger wetland complexes. The VMI types were aggregated to seven groups, of which in total 2,739.5 x $10^{3}$ ha have been surveyed by VMI (Table 1,2). Additionally, there is an unknown extent of swamp forests, wet heaths and inundated fens, which partly accumulate peat. About $390.7 \times 10^{3}$ ha of them have been surveyed by VMI.

70 http://www.naturvardsverket.se/978-91-620-6618-5 http://www.naturvardsverket.se/978-91-620-5925-5.pdf

71 "Myrs" in the Swedish Wetland survey are intact peatlands with enough deep peat (often $>0.25 \mathrm{~cm}$ ) to develop a natural bog or fen vegetation (open or forested). This also includes slightly damaged peatlands, where the vegetation still contains a lot of species of natural bog or fen vegetation (Naturvårdsverket 1983). 
Figure 2: Swedish mire regions after Gunnarsson \& Löfroth (2007). 1-Mountain mires; 2-Palsa mires; 3-Northern aapa mires; 4-Central aapa mires; 5-Soligenous aapa mires; 6-Southern aapa mires; 7-Raised bogs; 8-Pine bog-marshes

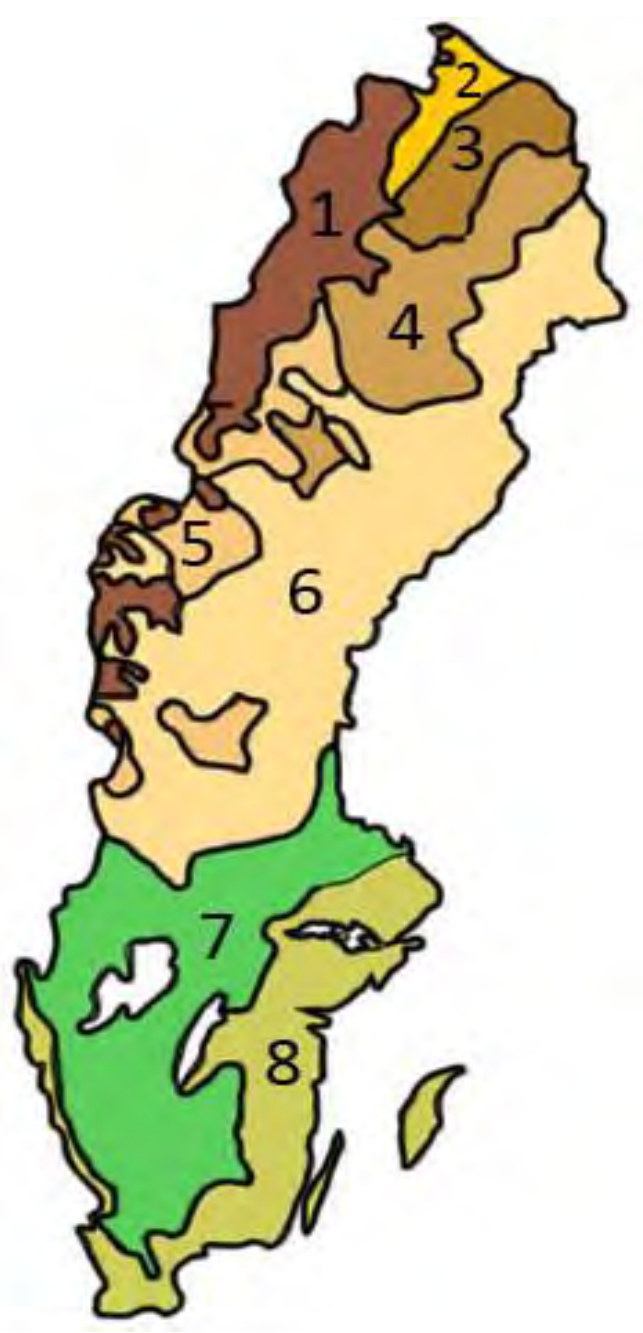

According to the VMI, several myr complexes in southwest Sweden contain large raised bogs (Figure 2). In southeast Sweden, wetlands are smaller and pine bogs more common. Peat thickness is high in the peatlands of the western and central parts of the southern highlands. Peat accumulation has been stimulated there by early deglaciation, abundant rainfall and and a limited number of days with summer drought. In northern and central Sweden large string-flark and string mixed mire complexes are common. 
Excluded from the VMI were a) areas of the alpine zone, b) areas smaller than a regional size limit (mostly $<10$ ha in the nemoral and the boreo-nemoral zone, and mostly $<50$ ha in the boreal zone), and c) totally disturbed areas without vegetation of pristine bogs and fens that no longer can be classified as myr (Gunnarsson \& Löfroth 2007, 2015). For this report we analysed the data on peat forming wetland types and their state from the VMI (Naturvårdsverket 2014).

\subsubsection{Peatland degradation}

Reclaiming wetlands including peatlands for agriculture has been ongoing in Sweden for hundreds of years - especially fens were used for pastures and hay making. Löfroth (2001) estimated that about a fourth ${ }^{72}$ of the original wetland area has been drained and turned to arable land and grasslands, predominantly between 1850 and 1900 (Löfroth 2015). The use of wetlands for agricultural purposes had its maximum between 1920 and 1950. In the middle of the 1940s about $705 \times 10^{3}$ ha of drained peatland were used as arable land or grasslands (Hjertstedt 1946); in 2008 this area had decreased to $170 \times 10^{3}$ ha (Berglund et al. 2009).

Peatlands in Sweden have been drained on a large scale for forestry. Between 1950 and 1990 drainage and afforestation of peatlands significantly increased due to the availability of powerful machinery. In 1986 legislation was implemented that made drainage subject to licensing. In total over $1,500 \times 10^{3}$ ha of wetlands has been drained for forestry, but in approximately $300 \times 10^{3}$ ha this drainage failed to enhance forest production (Hånell 2006).

Small-scale peat extraction has a long history with the peat being used as litter in cow byres and as a domestic fuel (Löfroth 2015). Most farms had an own peat excavation site. In the 19th century larger extraction sites were established. During both World Wars large peat extraction sites were common throughout southern Sweden, as a result of the increased demand for fuel peat. During the energy crises in the 1970s the interests in peat extraction rose again. About $100 \times 10^{6} \mathrm{~m}^{3}$ were excavated between 1980 and 2012 (SCB, 2013b) and the peat extraction area rose from $6.6 \times 10^{3}$ ha in 1990 to $9.8 \times 10^{3}$ ha in 2012 (NIS Sweden

\footnotetext{
72 Includes all wetlands types and probably also the lowering of water tables in lakes, with the aim to enlarge the agricultural land.
} 
2014). Abandoned and active peat extraction sites cover almost $22.0 \mathrm{x}$ $10^{3}$ ha (SCB 2013a).

Nowadays, new drainage of peatlands for agriculture or forestry has almost completely ceased (Naturvårdsverket 2007; Löfroth, 2015). Drainage is forbidden in parts of the country but dispensation can be given. Individual permissions for drainage can only be issued subject to special conditions (Naturvårdsverket 2007).

The "Fourth National report to the Convention on Biological Diversity ${ }^{73}$, $\left(\mathrm{CBD}^{74}\right)$ stated that more than $80 \%$ of the wetland sites are to varying degrees affected by human interventions such as drainage, agriculture and forestry, roads and off-road driving and peat extraction.

For approximately half of the myr area of Sweden, disturbance by human impact has been assessed in the Swedish Wetland Survey (VMI; see Chapter 7.5.2.). The VMI registered the kind and degree of impact for each sub site (each sub site corresponds to a myr type). The most common forms of human impact are "drainage" ( 40\%), "logging" (22\%), and "roads" (17\%; Gunnarsson \& Löfroth 2007, 2014). Naturvårdsverket (2014) summarized the impact per myr type in five classes and aggregated the myr types to myr groups (Table 6, Figure 3). Approximately $30 \%$ of the myr area surveyed appeared to be without impact, whereas the largest area $\left(1,088.5 \times 10^{3}\right.$ ha $\left.=39.7 \%\right)$ had a strong local human impact, including $>50 \%$ of the area of raised bogs and plan-slightly raised bogs and approximately $50 \%$ of the area of topogenous fens (Table 6). Of the concentric, eccentric, plateau, and slightly raised bogs less than $10 \%$ of the total area had remained without impact. Less disturbed are the northern reticulate bogs, strongly sloping fens and palsa mires in the North with each $>75 \%$ of undisturbed area left. The areas "weak local" and "strong local" impact are imprecise since the affected subsites also include areas without impact.

\footnotetext{
${ }^{73}$ https://www.cbd.int/doc/world/se/se-nr-04-en.pdf

74 http://www.cbd.int/
} 


\begin{tabular}{|c|c|c|c|c|c|c|c|c|c|c|c|c|}
\hline \multirow[b]{3}{*}{ Myr types } & \multirow[t]{3}{*}{ Myr groups } & \multirow{3}{*}{$\begin{array}{l}\text { Total } \\
\text { area } \\
10^{3} \mathrm{ha}\end{array}$} & \multicolumn{10}{|c|}{ Degree of impact } \\
\hline & & & \multicolumn{2}{|c|}{$\begin{array}{l}\text { strong } \\
\text { general }\end{array}$} & \multicolumn{2}{|c|}{$\begin{array}{c}\text { weak } \\
\text { general }^{1)}\end{array}$} & \multicolumn{2}{|c|}{ strong local ${ }^{1)}$} & \multicolumn{2}{|c|}{ weak local } & \multicolumn{2}{|l|}{ none } \\
\hline & & & $10^{3}$ ha & $\%$ & $10^{3}$ ha & $\%$ & $10^{3}$ ha & $\%$ & $10^{3}$ ha & $\%$ & $10^{3}$ ha & $\%$ \\
\hline Indeterminable bog & Indeter- & 13.7 & 12.7 & 92.8 & 0.5 & 3.4 & 0.3 & 2.2 & 0.2 & 1.1 & 0.1 & 0.5 \\
\hline Indeterminable fen & "peat- & 1.2 & 0.9 & 73.8 & 0.3 & 22.8 & 0.0 & 0.7 & 0.0 & 0.4 & 0.0 & 2.2 \\
\hline Indeterminable areas & lands" & 35.5 & 32.4 & 91.2 & 1.7 & 4.9 & 0.6 & 1.7 & 0.0 & 0.0 & 0.8 & 2.1 \\
\hline Concentric bog & Raised bog & 19.2 & 0.4 & 2.0 & 0.3 & 1.6 & 12.3 & 64.0 & 4.9 & 25.3 & 1.4 & 7.0 \\
\hline Eccentric bog & & 38.3 & 1.4 & 3.6 & 1.4 & 3.7 & 24.9 & 65.2 & 7.0 & 18.4 & 3.5 & 9.1 \\
\hline Sloping bog & & 43.8 & 1.0 & 2.2 & 2.3 & 5.2 & 25.7 & 58.7 & 7.0 & 16.0 & 7.8 & 17.8 \\
\hline Plateau bog & & 70.9 & 4.5 & 6.4 & 5.0 & 7.0 & 49.2 & 69.5 & 8.2 & 11.6 & 3.9 & 5.6 \\
\hline Slightly raised bog & $\begin{array}{l}\text { Plane- } \\
\text { slightly } \\
\text { raised bog }\end{array}$ & 225.9 & 20.3 & 9.0 & 28.4 & 12.6 & 123.1 & 54.5 & 33.9 & 15.0 & 20.3 & 9.0 \\
\hline Northern bog & Northern & 152.0 & 1.5 & 1.0 & 4.4 & 2.9 & 54.6 & 35.9 & 36.2 & 23.8 & 55.3 & 36.4 \\
\hline Northern reticulate bog & & 1.6 & 0.0 & 0.0 & 0.0 & 0.0 & 0.1 & 6.5 & 0.2 & 12.3 & 1.3 & 81.2 \\
\hline Topogenous fen & $\begin{array}{l}\text { Topoge- } \\
\text { nous fen }\end{array}$ & $1,127.7$ & 47.7 & 4.2 & 51.4 & 4.6 & 512.5 & 45.4 & 240.6 & 21.3 & 275.4 & 24.4 \\
\hline Coastal topogenous fen & & 3.4 & 0.2 & 6.1 & 0.5 & 15.7 & 1.6 & 47.4 & 0.5 & 15.3 & 0.5 & 15.5 \\
\hline String fen & $\begin{array}{l}\text { Soligenous } \\
\text { fen }\end{array}$ & 395.4 & 4.5 & 1.1 & 9.0 & 2.3 & 119.7 & 30.3 & 103.6 & 26.2 & 158.6 & 40.1 \\
\hline Soligenous fen & & 168.1 & 1.0 & 0.6 & 3.5 & 2.1 & 37.2 & 22.1 & 33.4 & 19.8 & 93.0 & 55.4 \\
\hline Strongly sloping fen & & 3.2 & 0.0 & 0.0 & 0.0 & 0.0 & 0.4 & 11.4 & 0.4 & 11.4 & 2.5 & 77.2 \\
\hline Mosaic mixed myr & Mixed myr & 185.9 & 2.3 & 1.2 & 8.3 & 4.5 & 61.7 & 33.2 & 43.9 & 23.6 & 69.5 & 37.4 \\
\hline Palsa myr & & 9.0 & 0.0 & 0.0 & 0.0 & 0.0 & 0.3 & 2.9 & 0.0 & 0.0 & 8.7 & 97.1 \\
\hline String mixed myr & & 294.7 & 3.6 & 1.2 & 2.6 & 0.9 & 65.1 & 22.1 & 64.5 & 21.9 & 158.7 & 53.9 \\
\hline Total & & $2,739.0$ & 88.5 & 3.2 & 117.2 & 4.3 & $1,088.5$ & 39.7 & 584.4 & 21.3 & 860.5 & 31.4 \\
\hline
\end{tabular}

\footnotetext{
1) The calculated areas of the impact classes "weak local" and "strong local" are imprecise since the
} affected sub sites also include areas that have not been affected by the impact. 
Figure 3: The degree of human impact on different myr groups (see Table 2), which together covered $54.1 \%$ of the total myr area (based on data from the Swedish Wetland Inventory)

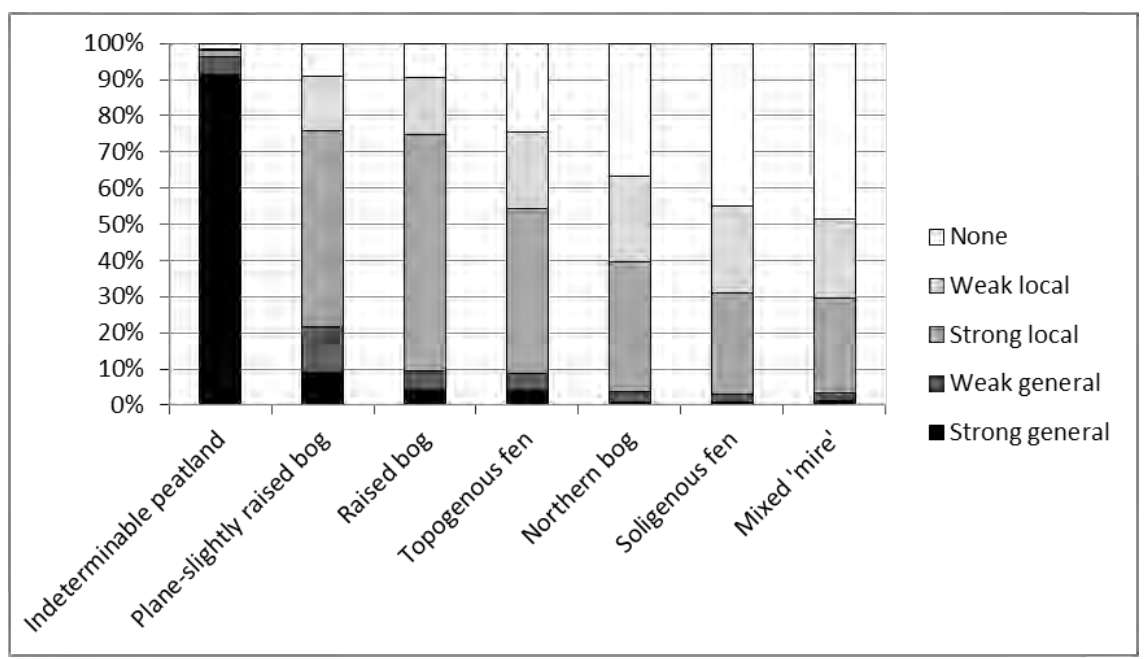

\subsubsection{Current peatland: location, extent, status, land use and greenhouse gas emissions}

\section{Material and Methods}

A "myr", according to the definition of the Swedish Wetland survey, is "an intact peatland with enough deep peat (often $>0.25 \mathrm{~cm}$ ) to develop a natural bog or fen vegetation (open or forested). This also includes slightly damaged peatlands, where the vegetation still contains a lot of species of natural bog or fen vegetation."

To assess the peatland area of Sweden we used

- the GIS data from the Geological Survey of Sweden ("Sveriges geologiska undersökning" - SGU75) on peat distribution derived from the local Quaternary deposits database for Sweden (CSGU). We used several polygon vector layers of different scales: a) "torv25_100k"; b) "torv_250k"; c) "kärrtorv"; and d) "torv_tidvis_under_vatten (Figure 1). The dataset "torv_750k" was not used since it was considered unsuitable for the integration with the larger scale peatland datasets. 
We unified these different scale vector polygon datasets on "torv" to one integrated peatland vector dataset. However, this new dataset does not cover entire Sweden (Figure 1). In order to fill the gaps in peat data coverage, we extracted the following cells from the land use raster dataset KartdataKNAS (see below): "forest on wetland", "wetland", "inland and salt marshes", "grazed or mowed wetland", and "peat extraction site". The peat vector data and the extracted raster cells from the land use dataset (as substitute for the data gaps in the peat datasets) were unified to one polygon vector layer of "peatlands"76 covering entire Sweden.

To assess land use on "peatlands" in Sweden we used

- the KartdataKNAS ver6 GIS data from Naturvårdsverket, which was produced by "Metria $\mathrm{AB}$ " - a consultancy for geographical information and geographical information technology. ${ }^{77}$ This raster data set with $10 \times 10 \mathrm{~m}$ grid size covers entire Sweden.

The KartdataKNAS land use classes are based upon numerous different data sets, 78 e.g. topographic maps, land use data from the "SMD" (Swedish Corine Land cover from Metria 2000) and the "Inventory of meadows and pastures" from the Swedish Board of Agriculture (2005). The SMD has among others contributed the classes "wetland" (mostly peatlands) and "peat extraction sites". The "Inventory of meadows and pastures" contributed the class "grazed wetlands". The Alpine climate/vegetation zone only has one wetland class - "wetlands", that was included in KartdataKNAS ver6.

The KartdataKNAS data set has a number of deficiencies, as some land use classes are based on basic topographic maps that have not been updated for a long time in several areas. Wetlands can have been drained and turned to forest and arable land, whereas meadows and pastures can have been turned to forest. Many small wetlands and wet forest on peat have been excluded during the generalization of the KartdataKNAS data set. The quality outside protected areas is less than within and this should be kept in mind when using this data.

76 We write the term "peatland" further with inverted commas to indicate that peat occurrence is not confirmed for all "forest on wetland', "wetland', "inland and salt marshes," "grazed or mowed wetland," and "peat extraction site," which were integrated in the new dataset.

77 http://www.metria.se. The dataset was delivered by Camilla Jönsson; Metria GIS-Support WEBB; Metria Geoanalys (2009).

${ }^{78}$ For more information see: http://www.snsb.se/Global/Fj\%C3\%A4rranalysanv\%C3\%A4ndare/Fj\%C3\%

A4rranalysdagarna\%20presentationer/2.1A_Camilla_j\%C3\%B6nsson_kontinuelig_naturtypskartering.pdf 
Because if lacking alternative data, we have assigned a drainage status to the land use types on peat derived from the GIS analysis of this project (see Table 3).

\begin{tabular}{|c|c|c|c|c|c|}
\hline $\begin{array}{l}\text { Grid } \\
\text { code }\end{array}$ & $\begin{array}{l}\text { Land use category } \\
\text { (KartdataKNAS) }\end{array}$ & $\begin{array}{l}\text { Land use type } \\
\text { (GIS study) }\end{array}$ & $\begin{array}{l}\text { Grid } \\
\text { code }\end{array}$ & $\begin{array}{l}\text { Land use category } \\
\text { (KartdataKNAS) }\end{array}$ & $\begin{array}{l}\text { Land use type(GIS } \\
\text { study) }\end{array}$ \\
\hline 1 & Forest $^{1)}$ & $\begin{array}{l}\text { Drained } \\
\text { forested }^{2)}\end{array}$ & 14 & $\begin{array}{l}\text { Grazed mowed } \\
\text { wetland }\end{array}$ & Drained agriculture \\
\hline 201 & Forest $^{1)}$ & $\begin{array}{l}\text { Drained } \\
\text { forested }^{2)}\end{array}$ & 15 & Peat extraction & Drained peat extraction \\
\hline 202 & Forest $^{1)}$ & $\begin{array}{l}\text { Drained } \\
\text { forested }^{2)}\end{array}$ & 16 & Agriculture & Drained agriculture \\
\hline 203 & Forest $^{1)}$ & $\begin{array}{l}\text { Drained } \\
\text { forested }^{2)}\end{array}$ & 17 & Meadow & \\
\hline 204 & Forest $^{1)}$ & $\begin{array}{l}\text { Drained } \\
\text { forested }^{2)}\end{array}$ & 18 & Pasture & Drained agriculture \\
\hline 205 & Forest $^{1)}$ & $\begin{array}{l}\text { Drained } \\
\text { forested }^{2)}\end{array}$ & 19 & Bare land & \\
\hline 2 & Forest $^{11}$ on wetland & $\begin{array}{l}\text { Drained } \\
\text { forested }^{2)}\end{array}$ & 20 & Other open land & Drained other land \\
\hline 3 & Montane pine forest & $\begin{array}{l}\text { Undrained } \\
\text { forested }\end{array}$ & 21 & Infrastructure & \\
\hline 4 & Montane birch forest & $\begin{array}{l}\text { Undrained } \\
\text { forested }\end{array}$ & 22 & Infrastructure & Drained infrastructure \\
\hline 5 & $\begin{array}{l}\text { Other open land } \\
\text { mountains }\end{array}$ & $\begin{array}{l}\text { Undrained } \\
\text { open }^{3)}\end{array}$ & 23 & Inland water & Undrained inland water \\
\hline 12 & Wetland & $\begin{array}{l}\text { Undrained } \\
\text { open }^{3)}\end{array}$ & 24 & Sea & Not applicable \\
\hline 13 & Inland and salt marshes & $\begin{array}{l}\text { Undrained } \\
\text { open }^{3)}\end{array}$ & 99 & Undefined & Undefined \\
\hline
\end{tabular}

\footnotetext{
${ }^{1)}$ Forest with a cover of the tree canopy more than $30 \%$ (pers. comm. Jenny Lonnstad).

${ }^{2)}$ Many sites are fully or partly affected by drainage, especially in the South. The large wetland complexes of the North are less affected (pers. comm. Jenny Lonnstad) which may lead to some overestimation of the drained forest area (Table 4).

${ }^{3)}$ Probably also includes some drained sites (pers. comm. Jenny Lonnstad).
} 
Figure 4: Coverage of the peat vector data sets for Sweden (from SGU, see above). We integrated all peat vector data (except "torv_750k") for this study. Red circles: areas without coverage of peat data from $S G U$

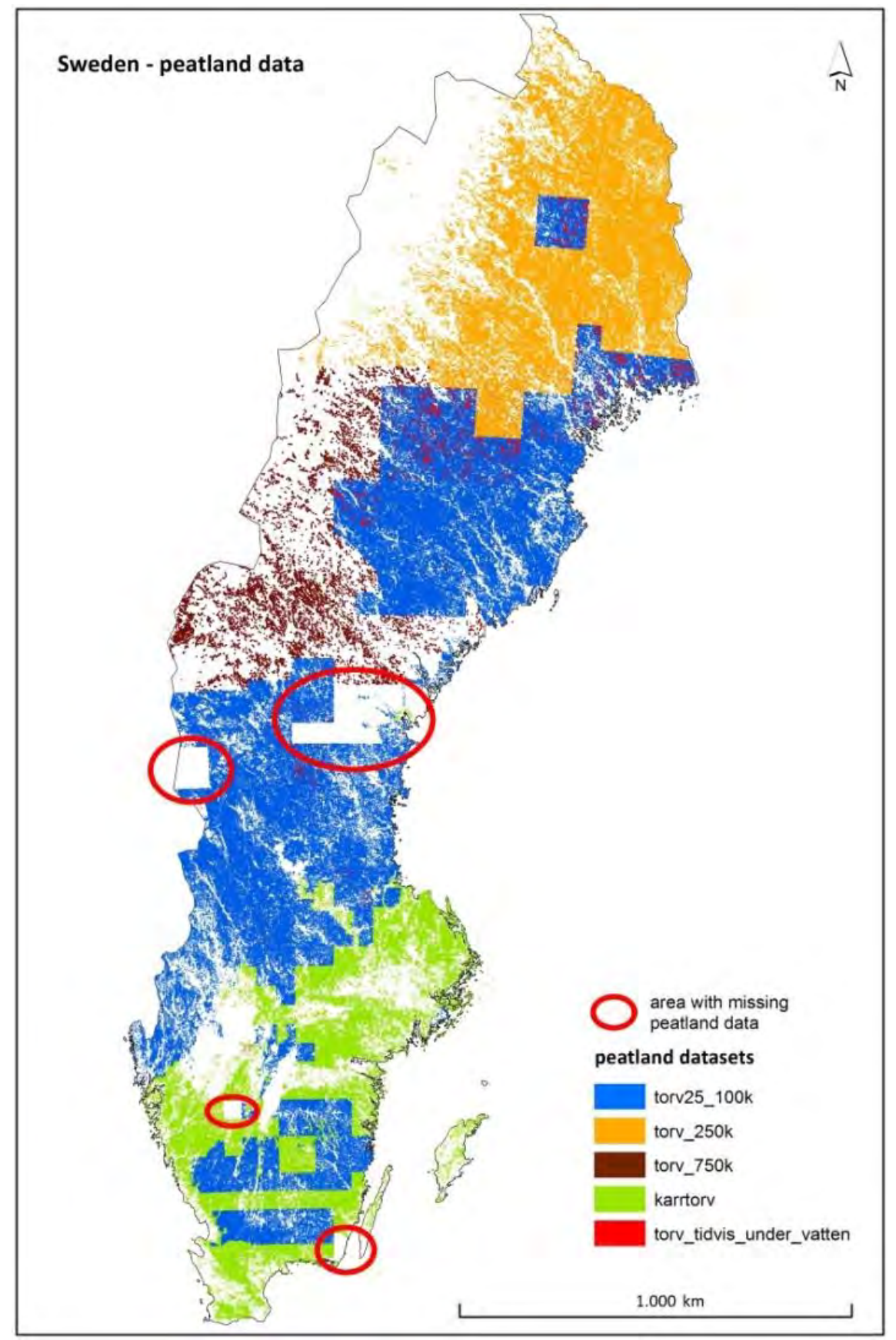


The integrated "peatland" dataset (see above) was blended with the reclassified land use dataset (Table 3). As result, we obtained a $10 \times 10$ $m$ raster on "peatland" distribution and associated land use in Sweden (Figure 5). Because of the different scales of the separate SGU "torv"_datasets (Figure 4), the shortcomings of the integrated "peatland" dataset (see above) and the assumed drainage status of the land use types on "peatland" (Table 3), this resulting "peatland" map (Figure 5) has several uncertainties.

For assessing the area of drained organic soils, we furthermore considered the area data from

- the recent National Inventory Submission of Sweden to the United Nations Framework Convention on Climate Change (UNFCCC; "NIS79 Sweden 2014"). ${ }^{80}$

The NIS Sweden (2014) provides information on Forest Land and Grassland on drained organic soil based on the National Forest Inventory ("NFI"; Swedish = "RIS" - "Riksinventeringen av skog"). The NFI is based on around 30,000 (originally 40,000) permanent sample plots representing the entire country. These plots are being re-inventoried at intervals of 5-10 years. The NIS has assessed the area of Cropland on organic soil based on digitised maps of Quaternary deposits, $40 \mathrm{~K}$ radiation and agricultural databases (IACS, Berglund et al. 2009, NIS Sweden 2014).

We did not calculate $\mathrm{CO}_{2}$ emissions for the resulting "peatland" areas from our GIS overlay analysis, because of the data uncertainties (see above). Instead we calculated the emissions for Grassland and Peat extraction using the area data given for drained organic soils in NIS Sweden (2014) and using the Tier 1 default emission factors for $\mathrm{CO}_{2}$ from IPCC (2014) for the Boreal climate. Emissions from Forest Land on drained organic soils were calculated using the Tier 1 default emission factors from IPCC (2014) for Boreal and Temperate climates (see Table 5). For Cropland we applied the emission factor suggested by Lindgren \& Lundblad (2014), despite the facts that IPCC (2014) did not find a significant difference in emissions between Boreal and Temperate Cropland,

\footnotetext{
79 The National Inventory Submission ('NIS') consists of the National Inventory Report ('NIR') and the Common Reporting Format ('CRF'). Since both the NIR and the CRF were used, we further refer to the complete National Inventory Submission of Sweden (NIS Sweden 2014).

80 https://unfccc.int/national_reports/annex_i_ghg_inventories/national_inventories_submissions/ items/8108.php
} 
and that the main part of the organic soils used as Cropland can be expected in Temperate, ${ }^{81}$ southern Sweden.

Carbon loss from DOC (Dissolved Organic Carbon) is not included in this study.

Peat carbon stock estimates were derived from Christensen \& Friborg (2004).

\section{Results}

According to the GIS overlay analysis of the raster data from SGU and Naturvårdsverket (see Material and Methods) the "peatland" area of Sweden is $6,915.5 \times 10^{3}$ (Table 4), or approximately $17 \%$ of the total land area. ${ }^{82}$ Furthermore, the analysis gives an area of $2,444.6 \times 10^{3}$ ha of "peatlands" drained for forestry. Since "peatland" complexes in the North are less affected by forestry drainage, whereas all forests have been classified as "drained" in the reclassified land use dataset (see Table 3, Material and Methods), this figure is an overestimation. Drained "peatlands" used for agriculture cover an area of $94.0 \times 10^{3}$ ha, and peat extraction sites $17.4 \times 10^{3}$ ha (Table 4).

Table 4: Area, land use types and assumed drainage status of "peatlands" in Sweden according to our GIS overlay analysis (Material and Methods). Land use types do not correspond to UNFCCC/IPCC land use categories

\begin{tabular}{|c|c|c|c|c|c|}
\hline \multirow[t]{2}{*}{ “Peatlands" } & \multirow{2}{*}{$\begin{array}{l}\text { Total } \\
10^{3} \text { ha }\end{array}$} & \multicolumn{2}{|c|}{ Undrained } & \multicolumn{2}{|c|}{ Drained } \\
\hline & & $10^{3}$ ha & $\%$ & $10^{3}$ ha & $\%$ \\
\hline Undrained open & & $4,169.3$ & 60.3 & & \\
\hline Undrained forested & & 65.1 & 0.9 & & \\
\hline Undrained inland water & & 38.6 & 0.6 & & \\
\hline Drained forested & & & & $2,444.6$ & 35.3 \\
\hline Drained agriculture & & & & 94.0 & 1.4 \\
\hline Drained peat extraction & & & & 17.4 & 0.3 \\
\hline Drained infrastructure & & & & 4.8 & 0.1 \\
\hline Drained other land & & & & 81.9 & 1.2 \\
\hline Undefined & & & & 0.0 & 0.0 \\
\hline$\sum$ Subtotals & & $4,273.0$ & 61.8 & $2,642.5$ & 38.2 \\
\hline$\sum$ Total & $6,915.5$ & & & & \\
\hline
\end{tabular}

81 http://eusoils.jrc.ec.europa.eu/projects/RenewableEnergy/

82 The total area of Sweden is $40,730 \times 10^{3}$ ha (SCB 2013a). 
Figure 5: Location and extent of "peatlands" in Sweden and the applied land use types (our GIS overlay analysis). Land use types do not correspond to UNFCCC/IPCC land use categories. This map has various uncertainties (see Material and Methods)

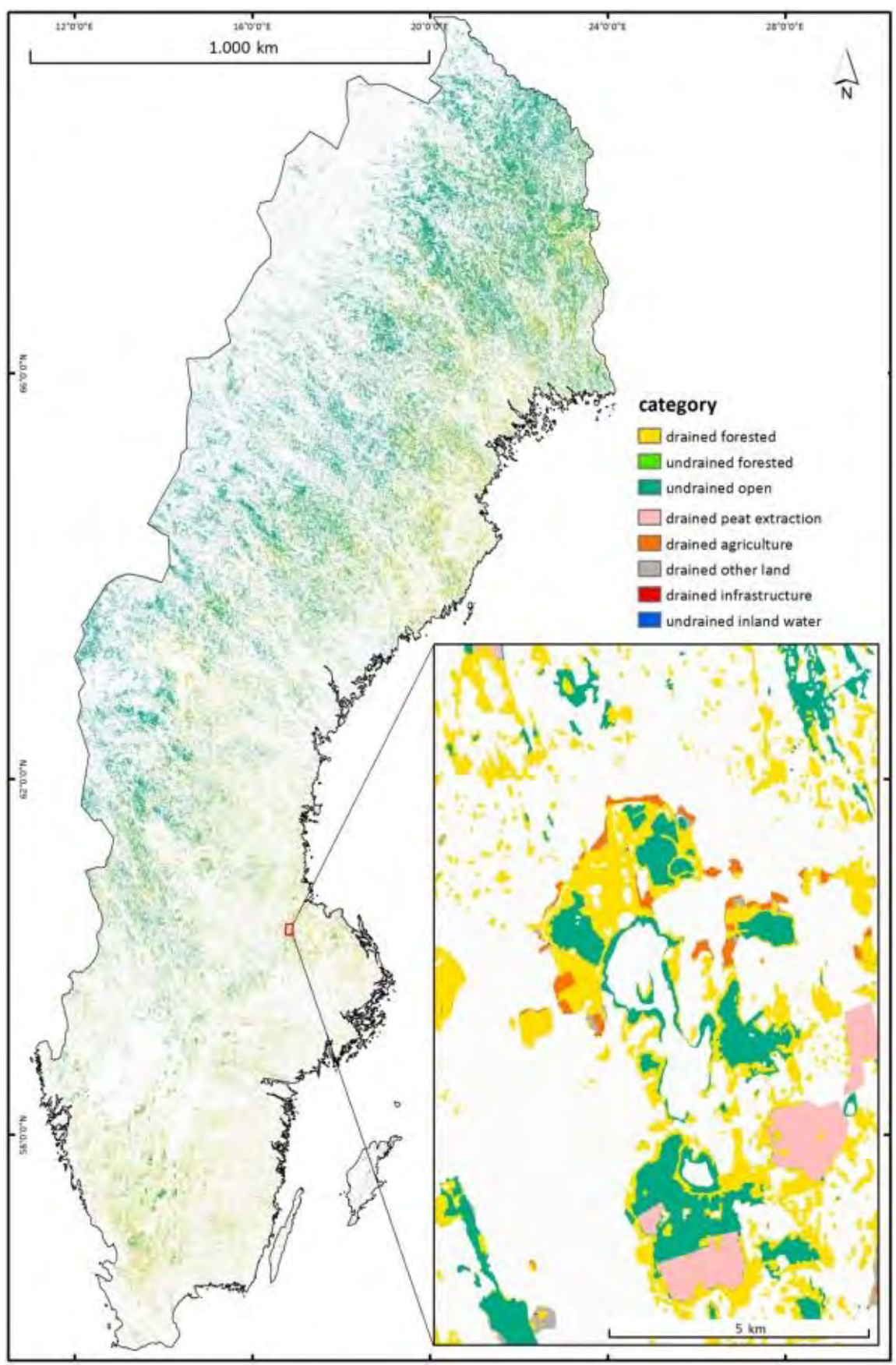


The distribution of "peatlands" in Sweden is distinctly uneven. The majority of "peatlands" is located in central and northern Sweden, where large areas are still unaffected by drainage (Figure 5). Many "peatlands" in southern Sweden are drained and intensively used. Large mire sites with small impact still do exist (Figure 5), but often these complexes have ditches at their margins (pers. comm. Jenny Lonnstad).

The National Inventory Submission of Sweden (NIS Sweden 2014) reported 1,330.0 $\times 10^{3}$ ha of Forest Land on drained organic soil (including 1,200 x $10^{3}$ ha "well drained" and $130.0 \times 10^{3}$ ha "poorly drained" organic soils), $144.4 \times 10^{3}$ ha Cropland on drained organic soil, $61.6 \times 10^{3}$ ha of Grassland on drained organic soil, and $9.8 \times 10^{3}$ ha of organic soil drained for Peat extraction (Table 6; NIS Sweden 2014). Drainage and use of these areas lead, according to the NIS Sweden, to an annual $\mathrm{CO}_{2}$ emission of $6.2 \mathrm{Mt}$ (Table 5).

According to Christensen and Friborg $(2004,83$ based on Lappalainen 1996), the overall peat carbon stock in Sweden is $4,550 \mathrm{Mt}$.

\section{Discussion}

Lindgren \& Lundblad (2014) applied new emission factors (using IPCC 2014) and elaborated new area data of drained organic soils as suggestions for Sweden's 2015 National Inventory Report. They differentiated the total organic soil area in Forest Land and Grassland and used the emission factors for "Boreal" and "Temperate" climates (which reflects the climatic situation of Sweden, see Chapter 7.5.1.) and for "rich" and "poor" nutrient status. The area estimates of Lindgren \& Lundblad (2014) differ considerably from those in the NIS Sweden (2014): 877.0 instead of $1330.0 \times 10^{3}$ ha of Forest Land (a difference of $453 \times 10^{3}$ ha); and 23.0 instead of $61.6 \times 10^{3}$ ha for Grassland (a difference of $38.6 \times 10^{3}$ ha; see Table 6). As a result, the total area of organic soils considered as affected by drainage of Lindgren \& Lundblad (2014) is about $30 \%$ less than the total area reported in NIS Sweden (2014; Table 6).

Lindgren \& Lundblad (2014) based (similar to as NIS Sweden 2014) their estimate of the extent of Forest Land on drained organic soil on the National Forest Inventory of Sweden. Criteria for area calculation in Lindgren \& Lundblad (2014) followed and included a) the international Forest Land definition, b) the Histosol definition, c) the presence of ditches, ${ }^{84}$ and

\footnotetext{
$83 \mathrm{ftp} / / / \mathrm{ftp}$. bgc-jena.mpg.de/pub/outgoing/athuille/Umweltgeochemie/Peatreport_final.pdf 84 Drained areas were identified in Forest Land (and probably also in Grassland) based on the occurrence of a ditch in $25 \mathrm{~m}$ distance from the sample point (NFI). This probably underestimates the actual drained area.
} 
d) soil moisture (excluding "wet" and "moist" soils). Apparently, Lindgren \& Lundblad (2014) assume that "wet" and "moist" organic soils (as defined by NFI) are "poorly drained", do not apply to the IPCC (2014) default emission factors for drained organic soils and subsequently exclude these areas from their estimate. In contrast, the Swedish NIS (2014) seems to report emissions from a part of these soils. Moreover, the area of Forest Land on drained organic soils has been reported as unchanged from 1990 until the 2014 reporting $\left(1,300 \times 10^{3}\right.$ ha, including $1,200 \times 10^{3}$ ha "well drained" and $130.0 \times 10^{3}$ ha "poorly drained" soils; NIS Sweden 2014, Annex Table A3: 2.7). We advise that for the next reporting the assumption that "moist" and "wet" soils have no net greenhouse gas emissions is substantiated and that the changes in criteria used are comprehensible disclosed. Nevertheless, the area of "poorly drained" soils should anyhow be included explicitly in the upcoming National Inventory Report, even if net soil emissions were zero, because it constitutes managed Forest Land. The land has been included under KP Article 3.4 "Forest Management" and should be tracked in all subsequent KP accounting.

The area of Grassland on drained organic soil presented by Lindgren \& Lundblad (2014) is only $37 \%$ of the area reported in NIS Sweden (2014): 23.0 instead of $61.6 \times 10^{3}$ ha (Table 6). This considerable change in the reported area should be justified in the upcoming National Inventory Report. For emission calculation in Table 5 we have used the area data from NIS Sweden (2014) (see also Table 6), but we applied the emissions factors for Forest Land stratified for climate and nutrient status ("boreal, rich", "boreal, poor", "temperate, rich" and "temperate, poor") of Lindgren \& Lundblad (2014). As the distribution of the "missing" $453.0 \times 10^{3}$ ha of Forest Land on organic soils is not known to us, we use applied, as rough approximation, the fractioning (\%) of these subtypes for the $877.0 \times 10^{3}$ ha of Forest Land on drained organic soil of Lindgren \& Lundblad (2014) to the total $1,200.0 \times 10^{3}$ ha of Forest Land on "well drained" organic soils of NIS Sweden $(2014$, see Table 5, 6).

For comparison: the NIR Iceland (2014) assumes the drainage effect to extend to a distance of $200 \mathrm{~m}$ from each side of a ditch. 
Table 5: Drained organic soil areas, land use types and associated $\mathrm{CO}_{2}$ emissions. Area estimates as reported in the NIS Sweden (2014) to the UNFCCC (except area stratification of Forest Land)

\begin{tabular}{|c|c|c|c|c|c|}
\hline Sweden & $\begin{array}{r}\text { Area of } \\
\text { organic soil } \\
\left(10^{3} \text { ha }\right)\end{array}$ & Area source & $\begin{array}{r}\text { Net carbon } \\
\text { stock change } \\
\text { per area } \\
\left(\mathrm{t} \mathrm{CO}_{2} / \mathrm{ha} / \mathrm{yr}\right)\end{array}$ & $\begin{array}{l}\text { Emission factor } \\
\text { source }\end{array}$ & $\begin{array}{r}\text { Emissions } \\
(\mathrm{Mt} \\
\left.\mathrm{CO}_{2} / \mathrm{yr}\right)\end{array}$ \\
\hline Land Use Category & & \multirow{8}{*}{$\begin{array}{l}\text { NIS Sweden } \\
\text { (2014) \& } \\
\text { Lindgren \& } \\
\text { Lundblad } \\
\text { (2014) }\end{array}$} & & \multirow[t]{9}{*}{ IPCC (2014) } & \\
\hline $\begin{array}{l}\text { Forest Land remaining Forest Land } \\
\text { well drained, boreal, rich }\end{array}$ & $428.4^{1)}$ & & 3.41 & & 1.46 \\
\hline well drained, boreal, poor & $331.2^{11}$ & & 0.92 & & 0.30 \\
\hline well drained, temperate, rich & $369.5^{1)}$ & & 9.53 & & 3.52 \\
\hline well drained, temperate, poor & $70.9^{1)}$ & & 9.53 & & 0.68 \\
\hline$\sum$ well drained & $1,200.0$ & & & & 5.96 \\
\hline poorly drained & $130.0^{21}$ & & ? & & ? \\
\hline$\sum$ Total Forest Land & $1,330.0$ & & & & 6.87 \\
\hline Cropland remaining Cropland & 141.1 & NIS Sweden & 22.37 & & 3.16 \\
\hline Forest Land converted to Cropland & 0.2 & (2014) & 22.37 & \multirow{6}{*}{$\begin{array}{l}\text { Lindgren \& Lundblad } \\
\text { (2014) }\end{array}$} & 0.01 \\
\hline Grassland converted to Cropland & 2.1 & & 22.37 & & 0.05 \\
\hline Wetland converted to Cropland & 0.1 & & 22.37 & & 0.00 \\
\hline Settlement converted to Cropland & 0.9 & & 22.37 & & 0.02 \\
\hline$\Sigma$ Cropland & 144.4 & & & & 3.23 \\
\hline Grassland remaining Grassland & 49.8 & NIS Sweden & 20.90 & & 1.04 \\
\hline Forest Land converted to Grassland & 3.8 & (2014) & 20.90 & IPCC (2014) & 0.08 \\
\hline Cropland converted to Grassland & 6.8 & & 20.90 & Grassland, drained & 0.14 \\
\hline Wetland converted to Grassland & 0.4 & & 20.90 & \multirow[t]{4}{*}{ Boreal } & 0.01 \\
\hline Settlement converted to Grassland & 0.5 & & 20.90 & & 0.01 \\
\hline Other Land converted to Grassland & 0.3 & & 20.90 & & 0.01 \\
\hline$\sum$ Grassland & 61.6 & & & & 1.29 \\
\hline Wetlands remaining Wetlands & & & & \multirow[t]{5}{*}{ IPCC (2014) } & \\
\hline Peat Extraction & 9.8 & NIS Sweden & 10.27 & & 0.10 \\
\hline Wetlands & $6,956.5$ & (2014) & \pm 0 & & \pm 0 \\
\hline$\Sigma$ Wetlands & 9.8 & & & & 0.10 \\
\hline$\sum$ TOTAL Drained & $1,545.8$ & & & & 10.58 \\
\hline
\end{tabular}

1) These four area estimates together correspond to the total area of $1,200.0 \times 10^{3}$ ha of Forest Land on "well drained" organic soil as reported in NIS Sweden (2014, Annex p. 82). The stratification of this total area according to climate zone and nutrient status follows the apportionment of the stratified organic soil areas for Forest Land from Lindgren \& Lundblad (2014), who only consider an area of $877.0 \times 10^{3}$ ha of Forest Land on drained organic soils, while "excluding wet and moist soils" (as defined by the Swedish NFI). This considerable change in the Forest Land area should be justified.

${ }^{2)}$ Area as reported in NIS Sweden (2014) for Forest Land on "poorly drained", organic soil.

Lindgren \& Lundblad (2014) used the IPCC (2014) default emission factors for $\mathrm{CO}_{2}$ for Forest Land, and Peat extraction. For Grassland on drained organic soil, however, they suggest the application of the emission factors for Forest Land, because the Grassland would predominantly be semi-natural pasture, whereas high intensity Grassland and shallow-drained sites do not occur. We therefore apply the lower IPCC emission factor for "drained, Boreal Grassland" (5.70 t C/ha/yr $=20.90 \mathrm{t}$ $\mathrm{CO}_{2} / \mathrm{ha} / \mathrm{yr}$ ) to estimate emissions from low intensity Temperate and Boreal Grassland. This Boreal emission factor does not differentiate between deep- and shallow-drained sites.

Recalculated, annual $\mathrm{CO}_{2}$ emissions from drained organic soils for Forest Land, Cropland, Grassland, and Peat extraction in Sweden sum up 
to 10.6 Mt (Table 5). This huge increase compared to NIS Sweden (2014) is mainly attributable to the higher emission factors for Cropland and Grassland and the separate, climate based consideration of Temperate and Boreal Forest Land with appropriate emission factors (cf. IPCC 2014; Lindgren \& Lundblad 2014).

Table 6: Areas of drained "peatlands" and organic soils in Sweden. Land use types only correspond to UNFCCC/IPCC land use categories for NIS Sweden (2014) and Lindgren \& Lundblad (2014)

\begin{tabular}{|c|c|c|c|}
\hline \multirow[b]{2}{*}{ Land use type } & \multicolumn{3}{|c|}{ Area per land use type $\left(10^{3} \mathrm{ha}\right)$} \\
\hline & $\begin{array}{r}\text { NIS Swe- } \\
\text { den (2014) }\end{array}$ & $\begin{array}{r}\text { Lindgren \& } \\
\text { Lundblad (2014) }\end{array}$ & $\begin{array}{r}\text { Our GIS } \\
\text { overlay } \\
\text { analysis }^{85}\end{array}$ \\
\hline undrained "peatland", open & & & $4,169.3$ \\
\hline undrained "peatland", forestry & & & 65.1 \\
\hline undrained "peatland", "inland water"1) & & & 38.6 \\
\hline$\sum$ subtotal undrained "peatland" & & & $4,273.0$ \\
\hline drained "peatland", agriculture & & & 94.0 \\
\hline drained "peatland", forestry" & & & $2,444.6$ \\
\hline drained "peatland", peat extraction & & & 17.4 \\
\hline$\sum$ subtotal drained "peatland" & & & $2,642.5$ \\
\hline$\sum$ total "peatland" & & & $6,915.5$ \\
\hline well drained organic soil, Forest Land & $1,200.0$ & & \\
\hline poorly drained organic soil, Forest Land & 130.0 & & \\
\hline$\sum$ drained organic soil, Forest Land & $1,330.0^{2)}$ & 877.0 & \\
\hline drained organic soil, Boreal, rich & & 313.0 & \\
\hline drained organic soil,Boreal, poor & & 242.0 & \\
\hline drained organic soil,Temperate, rich & & 270.0 & \\
\hline drained organic soil, Temperate, poor & & 52.0 & \\
\hline drained organic soil, Cropland & 144.4 & & \\
\hline drained organic soil, Grassland & 61.6 & 23.0 & \\
\hline boreal, rich & & 1.0 & \\
\hline temperate, rich & & 22.0 & \\
\hline drained organic soil, Peat extraction & 9.8 & & \\
\hline$\sum$ total drained organic soil & $1,545.8$ & $1,054.0$ & \\
\hline undrained organic soil in Wetlands & $6,956.5$ & & \\
\hline$\sum$ total organic soil & $8,502.3$ & & \\
\hline
\end{tabular}

1) This classification derives from the KartdataKNAS land use data set (see Material and Methods)

2) The figure is probably an overestimate, as all forested "peatlands" are assumed to be drained (see Material and Methods).

The recently released report "Emissions of Greenhouse Gases from Peatland" from the "Swedish Board of Agriculture" 86 arrives at even higher $\mathrm{CO}_{2}$ emissions (11.4 Mt annually) from drained peatlands under agricultural and forestry use in Sweden.

85 Please note the deficiencies of the GIS data used for this analysis (see Material and Methods).

${ }^{86} \mathrm{http}$ ///www.paneuropeannetworks.com/environment/report-restored-peatlands-reduce-emissions/ 


\subsubsection{Peatland hotspots for conservation, restoration and emission reduction}

An evaluation of the most promising restoration sites in Sweden (hot spots) is still needed. This evaluation could consider both greenhouse gas emission reduction and biodiversity, or focus on greenhouse gas emission reduction solely.

The western and central parts of the southern highlands of Sweden comprise many large bogs with deep peat layers, which also have a high nature conservation value. These bogs are often impacted by drainage at their margins. Restoration of these areas would secure large amounts of stored carbon. According to several models for climate change, the western and central parts of the southern highlands of Sweden will probably become wetter and warmer, which may enhance the growth conditions for Sphagnum and may thus increase the carbon sequestration rates. Other parts of the raised bog region (see Figure 4) may also offer promising sites for restoration for biodiversity and climate.

There are some peatlands in Sweden already targeted for restoration. The bog complexes Anderstorps Store Mosse, Store Mosse and Komosse has been targeted for biodiversity reasons only, but their restoration provides other ecosystem services as well (e.g. greenhouse gas emission reduction). Other large peatland areas which may be considered for restoration on account of their high conservation values are the bog complexes Konungsömosse, Vakö Myr and Rösjö Mosse, which all are situated in southern or south-western Sweden.

Some drained peatlands with current low nature conservation values could also be considered for restoration, especially those which emit huge amounts of greenhouse gases as drained arable land, long-time fallows or unsuccessfully drained forests. Criteria for their selection would be a) a thick peat layer (high mitigation potential for greenhouse gas emissions), and b) additional benefits for the environment. An additional goal could be the enlargement of the near-natural wetland area in these regions of Sweden with severe human impact on wetlands and/or with a small total wetland area.

Solely considering the climate impact of drained peatlands (greenhouse gas emissions), those with thick peat layers in agricultural use, fertilized and/or abandoned, are target sites for restoration. Additionally, forested peatlands with failed drainage are of interest for restoration projects. They cover approximately $300 \times 10^{3}$ ha in Sweden.

If additionally a high nature conservation value would be considered, restoration of damaged mires (especially bogs) consisting of protected areas (e.g. by national legislation or Natura 2000 sites) and unprotected 
sites with high conservation value, would be of special interest (e.g. sites of the "Swedish Mire Protection Plan"87).

\subsubsection{Acknowledgements}

We thank Jenny Lonnstad for her valuable contribution to the country chapter of Sweden, and Jan-Åke Nilsson from Sveriges geologiska undersökning (SGU) as well as Camilla Jönsson from Metria for GIS data preparation and their fast delivery.

\subsubsection{References}

Berglund Ö., Berglund K. \& Sohlenius G. (2009). Organogen jordbruksmark i Sverige 1990-2008. Swedish University of Agricultural Sciences, Department of Soil Sciences, Division of Hydrotechnics Report 12, Uppsala 2009.

Fredén C. (red.), (1994). Berg och Jord. Sveriges Nationalatlas. Bokförlaget Bra Böcker, Höganäs, (Distribueras även genom SGU, Uppsala), 208 p.

Gunnarsson U. \& Löfroth M. (2007). Våtmarksinventeringen - resultat från 25 års inventeringar. Nationell slutrapport för våtmarksinventeringen (VMI) i Sverige. Naturvårdsverket Rapport 5925.

Gunnarsson U. \& Löfroth M. (2014). The Swedish Wetland Survey - compiled excerpts from the national final report. Naturvårdsverket Rapport 6618.

Hånell B. (2006). Effektiv skogsskötsel på torvmarker. In: Strömgren M. (ed.), Växthuseffekt och skogsproduktion: Hur ska vi hantera våra dikade skogsmarker? Rapporter i skogsekologi och skoglig marklära Rapport 90, Institutionen för skoglig marklära, Uppsala, Sveriges lantbruksuniversitet.

Lantmäteriet (2009). Ny metod för kontinuerlig naturtypskartering av skyddade områden (KNAS). Metria Geoanalys.

Lantmäteriet et. al. (2013). Geodetisk och fotogrammetrisk mätnings- och beräkningsteknik.

Lindgren A. \& Lundblad M. (2014). Towards new reporting of drained organic soils under the UNFCCC - assessment of emission factors and areas in Sweden. Swedish University of Agricultural Sciences, Report 14.

Loberg B. (1980). Geologi - material, processer och Sverige berggrund. 3:e utvidgade upplagan. Norstedts.

Lonnstad J. \& Löfroth M. (1994). Myrskyddsplan för Sverige. Naturvårdsverket.

Löfroth M. (2001). Våtmarkernas situation och långsiktiga förändringar. In: Agerlind G. (ed.), Landskapet: restprodukt eller medvetet skapat? Kungl. skogs och lantbruksakademins tidsskrift 140: 47-60.

\footnotetext{
87 http://ec.europa.eu/environment/life/project/Projects/index.cfm?fuseaction=search. dspPage\&n _proj_id $=45$
} 
Löfroth M. (2015). Sweden. In: Joosten H., Tanneberger F., Moen, A. (eds.), Mires and peatlands of Europe - Status, distribution, and nature conservation, Schweizerbart Science Publishers, Stuttgart, Germany.

Metria (2000). Svenska Marktäckedata. (Swedish CORINE Land Cover 2000); available at: http://gpt.vic-metria.nu/data/land/SMD_ produktbeskrivning_20140627.pdf

Metria (2009). Ny metod för kontinuerlig naturtypskartering av skyddade områden (KNAS).

Naturvårdsverket (1983). Inventering av Sverige våtmarker - metodik (snvpm 1680). Solna: Statens naturvårdsverk, $77 \mathrm{p}$.

Naturvårdsverket (2007). Myllrande våtmarker - Underlagsrapport till fördjupad utvärdering av miljömålsarbetet. Naturvårdsverket rapport 5771.

Naturvårdsverket (2014). Våtmarksinventeringen uttag av arealdata om ingreppsnivåer per delobjekttyp (Ärende NV-03816-14)

NIS Sweden (2014).88 National Inventory Report Sweden. Greenhouse Gas Emission Inventories 1990-2012, submitted under the United Nations Framework Convention on Climate Change and the Kyoto Protocol. Swedish Environmental Protection Agency, 512 p. + Annexes.

Nordiska ministerrådet (1977). Naturgeografisk regionindelning av Norden. NU B 1977:34.

SCB(Statistiska centralbyrån) (2013a). Markanvändningen i Sverige. (Sjätte utgåvan). SCB (Statistiska centralbyrån) (2013b). Torv 2012 Produktion, användning, miljöeffekter. Statistiska meddelanden MI 25 SM 1303.

${ }^{88}$ Ministry of Environment, Sweden, 2014. Sweden's Sixth National Communication on Climate change. (National Inventory Report). Ds 2014:11. 
7.6 Norway $^{89}$

\subsubsection{Characterization of the country}

Figure 1: NorBalWet countries covered in this report (grey); Norway (dark grey)

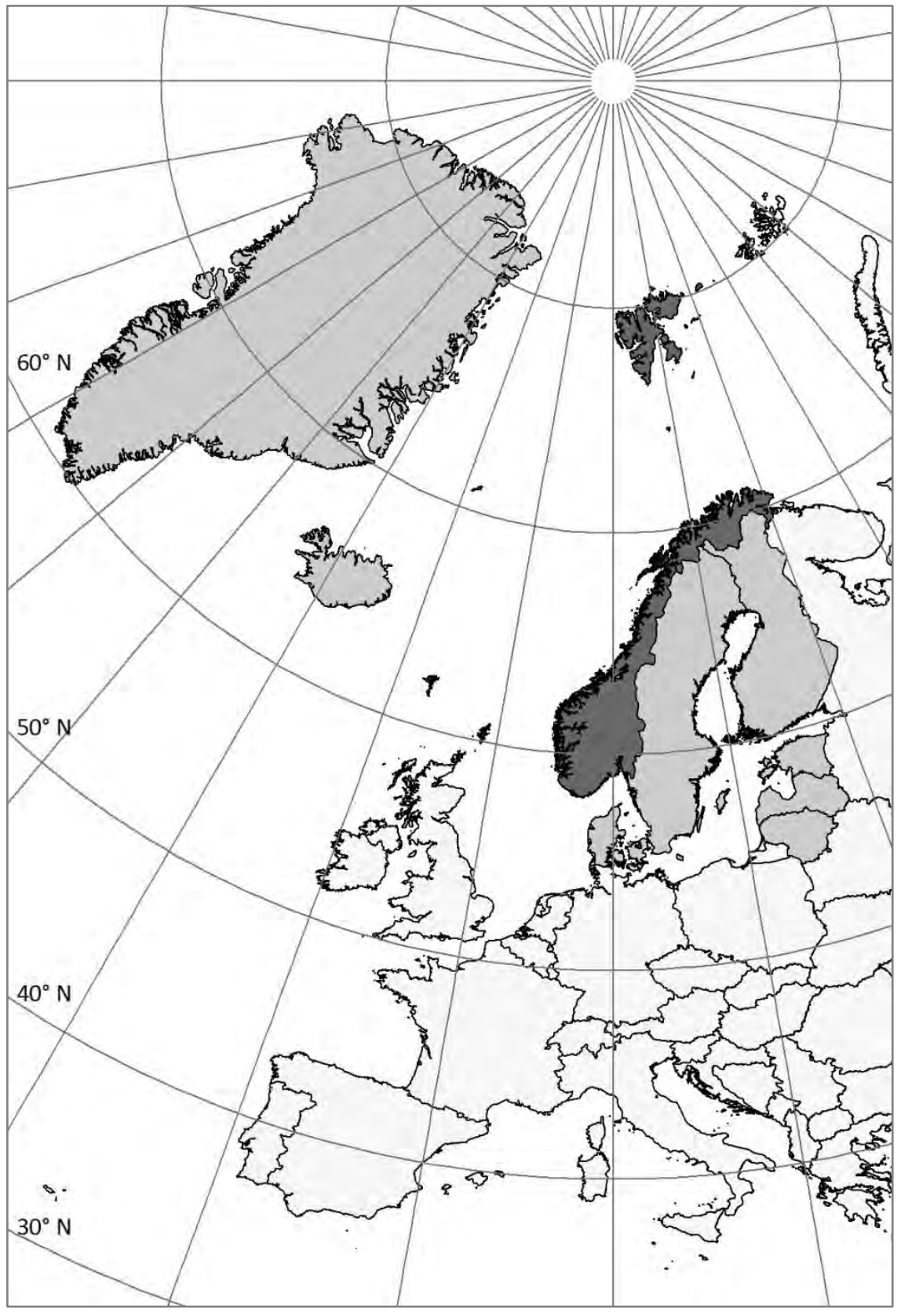

${ }^{89}$ This analysis does not include Svalbard and Jan Mayen. 
Norway (Figure 1) is located in Northwest-Europe between $57^{\circ} 58^{\prime}$ and $71^{\circ} 11^{\prime} \mathrm{N}$, and $4^{\circ} 56^{\prime}$ and $31^{\circ} 30^{\prime}$ E. $32 \%$ of the country lies below 300 m.a.s.l. and $20 \%$ is higher than 900 m.a.s.l. The geological history is complex: Precambrian rocks (600 to 425 mill. years) form the basement and were deformed during the main Caledonian (420 to 390 mill. years). This terrain was subsequently eroded and afterwards rejuvenated to form the present Scandinavian mountain chain (Alpine orogeny; some 55 million years ago). The most common bedrock is siliceous, giving poor (acidic) mineral soils, which cover large parts of the country. More easily weathered bedrock covers extensive areas in central and northern Norway. Some small areas of limestone and shale are found in the South, notably in the Oslo region (Moen 2015).

The climate varies considerably due to the long distance both SouthNorth and West-East, the influence of the Gulfstream with westerly warm winds, and the marked relief. The warmest region is along the southern coast with an average annual temperature of 7-8 ${ }^{\circ} \mathrm{C}$. Coldest areas are in the high altitudes and the North with an average annual temperature below $-4^{\circ} \mathrm{C}$. The coastline from Lindesnes to Lofoten has monthly winter means above $0^{\circ} \mathrm{C}$. Inland valleys are influenced by temperature inversions in winter with January mean temperatures below $-10{ }^{\circ} \mathrm{C}$ in large areas (Moen 2015). Precipitation is highest on the west side of high mountains with normally $>2,000 \mathrm{~mm}$ annually and decreases from western Norway to the East and North. Large areas in eastern and north-eastern Norway have less than $500 \mathrm{~mm}$ of precipitation (even less than $300 \mathrm{~mm}$; Moen 1999).

\subsubsection{Peatland diversity}

"Myr" in Norwegian is defined as an area with a high groundwater-table and a potentially peat forming vegetation. Myr is a somewhat broader concept than the international definition of mire, as a mire is always a peatland (§ 2.1., fig. 2.1) whereas a myr may also exist without or with only a shallow layer of peat. Peat (torv) consists of the organic remnants accumulated in mire systems, and a peatland (torvmark) is an area covered by peat with a minimum thickness of $30 \mathrm{~cm}$ (Moen 2015). Ecological classification of mires in Norway follows the Fennoscandian tradition (e.g. 
Sjörs 1948, Moen 1995), separating between ombrotrophic mire (bog; nedbørmyr) and minerotrophic mire (fen; jordvannmyr, ${ }^{90}$ Moen 2015).

Next to the morphologic mire types mentioned for Finland, in Norway also typical Atlantic peatlands occur, including Atlantic raised bog (atlantisk høgmyr), Ridge raised bog (kanthøgmyr) and blanket bog (terrengekkende myr).

The mire vegetation is differentiated in three local vegetational gradients: poor-rich (fattig-rik), expance-margin (myrflate-myrkant) and hummock-mud bottom (tue-løsbunn).

Within the 25 mire and spring vegetation units described for Norway large differences exists regarding species richness. Ombrotrophic mires carry some 20 species of vascular plants (some more in Oceanic areas), whereas more than 200 species can be found in rich fens (Moen et al. 2010). Såstad \& Moen (1995) listed 372 mire species with common occurrence in mires of central Norway, and all together in Norway at least 400 species of vascular plants and some 300 species of bryophytes occur in mire vegetation (Moen, pers. comm.).

In the lowlands of southern Norway a large proportion of the mires have been drained and in many areas (e.g. counties Vestfold, Akershus and Østfold) virtually all larger unprotected mires are destroyed or seriously impacted (Moen et al. 2010). About 15\% of the threatened and near threatened species in Norway have a significant proportion (> 20\%) of their populations in mires, springs and flood plains. The vast majority of them are bound to rich fens, of which only small areas are left untouched. The spring habitats have likewise been extensively affected by ditching and development (Moen et al. 2010).

The Nature Index ("NI", Nybø et al. 2011) measures the state and development of biodiversity in the major ecosystems on a scale from 1 (reference state) to 0 (very poor state). The mires and wetlands in southwestern and southern Norway were found to be in a poor state (NI $=0.51$ for both regions; Figure 1). The conditions in open lowland mire are most worrying since this ecosystem covers only a small area and is in a poor state. Many areas are becoming overgrown and both extent and quality of the remaining areas are declining (Nybø et al. 2011).

${ }^{90}$ Also called nedbørsmyr and jordvannsmyr. 
Figure 1: State of the biodiversity in Norwegian mires and wetlands in 2010, as measured by the Nature Index

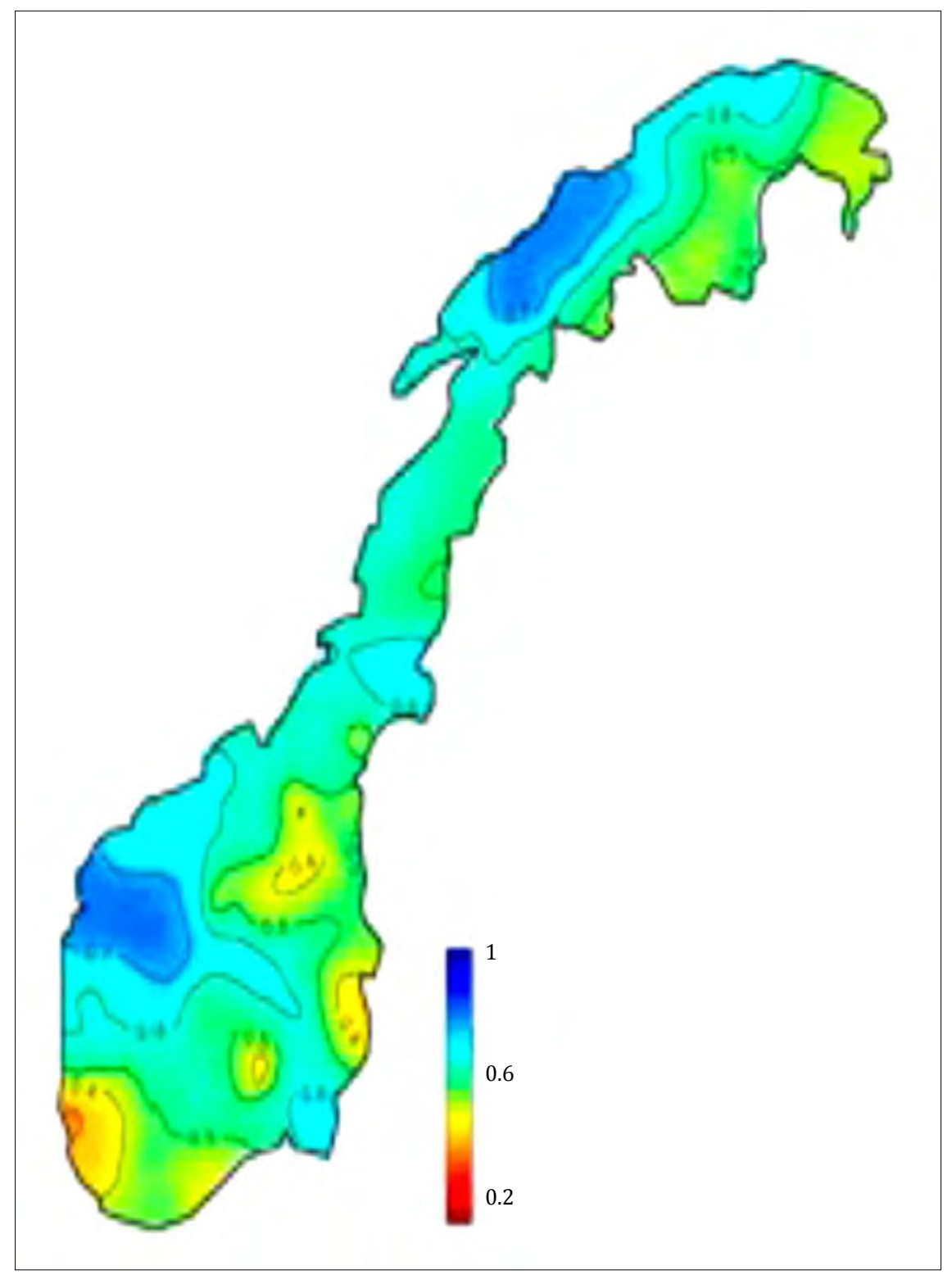

(Nybø et al. 2011; 1 = reference state; 0 = very poor state)

\subsubsection{Peatland degradation}

The first drainage of peatlands took place for agriculture around 1750 and for forestry around 1860. In 1921 peatlands drained for agriculture covered $110.0 \times 10^{3}$ ha, in $1943130 \times 10^{3}$ ha, and in $1963150 \times 10^{3}$ ha (Moen 2015). The area of organic soils drained for forestry increased in 
the 1950 s to a peak of approximately $13.0 \times 10^{3}$ ha drained annually in the early 1960s. Since then the rate has been drastically reduced, and for the period 2000-2010 it amounted to approximately $0.2 \times 10^{3}$ ha per year (NIS Norway 2014). Since 2007 the establishment of drainage ditches on organic soils with the aim of forest production is prohibited by law (Moen 2015).

Peat extraction for fuel started more than 1000 years ago and has affected large areas of mire, particularly along the treeless coast of Norway. Additionally, in thousands of small households peat was used as a fuel, which influenced a large number of small and larger mires (Moen 2015). According to NIS Norway (2014), there are $0.3 \times 10^{3}$ ha of active peat extraction sites in Norway (which probably is an underestimation and excludes the already abandoned peat extraction sites), and between 220,000 and $300,000 \mathrm{~m}^{3}$ of peat is extracted per year.

All together about $200.0 \times 10^{3}$ ha of mire ${ }^{91}$ has been drained for agriculture and more than $400.0 \times 10^{3}$ ha for forestry (Moen 2015). Nowadays more than $30 \%$ of the original mire area below the coniferous forest limit (mainly in the nemoral, boreonemoral, south boreal and middle boreal vegetation zones) has been drained, whereas the mire area influenced by ditches is much larger. Nearly all larger mires in the lowland districts have been affected by reclamation (Moen 2015).

\subsubsection{Current peatland: location, extent, status, land use and greenhouse gas emissions}

\section{Material and Methods}

To assess the location and extent of Norwegian mires, we used:

- the "myr" vector data from Staatens Kartverk (http://www.statkart.no/). This data set comprises areas of "myr" and according to Arvid Lillethun (pers. comm.), "there might be underrepresentation in coastal open areas and other areas." The dataset does not include information about peatland types.

To assess land use on organic soils, we used:

${ }^{91}$ Mire in the sense of the Norwegian "myr". 
- the "raster dataset of agriculturally used organic soils" (Histosols and soils with a Histic horizon ${ }^{92}$ ) from the Norsk institutt for skog og landskap (http://www.skogoglandskap.no/).

The total data on agricultural land (mineral and organic) is calculated from a database obtained from the farmer's application for subsidies (pers. comm. Arne Grønlund). Of this total agricultural land, approximately $50 \%$ is already soil mapped by the Norwegian Forest and Landscape Institute. As this "raster dataset of agriculturally used organic soils" only covers the organic soils out of this $50 \%$ already soil mapped agricultural area, it substantially underestimates the extent of agriculturally drained organic soils. This dataset is also part of the data used for area estimation in NIS Norway (2014, see below).

Geospatial data on forested peatlands and peat extraction sites do not exist in a format that is available to this project. Therefore, we used additionally:

- the National Inventory Submission of Greenhouse Gases to the UNFCCC for estimating emissions from drained organic soils (NIS Norway 201493).

The NIS Norway (2014) provides information on the distribution and use of drained organic soils partly on the basis of the Norwegian National Forest Inventory (NFI). The NFI, operated by the Norwegian Forest and Landscape Institute, assesses every year $1 / 5$ th of a set of plots that are evenly distributed across the country. The regular inventory cycles started in 1919 with the 10th cycle performed over the period 2010-2014.

The data on agricultural land (mineral and organic) in the NIS are calculated from the above mentioned subsidy database. For the non-soil maps less detailed land use maps, which indicate cultivated peatlands, were used (pers. comm. Arnold Arnoldussen). These three datasets were used to arrive at an estimate for drained organic soil used for agriculture in NIS Norway (2014). Compared with the "raster dataset of agriculturally used organic soils" (Histosols and soils with a Histic horizon) of the

\footnotetext{
92 http://ticri.inpl-nancy.fr/urban_soils.en/index.php/Histic_horizon_\%28WRB\%29

93 The National Inventory Submission ('NIS') consists of the National Inventory Report ('NIR') and the Common Reporting Format ('CRF'). Since both the NIR and the CRF were used, we further refer to the complete National Inventory Submission of Norway (NIS Norway 2014).
} 
Norsk institutt for skog og landskap (see above), the area estimate in NIS Norway (2014) is much more complete.

Since the area reported for Cropland and Grassland in NIS Norway (2014) seem to be underestimated, we additionally considered area data on drained organic soils for Cropland and Grassland from:

- the Statistics Division of the Food and Agriculture Organization of the United Nations (FAOStat), which can be extracted at: http://faostat3. fao.org/faostat-gateway/go/to/download/G1/GV/E. The methodology of data assessment is available at: http://faostat3.fao.org/faostatdownload-js/PDF/EN/GV.pdf.

For error analysis of the available GIS raster datasets (see above), we visually checked the data with regard to dimension and accuracy of borders against open layer satellite images of the World Imagery layer (Esri ArcGIS) for five randomly selected areas with a diameter of $10 \mathrm{~km}$. The "myr" dataset describes very accurately the limits of (predominantly open) wetlands with potentially peat accumulating vegetation. The dataset "raster dataset of agriculturally used organic soils" underestimates the extent of agriculturally drained organic soils, as it has e.g. a patchy appearance in valley bottoms. This is probably caused be the exclusion of fallows, e.g. areas outside the agricultural parcels for which subsidy had been applied (see above).

Emissions were re-calculated using the IPCC (2014) default emission factors for $\mathrm{CO}_{2}$ for the Boreal climate/vegetation zone (Table 2). However, the Tier 2 country specific emission factors for $\mathrm{CO}_{2}$ of NIS Norway (2014) seem to be more reliable for Norway than the IPCC Tier 1 values (Table 2).

Thus, for emission calculation according to the area data for Cropland on organic soil from FAOStat we applied the Tier 2 emission factors as reported in NIS Norway (2014).

Carbon loss from DOC (Dissolved Organic Carbon) is not included in this study.

Peat carbon stocks were derived from Joosten (2009).

\section{Results}

The GIS analysis shows that Norwegian "myr" covers in total 1,897.2 x $10^{3}$ ha (Table 1). "Myr" is distinctly unevenly distributed and mainly occurs in the southern and central provinces Oppland, Hedmark, Sør-Trøndelag, Nord-Trøndelag and in the Finnmark in the far North (Figure 2). In terms of altitudes in south-eastern Norway the largest area is found in the middle and northern boreal zones, where "myr" covers $20-40 \%$ of several counties (Moen et al. 2010). 
According to our analysis of the "raster dataset of agriculturally used organic soils," Histosols and Histic soils (= organic soils) drained and used for agriculture cover $21.2 \times 10^{3}$ ha, which must be a considerable underestimate. One reason is that the soil mapping until now covers only approximately $50 \%$ of the total agricultural area of Norway (Roar Lågbu, pers. comm., see Material and Methods).

According to Roar Lågbu (pers. comm.) the area of agriculturally used Histosol and Soils with Histic horizon in Norway is estimated to cover totally $7.3 \%$ of the total agricultural area $\left(1,042.0 \times 10^{3}\right.$ ha $\left.{ }^{94}\right)$ of agricultural land. This would imply $76.1 \times 10^{3}$ ha of drained organic soil for agriculture, which is fairly in line with the area given in the NIS Norway (2014) for Cropland and Grassland together (70.9 x 10 3 ha, Table 2). The extent of the total agricultural area in Norway, however, was elaborated through subsidy application schemes (see Material and Methods), which makes it plausible that fallow drained organic soils are not included. The GIS on Histosols and Histic soils we used (which is also integrated in the reporting of the agriculturally used drained organic soils in NIS Norway 2014, see Material and Methods), indeed shows artificial borders (of e.g. ownership or subsidy receipt?) and a fragmented representation, which also points at incompleteness of the inventory.

This observation could be supported by FAOstat, 95 which gives for Norway an area of drained Cropland of $116.5 \times 10^{3}$ ha which is considerably larger than the $66.4 \times 10^{3}$ ha in NIS Norway (2014). The estimate for drained organic soil for Grassland from FAOStat of $124.0 \times 10^{3}$ ha (Table 3) is rather an overestimate, whereas the $4.5 \times 10^{3}$ ha in NIS Norway (2014, Table 2) might rather be an underestimation.

\begin{tabular}{|c|c|c|c|}
\hline Soil type & $\begin{array}{r}\text { Area } \\
\left(10^{3} \mathrm{ha}\right)\end{array}$ & $\begin{array}{r}\text { Emission factor } \\
\left.\text { (t CO } \mathrm{C}_{2} / \mathrm{ha} / \mathrm{yr}\right)\end{array}$ & $\begin{array}{r}\text { Emissions } \\
(\mathrm{Mt} \mathrm{CO} / \mathrm{yr})\end{array}$ \\
\hline Undrained mires $(\mathrm{myr})^{1)}$ & $1,876.0$ & \pm 0 & \pm 0 \\
\hline Organic soil, drained for agriculture & 21.2 & $24.9^{96}$ & 0.53 \\
\hline$\sum$ Total & $1,897.2$ & & 0.53 \\
\hline
\end{tabular}

${ }^{1)}$ Open areas with high groundwater table and potentially peat forming vegetation.

\footnotetext{
${ }^{94} \mathrm{http} / / /$ www.tradingeconomics.com/norway/agricultural-land-sq-km-wb-data.html

95 http://faostat.fao.org/site/711/default.aspx\#ancor

95 This is the $\emptyset$ of the default emission factors (EF) "Cropland, drained" and EF “Grassland, drained" from IPCC (2014).
} 
Figure 2: Location and total extent of Norwegian "myr" and drained organic soils (Histosol and soils with a Histic horizon) used for agriculture (our GIS analysis, see Material and Methods).

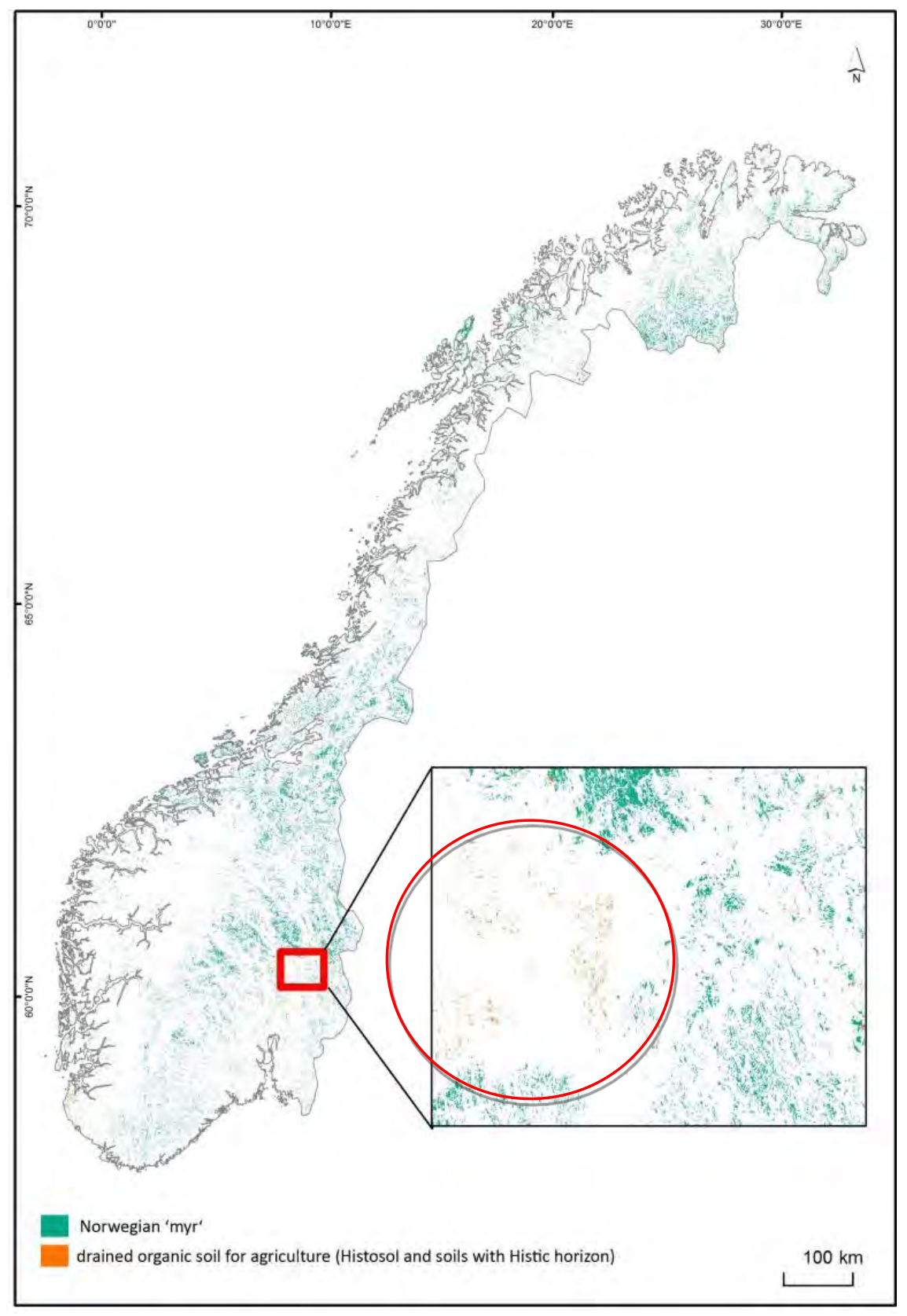

Precise spatial-explicit data on the peatland area of Norway seem not to be available. 
According to the National Inventory Submission for Norway (NIS Norway 2014) 4,571.6 x $10^{3}$ ha of organic soils exists, including 3,777.9 $\times 10^{3}$ ha undrained "wooded mire". "Wooded mire" is a subgroup of the group "other woodland" which has been defined under category Forest Land, but is reported under category Wetlands. ${ }^{97}$ "Wooded mire" is defined as land with sparse tree cover with crown cover between 5 and $10 \%$ and that hosts trees that have the potential to reach a height of $5 \mathrm{~m}$, or with a combined cover of shrubs, bushes and trees above $10 \%$, and with an organic soil depth $>40 \mathrm{~cm}$ (NIS Norway 2014). Beside this, $312.7 \times 10^{3}$ ha organic soil drained for various purposes were reported $\left(241.4 \times 10^{3}\right.$ ha of Forest Land, $66.4 \times 10^{3}$ ha of Cropland, $4.5 \times 10^{3}$ ha of Grassland, and $0.3 \times 10^{3}$ ha used for Peat extraction, Table 2, Table 3). Additionally, NIS Norway (2014) mentions a subgroup "Mire without tree cover" belonging to category Wetlands (Table 7.10), but unfortunately there are no area data disclosed.

On Forest Land organic soils are defined as having an organic layer $>40 \mathrm{~cm}$, whereas on Cropland the organic layer has to be $>30 \mathrm{~cm}$. These differences in approaches may lead to reporting inconsistencies in case of changes in land use category (e.g. when Cropland is afforested or Forest land is converted to Cropland). The forest definition may also imply that the peatland area of Norway ( $>30 \mathrm{~cm}$ peat layer) may even exceed $4,571.6 \times 10^{3}$ ha. According to NIS Norway (2014) Wetlands cover $12 \%$ of the country, which would, based on a total area of Norway of 38,525.2 x $10^{3}$ ha, ${ }^{98}$ result in $4,623.0 \times 10^{3}$ ha of Wetlands.

The substantially underestimated $21.2 \times 10^{3}$ ha of organic soils drained for agriculture from the "raster dataset of agriculturally used organic soils" (see Material and Methods) would emit $0.5 \mathrm{Mt} \mathrm{CO}_{2}$ per year (Table 1). According to the NIS Norway (2014) the drained organic soils lead to 3.3 Mt of annual $\mathrm{CO}_{2}$ emissions (Table 2). With the new IPCC (2014) Tier 1 default emission factors for $\mathrm{CO}_{2}$ this value would be $2.6 \mathrm{Mt} \mathrm{CO}_{2}$, but the Tier 2 country specific emission factors for $\mathrm{CO}_{2}$ used in the NIS Norway (2014) seem to be more reliable than the tier 1 default values.

If we consider the FAOstat area data for Cropland as realistic (the FAOstat data for Grassland seem to be an overestimation), the annual $\mathrm{CO}_{2}$ emissions from drained organic soils in Norway would be $6.3 \mathrm{Mt}$ (when using the Tier 2 emission factors of NIS Norway 2014; Table 4),

\footnotetext{
97 "Wooded mire" would according to Norway's national definition be classified as forest, if the requirements of the international forest definition are met. When this is not the case, such areas are considered under Wetlands remaining Wetlands as the subgroup “wooded mire' (NIS Norway 2014).

$98 \mathrm{http}: / /$ en.wikipedia.org/wiki/Norway\#Geography
} 
the area of drained organic soils would be $434.8 \times 10^{3}$ ha, and the total area of organic soils $4,621.7 \times 10^{3}$ ha (Table 4 ).

To assess the total drainage affected areas, all ditches could be mapped and a drainage impact zone of $200 \mathrm{~m}$ applied (cf. NIS Iceland 2014). Figure 3 and Table 5 give an overview of the location and extent of agriculturally used, drained organic soils in Norway.

Table 2: Drained organic soil areas, land use types and associated $\mathrm{CO}_{2}$ emissions. Left part of the table: as reported in the National Inventory Report of Norway (NIS Norway 2014) to the UNFCCC. Right part: recalculation of emissions with the new IPCC (2014) default emission factors for $\mathrm{CO}_{2}$

\begin{tabular}{|c|c|c|c|c|c|c|c|}
\hline \multirow{2}{*}{$\begin{array}{l}\text { Norway } \\
\text { UNFCCC Land Use } \\
\text { Category }\end{array}$} & \multicolumn{3}{|c|}{ National Inventory Submission 2014} & \multirow[b]{2}{*}{$\begin{array}{r}\text { EF } \\
\text { TIER }\end{array}$} & \multirow[b]{2}{*}{$\begin{array}{r}\text { Uncer- } \\
\text { tainty } \\
\text { EF \% }\end{array}$} & \multicolumn{2}{|c|}{$\begin{array}{l}\text { Recalculated according to } \\
\text { IPCC (2014) }\end{array}$} \\
\hline & $\begin{array}{r}\text { Area of } \\
\text { drained } \\
\text { organic soil } \\
\left(10^{3} \text { ha }\right)\end{array}$ & $\begin{array}{r}\text { Net carbon } \\
\text { stock change } \\
\text { per area } \\
\left(\mathrm{t} \mathrm{CO}_{2} / \mathrm{ha} / \mathrm{yr}\right)\end{array}$ & $\begin{array}{r}\text { Emissions } \\
(\mathrm{Mt} \mathrm{CO} / \mathrm{yr})\end{array}$ & & & $\begin{array}{r}\text { Net carbon } \\
\text { stock change } \\
\text { per area } \\
\left(\mathrm{t} \mathrm{CO}_{2} / \mathrm{ha} / \mathrm{yr}\right)\end{array}$ & $\begin{array}{r}\text { Emissions } \\
(\mathrm{Mt} \mathrm{CO} / \mathrm{yr})\end{array}$ \\
\hline $\begin{array}{l}\text { Forest Land remaining } \\
\text { Forest Land }\end{array}$ & & & & 2 & & & \\
\hline Drained organic soil & 241.4 & 7.0 & 1.55 & & 45 & 2.2 & 0.52 \\
\hline Norway-NFI & 474.6 & \pm 0 & & & & \pm 0 & \\
\hline $\begin{array}{l}\text { Cropland converted to } \\
\text { Forest Land }\end{array}$ & 1.5 & 7.0 & 0.01 & & 149 & 2.2 & 0.00 \\
\hline $\begin{array}{l}\text { Grassland converted } \\
\text { to Forest Land }\end{array}$ & 1.8 & 7.0 & 0.01 & & & 2.2 & 0.00 \\
\hline $\begin{array}{l}\text { Wetlands converted to } \\
\text { Forest Land }\end{array}$ & 2.5 & 7.0 & 0.02 & & 125 & 2.2 & 0.01 \\
\hline $\begin{array}{l}\text { Settlement converted } \\
\text { to Forest Land }\end{array}$ & 0.7 & 7.0 & 0.01 & & 205 & 2.2 & 0.00 \\
\hline$\sum$ FOREST LAND & 722.5 & & 1.59 & & & & 0.54 \\
\hline $\begin{array}{l}\text { Cropland remaining } \\
\text { Cropland }\end{array}$ & 60.5 & 24.5 & 1.48 & 2 & 100 & 29.0 & 1.75 \\
\hline $\begin{array}{l}\text { Forest Land converted } \\
\text { to Cropland }\end{array}$ & 1.6 & 24.5 & 0.04 & & 159 & 29.0 & 0.05 \\
\hline $\begin{array}{l}\text { Grassland converted } \\
\text { to Cropland }\end{array}$ & 1.0 & 24.5 & 0.02 & & 174 & 29.0 & 0.03 \\
\hline $\begin{array}{l}\text { Wetlands converted to } \\
\text { Cropland }\end{array}$ & 3.2 & 24.5 & 0.08 & & 145 & 29.0 & 0.09 \\
\hline $\begin{array}{l}\text { Settlement converted } \\
\text { to Cropland }\end{array}$ & 0.1 & 24.5 & 0.00 & & 174 & 29.0 & 0.00 \\
\hline$\Sigma$ CROPLAND & 66.4 & & 1.62 & & & & 1.92 \\
\hline $\begin{array}{l}\text { Grassland remaining } \\
\text { Grassland }\end{array}$ & 2.7 & 24.5 & 0.07 & 2 & 100 & 20.9 & 0.06 \\
\hline
\end{tabular}




\begin{tabular}{|c|c|c|c|c|c|c|c|}
\hline \multirow{2}{*}{$\begin{array}{l}\text { Norway } \\
\text { UNFCCC Land Use } \\
\text { Category }\end{array}$} & \multicolumn{4}{|c|}{ National Inventory Submission 2014} & \multirow[b]{2}{*}{$\begin{array}{r}\text { Uncer- } \\
\text { tainty } \\
\text { EF \% }\end{array}$} & \multicolumn{2}{|c|}{$\begin{array}{l}\text { Recalculated according to } \\
\text { IPCC }(2014)^{1)}\end{array}$} \\
\hline & $\begin{array}{r}\text { Area of } \\
\text { drained } \\
\text { organic soil } \\
\left(10^{3} \mathrm{ha}\right)\end{array}$ & $\begin{array}{r}\text { Net carbon } \\
\text { stock change } \\
\text { per area } \\
\text { (t } \mathrm{CO}_{2} / \mathrm{ha} / \mathrm{yr} \text { ) }\end{array}$ & $\begin{array}{r}\text { Emissions } \\
(\mathrm{Mt} \mathrm{CO} / \mathrm{yr})\end{array}$ & $\begin{array}{r}\text { EF } \\
\text { TIER }\end{array}$ & & $\begin{array}{r}\text { Net carbon } \\
\text { stock change } \\
\text { per area } \\
\left(\mathrm{t} \mathrm{CO}_{2} / \mathrm{ha} / \mathrm{yr}\right)\end{array}$ & $\begin{array}{l}\text { Emissions } \\
(\mathrm{Mt} \mathrm{CO} / \mathrm{yr})\end{array}$ \\
\hline $\begin{array}{l}\text { Forest Land converted } \\
\text { to Grassland }\end{array}$ & 1.3 & 24.5 & 0.03 & & 225 & 20.9 & 0.03 \\
\hline $\begin{array}{l}\text { Wetlands converted to } \\
\text { Grassland }\end{array}$ & 0.6 & 24.5 & 0.01 & & 224 & 20.9 & 0.01 \\
\hline$\Sigma$ GRASSLAND & 4.5 & & 0.11 & & & & 0.09 \\
\hline \multicolumn{8}{|l|}{ Wetlands remaining } \\
\hline Peat extraction & 0.3 & 10.0 & 0.00 & 2 & 100 & 10.3 & 0.00 \\
\hline Wooded mire & $3,777.9$ & \pm 0 & & & & \pm 0 & \\
\hline$\Sigma$ WETLANDS & $3,778.2$ & & 0.00 & & & & 0.00 \\
\hline $\begin{array}{l}\sum \text { TOTAL ORGANIC } \\
\text { SOIL DRAINED }\end{array}$ & 312.7 & & 3.33 & & & & 2.56 \\
\hline $\begin{array}{l}\sum \text { TOTAL ORGANIC } \\
\text { SOIL }\end{array}$ & $4,571.3$ & & & & & & \\
\hline
\end{tabular}

1) Mind that the Tier 2 country specific emission factors for $\mathrm{CO}_{2}$ of NIS Norway (2014) seem to be more reliable for Norway than the IPCC Tier 1 values.

Figure 3: Areas of drained, agriculturally used Histosols and soils with Histic horizon in Norway (red; only 50\% of the total agricultural land mapped so far; data from the Norsk institutt for skog og landskap)

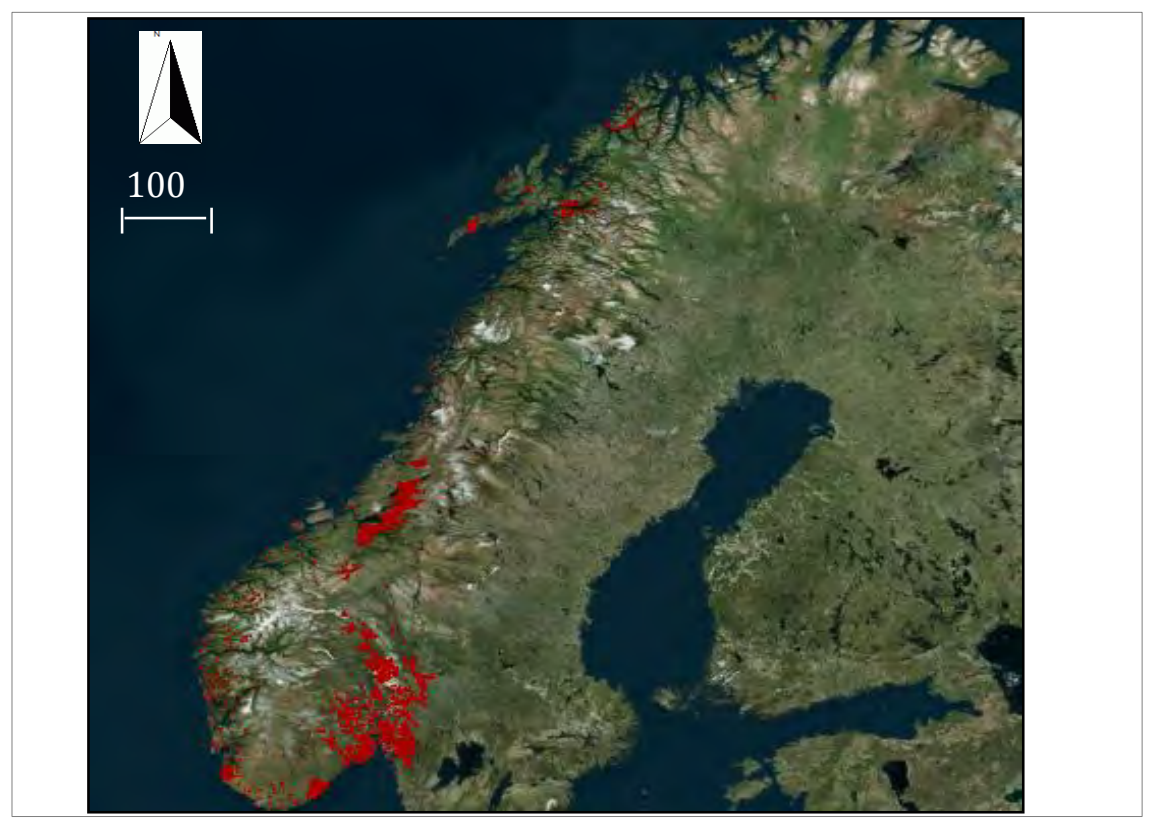


Table 3: Area of wetland, "myr" and organic soil in Norway (various sources). Only the land use types used in NIS Norway (2014) fully correspond to the UNFCCC/IPCC land use categories

\begin{tabular}{|c|c|c|c|c|}
\hline \multirow[t]{2}{*}{ Drainage status and land use type } & \multicolumn{4}{|c|}{ Area per land use type $\left(10^{3} \mathrm{ha}\right)$} \\
\hline & $\begin{array}{l}\text { Our GIS } \\
\text { analysis }\end{array}$ & $\begin{array}{r}\text { NIS Norway } \\
\text { (2014) }\end{array}$ & $\begin{array}{l}\text { Moen } \\
(2015)\end{array}$ & FAOStat \\
\hline "myr"1) drained, & & & $>600.0$ & \\
\hline "myr" ${ }^{11}$, undrained & $1,876.0$ & & $\sim 2,000.0$ & \\
\hline$\sum$ total "myr" & & & $\sim 2,600.0$ & \\
\hline organic soil, drained Forest Land & & 241.4 & $>400.0$ & \\
\hline organic soil, drained agriculture & $21.2^{3)}$ & & 200.0 & \\
\hline organic soil, drained Cropland ${ }^{4)}$ & & $66.4^{6)}$ & & 116.5 \\
\hline organic soil, drained Grassland & & 4.5 & & $124.0^{7)}$ \\
\hline organic soil, Peat extraction & & 0.3 & & \\
\hline$\sum$ subtotal organic soil, drained & & 312.7 & & 240.5 \\
\hline organic soil, undrained Forest Land ${ }^{8)}$ & & 474.6 & & \\
\hline organic soil, undrained wooded mire ${ }^{5)}$ & & $3,777.8$ & & \\
\hline$\sum$ total organic soil & & $4,571.6$ & & \\
\hline
\end{tabular}

${ }^{1)}$ Areas with high water levels and potentially peat forming vegetation (cf. Moen 2015).

2) Dataset "raster dataset of agriculturally used organic soils" which includes Histosol and soils with a Histic horizon mapped for $50 \%$ of the total agricultural area of Norway so far (see Material and Methods).

${ }^{3)}$ Considerably underestimated, due to the only $50 \%$ coverage of the GIS dataset "raster dataset of agriculturally used organic soils" (Histosol and soils with Histic horizon), and due to the application of subsidy schemes to assess the total agricultural area of Norway (see Material and Methods).

4) "The Norwegian definition of Histosols (organic soils) for Cropland is soils with $>10 \% \mathrm{C}$ in the topsoil layer (0-30 cm)" (NIS Norway 2014).

5) Category: "wooded mire". "...Other wooded land is defined as land with sparse tree cover with crown cover between 5 and $10 \%$ and hosts trees that have the potential to reach a height of $5 \mathrm{~m}$, or with a combined cover of shrubs, bushes and trees above $10 \%$. It is classified as other wood land if the soil is classified as mineral soil and wooded mire if the organic soil is $>40 \mathrm{~cm}$ deep." (NIS Norway 2014)

6) Probably underestimated due to the application of subsidy schemes to assess the total agricultural area in Norway and thus, the exclusion of e.g. fallows (see Material and Methods).

${ }^{7)}$ Seem to be overestimated.

${ }^{8)}$ Subcategory "Norway-NFI" in CRF file of NIS Norway.

Table 4: Data integration on organic soil areas, land use types and associated $\mathrm{CO}_{2}$ emissions in Norway. Forest Land, Grassland, Peat extraction and Wooded mire: as reported in the National Inventory Submission of Norway to the UNFCCC (NIS Norway 2014); Cropland as available from FAOStat, ${ }^{99}$ calculation of emissions with Tier 2 emission factors from NIS Norway (2014)

\begin{tabular}{lrrr}
\multicolumn{1}{c}{$\begin{array}{l}\text { Land use type } \\
\text { Area of organic } \\
\text { soil } \\
\left(\mathbf{1 0}^{\mathbf{3}} \mathbf{~ h a )}\right.\end{array}$} & $\begin{array}{r}\text { Net carbon stock } \\
\text { change per area } \\
(\mathbf{t ~ C O} / \mathbf{h a} / \mathbf{y r})\end{array}$ & $\begin{array}{r}\text { Emissions } \\
\left.\text { (Mt } \mathbf{C O}_{2} / \mathbf{y r}\right)\end{array}$ \\
organic soil, drained Forest Land & 312.7 & 7.0 & 3.33 \\
organic soil, drained Cropland & 116.5 & 24.5 & 2.85 \\
organic soil, drained Grassland & 4.5 & 24.5 & 0.11 \\
organic soil, drained Peat extraction & 0.3 & 10.0 & 0.00 \\
$\sum$ total drained organic soil & 434.8 & & 6.26 \\
organic soil, undrained wooded mire & $3,777.8$ & & \\
$\sum$ total organic soil & $4,621.1$ & & \\
\hline
\end{tabular}

${ }^{99}$ Available at: http://faostat.fao.org/site/739/default.aspx\#ancor 
The peat resources of Norway were estimated to be 2,230 Mt Carbon in 2008 (Joosten 2009).

Considering the proportion of drained peatland and the associated carbon losses (Table 2) in comparison with the Carbon sequestration capacity of undrained mires (ca. $0.3 \mathrm{t} \mathrm{C} / \mathrm{ha} / \mathrm{yr}$; Clymo et al. 1998), the peat carbon stock of Norway is very probably decreasing.

\begin{tabular}{|c|c|c|c|}
\hline Municipality & Organic soil drained for $\left(10^{3} \mathrm{ha}\right)$ & Municipality & Organic soil drained for $\left(10^{3} \mathrm{ha}\right)$ \\
\hline Sortland & 1.16 & Oppdal & 0.76 \\
\hline Vestvåg $\varnothing y$ & 1.12 & Lund & 0.70 \\
\hline $\operatorname{Rad} \varnothing y$ & 1.52 & Nærøy & 0.70 \\
\hline Lindås & 1.42 & Stange & 0.67 \\
\hline Smøla & 1.39 & Finnøy & 0.67 \\
\hline Vindafjord & 1.35 & Hjelmeland & 0.67 \\
\hline Eigersund & 1.25 & Rennesøy & 0.64 \\
\hline Bjerkreim & 1.01 & Fræna & 0.60 \\
\hline Hadsel & 0.98 & Farsund & 0.55 \\
\hline Tysvær & 0.93 & Midtre Gauldal & 0.54 \\
\hline Jesdal & 0.90 & Sømna & 0.53 \\
\hline $\mathrm{B} \emptyset$ & 0.88 & Vågan & 0.53 \\
\hline Karmøy & 0.60 & $\varnothing$ ksnes & 0.52 \\
\hline Bømlo & 0.79 & Sveio & 0.51 \\
\hline
\end{tabular}

\subsubsection{Peatland conservation and potentials for peatland restoration/rehabilitation}

The overall Nature Index value for wetlands of Norway is 0.54 (Nybø et al. 2011), but there are considerable geographical variations. One major reason for the low Nature Index value is the previous widespread ditching and draining of lowland peatlands in Norway. Another reason is the tendency of permafrost in mountain palsa mires in Finnmark and Troms to thaw. About $18 \%$ of the total wetlands in Norway are protected under the Nature Diversity Act. Nevertheless, there is a pressing need to establish more protected areas for most wetland habitat types.

Norway has currently no plans of designating new Ramsar sites. There are 63 Ramsar sites in Norway; the last 12 were designated in 2013. Ramsar sites are always protected by law before designation. Review plans exist to identify the inclusion potential of areas bordering Ramsar sites to improve the ecological character and the conservation condition of the area. Other plans review the inclusion of more sub-sites into already designated Ramsar sites. For subsites that are not protected, protection would be the first step.

Approximately nine of the Ramsar sites in Norway consist of large peatlands and are regarded to be important for carbon storage. The next 
updating of the Ramsar site Information Sheets (RIS ${ }^{100}$ ) will consider the use of climate criteria for these sites.

Several ongoing activities in Norway are relevant for this report: The Norwegian Environment Agency prepared a wetland restoration plan for the period 2014-2018. Ten priority sites for restoration were identified based on the following criteria: a) designated Ramsar site, b) occurrence of red listed species or selected habitat types, c) potential for improved ecological character and d) sites prioritized by the county governors. Implementation of these larger restoration projects will cost about 8 million Euros.

- A report with more than 300 proposed restoration sites in wetlands has also been prepared and will be reviewed in order to propose additional sites for restoration. Rewetting of drained wetlands is one restoration activity proposed in the report. One important criterion when identifying additional sites is that the improved ecological status may be achieved with low costs.

- Several restoration activities at smaller scale are already ongoing in Norway and Norway's goal is to restore by 2020 at least half of the wetlands that have been damaged.

\subsubsection{Acknowledgements}

Many thanks to Knut Bjørkelo, Arnold Arnoldussen and Roar Lågbu (Norwegian Forest and Landscape Institute) for extensive discussion about available data and their preparation and delivery; to Asbjørn Moen (Norwegian University of Science and Technology) for support and access to the "myr" data from the Land Mapping Division of the Norwegian Mapping Authority (Staatens Kartverk); and to Arvid Lillethun for their preparation and delivery. For their collaboration within this project we also thank Arne Grønlund (Norwegian Institute for Agricultural and Environmental Research - Bioforsk) and Maja Stade Aarønæs (Norwegian Environment Agency), as well as for her input for Chapter 7.6.5 of this country report.

\footnotetext{
100 http://www.ramsar.org/sites/default/files/documents/pdf/cop11/res/cop11-res08-e-anx1.pdf; https://rsis.ramsar.org/about
} 


\subsubsection{References}

Clymo R.S., Turunen J. \& Tolonen K. (1998). Carbon accumulation in peatland. Oikos 81: 368-388. http://dx.doi.org/10.2307/3547057

Esri ArcGIS: World Imagery. Source: Esri, DigitalGlobe, GeoEye, i-cubed, USDA, USGS, AEX, Getmapping, Aerogrid, IGN, IGP, swisstopo, and the GIS User Community.

IPCC (2014). 2013 Supplement to the 2006 IPCC Guidelines for National Greenhouse Gas Inventories: Wetlands, Hiraishi T., Krug T., Tanabe K., Srivastava N., Baasansuren J., Fukuda M. and Troxler T.G. (eds), published by IPCC, Switzerland.

Joosten $\mathrm{H}$. (2009). The Global Peatland $\mathrm{CO}_{2}$ Picture. Peatland status and drainage associated emissions in all countries of the World. Wetlands International, Ede, $10 \mathrm{p}$. + tables.

Moen A. (ed.), (1995). Regional variation and conservation of mire ecosystems. Gunneria 70: 1-344.

Moen, A. (1999). National Atlas of Norway - Vegetation. Norwegian Mapping Authority, Hønefoss, $200 \mathrm{p}$

Moen A., Dolmen D., Hassel K. \& Ødegaard F. (2010). Mires, springs and flood plains. In: Kålås J.A., Henriksen S., Skjelseth S. \& Viken Å (eds.), Environmental conditions and impacts for Red List Species. Norwegian Biodiversity Information Centre, Trondheim, pp. 51-65.

Moen A. (2015). Norway. In: Joosten, H., Tanneberger, F. \& Moen, A. (eds.), Mires and peatlands of Europe: Status, distribution, and nature conservation. Schweizerbart Science Publishers, Stuttgart.

Nybø S., Certain G. \& Skarpaas O. (2011). The Norwegian Nature Index 2010. DNreport 2011-1.

NIS Norway (2014). Greenhouse Gas Emissions 1990-2012, National Inventory Submission, submitted under the United Nation Framework Convention on Climate Change and the Kyoto Protokoll, 459 p. + Annexes.

Såstad S. \& Moen A. (1995). Classification of mire localities and mire species in central Norway by vegetational regions, Ellenberg species indicator values and climatic data. Gunneria 70: 177-198.

Sjörs H. (1948). Myrvegetation i Bergslagen. [Mire vegetation in Bergslagen, Sweden] Acta Phytogeogr. Suec. 21: 1-299. (In Swedish with English summary) 


\subsection{Iceland}

\subsubsection{Characterization of the country}

Fig. 1: NorBalWet countries covered in this report (grey); Iceland (dark grey)

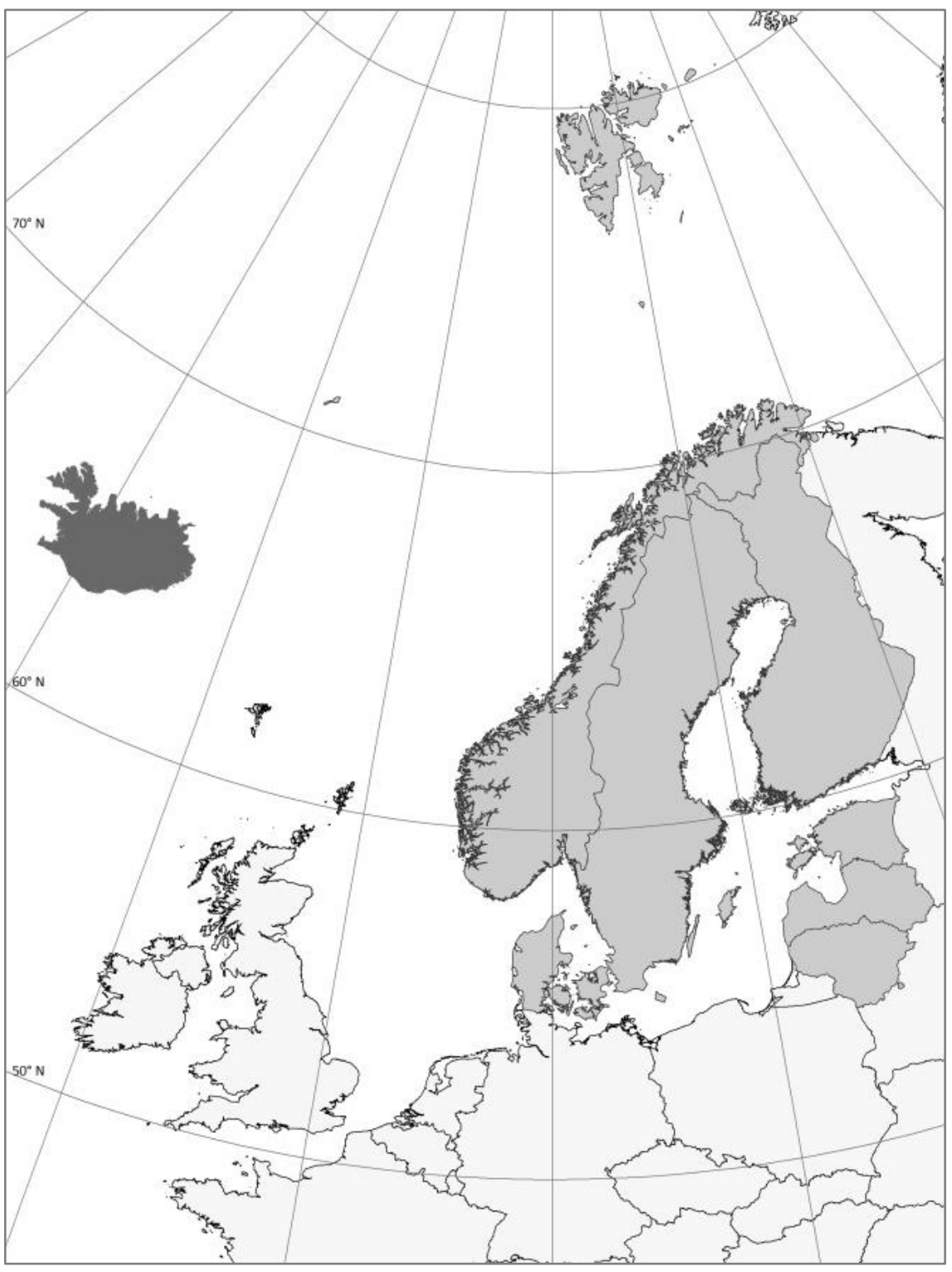

Iceland (Fig. 1) is an oceanic island in the western North Atlantic and covers $103,000 \mathrm{~km}^{2}$. The country stretches from $63^{\circ} 23^{\prime}$ to $66^{\circ} 32^{\prime} \mathrm{N}$ and from $13^{\circ} 30^{\prime}$ to $24^{\circ} 31^{\prime} \mathrm{W}$. Iceland sits on the junction of two diverging 
tectonic plates and is among the world's most volcanically active areas. Glaciers and Holocene lava cover each about $10 \%$ of the land area (Thorhallsdottir et al. 2015). The oldest parts of Iceland (extreme East and West) are Tertiary lava plateaus that Pleistocene glaciers have strongly modified. The land gets progressively younger towards the middle. The unusual geological history and disturbance regime of Iceland influences wetland distribution and types directly and indirectly in several ways (e.g. due to low permeability of the Tertiary bedrock, huge tephra deposition and input of nutrients; Thorhallsdottir et al. 2015).

According to the classification of the biogeographic regions of Europe (European Environmental Agency101), Iceland is placed within the Arctic biogeographical region. Based on a recent circumpolar arctic vegetation map (Walker et al. 2005102), the vast majority of Iceland is classified as non-arctic (thus Boreal). Only the very northernmost tips of the country have been regarded as arctic. In the lowlands the mean July temperatures range from $7.6^{\circ} \mathrm{C}$ in the western fjords to $>10^{\circ} \mathrm{C}$ in the South and West plains and the sheltered valleys of the North and East. Mean annual precipitation is $(1,644) 1600-1700 \mathrm{~mm}$ in the South, but only $400-500$ $\mathrm{mm}$ in the North (Thorhallsdottir et al. 2015). Sporadic permafrost is present in the central highlands.

\subsubsection{Wetland and peatland diversity}

Traditionally, freshwater wetlands in Iceland have been divided into five main types: sloping mires or fens (hallamýri), topogenous fens (flói), alluvial fens and sedge meadows (flæðimýri), palsa mires of the permafrost areas in the central highland (flár) and coastal marshes (sjávarfitjar). Among them the sloping mires, topogenous fens and palsa mires contain considerable amounts of peat/organic soils. Unfortunately, there seem to be no assessment of threatened wetland/peatland habitats available for Iceland, nor a GIS data set addressing different wetland/peatland types.

According to Thórhallsdóttir (2000) sloping mires (usually with 1.5-2.5 m peat) were very common and widespread in the western Fjords of Iceland, the northern and eastern parts as well as in the inland lowlands in the South. Botanically they have been the most di-

\footnotetext{
$101 \mathrm{http} / / /$ www.eea.europa.eu/data-and-maps/figures/biogeographical-regions-in-europe-1

$102 \mathrm{http}$ ///www.geobotany.uaf.edu/library/pubs/WalkerDA2005_jvs_16_267.pdf
} 
verse wetland type, but also the one that has preferentially been drained for agricultural use. Only little parts remain intact.

Topogenous fens are common at the margins of lakes and on flat heathlands. They mainly occur in the basaltic areas in the West, East and North. Topogenous fens are nutrient poor with rather low diversity of vascular plants and low productivity. In parts of Iceland, these fens have been drained and converted to pasture, but have turned out to be much less productive than similarly converted sloping mires (Thórhallsdóttir 2000).

Alluvial fens and sedge meadows are commonly encountered alongside major rivers (especially glacial rivers), estuaries and some lakes in all parts of the country. They are the most productive of the wetlands in Iceland and of higher agricultural importance, but peat accumulation is little or absent even if not drained (Thórhallsdóttir 2000).

\subsubsection{Peatland degradation}

Since Iceland was settled by Scandinavian peoples around AD 874 (landnám), intensive land use in combination with the harsh climate of the Little Ice Age (ca. AD 1250/1500 to 1920) have led to significant degradation of vegetation and soil, including the removal of $\sim 2,500 \mathrm{x}$ $10^{3}$ ha woodland from the lowlands. Tinganelli (2013) provides evidence of the transformation of (at least some) lowland organic soils to mineral soils after the "landnam".

Traditionally, Icelandic houses were built of grass sod and stone and had a turf roof. Wood, peat and dung were burned for cooking (Icelandic houses were not heated). Peatlands were very important for livestock grazing and also as a source of hay. "Grágás", Iceland's oldest legislation (9th to 13th century), contains articles on wetland irrigation. Draining was not part of traditional Icelandic agriculture, but manual low intensity draining was practised over a period of about 60 years from 1880 to 1940 (Thorhallsdottir et al. 2015). In 1942 the first mechanic excavator was imported to Iceland. From that year on large scale draining of wetlands, subsidized by the government, started and grew considerably until reaching its peak in 1968. Over a period of approximately 50 years, more than $31,600 \mathrm{~km}$ of ditches were dug, draining vast areas of wetlands in Iceland, e.g. $97 \%$ of the wetlands in the southern part of Iceland (Institute of Economic Studies 2004). As a result of drainage and cultivation, there are only few undisturbed wetlands left in the lowlands. The lowlands provide fertile hayfields and pasture land for large livestock populations, which keeps a high utilization pressure on these areas 
According to Wald (2012) the wetland area in the southern lowland region (which might host half of the drained organic soil area of Iceland) declined by at least $77 \%$ between 1900-2010 (Figure 2). This area contains $30 \%$ of the ditches of Iceland, but only $1.1 \%$ of the total land area that is protected by national legislation (Wald 2012), which in total covers $19 \%$ of the country. Only few, small areas in the major, previously extensive wetland hosting lowlands of Iceland, are protected. ${ }^{103}$

\section{Figure 2: Schematic representation of land use transition in the southern low- lands in 1900-2010 (from Wald 2012)}

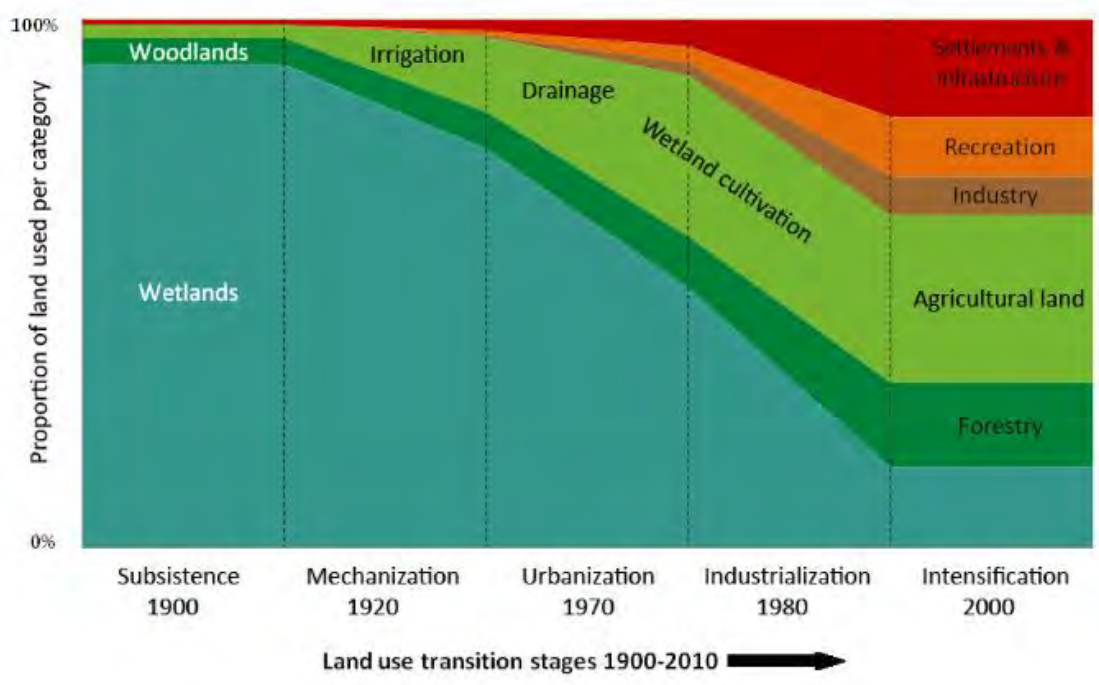

The red list of plants of Iceland (2008) classifies 71 species according to their level of threat (Table 1).

Wetland related plant species account for $46 \%$ of the total threatened plant species of Iceland, illustrating the impact of extensive wetland drainage, utilization and habitat degradation.

103 See map of protected areas in Iceland, available at page 6 of: http://www.vidraedur20092013.is/media/ESB/samningskaflar/27/Habitats-Directive-\%28I\%29.PDF 


\begin{tabular}{|c|c|c|c|}
\hline Category & $\begin{array}{r}\text { Number of species } \\
\text { (all habitats) }\end{array}$ & $\begin{array}{l}\text { Number of species } \\
\text { (wetland habitats) }\end{array}$ & $\begin{array}{r}\% \text { of species } \\
\text { (wetland habitats) }\end{array}$ \\
\hline Regionally extinct (RE) & 1 & 1 & 100 \\
\hline Critically endangered (CE) & 5 & 1 & 20 \\
\hline Endangered (EN) & 8 & 3 & 20 \\
\hline Vulnerable (VU) & 31 & 14 & 45 \\
\hline Near threatened (NT) & 11 & 6 & 54 \\
\hline Least concern (LC) & 15 & 8 & 53 \\
\hline Total & $71^{105}$ & 33 & 46 \\
\hline
\end{tabular}

RE: Primula egaliksensis; CE: Galium palustre; EN: Carex flava, Persicaria amphibia, Spergularia salina; VU: Andromeda polifolia, Carex adelostoma, Carex diandra, Carex heleonastes, Glaux maritima, Hippuris tetraphylla, Juncus gerardii, Juncus squarrosus, Lychnis flos-cuculi, Ruppia maritima, Sagina caespitosa, Stellaria borealis, Vaccinium vitis-idaea, Veronica anagallis-aquatica; NT: Carex nardina, Crepis paludosa, Filaginella uliginosa, Hydrocotyle vulgaris, Listera ovata, Isoetes lacustris; LC: Callitriche hermaphroditica, Carex brunnescens, Carex livida, Carex pulicaris, Galium trifidum, Lathyrus palustris, Sanguisorba officinalis, Zannichellia palustris.

\subsubsection{Current peatland: location, extent, status, land use and greenhouse gas emissions}

\section{Material and Methods}

To assess the geospatial distribution and the extent of land use on organic soils, we used:

- the GIS raster dataset "Icelandic Geographical Land Use Database" (IGLUD 2014) with 21 land cover and land use types, in $15 \times 15$ m pixel size resolution and a reference scale of 1:30,000, delivered by the Faculty of Environmental Sciences of the Agricultural University of Iceland. The database contains map layers of diverse origin, geographically referable datasets from field work and geographical data related to surveys on specific map layers. The compilation of this dataset is described in Gudmundsson et al. (2013) and in the National Inventory Report of Iceland (NIS Iceland 2014). The IGLUD identifies "Cropland on organic soil" on the basis of ditch density (Gísladóttir et al. 2010), by assuming that all Cropland with a ditch density higher than $10 \mathrm{~km} / \mathrm{km}^{2}$ 
is on "organic soil.106. "Grassland on organic soil" is identified on the basis of a map layer "drained land" (NIS Iceland 2014).

- The Soil Map of Iceland (Jardvegskort af Islandi), a vector dataset with a reference scale of 1:500,000 and with a large portion of soil complexes containing both organic and mineral soils (Arnalds \& Óskarsson 2009).

- The National Inventory Submission for Iceland to the Climate Convention UNFCCC (NIS107 Iceland 2014). The NIS provides information on the distribution and use of drained "organic soils" as derived from the IGLUD database.

We extracted from IGLUD the categories "Cropland on organic soil," "Grassland on organic soil" (together accounting for almost all drained and used "organic soil" areas reported in NIS Iceland 2014), and "Wetland other". We renamed these categories according to Table 2.

Table 2: Land use categories extracted from the "Icelandic Geographical Land Use Database" (IGLUD 2014, see above) and their new names used in this study

\begin{tabular}{|c|c|c|c|}
\hline \multirow[t]{2}{*}{ New names used in this study } & \multicolumn{3}{|c|}{ Extracted IGLUD (2014) categories ${ }^{108}$} \\
\hline & $\begin{array}{l}\text { "Cropland on } \\
\text { organic soil" }\end{array}$ & $\begin{array}{l}\text { "Grassland on } \\
\text { organic soil" }\end{array}$ & $\begin{array}{c}\text { Wetlands } \\
\text { other }\end{array}$ \\
\hline $\begin{array}{l}\text { Cropland on "organic soil", drained } \\
\text { Grassland on "organic soil", drained }\end{array}$ & $\mathbf{x}$ & $\mathbf{x}$ & \\
\hline Wetland other, undrained & & & $\mathbf{x}$ \\
\hline
\end{tabular}

The Soil Map of Iceland was used to arrive at a rough indication of the distribution of the IGLUD land use categories "Cropland on organic soil" and "Grassland on organic soil" over the soil types Histosol and Histic Andosol, which are both organic soils according to FAO and IPCC definitions (Figure 4). The "organic soil" in the IGLUD dataset (cf. "Cropland on organic soil" and "Grassland on organic soil") contains a considerable amount of Gleyic Andosol, which is not an organic soil

106 The concept of "organic soil" as applied in Iceland includes Histosols, Histic Andosols and Gleyic Andosols of which the latter has an organic carbon content of $<12 \%$ (see Table 5 and NIS Iceland 2014). This conflicts with the definition of organic soil of FAO and IPCC.

107 The National Inventory Submission ('NIS') consists of the National Inventory Report ("NIR") and the Common Reporting Format ("CRF"). Since both the NIR and the CRF were used, we will refer further to the complete National Inventory Submission of Iceland (NIS Iceland 2014).

108 Geospatial data separating Forest Land and Reservoirs on organic soil from those on mineral soil are not available in the IGLUD database. Numerical area data for these categories were taken from the NIS Iceland (2014). 
according to FAO and IPCC definitions because of its low $(<12 \%)$ content of organic Carbon. To avoid confusion we write "organic soil" (with inverted commas) in case of the IGLUD concept, and without inverted commas when referring to the FAO/IPCC concept. The area of drained organic soils in the sense of FAO and IPCC (Histosols and Histic Andosols) could thus not be directly assessed with geospatial data.

Futher data on organic soil extent were derived from Arnalds (2008) and Guðmundsson \& Óskarsson (2008).109

For the area of drained organic soils as shown in Table 4 (only Histosols and Histic Andosols), the land use type "drained agriculture" was assumed. For emission calculation, we applied an average default emission factor of the Tier 1 emission factors for Cropland and Grassland for the Boreal climate/vegetation zone (after IPCC 2014).

Also the emissions from the drained "organic soils" (Histosols, Histic Andosols and Gleyic Andosols) as reported in NIS Iceland (2014, see Table 5) were recalculated using these new IPCC (2014) Tier 1 default factors (Table 3) as the NIS Iceland (2014) had used the IPCC (2006, Tier 1) default emission factors. The emission recalculation resulted in approximately 6 times higher annual emissions (see Table 5).

Table 3: Emission factors for $\mathrm{CO}_{2}$ as used in NIS Iceland (2014) and the IPCC (2014) Tier 1 emission factors as used for emission recalculation. Land use categories according to UNFCCC/IPCC

\begin{tabular}{lrr} 
IPCC category & Emission factors for $\mathrm{CO}_{\mathbf{2}}$ in $\mathbf{t} \mathrm{CO}_{2} / \mathbf{h a} / \mathbf{y r}$ \\
& NIS Iceland (2014) & IPCC (2014) \\
Forest Land & 0.6 & 2.2 \\
Cropland & 18.3 & 29.0 \\
Grassland (all other) & 0.9 & $20.9^{1)}$ \\
Cropland converted to Grassland & 9.6 & 2 2) \\
Grassland converted to Wetlands High SOC & 2.8 & \\
\hline
\end{tabular}

${ }^{1)}$ Deeply drained: average of EF "Grassland, drained, nutrient-poor" and "Grassland, deep-drained, nutrient-rich" (excl. EF "Grassland, shallow drained, nutrient-rich" from IPCC 2014).

${ }^{2)}$ EF from NIS Iceland (2014) used.

We did not include Carbon loss from DOC (Dissolved Organic Carbon). Peat carbon stock estimates were derived from the literature.

\footnotetext{
$109 \mathrm{http}$ ///landbunadur.is/landbunadur/wgrala.nsf/Attachment/LandUse_Jon_Gudmundsson/\$file/ LandUse_Jon_Gudmundsson.pdf
} 


\section{Results}

Organic soils mainly occur in the broad valleys of the West and the North of Iceland (Figure 3, Gudmundsson 1978). They are primarily found at low to moderate altitudes on the Tertiary basaltic plateau.

Figure 3: Distribution of Cropland, Grassland and Wetlands, undrained on soil types Histosol and Histic Andosol (on the basis of IGLUD 2014 and the Soil Map of Iceland; see Material and Methods)
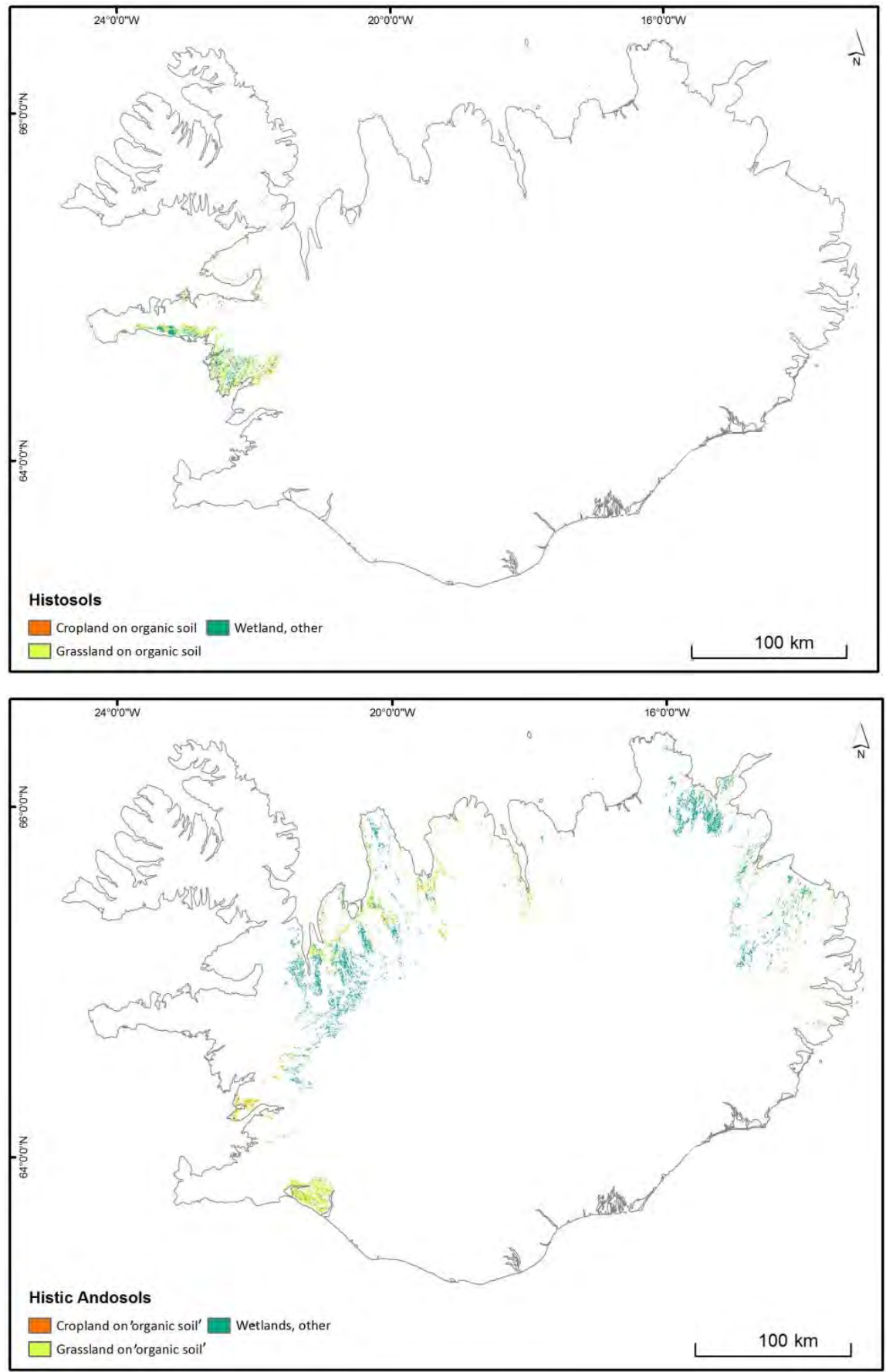
The total extent of organic soils (Histosols and Histic Andosols) in Iceland is reported to be $577.7 \times 10^{3}$ ha (Arnalds 2008, seeTable 4). After Guðmundsson \& Óskarsson (2008) ${ }^{110} 366.5 \times 10^{3}$ ha of these organic soils can be assumed drained, which leads to annual $\mathrm{CO}_{2}$ emissions of $7.7 \mathrm{Mt} \mathrm{CO}_{2}$ (Table 4).

Table 4: Area, drainage status and emissions of organic soils in Iceland (Histosols and Histic Andosols); total area of organic soil from Arnalds (2008, see Table 5); drained organic soil area after Guðmundsson \& Óskarsson (2008)

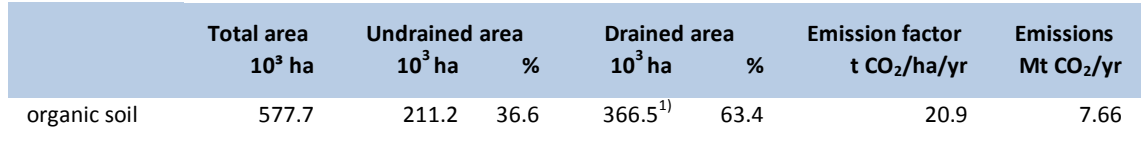

1) These areas are assumed to be predominantly agriculturally used and an average default emission factor derived from IPCC (2014) was applied (see above).

According to the National Inventory Submission (NIS Iceland 2014), $422.1 \times 10^{3}$ ha (50.4\%) of the "organic soils" (including Histosols, Histic Andosols and Gleyic Andosols; see Figure 4) in Iceland are directly or indirectly impacted by drainage and (few by) flooding, including $3.6 \mathrm{x}$ $10^{3}$ ha of Forest Land on drained "organic soil", $57.3 \times 10^{3}$ ha of Cropland on drained "organic soil", $361.1 \times 10^{3}$ ha of Grassland on drained "organic soil" and $0.1 \times 10^{3}$ ha of "organic soils" flooded by reservoirs (Grassland converted to Wetlands: High SOC; Table 6). These areas have, according to the NIS Iceland (2014), an annual $\mathrm{CO}_{2}$ emission of 1.5 Mt, but recalculation using the latest IPCC (2014) emission factors for $\mathrm{CO}_{2}$ would increase these emissions to $9.2 \mathrm{Mt}$ annually (Table 6). This difference is mainly due to the much higher emission factors for $\mathrm{CO}_{2}$ for all categories adopted by IPCC (2014; Table 3).

The soil organic carbon stored in organic soils (Histosols and Histic Andosols) was estimated by Oskarsson et al. (2004) to be $650 \mathrm{Mt}$. The ash content of the peat is usually high (10-35\%), owing to the frequent deposition of volcanic ash and to soil erosion. Due to drainage and degradation the peat carbon stock is continuously decreasing. Ongoing losses of SOC are estimated to be $50-100 \times 10^{3}$ t C per year (Óskarsson et al. 2004).

\section{Discussion}

As a result of high input of mineral material by erosion and deposition of volcanic ashes, only about $1 \%$ of the territory of Iceland classifies as

\footnotetext{
$110 \mathrm{http}$ ///landbunadur.is/landbunadur/wgrala.nsf/Attachment/LandUse_Jon_Gudmundsson/\$file/ LandUse_Jon_Gudmundsson.pdf
} 
Histosols (Icelandic: "mójörð”; peatland; Tinganelli 2013) which is surprisingly little considering the high latitude $\left(63-66^{\circ} \mathrm{N}\right)$ and the extent of wetlands (800-1,000 x 103 ha; Arnalds 2004). Arnalds (2008) argues that without the volcanic (andic) influences wetland soils in Iceland would be mostly Histosols.

Tab. 6: Drained "organic soil" areas, land use types and associated $\mathrm{CO}_{2}$ emissions. Left part of the table: as reported in the National Inventory Submission of Iceland (NIS 2014) to the UNFCCC. Right part: recalculation of emissions with the new IPCC (2014) default emission factors for $\mathrm{CO}_{2}$

\begin{tabular}{|c|c|c|c|c|c|c|c|c|c|}
\hline \multirow[t]{2}{*}{ ICELAND } & \multicolumn{4}{|c|}{ National Inventory Submission 2014} & \multirow[b]{2}{*}{$\begin{array}{l}\text { Uncer- } \\
\text { tainty }\end{array}$} & \multirow[b]{2}{*}{$\begin{array}{r}\text { Area } \\
\text { data \% }\end{array}$} & \multirow[b]{2}{*}{$\begin{array}{r}\text { Uncer- } \\
\text { tainty } \\
\text { EF \% }\end{array}$} & \multicolumn{2}{|c|}{$\begin{array}{l}\text { Recalculated according to } \\
\text { IPCC } 2014\end{array}$} \\
\hline & $\begin{array}{r}\text { Area of } \\
\text { "organic } \\
\text { soil" } \\
\left(10^{3} \mathrm{ha}\right)\end{array}$ & $\begin{array}{r}\text { Net carbon } \\
\text { stock change } \\
\text { per area } \\
(\mathrm{t} \mathrm{CO} / / \mathrm{ha} / \mathrm{yr})\end{array}$ & $\begin{array}{r}\text { Emissions } \\
(\mathrm{Mt} \mathrm{CO} / \mathrm{yr})\end{array}$ & $\begin{array}{r}\text { EF } \\
\text { TIER }\end{array}$ & & & & $\begin{array}{r}\text { Net carbon } \\
\text { stock change } \\
\text { per area } \\
(\mathrm{t} \mathrm{CO} / / \mathrm{ha} / \mathrm{yr})\end{array}$ & $\begin{array}{r}\text { Emissions } \\
(\mathrm{Mt} \mathrm{CO} / \mathrm{yr})\end{array}$ \\
\hline $\begin{array}{l}\text { Land Use Category } \\
\text { Forest Land remain- } \\
\text { ing Forest Land }\end{array}$ & & & & & & & & & \\
\hline $\begin{array}{l}\text { Afforestations older } \\
\text { than } 50 \text { years }\end{array}$ & 0.05 & 0.6 & 0.00 & 1 & & $x$ & $x$ & 2.2 & 0.00 \\
\hline $\begin{array}{l}\text { Natural Birch forest } \\
\text { older than } 50 \text { years }\end{array}$ & 0.50 & 0.6 & 0.00 & 1 & & & & 2.2 & 0.00 \\
\hline $\begin{array}{l}\text { Cropland converted } \\
\text { to Forest Land }\end{array}$ & & & & & & & & & \\
\hline $\begin{array}{l}\text { Afforestation 1-50 } \\
\text { years old }\end{array}$ & 0.30 & 0.6 & 0.00 & 1 & & $x$ & $x$ & 2.2 & 0.00 \\
\hline $\begin{array}{l}\text { Grassland converted } \\
\text { to Forest Land }\end{array}$ & & & & & & & & & \\
\hline $\begin{array}{l}\text { Afforestations 1-50 } \\
\text { years old -Cultivated } \\
\text { forest }\end{array}$ & 2.80 & 0.6 & 0.00 & 1 & & $x$ & $x$ & 2.2 & 0.01 \\
\hline$\sum$ FOREST LAND & 3.65 & & 0.00 & & & & & & 0.01 \\
\hline $\begin{array}{l}\text { Cropland remaining } \\
\text { Cropland }\end{array}$ & 54.50 & 18.3 & 1.00 & 1 & & 20 & 90 & 29.0 & 1.58 \\
\hline $\begin{array}{l}\text { Wetlands converted } \\
\text { to Cropland }\end{array}$ & 2.80 & 18.3 & 0.05 & 1 & & & & 29.0 & 0.08 \\
\hline$\Sigma C R O P L A N D$ & 57.30 & & 1.05 & & & & & & 1.66 \\
\hline $\begin{array}{l}\text { Grassland remaining } \\
\text { Grassland }\end{array}$ & & & & & & $20-30$ & 90 & & \\
\hline $\begin{array}{l}\text { Cropland abandoned } \\
\text { for more than } 20 \\
\text { years }\end{array}$ & 5.10 & 0.9 & 0.00 & 1 & & & & 20.9 & 0.11 \\
\hline $\begin{array}{l}\text { Natural birch shrub- } \\
\text { land - old }\end{array}$ & 0.20 & 0.9 & 0.00 & & & & & 20.9 & 0.00 \\
\hline
\end{tabular}




\begin{tabular}{|c|c|c|c|c|c|c|c|c|c|}
\hline \multirow[t]{2}{*}{ ICELAND } & \multicolumn{4}{|c|}{ National Inventory Submission 2014} & \multirow[b]{2}{*}{$\begin{array}{l}\text { Uncer- } \\
\text { tainty }\end{array}$} & \multirow[b]{2}{*}{$\begin{array}{r}\text { Area } \\
\text { data \% }\end{array}$} & \multirow[b]{2}{*}{$\begin{array}{c}\text { Uncer- } \\
\text { tainty } \\
\text { EF \% }\end{array}$} & \multicolumn{2}{|c|}{$\begin{array}{l}\text { Recalculated according to } \\
\text { IPCC } 2014\end{array}$} \\
\hline & $\begin{array}{r}\text { Area of } \\
\text { "organic } \\
\text { soil” } \\
\left(10^{3} \mathrm{ha}\right)\end{array}$ & $\begin{array}{r}\text { Net carbon } \\
\text { stock change } \\
\text { per area } \\
\left(\mathrm{t} \mathrm{CO}_{2} / \mathrm{ha} / \mathrm{yr}\right)\end{array}$ & $\begin{array}{l}\text { Emissions } \\
(\mathrm{Mt} \mathrm{CO} / \mathrm{yr})\end{array}$ & $\begin{array}{r}\text { EF } \\
\text { TIER }\end{array}$ & & & & $\begin{array}{r}\text { Net carbon } \\
\text { stock change } \\
\text { per area } \\
\left(\mathrm{t} \mathrm{CO}_{2} / \mathrm{ha} / \mathrm{yr}\right)\end{array}$ & $\begin{array}{r}\text { Emissions } \\
(\mathrm{Mt} \mathrm{CO} / \mathrm{yr})\end{array}$ \\
\hline $\begin{array}{l}\text { Wetlands drained for } \\
\text { more than } 20 \text { years }\end{array}$ & 314.70 & 0.9 & 0.29 & & & & & 20.9 & 6.58 \\
\hline $\begin{array}{l}\text { Cropland converted } \\
\text { to Grassland }\end{array}$ & 9.50 & 9.6 & 0.09 & & & & & 20.9 & 0.20 \\
\hline $\begin{array}{l}\text { Wetlands converted } \\
\text { to Grassland }\end{array}$ & 31.60 & 0.9 & 0.03 & & & & & 20.9 & 0.66 \\
\hline$\sum$ GRASSLAND & 361.10 & & 0.41 & & & & & & 7.55 \\
\hline \multicolumn{10}{|c|}{$\begin{array}{l}\text { Grassland converted to Wet- } \\
\text { lands }\end{array}$} \\
\hline High SOC ${ }^{1)}$ & 0.10 & 2.8 & 0.00 & 2 & & $20-30$ & 90 & 2.8 & 0.00 \\
\hline$\Sigma$ WETLANDS & 0.10 & & 0.00 & & & & & & \\
\hline$\Sigma$ TOTAL & $\begin{array}{r}422.1 \\
5\end{array}$ & & 1.47 & & & & & & 9.21 \\
\hline
\end{tabular}

1) "The high SOC soils are in most cases organic soils or peatlands or peat land previously converted to Grassland or Cropland through drainage." (NIS Iceland 2014).

${ }^{2)}$ The IPCC (2014) supplement does not provide new guidance on permanently flooded land like reservoirs.

Figure 4: The distribution of Cropland, Grassland and Wetlands, undrained on "organic soil" (Histosol, Histic Andosol and Gleyic Andosol) in Iceland (IGLUD 2014, see Material and Methods)

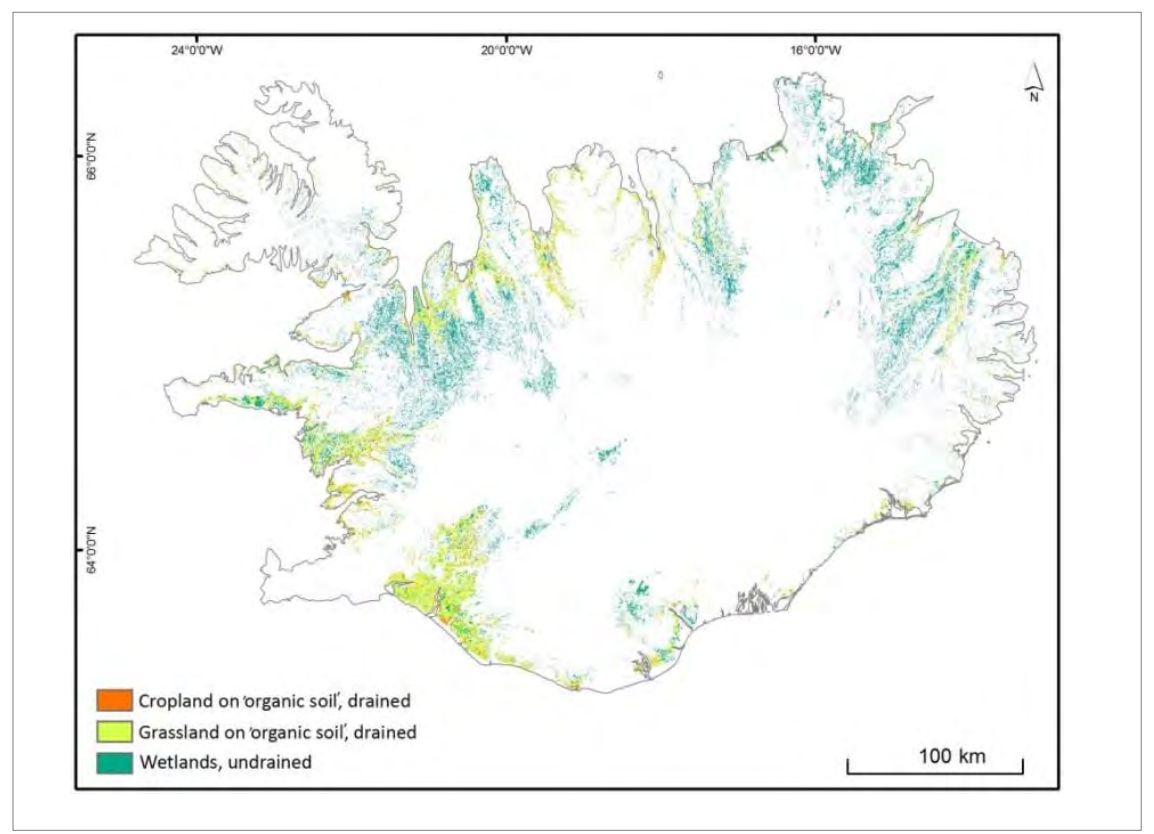


The IGLUD database and the NIS Iceland (2014) follow a concept of "organic soils" which conflicts with the conventions of FAO and IPCC, as next to Histosols and Histic Andosols also Gleyic Andosols are classified under "organic soils". Gleyic Andosols (with an organic Carbon content of $<12 \%$; Table 5), however, do not comply with the FAO and IPCC definitions of organic soil.111,112 This implies that in the IGLUD database and the NIS Iceland (2014), both the area of organic soil and the corresponding $\mathrm{CO}_{2}$ emissions from drained organic soils are probably overestimated.

Table 5: Total extent and main diagnostic criteria of Histosols, Histic Andosols and Gleyic Andosols in Iceland (after Arnalds 2008)

\begin{tabular}{lrr} 
Soil Type & Organic carbon content (\%) & Extent (10 \\
& & ha) \\
Histosol & $>20$ & 107.7 \\
Histic Andosol & $12-20$ & 470.0 \\
Gleyic Andosol & $<12$ & 260.0 \\
Total & & 837.7 \\
\hline
\end{tabular}

\subsubsection{Potentials for conservation and restoration}

Sloping mires e.g. in the western Fiords and the lowlands in the South have become very rare mire habitats and their restoration would promote the preservation of biodiversity in Iceland (Thórhallsdóttir 2000). However, between 1907 and 2010 ecological restoration of wetland habitats only accounted for $1 \%$ of the total restored area in the country (Table 7 ).

Table 7: Number and extent of ecological restoration areas in Iceland for wetlands, woodland and heathland/grassland (1907-2010; after Aradóttir et al. 2013)

\begin{tabular}{|c|c|c|c|c|c|c|}
\hline \multirow[t]{2}{*}{ Habiat type } & \multicolumn{4}{|c|}{ Number of areas in each size class $\left(10^{3} \mathrm{ha}\right)$} & \multicolumn{2}{|c|}{ Area per Habitat type } \\
\hline & $<0.1$ & $0.1-1$ & $1-10$ & $>10$ & $10^{3}$ ha & $\%$ of total area \\
\hline wetland & 18 & & 1 & & 2.6 & 1 \\
\hline woodland & 8 & 17 & 5 & & 19.2 & 11 \\
\hline heath-/grassland & 13 & 4 & 29 & 1 & 157.3 & 88 \\
\hline total & 39 & 21 & 35 & 1 & 179.1 & 100 \\
\hline
\end{tabular}

Iceland signed the Convention on Biological Diversity (CBD'113) in 1994, undertaking extensive obligations regarding conservation and sustainable use of nature's resources (Jóhannesdóttir 2013).

\footnotetext{
111 http://www.fao.org/docrep/x5872e/x5872e07.htm\#5.6\%20Classification\%20of\%200rganic\% 20Soils\%20According\%20to\%20Soil\%20Taxonomy)

$112 \mathrm{http}: / /$ www.ipcc.ch/meetings/session37/Doc_8b_Rev_2_Accepted_Report_Wetlands.pdf

113 http://www.cbd.int/
} 
The execution of the convention requires increased efforts in documenting and mapping of species and communities, their protective status and building of accessible databases. In 2008 the national biodiversity strategy for Iceland ${ }^{114}$ was accepted by the government, which includes the inventory of all undisturbed wetland areas. ${ }^{115}$

A comprehensive wetland inventory, which besides the remaining natural habitats also includes drained and degrading areas and their restoration potential, will facilitate balancing objectives of conservation and restoration of nature and biodiversity with economy (e.g. agriculture) and society (e.g. infrastructure, recreation). Currently, the restoration of wetlands to retain and restore their ecosystem services (e.g. as $\mathrm{CO}_{2}$ stores and sinks) is considered of national importance (Wald 2012) and contributes to the objectives of the UN Framework Convention on Climate Change. It is indeed thanks to the efforts of Iceland that the UNFCCC has in 2012 adopted the new activity "Wetland drainage and rewetting" to make rewetting of peatlands and organic soils accountable under the Kyoto Protocol for complying with national emission reduction commitments. Also the implementation of the biodiversity strategy may enhance the restoration of peatlands and wetlands with organic soils in Iceland.

Iceland is also Party to the Ramsar Convention on Wetlands and therefore it is important that land use conforms to goals of sustainable development.116 Conflicts between various land use types (e.g. residence, cultivation, industry) and biodiversity conservation and nature protection are mostly restricted to the lowlands of Iceland (Jóhannesdóttir 2013).

Currently, an interdisciplinary group from municipalities, farmers, universities, NGO's and government is developing an action plan/program for rewetting and restoration of drained wetlands. This includes developing institutional structure, methods for prioritizing and creating incentives for rewetting programs. Iceland has been at the front with other nations who advocate rewetting of drained wetlands as a method for reducing greenhouse gas emissions. This objective is highly prioritised in the group's" agenda, along with other factors like biological diversity and impact on other land use. The group is scheduled to present the action plan in 2015.

\footnotetext{
114 http://www.umhverfisraduneyti.is/media/PDF_skrar/liffjolbreytni.pdf

${ }^{115}$ Available at: http://www.umhverfisraduneyti.is/media/PDF_skrar/liffjolbreytni.pdf

116 http://www.ramsar.org/sites/default/files/documents/library/hbk4-01.pdf
} 


\subsubsection{Acknowledgements}

We thank Hlynur Óskarsson and Sigmundur H. Brink from the Agricultural University of Iceland for GIS data preparation and delivery and especially Hlynur Óskarsson for his essential review of the country chapter draft.

\subsubsection{References}

Aradóttir Á.L., Petursdottir T., Halldorsson G., Svavarsdottir K. \& Arnalds O. (2013). Drivers of Ecological Restoration: Lessons from a Century of Restoration in Iceland. Ecology and Society 18(4): 33. http://dx.doi.org/10.5751/ES-05946-180433

Arnalds O. (2004). Volcanic soils of Iceland. Catena 56: 3-20. http://dx.doi.org/10.1016/j.catena.2003.10.002

Arnalds Ó. (2008). Soils of Iceland. Jökull 58: 409-421.

Arnalds Ó. \& Óskarsson H. (2009). "Íslenskt Jarðvegskort." Náttúrufræðingurinn 78(34): 107-121.

Esri ArcGIS: World Imagery. Source: Esri. DigitalGlobe. GeoEye. i-cubed. USDA. USGS. AEX. Getmapping. Aerogrid. IGN. IGP. swisstopo. and the GIS User Community.

Gísladóttir F., Gudmundsson J.\& Áskelsdóttir S. (2010). Mapping and density analyses of drainage ditches in Iceland. In: Bryn A., Dramstad W. \& Fjellstad W. (eds.), Mapping and monitoring of Nordic Vegetation and landscapes. Hveragerði, Norsk Insitute for Skog og Landskap 1/2010, pp. 43-46. Available at: http://www.skogoglandskap.no/filearchive/viten_01_10_mapping_and_monitorin g_of_nordic_vegetation_and_landscapes.pdf.

Gudmundsson T. (1978). Pedological studies of Icelandic peat soils. PhD thesis. University of Aberdeen.

Guðmundsson J. \& Óskarsson H. (2008). Other carbon storages to be included under carbon reservoir mechanism? 3rd Informal Dialog on the role of land use land use changes and forestry in the climate change responce. 7th-9th of May, Agricultural University of Iceland, Reykjavík. Available at: http://landbunadur.is/landbunadur/ wgrala.nsf/Attachment/LandUse_Jon_Gudmundsson/\$file/

LandUse_Jon_Gudmundsson.pdf

Guðmundsson J. \& Óskarsson, H. (2014). Carbon dioxide emission from drained organic soils in West-Iceland. Soil carbon sequestration for climate food security and ecosystem services, Reykjavík Iceland, JRC science and policy report, pp. 155-159.

Guðmundsson J., Gísladóttir F. Ó., Brink S.H. \& Óskarsson H. (2010). The Icelandic Geographic Land Use Database (IGLUD). In: Bryn A., Dramstad W. \& Fjellstad W. (eds.), Mapping and monitoring of Nordic vegetation and landscapes, 1, Ås, Norway. http://skogoglandskap.pdc.no/index.php?t=V\&seks_id=21176

Gudmundsson J., Brink S.H. \& Gísladóttir, F. (2013). Preparation of a LULUCF land-use map for Iceland: Development of the Grassland layer and subcategories Grassland Science in Europe 13.

Institute of Economic Studies (2004). Wetlands in Iceland. Research Report 04/01, Reykjavík.

IPCC (2006). 2006 IPCC Guidelines for National Greenhouse Gas Inventories, Prepared by the National Greenhouse Gas Inventories Programme, Eggleston H.S., Buendia L., Miwa K., Ngara T. \& Tanabe K. (eds.), published by IGES, Japan. 
IPCC (2014). 2013 Supplement to the 2006 IPCC Guidelines for National Greenhouse Gas Inventories: Wetlands. Hiraishi T., Krug T., Tanabe K., Srivastava N., Baasansuren J., Fukuda M. \& Troxler T.G. (eds), Published by IPCC. Switzerland.

IGLUD (2014). Icelandic Geographical Land Use Database. Agricultural University of Iceland (eds: Gudmundsson J., Brink S.H.)

NIS Iceland (2014). Wöll C.B.S., Hallsdóttir J., Guðmundsson A., Snorrason J., Pórsson P. V. K., Jónsson K., Andrésson K. \& Einarsson S. (2014). Emissions of greenhouse gases in Iceland from 1990 to 2012. National Inventory Report 2014; Submitted under the United Nations Framework Convention on Climate Change and the Kyoto Protocol, 270 p. + Annexes.

Óskarsson H., Arnalds Ó., Gudmundsson J. \& Gudbergsson G. (2004). Organic carbon in Icelandic Andosols: geographical variation and impact of erosion. Catena 56: 225-238. http://dx.doi.org/10.1016/j.catena.2003.10.013

Oskarsson H. (2013). The value of peatland rewetting for reducing GHG emission. Nordic seminar of peatland drainage and environment. November 4-6. Kuopio (Finland). Available at: http://www.oulu.fi/sites/default/files/ Kuopio_Oskarsson_2013_pienennetty.pdf.

Tinganelli L. (2013). Assessment of spatial and temporal changes in Histosol distribution in wetland areas in the Mosfell Valley. BS thesis, Life and Environmental Sciences University of Iceland, $48 \mathrm{p}$.

Thorhallsdottir T.E. (2000). Icelandic mires, unpublished manuscript.

Thorhallsdottir T.E., Oskarsson H. \& Magnússon B. (2015). Iceland. In: Joosten H., Tanneberger F. \& Moen A. (eds.), Mires and peatlands of Europe: Status, distribution, and nature conservation. Schweizerbart Science Publishers, Stuttgart.

Wald E.C. (2012). Land-use Development in South Iceland 1900-2010, Master thesis, Faculty of Biology and Environmental Science, University of Iceland, pp. 95.

Walker D. A., Raynolds M.K., Daniëls F.J.A., Einarsson E., Elvebakk A., Gould W.A., Katenin A.E., Kholod S.S., Markon C.J., Melnikov E.S., Moskalenko N.G., Talbot S.S., Yurtsev B.A.(†) \& the other members of the CAVM Team (2005). The Circumpolar Arctic vegetation map. Journal of Vegetation Science 16: 267-282. Available at: http://www.geobotany.uaf.edu/library/pubs/WalkerDA2005_jvs_16_267.pdf, http://dx.doi.org/10.1111/j.1654-1103.2005.tb02365.x 


\subsection{Denmark}

\subsubsection{Characterization of the country}

Figure 1: NorBalWet countries covered in this report (grey); Denmark (dark grey)

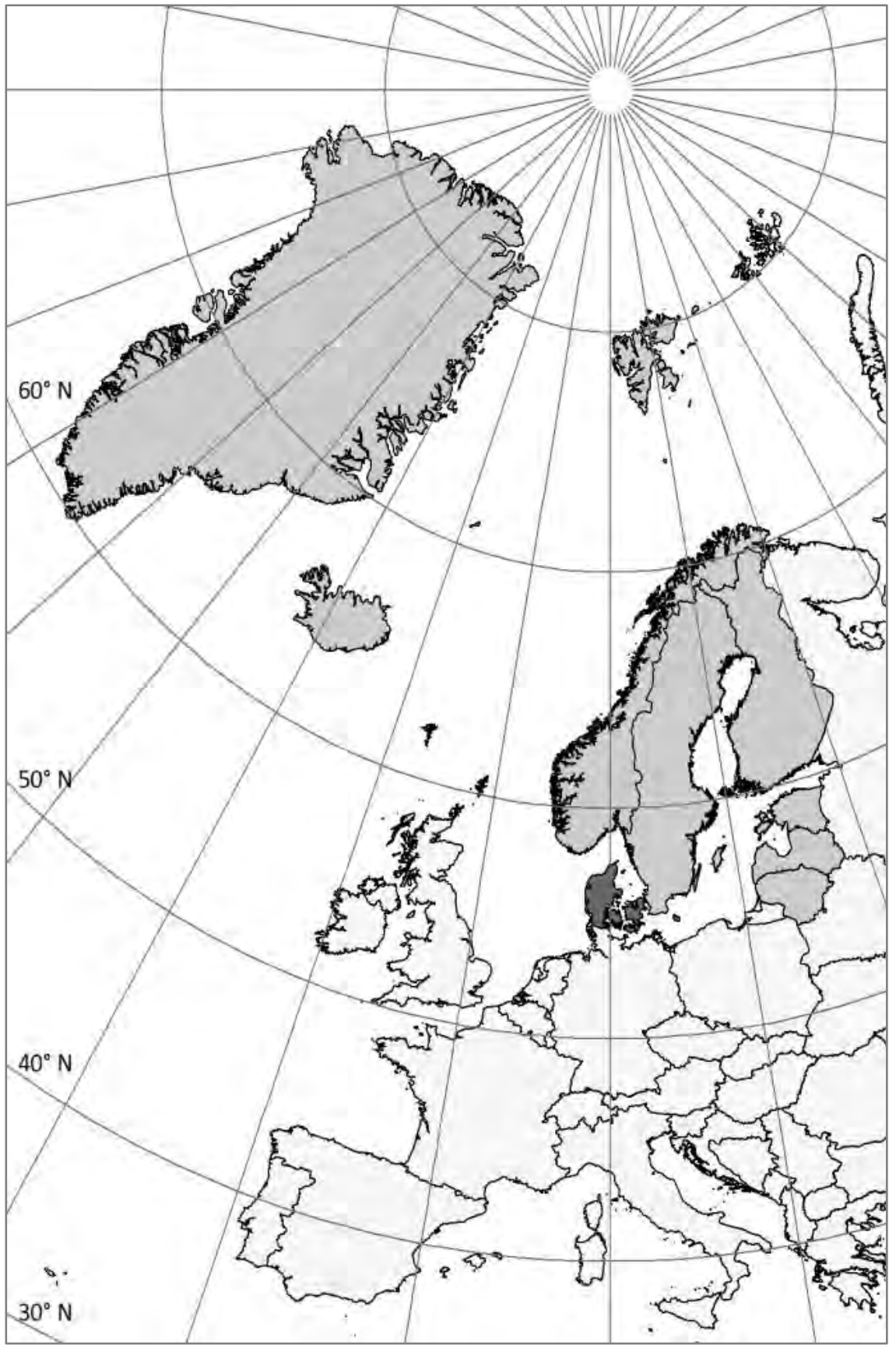


Denmark (Figure 1) consists of the Peninsula Jutland (Jylland), the large Islands Zealand (Sjælland) and Funen (Fyn) and hundreds of smaller Islands. The country stretches between $57^{\circ} 45^{\prime}-54^{\circ} 34^{\prime} \mathrm{N}$ and $8^{\circ} 5^{\prime}-15^{\circ} 12^{\prime}$ E (Figure 1). The only country border on land is towards Germany in the South. The highest elevation is $171 \mathrm{~m}$ a.s.l. (Risager et al. 2015).

Due to the influence of the North Atlantic Drift, Golfstrømmen, the climate of Denmark is rather warm. The average annual temperature ranges from $7.4{ }^{\circ} \mathrm{C}$ in central Jutland to $8.4{ }^{\circ} \mathrm{C}$ in some coastal areas. The mean summer temperature is $15.2^{\circ} \mathrm{C}$ and the mean winter temperature $0.5^{\circ} \mathrm{C}$. Average annual precipitation is $712 \mathrm{~mm}$, but precipitation varies significantly across the country and between years (Risager et al. 2015).

Eastern Denmark's hilly landscape is dominated by Weichselian calcareous till deposits. Western Jutland was not glaciated during this last glaciation and has gently undulating Saalian till "Islands" surrounded by extensive, acid Weichselian sander plains (Risager et al. 2015).

\subsubsection{Peatland diversity}

According to Dau (1829) the German concept "Moor" equals the "tørvemose" in Danish and refers to any place with a natural deposit of peat (Risager et al. 2015). The term "mose" includes marsh, wet forests, and wet meadows including spring areas with no or only little peat accumulation (Risager et al. 2015). At present "mose" basically refers to natural or low intensity used areas with freshwater wetland vegetation, also when these areas are (partly) drained (Risager et al. 2015).

Based on the water regime, a distinction is made between solely rain fed raised bogs (højmoser) and fens (kær) with geogenous water supply (Risager et al. 2015). The term "højmose" was already used by Dalgas (1876) for areas with peat formation above the groundwater level, and the term "lavmose" for peat formation below the groundwater level (synonymous with "kær"). The typology of "kær" follows the Swedish tradition after du Rietz (1949) and includes extremely poor fen (ekstremfattigkær), transitional poor fen (overgangsfattigkær), transitional rich fen (overgangsrigkær), and extremely rich fen (ekstremrigkær). This classification is based on the presence of characteristic and differential plant species and follows a pH gradient (cf. Risager et al. 2015). 
Meadows (eng) developed due to grazing and mowing from fen (kær). Low intensity used and species rich habitats were called "eng", whereas drained, fertilised and ploughed areas with introduced grasses are cultural meadows (kultur-eng). "Strandeng" refers to saline meadows and marsh with vegetation adapted to high water tables and high salinity, which may be peat forming (Risager et al. 2015).

\subsubsection{Peatland degradation}

The peatlands of Denmark have been used since prehistoric times. Some small scale peat-pits $(\varnothing 1.5-3 \mathrm{~m})$ date to the Bronze Age and larger peatpits $(\varnothing>100 \mathrm{~m})$ to the Pre Roman Iron Age. Danish bog bodies mainly date to the Iron Age (Risager et al. 2015). Around 1800, Denmark covered $17 \%$ of its primary energy consumption with peat. Peat consumption increased from $110 \mathrm{~kg}$ per capita/year in the early 19th century to about 250-300 kg per capita/year in the period 1830 to 1850 . After 1870 a rapid replacement of peat by coal started with the establishment of railroads in the rural areas (Henriques \& Sharp 2014). Peat extraction has caused a considerable reduction of the mire area up to the early 1950s. In 1980-2013 peat extraction was mainly for horticulture and the extracted volume varied between 145,000 and $399,000 \mathrm{~m}^{3}$ annually (Risager et al. 2015).

The peatlands of Denmark have also been in agricultural use for centuries. Peat was regularly used to fertilize fields. Large efforts between 1940 and 1970 aimed to bring more land under farming and were financially supported by the Danish government. This led to the straightening of rivers and streams and the drainage of wetlands, lakes and shallow fjords. In the 1970s, eutrophication of surface waters, loss of biodiversity and problems with ochre led to a stop of new drainage (Klöve et al. 2009). Currently, the prevailing agricultural uses of peatlands are grazing, mowing and intensive crop cultivation (Risager et al. 2015).

Approximately $10 \%$ of the red-listed species in the Danish Red Data Book have their occurrence in freshwater habitats. Particularly vulnerable groups include vascular plant, moss and invertebrate species of alkaline springs and fens and invertebrate species of bogs and transition mires. The overall conservation status reported for "moist to wet terrestrial habitat types of Denmark" (i.e. wet heaths, meadows, tall herb fringe communities, raised and quaking bogs, fens, peat filled depressions, springs) was in 2013 reported to the EU as "unfavourable" to "bad". Out of 188 mire areas, where formerly red-listed plant species occurred, only 57 localities remain (Ejrnæs 2009). 


\subsubsection{Current peatland: location, extent, status, land use and greenhouse gas emissions}

\section{Material and Methods}

To assess the location and extent of peatlands and the type of land use applied, we used two separate peatland datasets.

\section{Dataset 1:}

- Contains the data of the national inventory of " $\$ 3$ nature" according to the 2009 Nature Protection Act (AA 2009a). We extracted the category "mose", which represent areas with peat occurrence, and the categories "eng" and "strandeng", which includes areas with and without peat. In the text we refer to these categories as "peatlands" (between inverted commas) because of the inclusion of non-peatland areas.

Dataset 1 only includes what has been mapped as $\S 3$ areas, which should indicate some quality of nature. In principle no tilled areas should be included, but there may be exceptions. §3 Strandeng may include areas with peat, in former times Eng was defined as grazed mire, almost always initiated by some drainage. Before $1992 \S 3$ Mose was only mapped if there was peat. Since 1992 the category is based on vegetation. The drainage status of $\S 3$ is unknown. The content of peat in Strandeng and Eng cannot be accessed from $\S 3$. For Mose, based on experience, the majority is drained and situated in a heavily fragmented landscape. Per definition all Mose should be peatland, but with long time drainage this might no longer apply for all sites.

\section{Dataset 2:}

- Contains the combined dataset for A) agriculturally used organic soils (Greve et al. 2014) and B) Natura 2000 registration of the peatland habitat types 7110 (Active raised bogs), 7120 (Degraded raised bogs still capable of natural regeneration) and 7140 (Transition mires and quaking fens). This dataset was delivered by Mogens H. Greve (senior scientist at the Department of Agroecology at Aarhus University) and further referred to as "organic soils").

Dataset 2 might underestimate the extent of organic soils due to the exclusion of several Natura 2000 habitat types that are related to peatland, e.g. habitat types 7210 (Calcareous fens with Cladium mariscus and plant species of the community Caricion davallianae), 7220 (Petrifying 
springs with tufa formation and plant species of the community Cratoneurion) and 7230 (Alkaline fens).

Dataset 1 and Dataset 2 partly overlap. In several areas they complement one another, as is illustrated by the artificial borders of the units they use (land use type, nature protection status or subsidy data). Combining both datasets - to receive a more complete coverage would, according to the originators of the data, result in an overestimation of the peatland area. We therefore analysed both datasets separately. For error analysis, we underlay both GIS datasets with satellite images of Google Earth, OpenCycleMap OCM (http://www.opencyclemap.org/) and the World Imagery layer (Esri ArcGIS). This analysis showed that Dataset 2 underestimate the area of drained organic soils as can, for example, be concluded from the fragmented coverage of continuous drained lowland.

To tackle the shortcomings of Datasets 1 and 2, we additionally considered the land use area data on drained organic soils from:

- the recent National Inventory Submission of Denmark to the United Nations Framework Convention on Climate Change (UNFCCC; NIS117 Denmark 2014).

The NIS Denmark (2014) provides information on the distribution and use of drained organic soils for Forest Land based on the National Forest Inventory (NFI). The NFI is a continuous sample-based inventory with partial replacement of sample plots using a $2 \times 2 \mathrm{~km}$ grid covering entire Denmark. At each grid intersection, a cluster of four circular plots (with a radius of $15 \mathrm{~m}$ ) are placed in a $200 \times 200 \mathrm{~m}$ grid. About one third of the plots are permanent and re-measured every five years. Two thirds are temporary and moved randomly within the particular $2 \times 2 \mathrm{~km}$ grid cell in subsequent inventories. On each plot the presence and state of ditches and drainage conditions are recorded. Furthermore, the presence of peatland is recorded and the depth of the peat is measured (NIS Denmark 2014).

117 The National Inventory Submission ("NIS") consists of the National Inventory Report ("NIR") and the Common Reporting Format ("CRF"). Since the NIR and the CRF were used, it will be referred below to the complete National Inventory Submission of Denmark as NIS Denmark (2014). 
For Cropland and Grassland, a complete new soil map of organic soils was made in 2010, which is a statistical map based on $>10,000$ soil samples down to the mineral soil, combined with a digital elevation map (DEM) with a resolution of $1.6 \mathrm{~m}$ covering entire Denmark, water table maps and old maps with organic soils. For the NIS Denmark (2014) this organic soil map has been overlaid by a map on which $99 \%$ of all Danish farmed fields ( $>636,000$ fields) that receive EU subsidies are mapped with $<0.5$ meter uncertainty (NIS Denmark 2014). Although these data precisely assess the area of different crop- and grassland types, the result probably underestimates the real extent of drained organic soils (as, for example, fallows are excluded).

To assess land use on organic soils, we furthermore used:

- the BASEMAP land-use and land-cover map for Denmark (Jepsen \& Levin 2013).

We aggregated the 36 land use units of this dataset into 10 new land use types and assigned the probable drainage status to these types (Table 1), including the status "shallowly drained" to the land use type "bog" (based on own observations) except for the southern part of Lille Vildmose, which was assigned the status "undrained". 118

Overlay analysis with the Datasets 1 and 2 showed that the land use of $7.7 \times 10^{3}$ ha of the "peatland" area in Dataset 1 and $1.1 \times 10^{3}$ ha of the "organic soil" area of Dataset 2 is undefined in the BASEMAP (cf. Levin et al. 2012).

\begin{tabular}{|c|c|c|c|c|c|c|c|}
\hline \multicolumn{2}{|c|}{ BASEMAP } & \multicolumn{2}{|c|}{ This study } & \multicolumn{2}{|c|}{ BASEMAP (continued) } & \multicolumn{2}{|c|}{ This study (continued) } \\
\hline $\begin{array}{l}\text { object } \\
\text { number }\end{array}$ & object name & $\begin{array}{l}\text { aggregate land } \\
\text { use type }\end{array}$ & $\begin{array}{l}\text { drainage } \\
\text { status }\end{array}$ & $\begin{array}{r}\text { object } \\
\text { number }\end{array}$ & object name & $\begin{array}{l}\text { aggregate land } \\
\text { use type }\end{array}$ & $\begin{array}{l}\text { drainage } \\
\text { status }\end{array}$ \\
\hline 0 & undefined & undefined & unknown & 18 & cemetary & Infrastructure & drained \\
\hline 1 & building & infrastructure & drained & 19 & resource extraction & peat extraction & \\
\hline 2 & track & infrastructure & drained & 20 & stream & water & unknown \\
\hline
\end{tabular}

\footnotetext{
118 The extent of the southern part of Lille Vildmose was assessed manually in GIS and subtracted from the total area of land use type "other drained (shallowly)."

${ }^{119}$ Aggregation reduces the land use types to a reasonable minimum for this study. Since emission factors stratified for e.g. different kinds of grassland are not available, it is not reasonable to show all land use subtypes separately in the map or to calculate emissions separately.

${ }^{120}$ All original land use units of Jepsen \& Levin (2013) are included in the GIS overlay analysis, since e.g roads or buildings can also be built on peatland.
} 


\begin{tabular}{|c|c|c|c|c|c|c|c|}
\hline \multicolumn{2}{|c|}{ BASEMAP } & \multicolumn{2}{|c|}{ This study } & \multicolumn{2}{|c|}{ BASEMAP (continued) } & \multicolumn{2}{|c|}{ This study (continued) } \\
\hline $\begin{array}{l}\text { object } \\
\text { number }\end{array}$ & object name & $\begin{array}{l}\text { aggregate land } \\
\text { use type }\end{array}$ & $\begin{array}{l}\text { drainage } \\
\text { status }\end{array}$ & $\begin{array}{r}\text { object } \\
\text { number }\end{array}$ & object name & $\begin{array}{l}\text { aggregate land } \\
\text { use type }\end{array}$ & $\begin{array}{l}\text { drainage } \\
\text { status }\end{array}$ \\
\hline 3 & tank track & infrastructure & drained & 21 & sea & & \\
\hline 4 & fire line & infrastructure & drained & 22 & forest & forested & drained \\
\hline 5 & road & infrastructure & drained & 23 & rock & rock & undrained \\
\hline 6 & rail & infrastructure & drained & 24 & wetland & water & unknown \\
\hline 7 & runway & infrastructure & drained & 25 & coast & coast & \\
\hline 8 & city-centre & infrastructure & drained & 26 & agric. undef. & agriculture & drained \\
\hline 9 & high buildings & infrastructure & drained & 27 & agric. intens. & & \\
\hline 10 & low buildings & infrastructure & drained & 28 & agric. extens. & & \\
\hline 11 & industry & infrastructure & drained & 29 & lake & water & unknown \\
\hline 12 & parking & infrastructure & drained & 30 & dune sand & coast & \\
\hline 13 & technical area & infrastructure & drained & 31 & heathland & heathland & \\
\hline 14 & harbour & infrastructure & drained & 32 & dry grassland & grassland & drained \\
\hline 15 & basin & infrastructure & drained & 33 & bog & other & \\
\hline 16 & recreation & infrastructure & drained & 34 & coastal meadow & grassland & \\
\hline 17 & sport facility & infrastructure & drained & 35 & wet-meadow & & \\
\hline
\end{tabular}

Table 2 shows the overlay analysis of the "peatland" and "organic soil" GIS Datasets 1 and 2 with the aggregated land use data of Jepsen \& Levin (2013).

Table 2: Land use types on organic soils resulting from overlay analysis of the "peatland" and "organic soils" GIS Datasets 1 and $2^{121}$ with the aggregated land use types based on Jepsen \& Levin (2013; Table 1). Only land use types are shown that are relevant for emission calculation

\begin{tabular}{|c|c|c|c|c|c|c|c|c|c|c|}
\hline \multirow[t]{2}{*}{$\begin{array}{l}\text { Land use types distin- } \\
\text { guished in our GIS study }\end{array}$} & & eatla & Ad"/"Organic & soil" & \multicolumn{6}{|c|}{$\begin{array}{c}\text { Land use type } \\
\text { (Jepsen \& Levin 2013) }\end{array}$} \\
\hline & mose & eng & strandeng & $\begin{array}{r}\text { organic } \\
\text { soil }\end{array}$ & $\begin{array}{l}\text { Heath- } \\
\text { land }\end{array}$ & forest & $\begin{array}{l}\text { agri- } \\
\text { culture }\end{array}$ & $\begin{array}{l}\text { grass- } \\
\text { land }\end{array}$ & $\begin{array}{r}\text { Peat } \\
\text { extraction }\end{array}$ & other $^{1}$ ) \\
\hline drained forested & $x$ & $x$ & $x$ & $x$ & & $x$ & & & & \\
\hline drained agriculture (deeply) & $x$ & $x$ & $x$ & $x$ & & & $x$ & & & \\
\hline drained grassland (deeply) & $x$ & $x$ & $x$ & $x$ & & & & $x$ & & \\
\hline drained peat extraction & $x$ & $x$ & $x$ & $x$ & & & & & $x$ & \\
\hline drained other (shallowly)1) & $x$ & $x$ & $x$ & $x$ & & & & & & $x$ \\
\hline
\end{tabular}

1) Land use unit "bog" from Jepsen \& Levin (2013) is considered to be shallowly drained (own observations), except the southern, undrained part of the peatland "Lille Vildmose", which was manually assessed in GIS, subtracted from total area of "drained other (shallowly)" and renamed "undrained other".

121 Contains the combined dataset for A) agriculturally used organic soils (Greve et al. 2014) and B) Natura 2000 registration of peat associated habitat types (types $7120,7110,7140$ ). 
Underlaying the land use GIS dataset (Jepsen \& Levin 2013) with satellite images of Google Earth, OpenCycleMap OCM (http://www.open cyclemap.org/) and the World Imagery layer (Esri ArcGIS) showed that the dataset represents various land use units in Denmark mostly very precisely and in high resolution. However, uncertainties in the "peatland" dataset used for the overlay analysis with this land use data probably cause uncommon land use types as "drained forested" areas in "peatland" type Strandeng (see Table 6).

Emissions were calculated using the IPCC (2014) default emission factors for $\mathrm{CO}_{2}$ for the Temperate climate/vegetation zone (Table 3). For land use types "drained agriculture (deeply)" and "drained grassland (deeply)" emission factors were derived using the IPCC (2014) default emission factors. For land use type "drained other (shallowly)" an appropriate emission factor was applied (see Table 3).

\begin{tabular}{|c|c|c|}
\hline Land use type & $\begin{array}{r}\text { Emission factor (EF) } \\
t \mathrm{CO}_{2} / \mathrm{ha} / \mathrm{yr}\end{array}$ & Emission factor (EF) comments \\
\hline $\begin{array}{l}\text { drained agriculture } \\
\text { (deeply) }\end{array}$ & 23.5 & $\begin{array}{l}\text { average of all IPCC } 2014 \text { tier } 1 \text { default EFs for Cropland and Grassland } \\
\text { excl. EF "Grassland, shallow drained, nutrient-rich" }\end{array}$ \\
\hline $\begin{array}{l}\text { drained grassland } \\
\text { (deeply) }\end{array}$ & 20.9 & $\begin{array}{l}\text { average of IPCC } 2014 \text { tier } 1 \text { default EFs "Grassland, drained, nutrient- } \\
\text { poor" and "Grassland, deep-drained, nutrient- rich" (excl. EF "Grassland, } \\
\text { shallow drained, nutrient-rich") }\end{array}$ \\
\hline drained forested & 9.5 & IPCC 2014 tier 1 default EF "Forest Land, drained" \\
\hline drained peat extraction & 10.3 & IPCC 2014 tier 1 default EF "Peatland Managed for Extraction" \\
\hline drained other (shallowly) & 13.3 & IPCC 2014 tier 1 default EF "Grassland, shallow drained, nutrient-rich" \\
\hline
\end{tabular}

Table 4 shows the Tier 2 emission factors as applied in NIS Denmark (2014). The Tier 2 emission factors of NIS Denmark (2014) are considerably higher for Cropland and Peat extraction and considerably lower for Forest Land and Grassland. In effect both approaches result in almost similar $\mathrm{CO}_{2}$ emissions (Table 8). 
Table 4: Emission factors for $\mathrm{CO}_{2}$ as used in NIS Denmark (2014) and the IPCC (2014) Tier 1 default emission factors used for emission recalculation. Land use categories according to UNFCCC/IPCC

\begin{tabular}{lcr} 
IPCC category & Emission factors for $\mathrm{CO}_{2}$ in $\mathbf{~} \mathrm{CO}_{2} / \mathbf{h a} / \mathbf{y r}$ & \\
& NIS Denmark (2014) & IPCC (2014) \\
Forest Land & 1.2 & 9.5 \\
Cropland & 38.9 & 29.0 \\
Grassland & 4.6 & $20.9^{1)}$ \\
Peat extraction & 21.7 & 10.3 \\
\hline
\end{tabular}

1) Deeply drained: average of EFs "Grassland, drained, nutrient-poor" and "Grassland, deep-drained, nutrient-rich" (excl. EF "Grassland, shallow drained, nutrient-rich" from IPCC 2014).

To address the utilization pressure and threat of peatland types and mire habitats in Denmark, we used:

- the "Notat til By og Landsskabsstyrelsen med udkast til Kapitel 1 til 4 landerapporten til CBD om tilstand, udvikling og trusler for Danmarks Biodiversitet (Draft for $\mathrm{CBD}^{122}$ on conditions, development and threats for the biodiversity of Denmark;" Ejrnæs 2009123).

Carbon loss from DOC (Dissolved Organic Carbon) is not included in this study.

Peat carbon stocks were derived from Djurhuus et al. (2005).

\section{Results}

\section{Dataset 1}

According to the GIS overlay analysis (Table 2), Mose covers $96.6 \times 10^{3}$ ha (Figure 2), of which $6.4 \times 10^{3}$ ha (6.6\%) is undrained (Figure 3) and $82.9 \times$ $10^{3}$ ha $(85.9 \%)$ is drained and used for forestry, agriculture or peat extraction. Associated annual emissions amount to $1.14 \mathrm{Mt} \mathrm{CO}_{2}$ (Table 5, 6). Mose with unknown drainage conditions cover $7.3 \times 10^{3}$ ha $(7.5 \%)$.

Eng covers $96.0 \times 10^{3}$ ha (Figure 2), of which $0.2 \times 10^{3}$ ha $(0.2 \%)$ is undrained (Figure 3) and $89.9 \times 10^{3}$ ha $(93.6 \%)$ is drained and used for forestry, agriculture or peat extraction. Associated annual emissions amount to $1.87 \mathrm{Mt} \mathrm{CO}_{2}$ (Table 5,6). Eng areas with unknown drainage conditions cover $6.0 \times 10^{3}$ ha $(6.2 \%)$.

Strandeng includes a significant area of non-peatland (see Chapter 4.1.) and has been thus excluded from the total "peatland" area and from

\footnotetext{
122 Convention on Biological Diversity (http://www.cbd.int/).

${ }^{123}$ Available at: http://pure.au.dk//portal/files/17886698/4.LanderapportBiodiv_notat.pdf
} 
the calculation of emissions from drained "peatland". Results of our GIS overlay analysis are, however, shown for strandeng (Table 5, 6).

\begin{tabular}{|c|c|c|c|c|c|c|c|c|}
\hline \multirow[t]{2}{*}{$\begin{array}{l}\text { "Peatland" } \\
\text { type }\end{array}$} & \multirow{2}{*}{$\begin{array}{l}\text { Area } \\
10^{3} \mathrm{ha}\end{array}$} & \multicolumn{2}{|c|}{ Undrained Area } & \multicolumn{2}{|c|}{ Drained Area } & \multicolumn{2}{|c|}{$\begin{array}{l}\text { Area with unknown } \\
\text { drainage }\end{array}$} & \multirow{2}{*}{$\begin{array}{l}\text { Emissions } \\
\mathrm{Mt} \mathrm{CO}_{2} / \mathrm{yr}\end{array}$} \\
\hline & & $10^{3} \mathrm{ha}$ & $\%$ & $10^{3}$ ha & $\%$ & $10^{3}$ ha & $\%$ & \\
\hline \multicolumn{9}{|l|}{ DATASET 1} \\
\hline Mose & 96.6 & 5.1 & 5.3 & 82.9 & 85.9 & 8.6 & 8.9 & 1.14 \\
\hline Eng & 96.0 & 0.0 & 0.0 & 89.9 & 93.6 & 6.2 & 6.4 & 1.87 \\
\hline$\sum$ total & 192.6 & 5.1 & 2.6 & 172.8 & 89.7 & 14.7 & 7.6 & 3.01 \\
\hline Strandeng ${ }^{1)}$ & 44.2 & 0.1 & 0.2 & 40.5 & 91.5 & 3.6 & 8.2 & 0.84 \\
\hline \multicolumn{9}{|l|}{ DATASET 2} \\
\hline $\begin{array}{l}\text { Peatland/ } \\
\text { organic soil }\end{array}$ & 109.1 & 5.1 & 4.7 & 90.2 & 82.7 & 13.8 & 12.6 & 1.90 \\
\hline
\end{tabular}

${ }^{1)}$ Strandeng includes a significant area of non-peatland (see Chapter 4.1.) and has been thus excluded from the assessment of drained "peatland" and related emissions.

According to the GIS overlay analysis (Table 2), "organic soils" cover $109.1 \times 10^{3}$ ha of Denmark, of which $90.2 \times 10^{3}$ ha $(82.7 \%)$ is drained (Figure 3) and used for forestry, agriculture or peat extraction. Associated annual emissions amount to $1.9 \mathrm{Mt} \mathrm{CO}_{2}$ (Table 7).

Table 6: Soil $\mathrm{CO}_{2}$ emissions for various types of land use on Mose, Eng and Strandeng in Denmark (Dataset 1; see Material and Methods above) using IPCC 2014 tier 1 default emission factors for $\mathrm{CO}_{2}$ for the Temperate climate/vegetation zone. Land use types do not correspond to UNFCCC/IPCC land use categories

\begin{tabular}{|c|c|c|c|}
\hline Peatland type and land use type & $\begin{array}{r}\text { Area } \\
\left(10^{3} \mathrm{ha}\right)\end{array}$ & $\begin{array}{l}\text { Emission factor } \\
\qquad\left(\mathrm{t} \mathrm{CO}_{2} / \mathrm{ha} / \mathrm{yr} \text { ) }\right.\end{array}$ & $\begin{array}{r}\text { Emissions } \\
\text { (Mt CO } / \mathrm{yr} \text { ) }\end{array}$ \\
\hline \multicolumn{4}{|l|}{ Mose } \\
\hline drained other (shallowly)1) & 75.1 & 13.3 & 1.00 \\
\hline undrained other 2) & 5.1 & \pm 0 & \pm 0 \\
\hline drained agriculture (deeply) & 1.7 & 23.5 & 0.04 \\
\hline drained grassland & 3.7 & 20.9 & 0.08 \\
\hline drained forested & 2.5 & 9.5 & 0.02 \\
\hline drained peat extraction & 0.0 & 10.3 & 0.00 \\
\hline heathland & 1.3 & & \\
\hline infrastructure & 2.1 & & \\
\hline undefined & 0.1 & & \\
\hline water & 5.0 & & \\
\hline coast & 0.0 & & \\
\hline$\sum$ subtotal & 96.6 & & 1.14 \\
\hline \multicolumn{4}{|l|}{ Eng } \\
\hline drained other (shallowly) $)^{1)}$ & 1.3 & 13.3 & 0.02 \\
\hline drained agriculture (deeply) & 3.9 & 23.5 & 0.09 \\
\hline drained grassland & 84.1 & 20.9 & 1.76 \\
\hline drained forested & 0.6 & 9.5 & 0.01 \\
\hline drained peat extraction & 0.0 & 10.3 & 0.00 \\
\hline heathland & 0.2 & & \\
\hline infrastructure & 1.9 & & \\
\hline undefined & 0.2 & & \\
\hline water & 3.9 & & \\
\hline
\end{tabular}




\begin{tabular}{|c|c|c|c|}
\hline Peatland type and land use type & $\begin{array}{r}\text { Area } \\
\left(10^{3} \mathrm{ha}\right)\end{array}$ & $\begin{array}{l}\text { Emission factor } \\
\qquad\left(\mathrm{t} \mathrm{CO}_{2} / \mathrm{ha} / \mathrm{yr}\right)\end{array}$ & $\begin{array}{r}\text { Emissions } \\
\text { (Mt CO//yr) }\end{array}$ \\
\hline coast & 0.0 & & \\
\hline$\sum$ subtotal & 96.0 & & 1.87 \\
\hline$\sum$ total & 192.6 & & 3.01 \\
\hline \multicolumn{4}{|l|}{ Strandeng ${ }^{3)}$} \\
\hline drained other (shallowly) ${ }^{1)}$ & 0.2 & 13.3 & 0.00 \\
\hline drained agriculture (deeply) & 0.2 & 23.5 & 0.01 \\
\hline drained grassland & 39.8 & 20.9 & 0.83 \\
\hline drained forested $^{4}$ & 0.2 & 9.5 & 0.00 \\
\hline drained peat extraction & 0.0 & 10.3 & 0.00 \\
\hline heathland & 0.1 & & \\
\hline infrastructure & 1.2 & & \\
\hline undefined & 0.1 & & \\
\hline water & 1.8 & & \\
\hline coast & 0.5 & & \\
\hline$\sum$ subtotal & 44.2 & & 0.84 \\
\hline
\end{tabular}

1) Land use unit "bog" in land use dataset from Jepsen \& Levin (2013). Excluded is the southern part of Lille Vildmose. For details see Material and Methods above.

2) Undrained, southern part of Lille Vildmose (area manually assessed in GIS).

${ }^{3)}$ Strandeng includes a significant area of non-peatland (see Material and Methods above) and has been thus excluded from the assessment of drained "peatland" and related emissions.

4) This land use type on peatland probably derives from uncertainties in the "peatland" dataset (see Material and Methods above), since it is unknown to exist in Denmark.

\section{Dataset 2}

Table 7: Extent of agriculturally used "organic soils" in Denmark (Dataset 2; see Material and Methods above) and associated soil $\mathrm{CO}_{2}$ emissions for various land use types (Tier 1 default emission factors from IPCC 2014 for $\mathrm{CO}_{2}$ and the Temperate climate/vegetation zone). Land use types do not correspond to UNFCCC/IPCC land use categories

\begin{tabular}{|c|c|c|c|}
\hline land use types on organic soil & $\begin{array}{r}\text { Area } \\
\left(10^{3} \mathrm{ha}\right)\end{array}$ & $\begin{array}{l}\text { Emissionfactor } \\
\text { (t CO } \mathrm{CO}_{2} / \mathrm{ha} / \mathrm{yr} \text { ) }\end{array}$ & $\begin{array}{r}\text { Emissions } \\
(\mathrm{Mt} \mathrm{CO} / \mathrm{yr})\end{array}$ \\
\hline drained other (shallowly) ${ }^{1)}$ & 17.9 & 13.3 & 0.31 \\
\hline undrained other ${ }^{2)}$ & 5.1 & \pm 0 & \pm 0 \\
\hline drained agriculture (deeply) & 44.3 & 23.5 & 1.04 \\
\hline drained grassland (deeply) & 25.1 & 20.9 & 0.52 \\
\hline drained forested & 3.0 & 9.5 & 0.03 \\
\hline drained peat extraction & 0.0 & 10.3 & 0.00 \\
\hline heathland & 0.3 & ? & \\
\hline infrastructure & 2.8 & & \\
\hline Undefined & 1.1 & & \\
\hline Water & 9.5 & & \\
\hline Coast & 0.0 & & \\
\hline$\sum$ Total & 109.1 & & 1.90 \\
\hline
\end{tabular}

1) Land use unit "bog" in land use dataset from Jepsen \& Levin (2013). Excluded is the southern part of Lille Vildmose. For details see Material and Methods above.

${ }^{2)}$ Undrained, southern part of Lille Vildmose (area manually assessed in GIS). 
Figure 2: Distribution of Mose, Eng and Strandeng across Denmark (unchanged "peatland" Dataset 1, see Material and Methods above). Map details: Store Vildmose area - a century ago the largest peatland in Denmark originally about 6,700 ha. Dataset 1 includes an unknown extent of non-peatland areas (especially in Strandeng; see Material and Methods above)

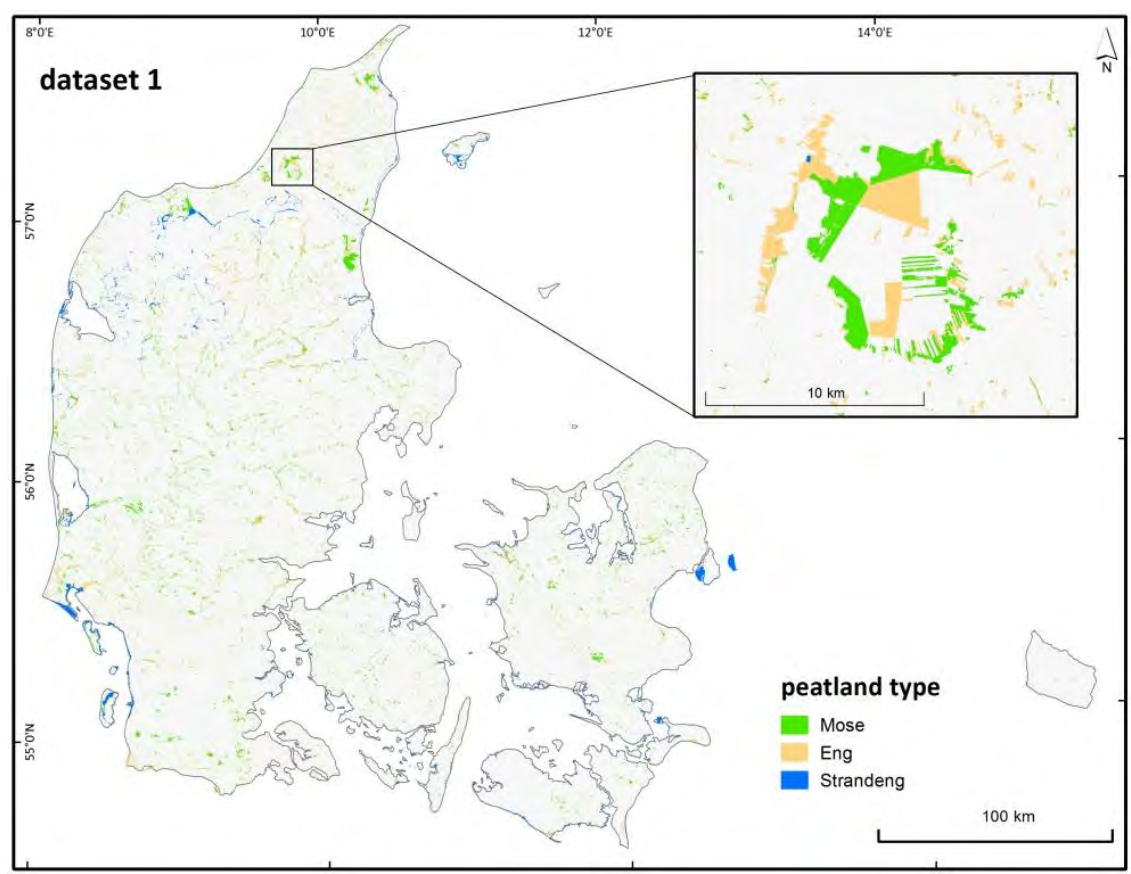


Figure 3: Location, extent and drainage status of "peatlands" and "organic soils" in Denmark resulting from the GIS overlay analysis of Dataset 1 and Dataset 2 with the land use dataset of Jepsen \& Levin (2013; see Table 2, Material and Methods above). Map details: Store Vildmose area. Dataset 1 includes an unknown extent of non-peatland areas (especially in Strandeng; see Material and Methods above)
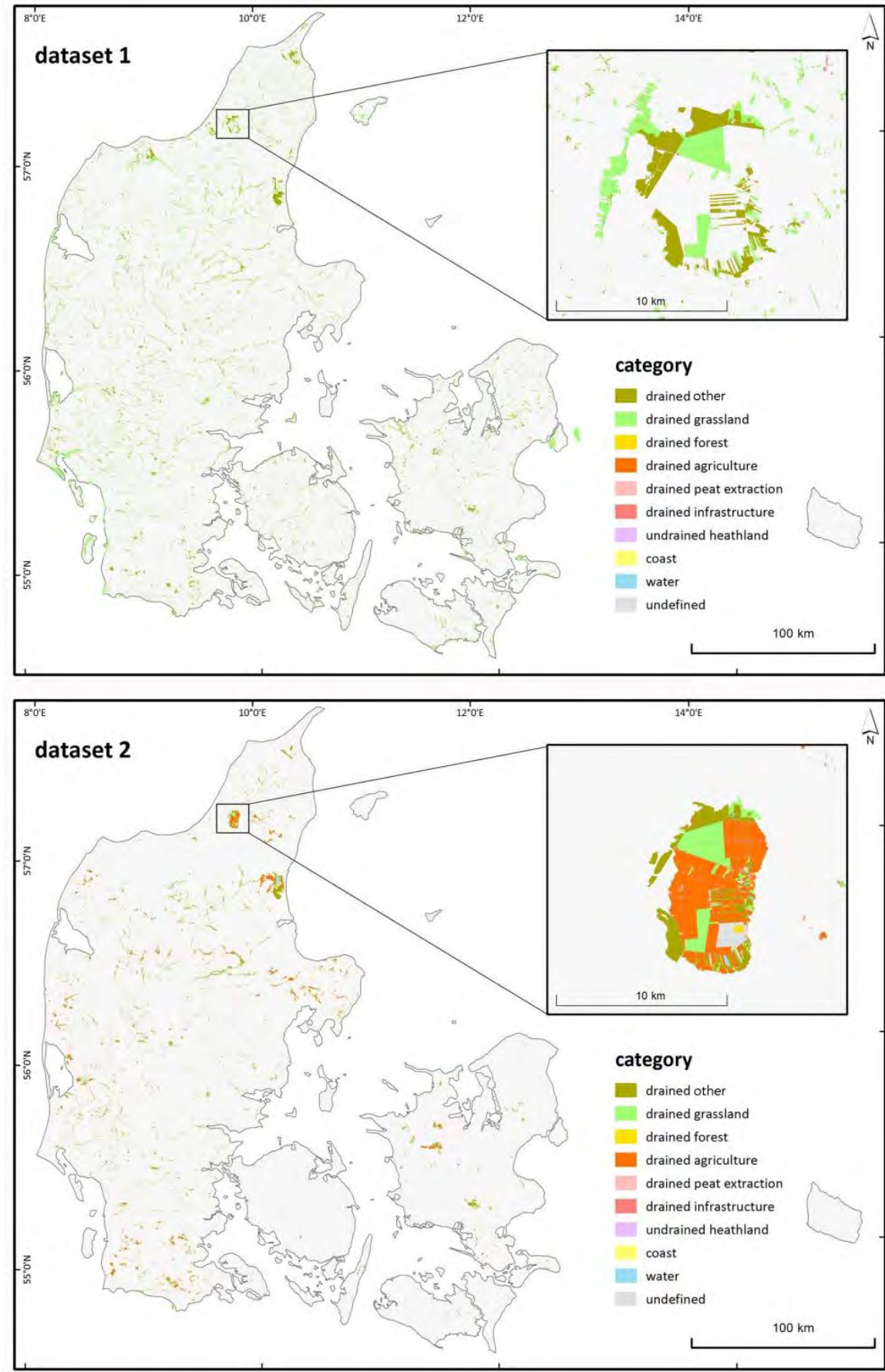
The National Inventory Submission (2014) reported $36.6 \times 10^{3}$ ha of Forest Land on drained organic soil, $50.9 \times 10^{3}$ ha Cropland on drained organic soil, $17.2 \times 10^{3}$ ha of Grassland on drained organic soil, and $1.6 \times$ $10^{3}$ ha of organic soil drained for Peat extraction (Table 8; NIS Denmark 2014). Drainage and use of these areas lead, according to the NIS Denmark, to an annual $\mathrm{CO}_{2}$ emission of $2.1 \mathrm{Mt}$. A similar sum results from application of the latest IPCC (2014) tier 1 default values for the Temperate climate/vegetation zone, although considerable differences in emission factors exist for all land use categories (Table 4, 8).

According to our analysis, only $0.2 \%$ of the Eng and Strandeng habitats remain undrained (Table 5) and undrained fens constitute the most threatened peatland habitats in Denmark. Furthermore, more than $95 \%$ of the active raised bogs have disappeared following centuries of exploitation (Risager et al. 2015). According to our overlay analysis of Dataset $1,82.9 \%$ of the current mose area is drained.

According to Djurhuus et al. (2005) the peat carbon stock of the uppermost one meter of "mires" (probably meaning peatlands ${ }^{124}$ ) in Denmark was reduced by about 40\% between 1930 and 1956 due to cutting of peat for fuel and currently amounts to 54.6 billion tons. The major reason for the drastic reduction is that Denmark is quite flat with often shallow organic layers. During recent years more and more previously organic soils do no longer comply with the depth criterion for organic soil. The area of organic soil will decrease rapidly in future because of ongoing oxidation (NIS Denmark 2014).

\section{Discussion}

In a country like Denmark with centuries of very intensive land use, it is difficult to assess the original mire area (before human influence). According to a variety of old data, mires may once have covered $20-25 \%$ of Denmark (Risager et al. 2015). The only near nationwide survey of peatlands was carried out from 1919 to 1940, covering most areas larger than 5 ha with a peat layer of more than $30 \mathrm{~cm}$. According to this survey, peatlands suitable for peat extraction covered $130.8 \times 10^{3}$ ha, but the total extent of peatlands was considerably larger (Risager et al. 2015). Estimates for the current area of peatlands in Denmark range from 91.0

124 In Scandinavia the term "myr" often has a pure vegetational connotation. In international publications the Nordic term "myr" is often translated into the English "mire", without considering that internationally the term "mire" refers to landscapes with a peat soil. This probably also applies to Djurhuus et al. (2005). 
x $10^{3}$ (Djurhuus et al. 2005) to $440.0 \times 10^{3}$ ha of "deep organic soils" 125 (Klöve et al. 2009; Table 9).

Table 8: Drained organic soil areas, land use types and associated $\mathrm{CO}_{2}$ emissions. Left part of the table: as reported in the National Inventory Submission of Denmark (NIS Denmark 2014) to the UNFCCC. Right part: recalculation of emissions with the new IPCC (2014) tier 1 default values

\begin{tabular}{|c|c|c|c|c|c|c|c|c|c|}
\hline \multirow[t]{2}{*}{ Denmark } & \multicolumn{4}{|c|}{ National Inventory Submission 2014} & \multirow[b]{2}{*}{$\begin{array}{l}\text { Uncer- } \\
\text { tainty }\end{array}$} & \multirow[b]{2}{*}{$\begin{array}{r}\text { Activity } \\
\text { data \% }\end{array}$} & & \multicolumn{2}{|c|}{$\begin{array}{l}\text { Recalculated according to IPCC } \\
2014\end{array}$} \\
\hline & $\begin{array}{r}\text { Area of } \\
\text { organic soil } \\
\left(10^{3} \text { ha }\right)\end{array}$ & $\begin{array}{r}\text { Net carbon } \\
\text { stock change } \\
\text { per area } \\
\left(\mathrm{t} \mathrm{CO}_{2} / \mathrm{ha} / \mathrm{yr}\right)\end{array}$ & $\begin{array}{r}\text { Emissions } \\
(\mathrm{Mt} \mathrm{CO} 2 / \mathrm{yr})\end{array}$ & $\begin{array}{r}\text { EF } \\
\text { TIER }\end{array}$ & & & $\begin{array}{r}\text { Uncer- } \\
\text { tainty } \\
\text { EF \% }\end{array}$ & $\begin{array}{r}\text { Net carbon } \\
\text { stock change } \\
\text { per area } \\
\left(\mathrm{t} \mathrm{CO}_{2} / \mathrm{ha} / \mathrm{yr}\right)\end{array}$ & $\begin{array}{r}\text { Emissions } \\
(\mathrm{Mt} \mathrm{CO} / \mathrm{yr})\end{array}$ \\
\hline Cropland converted to Forest Land & 5.3 & 1.2 & 0.01 & & & & & 9.5 & 0.05 \\
\hline Grassland converted to Forest Land & 5.0 & 1.2 & 0.01 & & & & & 9.5 & 0.05 \\
\hline$\sum$ FOREST LAND & 36.6 & & 0.05 & & & & & & \\
\hline $\begin{array}{l}\text { Cropland remaining Cropland } \\
\text { Forest Land converted to Cropland }\end{array}$ & $\begin{array}{r}50.9 \\
2)\end{array}$ & 38.9 & 1.98 & 2 & 10 & 10 & 90 & 29.0 & 1.48 \\
\hline $\begin{array}{l}\sum \text { CROPLAND } \\
\text { Grassland remaining Grassland }\end{array}$ & 50.9 & & 1.98 & & & & & & 1.48 \\
\hline $\begin{array}{l}\sum \text { GRASSLAND } \\
\text { Wetlands remaining Wetlands }\end{array}$ & 17.2 & & 0.08 & & & & & & 0.36 \\
\hline$\Sigma$ PEAT EXTRACTION & 1.6 & 21.7 & 0.03 & 2 & $x$ & $x$ & $x$ & 10.3 & 0.02 \\
\hline$\Sigma$ TOTAL & 106.3 & & 2.14 & & & & & & 2,202 \\
\hline
\end{tabular}

1) Tier level for "Forest Land"; no division into subcategories (NIS Denmark 2014).

${ }^{2)}$ Included in Cropland remaining Cropland (NIS Denmark 2014).

${ }^{3)}$ Included in Grassland remaining Grassland (NIS Denmark 2014).

Table 9: Area of wetlands, peatlands and organic soils in Denmark (according to different sources). Land use types only fully correspond to the UNFCCC/IPCC land use categories with respect to data from NIS Denmark (2014)

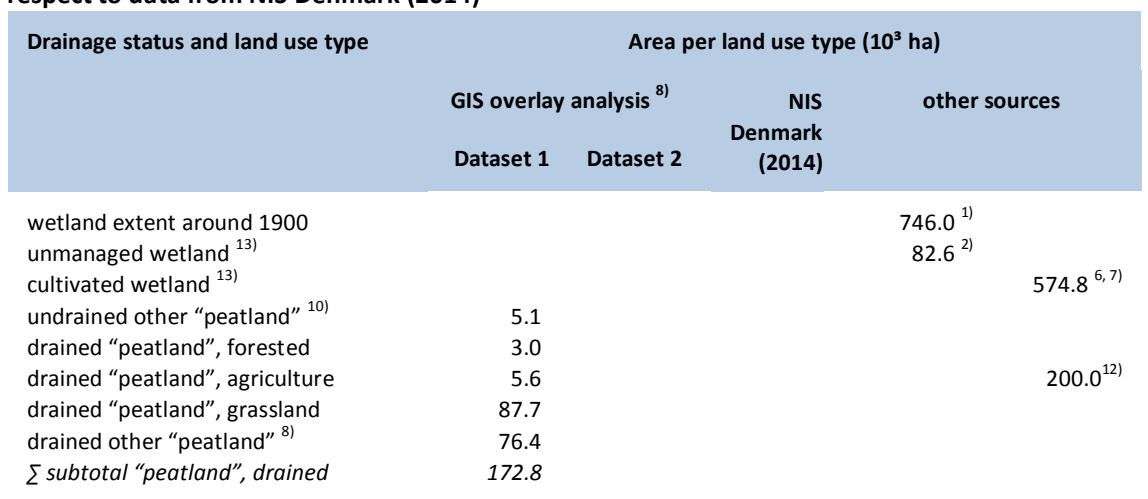

125 Including deep peat and gyttja. "The actual area may be less due to organic matter degradation converting some organic soils into mineral soils" (Klöve et al. 2009). 


\begin{tabular}{|c|c|c|c|c|c|}
\hline \multirow[t]{3}{*}{ Drainage status and land use type } & \multicolumn{5}{|c|}{ Area per land use type $\left(10^{3}\right.$ ha) } \\
\hline & \multicolumn{2}{|c|}{ GIS overlay analysis ${ }^{8)}$} & \multirow{2}{*}{$\begin{array}{r}\text { NIS } \\
\text { Denmark } \\
(2014)\end{array}$} & \multicolumn{2}{|c|}{ other sources } \\
\hline & Dataset 1 & Dataset 2 & & & \\
\hline$\sum$ total "peatland"11) & 192.6 & & & & \\
\hline drained organic soil, Forest Land & & 3.0 & 36.6 & & \\
\hline drained organic soil, Cropland & & & $50.9^{5)}$ & $118.0^{4)}$ & $92.73^{9)}$ \\
\hline drained organic soil, Grassland & & 25.1 & $17.2^{5)}$ & $60.0^{4)}$ & $5.56^{9)}$ \\
\hline drained organic soil, Peat extract. & & & 1.6 & $0.8-0.9^{3)}$ & \\
\hline undrained organic soil total ${ }^{10)}$ & & 5.4 & & & \\
\hline drained organic soil, agriculture & & 44.3 & & $200.0^{3)}$ & \\
\hline drained, other organic soil & & 17.9 & & & \\
\hline$\sum$ subtotal organic soil, drained & & 90.2 & 106.3 & $201.0^{3)}$ & $175.9^{6)}$ \\
\hline$\sum$ subtotal organic soil unclear drainage & & 13.8 & & & \\
\hline$\sum$ total organic soil & & $109.1^{11)}$ & & $440.0^{3)}$ & \\
\hline
\end{tabular}

${ }^{1)}$ Extent of low-lying soils (Hoffmann \& Baattrup-Pedersen 2007).

2) $56.9 \times 10^{3}$ ha of freshwater wetlands and $25.7 \times 10^{3}$ ha of salt marches (Hoffmann \& BaattrupPedersen 2007)

${ }^{3)}$ Includes deep peat and gyttja; actual extent may be less (Klöve et al. 2009).

${ }^{4)}$ According to the Danish soil classification carried out in 1975; > 12\% C in soil (NIS Denmark 2014).

5) "The definition of an organic soil (...) is $>20 \%$ organic matter with a peat depth of minimum 30 cm." (NIS Denmark 2014).

${ }^{6)}$ According to Bou Kheir et al. (2010). This study covers wetlands of Denmark that have been intensively cultivated since ancient times, and predicts and maps the geographic distribution of SOC across Denmark using remote sensing (RS), geographic information systems (GISs) and decision-tree modelling (un-pruned and pruned classification trees). Overall accuracy of these maps (compared with field observations) is estimated to approximately $70 \%$.

7) Two thirds of the area are cultivated mineral soils.

${ }^{8)}$ Land use type "bog" in land use dataset from Jepsen \& Levin (2013; see Material and Methods above).

${ }^{9)}$ Data from FAOStat, available at: http://faostat.fao.org/site/739/default.aspx\#ancor.

${ }^{10)}$ Covers the undrained, southern part of Lille Vildmose (land use type "undrained other") and land use type "undrained heathland" (see Material and Methods above, Table 6, 7)

${ }^{11)}$ Also include areas of unknown drainage (see Table 1, 6 and 7).

${ }^{12)}$ According to Klöve et al. (2009). Include deep peat and gyttja. "The actual area may be less due to organic matter degradation converting some organic soils into mineral soils".

13) "The area has been selected based on land use indicated in historical maps and on soil internal drainage" (Bou Kheir et al. 2010).

Area estimates for drained and used organic soils or peatlands in Denmark reach from $106.3 \times 10^{3}$ ha (NIS Denmark 2014), and $175.9 \times 10^{3}$ ha (Bou Kheir et al. 2010), to approximately $200.0 \times 10^{3}$ ha (Klöve et al. 2009,126 Table 9). Bou Kheir et al. (2010) estimated cultivated wetlands,

126 Including deep peat and gyttja; actual extent may be less (Klöve et al. 2009). 
both mineral and organic, totally occupying $574.8 \times 10^{3}$ ha. 127 Our GIS overlay analysis (Table 2) arrived at estimates of $93.3 \times 10^{3}$ ha for agriculturally used "peatlands "and additionally $76.4 \times 10^{3}$ ha of drained other "peatland"128 in Dataset 1 , and $69.4 \times 10^{3}$ ha of "organic soils" in Dataset 2, respectively (Table 9). However, both datasets seem to be biased by their input data (see Material and Methods above). To assess the total drained area, it might be reasonable to map all ditches and apply a drainage impact zone of $200 \mathrm{~m}$ (cf. NIS Iceland 2014).

The assessment of drained organic soils in NIS Denmark (2014) largely excludes the $\S 3$ "peatland" areas (pers comm. Steen Gyldenkærne; for information on $\S 3$ see Material and Methods above - Dataset 1) as they were assumed to be largely undrained, although quantitative data are lacking. A very large proportion of the Danish $\S 3$ "peatland" areas are in this study regarded as drained, and thus emitting $\mathrm{CO}_{2}$. Here we bring an indication of the implication of drainage, aware that this will be an overestimate of emission, and expect reality to be somewhat lower. We use for the drained peatland area a combination of the area of drained organic soil from NIS Denmark and the area of drained "Mose" from our GIS analysis of Dataset 1 (see Table 2, Chapter 4.1). We exclude $\S 3$ type Eng, as this is at least partially covered by NIS Denmark (2014), and $\S 3$ type Strandeng, as it includes non-peatland sites. The combined area of drained organic soil/"peatland" arrives at $189.2 \times 10^{3}$ ha (Table 10) with annual emissions of $3.3 \mathrm{Mt} \mathrm{CO}_{2}$. The total organic soil/"peatland" area in Denmark would be $202.9 \times 10^{3}$ ha, which additionally includes the undrained, southern part of Lille Vildmose with $5.1 \times 10^{3}$ ha and $8.6 \times 10^{3}$ ha "peatland" with unknown drainage (Dataset 1 ; Table 10). We conclude that NIS Denmark (2014) seems to underestimate the area of drained organic soils and related GHG emissions by approximately $1.2 \mathrm{Mt} \mathrm{CO}_{2}$.

The classification of the $\S 3$ peatland type Mose as predominantly drained (Table 6, 10129) may overestimate the related emissions to some extent, but a very large part of these areas is drained. This underpins a need for a mapping of the soil (organic or mineral) and of the drainage status in $\S 3$ peatland types.

\footnotetext{
127 The soil maps used were compiled in 1975, while the geological information (peat and gyttja) was gathered over a longer period (1880-2008). The extent of cultivated organic soils ranges from 172.3 to $180.0 \mathrm{x}$ $10^{3}$ ha depending on different model parameters.

${ }^{128}$ Land use type "bog" in land use dataset from Jepsen \& Levin (2013; see Material and Methods above). 129 This is related to the classification of the land use type "bog" of Jepsen \& Levin (2013) as drained (see Table 1).
} 
Table 10: Total and drained area of organic soils/"peatlands", land use types and associated $\mathrm{CO}_{2}$ emissions as a combination of NIS Denmark (2014) and the §3 “peatland" type Mose (Dataset 1). For details of emission calculation see Table 6,8

\begin{tabular}{|c|c|c|}
\hline Land use type & $\begin{array}{l}\text { Drained organic soil/“peatland” } \\
\qquad\left(10^{3} \mathrm{ha}\right)\end{array}$ & $\begin{array}{r}\text { Emissions } \\
(\mathrm{Mt} \mathrm{CO} / \mathrm{yr})\end{array}$ \\
\hline $\begin{array}{l}\sum \text { NIS Denmark (2014) drained organic soil } \\
\S 3 \text { "peatland" type Mose }\end{array}$ & 106.3 & 2.14 \\
\hline$\sum$ drained $^{1)}$ & 82.9 & 1.14 \\
\hline undrained $^{2)}$ & 5.1 & \pm 0 \\
\hline area with unknown drainage & 8.6 & ? \\
\hline$\sum$ drained & 189.2 & 3.34 \\
\hline$\sum$ total & 202.9 & \\
\hline
\end{tabular}

1) See Material and Methods above.

2) Land use type "undrained other" (southern undrained part of Lille Vildmose; (see Material and Methods above and Table 7).

\subsubsection{Peatland conservation and restoration efforts and the Ramsar site Lille Vildmose}

In 2013 Denmark designated Lille Vildmose (predominantly peatland) as its first Ramsar site (and the first site in the history of the convention) using criterion $1 \mathrm{vi}$, which relates this designation to the role of peatlands as carbon sinks, and thereby flagging their important role in climate regulation which an Nordic Baltic awareness project is planned to address in 2015. Lille Vildmose contains nationally important carbon stocks (approximately 10\%). Large degraded areas are rewetted as part of a major EU LIFE project, which is expected to lead to a substantial $\mathrm{CO}_{2}$ emission reduction as a result of the project implementation (see section 4.2.3). Lille Vildmose was also Ramsar designated based on biodiversity criteria, i.e. for protecting threatened ecological communities.

Denmark has at this point in time no specific plans to designate other peatland Ramsar sites. Potential candidates would be Store Vildmose and Store Åmose, the originally largest peatlands in Jutland and on Zeeland respectively. The Danish word "store" means big. Denmark updated the Ramsar site Information Sheets (RIS ${ }^{130}$ ) for its 27 other existing Ramsar sites in 2012, where assessments were undertaken considering each of the nine Ramsar criteria. These other Danish Ramsar sites are coastal and were originally designated because of large concentrations of waterbirds.

130 http://www.ramsar.org/sites/default/files/documents/pdf/cop11/res/cop11-res08-e-anx1.pdf; https://rsis.ramsar.org/about 
It is estimated that Denmark has lost at least $90 \%$ of its original mire area over the last two centuries, and also a very large proportion of its peatlands. Bogs, marshes and meadows in near natural conditions in Denmark are now protected from e.g. cultivation. Restoration projects have been implemented at several NATURA 2000 designated bogs, cofunded by EU LIFE. Restoration measures include optimization of hydrological regimes, clearing of trees and scrubs and introduction of Sphagnum fragments in, amongst others, Lille Vildmose, Holmegård Mose, Brandstrup Mose, Svanemose, Kongens Mose, Sølsted Mose, Horreby Lyng and Store Åmose. More peatland projects are planned, depending on funding opportunities. It is a challenge to restore mires in Denmark as the adjacent areas often are in agricultural use and intensively drained. Rewetting is therefore expensive, and large compensations are needed.

There is still a large potential for restoration of peatlands in Denmark. The presence of peat and peat forming conditions receive attention in a new financial assistance program to rewet carbon rich lowland soils in e.g. river valleys.

\subsubsection{Acknowledgements}

We thank Bent Østergaard and Mogens H. Greve for GIS data preparation and Steen Gyldenkærne for comments to an earlier draft of the Danish chapter.

\subsubsection{References}

Bou Kheir R., Greve M.H., Bøcher P.K., Greve M.B., Larsen R. \& McCloy K. (2010). Predictive mapping of soil organic carbon in wet cultivated lands using classification-tree based models: The case study of Denmark. Journal of Environmental Management 91: 1150-1160. http://dx.doi.org/10.1016/j.jenvman.2010.01.001

Dalgas E. (1876). Hede- Moser og Kjærjorde [Soils of Heathlands, bogs and fens]. Det Danske Hedeselskab., København, 103 p. (In Danish).

Dau J.H.C. (1829). Die Torfmoore Seelands. Gyldendal \& Heinrichs, Kopenhagen, Leipzig, $316 \mathrm{p}$.

Djurhuus S., Krogh L. \& Greve M.H. (2005). Estimates of the carbon stocks in Danish mires. Icelandic Agricultural Sciences 18: 11-20.

du Rietz G.E. (1949). Huvudenheter och huvudgränser i Svensk myrvegetation. Svensk Botanisk Tidsskrift 43: 274-309 (In Swedish).

Ejrnæs R. (2009). Notat til By og Landsskabsstyrelsen med udkast til Kapitel 1 til 4 landerapporten til CBD om tilstand, udvikling og trusler for Danmarks Biodiversitet (Draft for CBD on conditions, development and threats for the biodiversity of Denmark). University of Aarhus, National Environmental Research Institute.

Esri ArcGIS World Imagery. Source: Esri, DigitalGlobe, GeoEye, i-cubed, USDA, USGS, AEX, Getmapping, Aerogrid, IGN, IGP, swisstopo, and the GIS User Community. 
Greve M. H., Christensen O.F., Greve M.B. \& Bou Kheir R. (2014). Change in peat coverage in Danish cultivated soils during the past 35 years. Soil Science 179: 250-257. http://dx.doi.org/10.1097/SS.0000000000000066

Henriques T.S. \& Sharp P. (2014). The Danish agricultural revolution in an energy perspective: a case of development with few domestic energy sources. Discussion Papers on Business and Economics No. 9, Faculty of Business and Social Sciences, University of Southern Denmark, Odense, Denmark.

Hoffmann C.C. \& Baattrup-Pedersen A. (2007). Re-establishing freshwater wetlands in Denmark. Ecological Engineering 30: 157-166. http://dx.doi.org/10.1016/ j.ecoleng.2006.09.022

IPCC (2014). 2013 Supplement to the 2006 IPCC Guidelines for National Greenhouse Gas Inventories: Wetlands, Hiraishi T., Krug T., Tanabe K., Srivastava N., Baasansuren J., Fukuda M. \& Troxler T.G. (eds), Published by IPCC, Switzerland.

Jepsen M.R. \& Levin G. (2013). Semantically based reclassification of Danish land-use and land-cover information. International Journal of Geographical Information Science 27: 2375-2390. http://dx.doi.org/10.1080/ 13658816.2013 .803555

Klöve B., Marttila H., Óskarrson H., Grønlund A., Berglund K., Berglund Ö., Maljanen M. \& Lægdsmand M. (2009). Past and future of cultivated peatlands - Nordic environmental challenges. Peatlands International 2/2009: 28-32.

Levin G., Jepsen M.R. \& Blemmer M. (2012) Basemap. Technical documentation of a model for elaboration of land-use and land-cover map for Denmark. Aarhus University, DCE - Danish Centre for Environment and Energy, Technical Report from DCE No. 11, 47 pp. Available at: http://www.dmu.dk/Pub/TR11.pdf.

NIS Denmark (2014) Nielsen O.-K., Plejdrup M.S., Winther M., Nielsen M., Gyldenkærne S., Mikkelsen M.H., Albrektsen R., Thomsen M., Hjelgaard K., Hoffmann L., Fauser P., Bruun H.G., Johannsen V.K., Nord-Larsen T., Vesterdal L., Møller I.S., Caspersen O.H., Rasmussen E., Petersen S.B., Baunbæk L. \& Hansen M.G. (2014). Denmark's National Inventory Report 2014. Emission Inventories 1990-2012 Submitted under the United Nations Framework Convention on Climate Change and the Kyoto Protocol. Aarhus University, DCE - Danish Centre for Environment and Energy, 1214 pp. Scientific Report from DCE - Danish Centre for Environment and Energy. Available at: http://www.dce2.au.dk/pub/SR101.pdf.

Risager M., Aaby, B. \& Greve M.H. (2015). Denmark. In: Joosten H., Tanneberger F. \& Moen, A. (eds.), Mires and peatlands of Europe - Status, distribution, and nature conservation, Schweizerbart Science Publishers, Stuttgart, Germany. 


\subsection{Greenland}

\subsubsection{Characterization of the country}

Figure 1: NorBalWet countries covered in this report (grey); Greenland (dark grey)

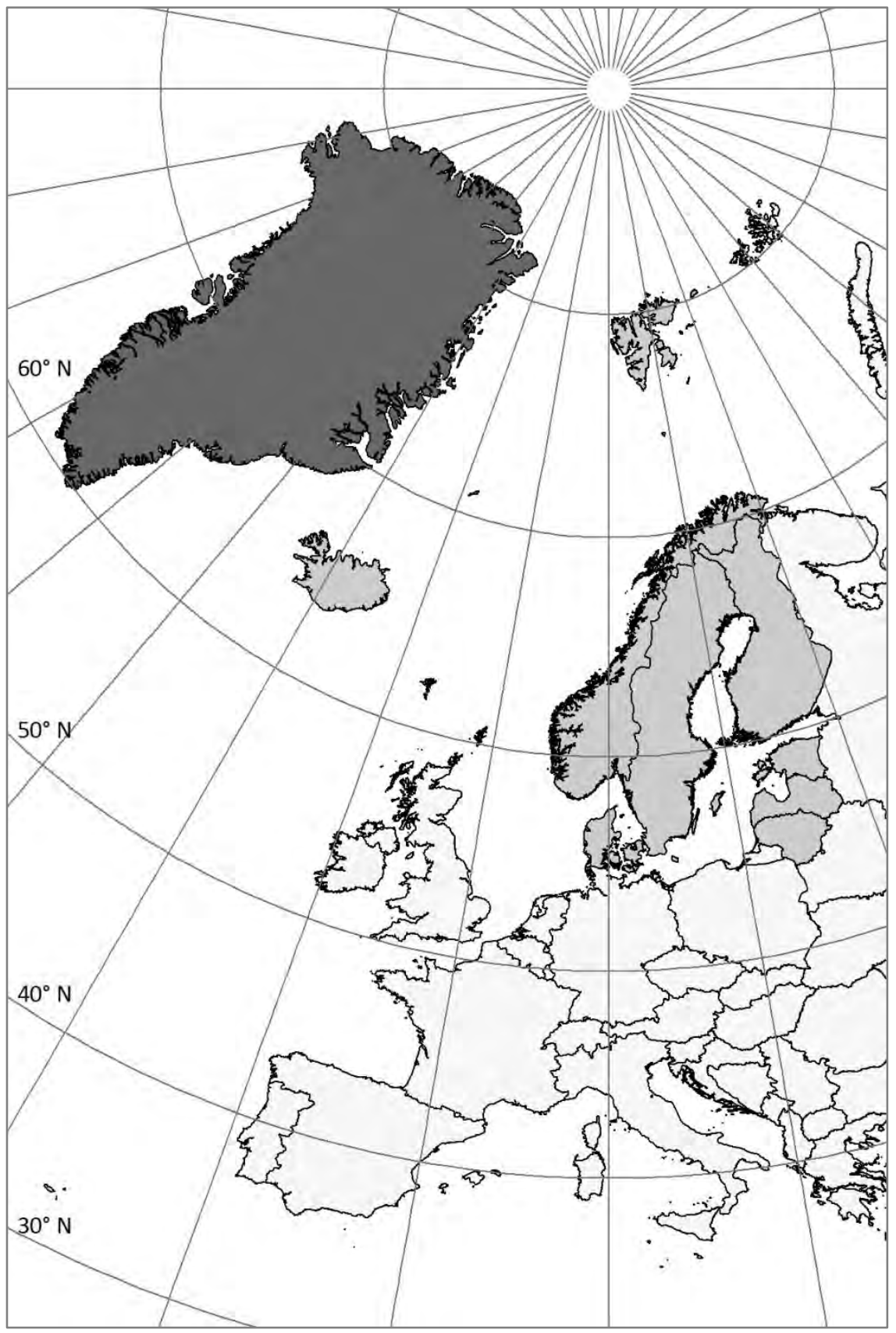


Greenland (Greenlandic: Kalaallit Nunaat) is situated on the North American continent between the Arctic Ocean and the North Atlantic Ocean, northeast of Canada and is the world's largest non-continental island. The country stretches from $59^{\circ}$ to $83^{\circ} \mathrm{N}$ and from $11^{\circ}$ to $74^{\circ} \mathrm{W}$ (Figure 1). Thus, the northernmost point of Greenland is located only $740 \mathrm{~km}$ from the North Pole, but the southernmost point, Cape Farewell, is at about the same latitude as Oslo in Norway. More than three-quarters of the island is covered by ice. The weight of this ice sheet has depressed the central land area to form a basin lying more than $300 \mathrm{~m}$ below sea level, while elevations rise suddenly and steeply near the coast. ${ }^{131}$

The climate in Greenland is arctic to subarctic with cold winters and cool summers, in which the mean temperature does normally not exceed $10^{\circ} \mathrm{C}$. Mean temperature averaged across the entire island is below -20 ${ }^{\circ} \mathrm{C}$ from November to April; then it rises to nearly $0{ }^{\circ} \mathrm{C}$ in July, but there are significant differences in temperatures. The coldest place in Greenland is the ice cap where temperatures are likely to fall below $-70{ }^{\circ} \mathrm{C}$. Mean temperatures in January 2013 were $-5.2^{\circ} \mathrm{C}$ in Nuuk and $-16.8^{\circ}$ in Kangerlussuaq, whereas in July 2013 they were $7.0^{\circ} \mathrm{C}$ and $11.2^{\circ} \mathrm{C}$, respectively. Foehn winds, which are common, can cause a temperature rise by $30{ }^{\circ} \mathrm{C}$ during winter. Due to the midnight sun of northern Greenland in summer, temperatures at the West and East coast of Greenland differ only a few degrees when moving from north to south. In winter, darkness and the absence of warm sea currents considerably prolong winter from South to North. In summer, drift ice and cold water along the coast result in colder fjords. In winter, the position close to open sea means that coastal areas are warmer. ${ }^{132}$

\subsubsection{Peatland diversity}

Due to the logistical difficulties to reach much of the land, information on the distribution of peatland vegetation and organic soils is still of a very general nature. Comprehensive data on the extent, distribution, ecology, and drainage status of peatlands/organic soils in Greenland seem not to be available. According to Glooschenko et al. (1993), wetlands in Greenland include shallow open water, saltmarshes, fens, and bogs. Due to the harsh Arctic climate and extremely low primary production, many peat

${ }^{131}$ Statistics Greenland (2014); http://en.wikipedia.org/wiki/Greenland\#Geography_and_climate
${ }^{132}$ Statistics Greenland (2014); http://www.dmi.dk/en/klima/klimaet-frem-til-i-dag/groenland/ 
occurrences will be rather shallow (peat thickness $<30 \mathrm{~cm}$ ). Peat covered areas predominantly occur close to the Arctic and the North Atlantic Ocean in low lying coastal environments. Glooschenko et al. (1993) distinguished several Arctic and Subarctic wetland regions for Canada and Greenland, of which five stretch into Greenland:

In the Low Subarctic Wetland Region the wetlands mainly consist of bogs and fens. In Greenland the Subarctic is restricted to the southwestern coastal part, generally south of Nuuk, where still remnants of the original tree vegetation occur. In this region permafrost is sporadic in wetlands. The summers are much cooler than on the North American continent and precipitation is moderate. Böcher (1938) mentioned the presence of "bogs". However, the dominant species Eriophorum scheuchzeri, Equisetum variegatum and Saxifraga hirculus indicate that these were fens, resembling the seepage fens common in the Low Arctic in Canada.

The Low Arctic Wetland Region covers only part of the southern coast of Greenland, where summer is cold to cool and little precipitation is received. Lowland polygon mires (low and high centre polygons), spring fens, and coastal marshes occur. Permafrost is present under all land surfaces, except close to lakes. The maximal thickness of peat in the peatlands of this region is approximately $1.5 \mathrm{~m}$ in high centre polygon mires and 50 $\mathrm{cm}$ in low centre polygon fens, but in Greenland this might be less.

The Mid-Arctic Wetland Region covers the coast of central Greenland. The climate is characterized by short cool summers, long cold winters, and very little precipitation. The most common wetlands are polygon fens, but also basin fens, small elevated peat mound bogs, low centre polygon bogs and coastal marshes occur. Permafrost is present under all land surfaces. Peat thickness is less than $150 \mathrm{~cm}$ in peat mounds and usually less than $50 \mathrm{~cm}$ in fens. Fen vegetation is dominated by Carex and Eriophorum, whereas the peat mounds are covered by lichens, Sphagnum mosses, ericaceous shrubs, and dwarf birch (Betula glandulosa). High centre polygons are commonly eroded by wind and are entirely devoid of vegetation. 
The High Arctic Wetland Region covers the northern coastal strip of Greenland and higher elevation areas below the glacial ice. The climate of this region is continental, characterized by short cool summers, long cold winters, and very little precipitation. Because of the aridity of the High Arctic, wetlands are scarce: they occur mainly in poorly drained lowlands and along the coastal lowlands. Wetland types include basin fens with or without lowland polygon development, peat mound bogs and coastal marshes. Peat thickness is in average $0.5 \mathrm{~m}$. Permafrost is present under all land surfaces.

Greenland has only a limited occurrence of Arctic salt marshes. They are restricted to protected coastal areas, such as the Disko area on the western coast (points "VII" in Figure 2). The marshes are characterized by turf-forming grass species. Dominant are the genera Puccinellia, Carex, Potentilla, and Stellaria. Arctic salt marshes occur either in distinct zones or, more commonly, as patches. Freshwater marshes may be present behind the salt marshes, with vegetation consisting of Carex, Equisetum, Polygonum, and Salix.

Figure 2 gives information on Ramsar sites, the distribution of Quaternary deposits (both may include peatlands/organic soils), and local peat occurrences as reported in scientific publications. 
Figure 2: Map of Greenland showing: a) RAMSAR sites that might host peatlands/organic soils (Arabic numbers and red solid lines, 133 after Egevang \& Boertmann 2001); b) Quaternary deposits (blue areas, after the Geological Map of Greenland(scale 1:2,500,000134,135) and c) peat occurrences according to literature (Roman numbers, see Table 2). Furthermore, national parks and protected areas are indicated by dotted lines or filled asterisks and by their name. Breeding reserves are shown by open asterisks

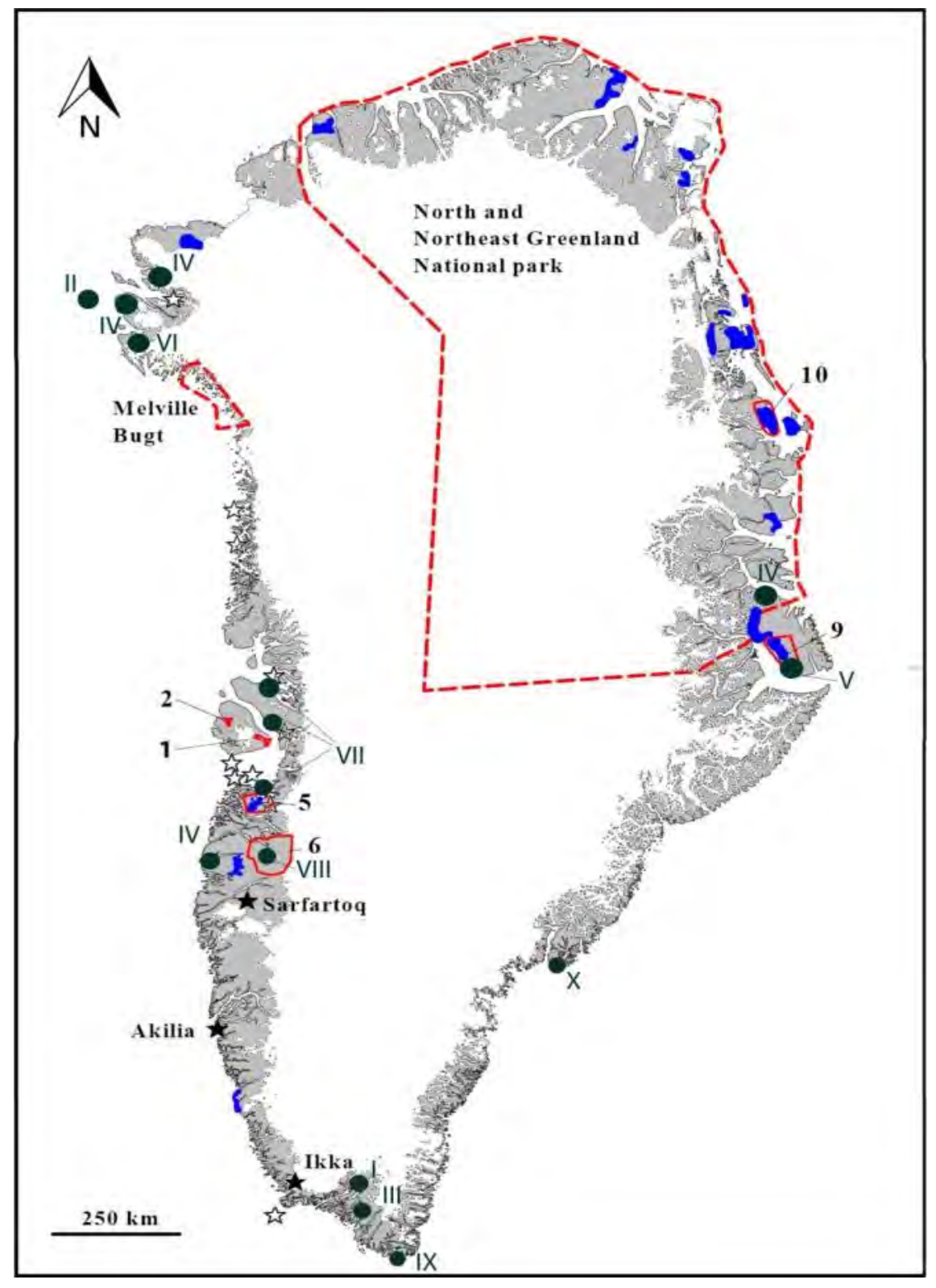

133 Details in Table 1

${ }^{134}$ Available at: http://www.geus.dk/program-areas/raw-materials-greenl-map/greenland/gr-map/kost_1uk.htm

${ }^{135}$ Available at: http://data.geus.dk/map2/geogreen/\#Z=7\&N=7944703\&E=37161 
Table 1: Overview of the Ramsar sites of Greenland: number, name, size and habitat distribution (after Egevang \& Boertmann 2001)

\begin{tabular}{|c|c|c|c|c|}
\hline No. & Name & $\begin{array}{r}\text { Size } \\
\left(10^{3} \mathrm{ha}\right)\end{array}$ & $\begin{array}{l}\text { Terrestrial/ } \\
\text { marine (\%) }\end{array}$ & $\begin{array}{l}\text { Habitats that may include } \\
\text { peatlands/organic soils }\end{array}$ \\
\hline 1 & $\begin{array}{l}\text { Aqajarua, Sullorsuaq and } \\
\text { Qaamassoq, Disko }\end{array}$ & 22.4 & $80 / 20$ & $\begin{array}{l}\text { Valley Sullorsuag and river delta (many } \\
\text { ponds, small lakes, extensive marshlands } \\
\text { and salt marshes) }\end{array}$ \\
\hline 2 & $\begin{array}{l}\text { Kangersooq and } \\
\text { Kuussuaq, Disko }\end{array}$ & 6.5 & $72 / 28$ & $\begin{array}{l}\text { Two broad glacial valleys with a variety of } \\
\text { wetlands (e.g. small ponds and extensive } \\
\text { moss-sedge marshes) }\end{array}$ \\
\hline 3 & $\begin{array}{l}\text { Kuannersuit Kuussat, } \\
\text { Disko }\end{array}$ & 5.2 & $100 / 0$ & $\begin{array}{l}\text { Probably no peatlands (not shown in } \\
\text { Figure 2). }\end{array}$ \\
\hline 4 & Kitsissunnguit & 6.9 & $12 / 88$ & $\begin{array}{l}\text { Probably no peatlands (not shown in } \\
\text { Figure 2). }\end{array}$ \\
\hline 5 & Naterneq & 184.0 & $84 / 16$ & $\begin{array}{l}\text { Marshes and fens along the many shallow } \\
\text { lakes, rivers and streams; vegetation } \\
\text { dominated by sedges, cotton grass and } \\
\text { mats of mosses. }\end{array}$ \\
\hline 6 & $\begin{array}{l}\text { Eqalummiut Nunaat and } \\
\text { Nassuttuup Nunaa }\end{array}$ & 579.5 & $95 / 5$ & $\begin{array}{l}\text { Wetlands, marshes, numerous lakes and } \\
\text { moss-mat communities (in the southern } \\
\text { part often seasonal dried out). }\end{array}$ \\
\hline 7 & $\begin{array}{l}\text { Ikkattoq and adjacent } \\
\text { archipelago }\end{array}$ & 44.9 & $50 / 50$ & $\begin{array}{l}\text { Probably no peatlands (not shown in } \\
\text { Figure 2). }\end{array}$ \\
\hline 8 & Kitsissut Avalliit & 4.5 & $4 / 96$ & $\begin{array}{l}\text { Probably no peatlands (not shown in } \\
\text { Figure 2). }\end{array}$ \\
\hline 9 & Heden & 252.4 & $95 / 5$ & $\begin{array}{l}\text { Marshes in the lower part, along rivers } \\
\text { and lake shores. The coast of the central } \\
\text { part has extensive saltmarshes. }\end{array}$ \\
\hline 10 & Hochstetter Forland & 184.8 & $93 / 7$ & $\begin{array}{l}\text { Extensive lowland area with grasslands, } \\
\text { marshes and numerous ponds. }\end{array}$ \\
\hline 11 & Kilen & 51.3 & $72 / 28$ & $\begin{array}{l}\text { Probably no peatlands (not shown in } \\
\text { Figure 2). }\end{array}$ \\
\hline
\end{tabular}




\begin{tabular}{|c|c|c|}
\hline Number & Location & Reference \\
\hline 1 & $61^{\circ} 11.506^{\prime} \mathrm{N} ; 45^{\circ} 33.075^{\prime} \mathrm{W}$ & Schoefield et al. 2008 \\
\hline \multirow[t]{2}{*}{$\|$} & $76^{\circ} 44.2580^{\prime} \mathrm{N} ; 73^{\circ} 12.4960^{\prime} \mathrm{W}$ & Bennike et al. 2008 \\
\hline & $76^{\circ} 43.6850^{\prime} \mathrm{N} ; 73^{\circ} 10.9700^{\prime} \mathrm{W}$ & Bennike et al. 2008 \\
\hline III & $60^{\circ} 46.115^{\prime} \mathrm{N} ; 45^{\circ} 34.961^{\prime} \mathrm{W}$ & Ledger et al. 2014 \\
\hline \multirow[t]{4}{*}{ IV } & $67^{\circ} 8.999^{\prime} \mathrm{N} ; 53^{\circ} 31.980^{\prime} \mathrm{W}$ & MacDonald et al. 2006 \\
\hline & $76^{\circ} 59.136 \mathrm{~N} ; 71^{\circ} 9.645^{\prime} \mathrm{W}$ & \\
\hline & $76^{\circ} 59.881^{\prime} \mathrm{N} ; 71^{\circ} 11.618^{\prime} \mathrm{W}$ & \\
\hline & $72^{\circ} 14.957^{\prime} \mathrm{N} ; 24^{\circ} 15.012^{\prime} \mathrm{W}$ & \\
\hline v & $70^{\circ} 50.6^{\prime} \mathrm{N} ; 24^{\circ} 00.5^{\prime} \mathrm{W}$ & Bennike et al. 1999 \\
\hline VI & $76^{\circ} \mathrm{N} ; 68^{\circ} \mathrm{W}$ (Thule Airbase area) & Burnham et al. 2010 \\
\hline VII & Several areas, no coordinates given. & Jensen 2006 \\
\hline VIII & $66^{\circ} 18.000^{\prime} \mathrm{N} 51^{\circ} 12.000^{\prime} \mathrm{W}$ & Ramsar 1996 \\
\hline IX & $59^{\circ} 46.755^{\prime} \mathrm{N} 43^{\circ} 54.692^{\prime} \mathrm{W}$ & Fredskild 1973 \\
\hline$x$ & $65^{\circ} 34.952^{\prime} \mathrm{N} 37^{\circ} 57.941^{\prime} \mathrm{W}$ & Bick 1978 \\
\hline
\end{tabular}

\subsubsection{Peatland degradation and threats}

Greenland has been settled by a succession of cultures from North America and Europe. The country has according to archaeological evidence been inhabited by humans from about 2,500 BC (Nielsen 2010). The Greenlandic settlers were also cutting peat and used it (together with stones) for building houses and walls (Jensen 2006). These "tørvemurshuse" were still used in the 20th century (Andersen 1976). The logistic difficulties and low population pressure have, however, restricted drainage and use of peatlands/organic soils to few places and small areas. Mining and mineral exploration have disturbed and destroyed local biota, also by pollution with e.g. heavy metals. Oil exploration may have some impact in future (Salathe 2009). The planned increase of mining activities in Greenland (currently about 70 exploration licences have been issued) will likely increasingly affect wetlands, including the existing Ramsar sites (Salathe 2009). Additionally, the increased warming of the arctic environment may enhance the "agricultural revolution" on Greenland with rising pressure on peatlands/organic soils to use them as drained grassland, cropland or for the extraction of peat for horticultural purposes (see also Results). 


\subsubsection{Current peatland: location, extent, status, land use and greenhouse gas emissions}

\section{Material and methods}

To assess the location and extent of peatlands and the land use applied, we used available information from the World Wide Web.

To assess the location and extent of of drained and used organic soils were extracted from NIS Denmark (2014).

The National Inventory Submission for Denmark (NIS Denmark 2014) to the Climate Convention UNFCCC provides information on the distribution and use of drained organic soils based on data from the Agricultural Advisory Service of the Ministry of Fisheries, Hunting and Agriculture of Greenland. The inventory for LULUCF and KP-LULUCF is carried out by the Danish Centre for Environment and Energy (DCE). The background data (area data and emission factors) for estimation of the Greenlandic emissions are collected by and stored in central databases at Statistics Greenland (NIS Denmark 2014).

Emission factors for drained organic soils for Arctic and Subarctic Climates are not covered by the Intergovernmental Panel on Climate Change (2014) guidance and do virtually not exist. Therefore, emissions were calculated using the (IPCC 2014) tier 1 default emission factors for $\mathrm{CO}_{2}$ for the Boreal climate/vegetation zone. We applied only half of these $\mathrm{CO}_{2}$ emission factors, considering the Arctic to Subarctic climate in Greenland.

Carbon loss from DOC (Dissolved Organic Carbon) is not included in this study.

\section{Results and discussion}

The National Inventory Submission (NIS ${ }^{136}$ Denmark 2014) reports 0.02 x $10^{3}$ ha of Forest Land on organic soil, ${ }^{137} 0.003 \times 10^{3}$ ha Cropland on drained organic soil, and $0.3 \times 10^{3}$ ha of Grassland on drained organic soil (Table 3; NIS Denmark 2014). Drainage and use of these areas lead, according to the NIS Denmark, to an annual $\mathrm{CO}_{2}$ emission of $0.0003 \mathrm{Mt}$. Recalculating these emissions using half of the latest emission factors for the Boreal climate/vegetation zone (IPCC 2014) increases the annual

\footnotetext{
136 The National Inventory Submission ('NIS') consists of the National Inventory Report ('NIR') and the Common Reporting Format ('CRF'). Since the NIR and the CRF were used, it will be referred below to the complete National Inventory Submission of Denmark (NIS Denmark 2014)

137 We assume that this Forest Land is managed and emissions should be reported.
} 
$\mathrm{CO}_{2}$ emissions to $0.002 \mathrm{Mt}$ (Table 3, see Material and Methods). Additionally, Greenland reported $7.2 \times 10^{3}$ ha of unmanaged Grassland on organic soil. Thus, the total reported organic soil area of Greenland is $7.5 \times 10^{3}$ ha (NIS Denmark 2014).

Fig. 3: Area of cultivated organic soils in Greenland (after NIS Denmark 2014)

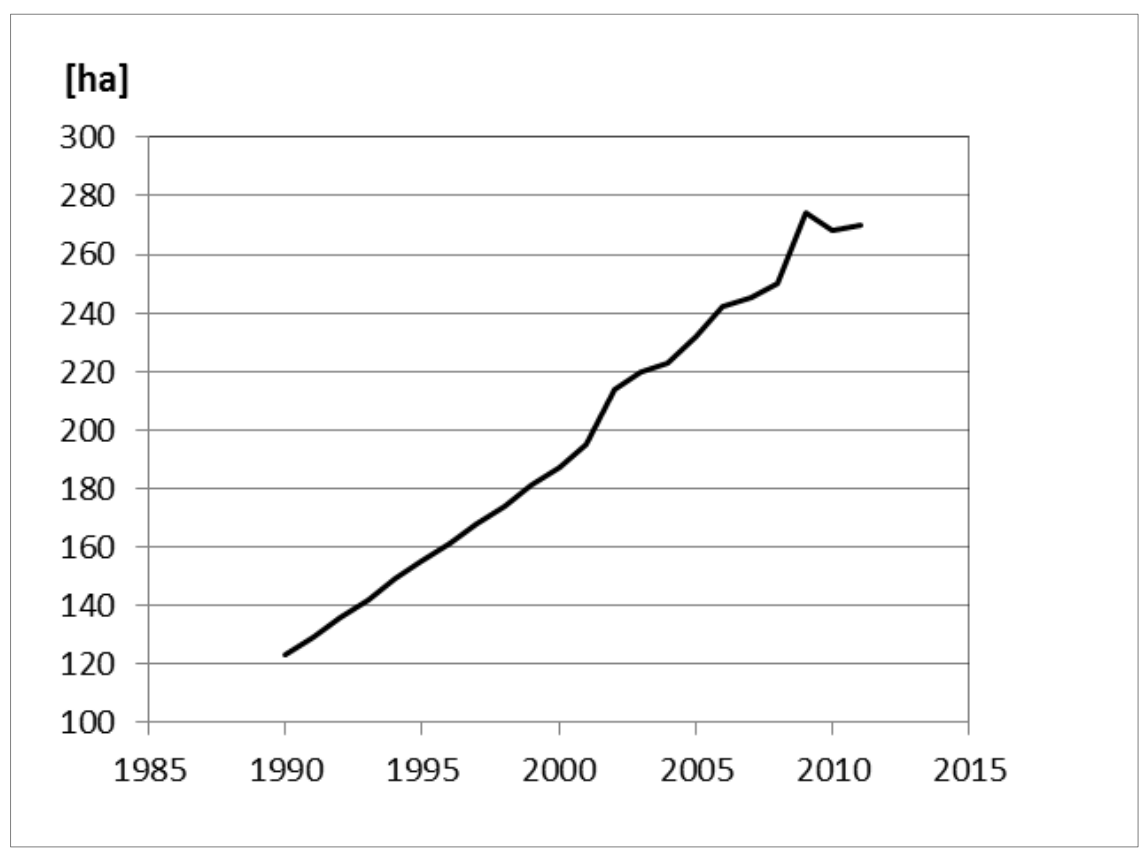

Recently, improved cultivation techniques and the use of fertilizers have led to an "agricultural revolution" in Greenland: increasing cropping and especially sheep farming. ${ }^{138}$ Climate change is prospected to lead to enhanced warming of the Subarctic and Arctic, which may facilitate this agricultural revolution. Also during the warmer parts of the Medieval Age clearing of pristine landscapes and extensive livestock breeding (overgrazing) took place in southwestern Greenland (Gauthier et al. 2010). As a result of the Viking presence, Anthrosols and heavily eroded landscapes are found in South and West Greenland. Since soil development on Greenland is generally poor ${ }^{139}$ and many areas are not suitable for agriculture, wetlands and organic soils could experience increasing land use pressure during the next, probably warmer decades. The area

138 http://www.nunalerineq.gl/english/landbrug/landbrug/index-landbrug.htm

139 http://eusoils.jrc.ec.europa.eu/library/maps/Circumpolar/download/130.pdf 
of cultivated organic soils (mostly Grassland) has actually already doubled since 1990 (Fig. 3). Currently, 50 farms are operating with agriculture as their primary source of income, based on sheep farming (with roughly 50,000 animals, sheep and lambs) and grazing during summer. In addition, there are small numbers of horses and cattle, and a few thousand tame reindeer. Winter fodder is grown on $1 \times 10^{3}$ ha, and potatoes and vegetables on a total of approximately $10 \mathrm{ha}^{7}$.

\subsubsection{Potential for conservation, restoration/ rehabilitation (including site examples)}

Considering the enhanced warming of the Arctic and Subarctic, the recent efforts undertaken by the authorities of Greenland to extent mining and oil exploitation and the expanding agriculture (see Results and discussion) it is advisable that Greenland increases its actions for wetland and peatland habitat protection.

\begin{tabular}{|c|c|c|c|c|c|}
\hline \multirow[t]{2}{*}{ GREENLAND } & \multicolumn{3}{|c|}{ National Inventory Report 2014} & \multicolumn{2}{|c|}{$\begin{array}{l}\text { Recalculated according to } \\
\text { IPCC } 2014\end{array}$} \\
\hline & $\begin{array}{r}\text { Area of } \\
\text { organic soil } \\
\left(10^{3} \text { ha }\right)\end{array}$ & $\begin{array}{r}\text { Net carbon } \\
\text { stock change } \\
\text { per area } \\
\left(\mathrm{t} \mathrm{CO}_{2} / \mathrm{ha} / \mathrm{yr}\right)\end{array}$ & $\begin{array}{r}\text { Emissions } \\
\left(\mathrm{Mt} \mathrm{CO}_{2} / \mathrm{yr}\right)\end{array}$ & $\begin{array}{r}\text { Net carbon } \\
\text { stock change } \\
\text { per area } \\
\left(\mathrm{t} \mathrm{CO}_{2} / \mathrm{ha} / \mathrm{yr}\right)\end{array}$ & $\begin{array}{r}\text { Emissions } \\
(\mathrm{Mt} \mathrm{CO} / \mathrm{yr})\end{array}$ \\
\hline \multicolumn{6}{|l|}{$\begin{array}{l}\text { Land Use Category } \\
\text { Forest Land remain- } \\
\text { ing Forest Land }\end{array}$} \\
\hline Other conifers ${ }^{1)}$ & 0.02 & $\begin{array}{l}\text { "not applica- } \\
\text { ble" }\end{array}$ & $\begin{array}{r}\text { "not } \\
\text { applicable" }\end{array}$ & 0.3 & 0.000 \\
\hline Qinngua Valley $^{21}$ & 0.01 & $\begin{array}{r}\text { "not applica- } \\
\text { ble" }\end{array}$ & $\begin{array}{r}\text { "not } \\
\text { applicable" }\end{array}$ & \pm 0 & \\
\hline$\sum$ FOREST LAND & 0.02 & & & & 0.000 \\
\hline $\begin{array}{l}\text { Grassland converted } \\
\text { to Cropland }\end{array}$ & 0.003 & 18.3 & 0.0000 & 13.7 & 0.000 \\
\hline$\Sigma C R O P L A N D$ & 0.003 & & 0.0000 & & 0.000 \\
\hline
\end{tabular}




\begin{tabular}{|c|c|c|c|c|c|}
\hline \multirow[t]{2}{*}{ GREENLAND } & \multicolumn{3}{|c|}{ National Inventory Report 2014} & \multicolumn{2}{|c|}{$\begin{array}{l}\text { Recalculated according to } \\
\text { IPCC } 2014\end{array}$} \\
\hline & $\begin{array}{r}\text { Area of } \\
\text { organic soil } \\
\left(10^{3} \mathrm{ha}\right)\end{array}$ & $\begin{array}{r}\text { Net carbon } \\
\text { stock change } \\
\text { per area } \\
\left(\mathrm{t} \mathrm{CO}_{2} / \mathrm{ha} / \mathrm{yr}\right)\end{array}$ & $\begin{array}{r}\text { Emissions } \\
(\mathrm{Mt} \mathrm{CO} / \mathrm{yr})\end{array}$ & $\begin{array}{r}\text { Net carbon } \\
\text { stock change } \\
\text { per area } \\
\left(\mathrm{t} \mathrm{CO}_{2} / \mathrm{ha} / \mathrm{yr}\right)\end{array}$ & $\begin{array}{r}\text { Emissions } \\
(\mathrm{Mt} \mathrm{CO} / \mathrm{yr})\end{array}$ \\
\hline \multicolumn{6}{|l|}{ Grassland remaining } \\
\hline Improved Grassland & 0.3 & 4.6 & 0.0012 & 9.2 & 0.002 \\
\hline $\begin{array}{l}\text { Unmanaged Grass- } \\
\text { land }\end{array}$ & 7.2 & \pm 0 & \pm 0 & \pm 0 & \\
\hline$\sum$ GRASSLAND & 0.3 & & 0.0012 & & 0.002 \\
\hline $\begin{array}{l}\sum \text { TOTAL PEATLAND } \\
\text { DRAINED }\end{array}$ & 0.3 & & 0.0012 & & 0.002 \\
\hline$\Sigma$ TOTAL PEATLAND & 7.5 & & & & \\
\hline
\end{tabular}

\footnotetext{
1) We assume that this Forest Land is managed and emissions should be reported.

2) "The Qinngua Valley is situated in a remote area. It consists of natural birch (Betula pubescens spp. czerepanovii and B. glandulosa) which develops to forest" (NIS Denmark, 2014)
}

The extent of peatlands with $>30 \mathrm{~cm}$ peat is unknown and might be small. But the extent of shallow organic soils ( $>10 \mathrm{~cm}$ over bedrock) might be considerably higher and is unknown too. These shallow organic soils are also covered by the IPCC and FAO definition of "organic soil" for which emissions must be separately reported to the UNFCCC.

Remote sensing based monitoring of ecosystems in Greenland (incl. "moist tundra", "fen" and "flooded grassland") is currently undertaken by the Institute of Geography at Copenhagen University. ${ }^{140}$

\subsubsection{Acknowledgements}

We thank Andreas Lysholt Mathiasen from the Department of Nature, Energy and Climate in the Ministry of Environment and Nature in Nuuk (Greenland) for his helpful comments on the draft version of this country chapter.

140 http://www.zackenberg.dk/fileadmin/Resources/DMU/GEM/Zackenberg/Nye_Zac_files/ GEM_part_B.pdf http://pure.au.dk/portal/en/publications/greenland-ecosystem-monitoring--strategy20102015\%283722b273-4c11-4328-829d-8834e6207a63\%29.html 


\subsubsection{References}

Andersen J. (1976). Selvbyggeri i Grønland. Tidsskriftet Grønland 5: 129-144.

Bennike O., Björck S., Böcher J., Hansen L., Heinemeier J. \& Wohlfarth B. (1999). Early Holocene plant and animal remains from North-east Greenland. Journal of Biogeography 26: 667-677.

Bennike O., Goodsite M. \& Heinemeier J. (2008). Palaeoecology of Holocene peat deposits from Nordvestø, north-west Greenland. J. Paleolimnol. 40: 557-565. http://dx.doi.org/10.1007/s10933-007-9181-3

Bick H. (1978). A Postglacial pollen diagram from Angmagssalik, East Greenland. Meddelelser om Grønland 204, 22 p.

Böcher T.W. (1938). Biological distributional types in the flora of Greenland. Meddelelser om Grønland 106, 336 p.

Burnham J.H. \& Sletten R.S. (2010). Spatial distribution of soil organic carbon in northwest Greenland and underestimates of high Arctic carbon stores. Global Biogeochemical Cycles 24: GB 3012, 14 p.

Egevang C. \& Boertmann D. (2001). The Greenland Ramsar sites, a status report. National Environmental Research Institute, Denmark, NERI Technical Report 346, 95 pp.

Fredskild B. (1973). Palaeobotanical investigations of some peat deposits of Norse age at Qagssiarssuk, South Greenland. Meddelelser om Grønland 204, 41 p.

Gauthier E., Bichet V., Massa C., Petit C., Vannière B. \& Richard H. (2010). Pollen and non-pollen palynomorph evidence of medieval farming activities in southwestern Greenland. Vegetation History and Archaeobotany 19: 427-438.

http://dx.doi.org/10.1007/s00334-010-0251-5

Glooschenko W.A., Tarnocai C., Zoltai S. \& Glooschenko V. (1993). Wetlands of Canada and Greenland. In: Whigham D., Dykyjova D. \& Hejny S. (eds.), Wetlands of the world - Inventory, ecology and management. Volume I. Handbook of vegetation science. Kluwer, Dordrecht, pp. 415-514.

IPCC (2014). 2014 Supplement to the 2006 IPCC Guidelines for National Greenhouse Gas Inventories: Wetlands, Hiraishi T., Krug T., Tanabe K., Srivastava N., Baasansuren J., Fukuda M. \& Troxler T.G. (eds), Published by IPCC, Switzerland.

Jensen J.F. (2006). The Stone Age of Qeqertarsuup Tunua (Disko Bugt). A regional analysis of the Saqqaq and Dorset cultures of Central West Greenland. Meddelelser om Grønland 32, 272 p.

Ledger P. M., Edwards K. J. \& Schofield J.E. (2014). Taphonomy or signal sensitivity in palaeoecological investigations of Norse landnám in Vatnahverfi, southern Greenland? Boreas 44: 197-215. http://dx.doi.org/10.1111/bor.12089

MacDonald G.M., Beilman D.W., Kremenetski K.V., Sheng Y., Smith L.C. \& Velichko A.A. (2006). Rapid early development of circumarctic peatlands and atmospheric $\mathrm{CH}_{4}$ and $\mathrm{CO}_{2}$ variations. Science 314: 285-288. http://dx.doi.org/10.1126/science.1131722

NIS Denmark (2014). Nielsen O.-K., Plejdrup M.S., Winther M., Nielsen M., Gyldenkærne S., Mikkelsen, M.H. Albrektsen R., Thomsen M., Hjelgaard K., Hoffmann L., Fauser P., Bruun H.G., Johannsen V.K., Nord-Larsen T., Vesterdal L., Møller I.S., Caspersen O.H., Rasmussen E., Petersen S.B., Baunbæ, L. \& Hansen M.G. (2014). Denmark's National Inventory Report 2014. Emission Inventories 1990-2012 Submitted under the United Nations Framework Convention on Climate Change and the Kyoto Protocol. Aarhus University, DCE - Danish Centre for Environment and Energy, 1214pp. Scientific Report from DCE - Danish Centre for Environment and Energy. http://www.dce2.au.dk/pub/SR101.pdf 
Ramsar (1996). A list of Ramsar Sites with significant peatland components. Available at: http://www.ramsar.org/about_peat_list.htm

Salathe T. (2009). Mission Report Ramsar in Greenland, 8-16 June 2009. Ramsar Advisory Mission No. 61, 18 p.

Schofield J.E., Edwards K.J. \& Christensen C. (2008). Environmental impacts around the time of Norse landna'm in the Qorlortoq valley, Eastern Settlement, Greenland. Journal of Archaeological Science 35: 1643-1657. http://dx.doi.org/10.1016/ j.jas.2007.11.004

Vahl B. \& Kleemann, N. (2014). Greenland in Figures. Statistics Greenland, 11th revised edition; available at: http://www.stat.gl/publ/kl/GF/2014/pdf/

Greenland\%20in\%20Figures\%202014.pdf 
Ved Stranden 18

DK-1061 Copenhagen K

www.norden.org

\section{Peatlands and Climate in a Ramsar context}

Peatlands in the Nordic Baltic region and elsewhere in the world store large amounts of carbon and are at the same time important for conservation of biodiversity. Thus peatlands are space-effective carbon stocks, but when drained carbon and nitrogen are released as greenhouse gases to the atmosphere and as nitrate to the surface water, while methane will be released when rewetting.

New knowledge reveals that one of the most efficient means to mitigate emissions of greenhouse gases to the atmosphere are the restoration of drained peatlands by reestablish former high water tables on organic soils.

This project on synergies between climate change mitigation and the restoration of peatlands has been conducted under a regional Ramsar initiative covering the Nordic and Baltic countries (NorBalWet), with support from the Nordic Council of Ministers. The report contains chapters on peatlands and their role in climate change mitigation, individual country chapters and the role of the Ramsar Convention.

TemaNord 2015:544

ISBN 978-92-893-4195-0 (PRINT)

ISBN 978-92-893-4196-7 (PDF)

ISBN 978-92-893-4197-4 (EPUB)

ISSN 0908-6692

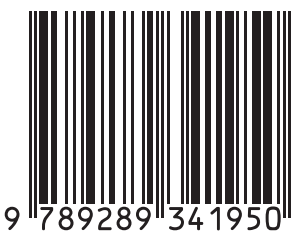

